CAROLINA SCHÄFFER FERREIRA JORGE

\title{
INTERPRETAÇÃO DAS IMUNIDADES DO ART. 150, VI, DA CONSTITUIÇÃO FEDERAL
}

Tese de Mestrado

Orientador: Professor Associado Dr. Estevão Horvath

UNIVERSIDADE DE SÃO PAULO

FACULDADE DE DIREITO

São Paulo - SP

2014 


\section{CAROLINA SCHÄFFER FERREIRA JORGE}

\section{INTERPRETAÇÃO DAS IMUNIDADES DO ART. 150, VI, DA CONSTITUIÇÃO FEDERAL}

Tese apresentada à Banca Examinadora do Programa de Pós-Graduação em Direito, da Faculdade de Direito da Universidade de São Paulo, como exigência parcial para obtenção do título de Mestre em Direito, na área de concentração Direito Tributário, sob a orientação do Professor Associado Dr. Estevão Horvath.

UNIVERSIDADE DE SÃO PAULO

FACULDADE DE DIREITO

São Paulo - SP

2014 
Jorge, Carolina Schäffer Ferreira.

Interpretação das Imunidades do Art. 150, VI, da Constituição Federal / Carolina Schäffer Ferreira Jorge - São Paulo, 2014.

$160 \mathrm{f}$.

Orientador: Professor Associado Dr. Estevão Horvath

Dissertação (Mestrado) - Faculdade de Direito da Universidade de São Paulo. 


\section{RESUMO}

Carolina Schäffer Ferreira Jorge. Interpretação das Imunidades do Art. 150, VI, da Constituição Federal. 160 f. Mestrado - Faculdade de Direito, Universidade de São Paulo, São Paulo, 2014. O presente trabalho examina a interpretação das imunidades tributárias previstas no art. 150, VI, da Constituição Federal brasileira de 1988. Em primeiro lugar, são examinadas as teorias sobre a interpretação jurídica e conclui-se que a interpretação deve ser entendida como a construção do sentido do texto. No entanto, tal interpretação está limitada ao "sentido literal possível" do texto e, ademais, deve ser devidamente fundamentada, através do discurso argumentativo, de modo que a decisão possa ser intersubjetivamente controlada. Conclui-se que, no ordenamento jurídico brasileiro, têm primazia os argumentos de natureza linguística e sistemática, visto que se referem diretamente à ordem jurídica vigente. E, dentre os argumentos sistemáticos, deve-se prestigiar aquele sentido que seja mais consentâneo com o princípio constitucional subjacente ao dispositivo a ser interpretado. As mesmas conclusões aplicam-se às normas de Direito Tributário, já que estão sujeitas aos mesmos métodos de interpretação aplicáveis às demais normas jurídicas. Contudo, deve ser ressaltado que as normas que estabelecem a incidência dos tributos, bem como os preceitos que fixam a competência, incluindo as imunidades, têm sua interpretação limitada ao sentido literal possível, sendo vedado o recurso à analogia. Diante disso, afirma-se que, na aplicação desses preceitos, devem ser considerados principalmente os argumentos linguísticos, que limitam a interpretação ao sentido possível do texto, e os argumentos sistemáticos, que estudam a relação das imunidades com as outras normas inseridas no ordenamento pátrio, especialmente os princípios constitucionais. Nesse estudo, deve ser examinada a função exercida pelas imunidades, que não apenas bloqueiam a instituição de tributos, como podem resguardar certas condutas e promover um estado de coisas desejado pelo Estado. Estabelecidas tais premissas, são examinadas as imunidades do art. 150, VI, da Constituição, tendo em vista as principais questões hoje debatidas pela doutrina e pela jurisprudência acerca desses preceitos.

Palavras-chave: Interpretação, Direito Tributário, Competência, Imunidades Tributárias. 


\begin{abstract}
Carolina Schäffer Ferreira Jorge. Interpretation of the Tax Immunities Provided for in Article 150, VI, of Brazilian Constitution. 160 p. Master. Faculty of Law, University of São Paulo, São Paulo, 2014. This thesis examines the interpretation of the tax immunities provided for in article 150, VI, of the Brazilian Constitution of 1988. Firstly, we will examine the main theories concerning juridical interpretation and we conclude that interpretation must be understood as the construction of the meaning of the text. However, the interpretation is limited to the "possible literal meaning" of the text and must also be fully justified, through an argumentative discourse, so that decisions can be controlled intersubjectivly. We conclude that, in light of Brazilian legal system, the linguistic and systematic arguments have precedence, since those arguments refer directly to the legal system now in force. Considering these systematic arguments, the interpreter should give precedence to the meaning that is more compatible with the principle underlying the provision subject to interpretation. The same conclusions apply to tax provisions, since they are subject to the same methods of interpretation applicable to other legal provisions. However, it should be stressed that the interpretation of provisions that regulate the incidence of taxes, as well as those that regulate taxation powers, including tax immunities, is limited to the possible literal meaning of the text, being forbidden the use of analogies. Therefore, in the interpretation of those provisions, we should consider mainly the linguistic arguments, which limit the interpretation to the possible meaning, and the systematic arguments, which study the relationship between tax immunities and other provisions of our legal system, especially the constitutional principles. In this study, it should be examined the functions performed by tax immunities, that not only prohibit taxation, but also can protect some types of conducts and promote a state of affairs desired by the State. Having established those premises, we examine the tax immunities provided for in article 150, VI, of Brazilian Constitution, in light of the main topics now debated by the literature and the case law concerning those provisions.
\end{abstract}

Keywords: Interpretation, Tax Law, Legal Powers, Tax Immunities. 
INTRODUÇÃ

CAPÍTULO 1: Imunidades Tributárias................................................................................ 3

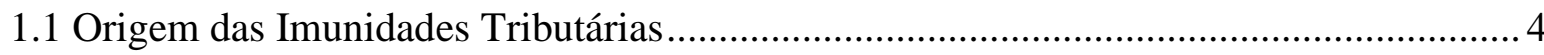

1.2 As Imunidades Tributárias nas Constituições Brasileiras............................................... 7

CAPITULO 2: O Conceito de Imunidade Tributária ............................................................. 10

2.1 Imunidades e as Limitações ao Poder de Tributar........................................................ 11

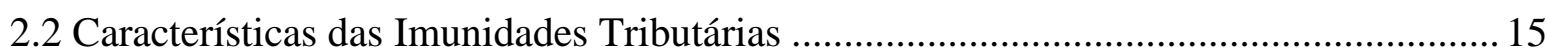

2.2.1 A imunidade é regra jurídica com sede constitucional....................................... 15

2.2.2 É delimitativa da competência e obsta o exercício da atividade legislativa na criação de tributos em relação a certos fatos especiais e determinados ............................ 17

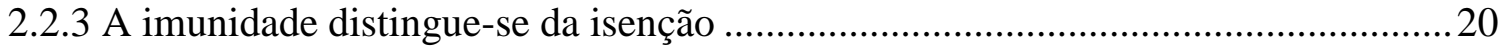

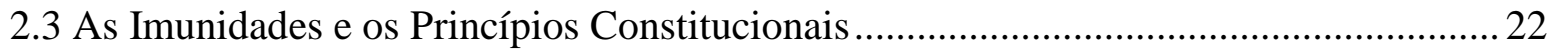

2.4 Classificações das Imunidades Tributárias .................................................................. 26

2.5 Tributos Abrangidos pelas Imunidades Tributárias .................................................... 29

CAPÍTULO 3: Interpretação das Imunidades Tributárias ......................................... 32

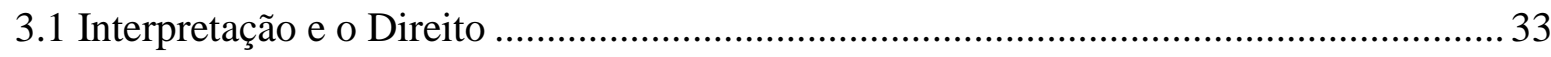

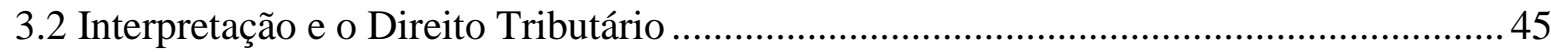

3.2.1 As teorias tradicionais sobre a interpretação do Direito Tributário.......................... 45

3.2.2 A interpretação no Direito Tributário Brasileiro .................................................... 49

3.3 Interpretação das Imunidades Tributárias ........................................................................ 58

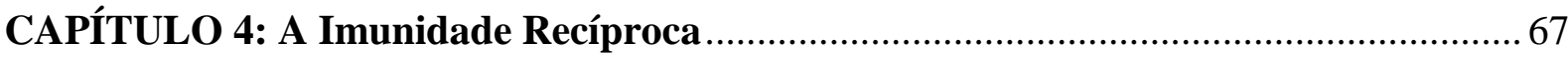

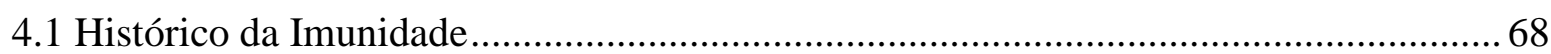

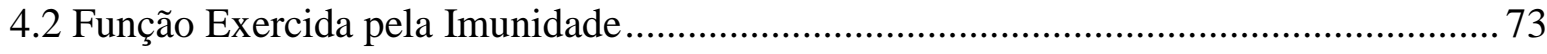

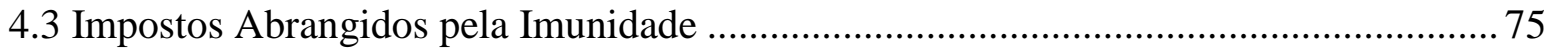

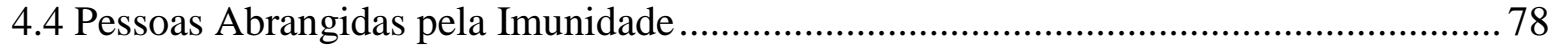

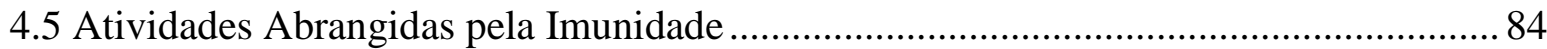


CAPÍtulo 5: As Imunidades dos Templos, Partidos Políticos, Entidades Sindicais dos Trabalhadores e Instituições de Educação e Assistência Social ...................................... 94

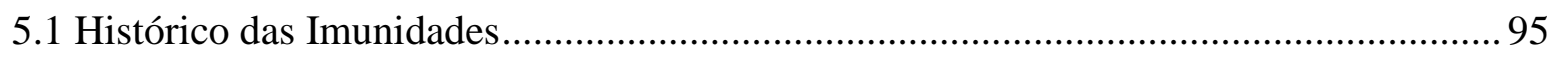

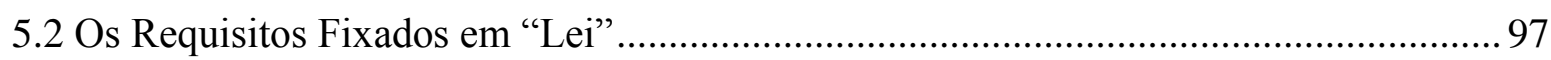

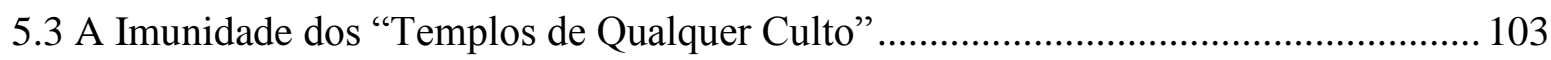

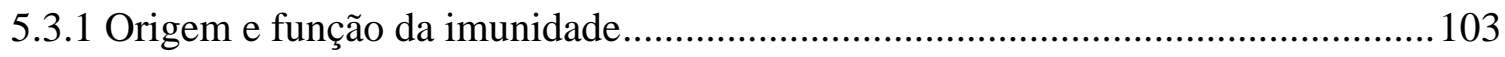

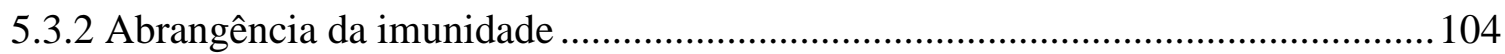

5.4 As Imunidades dos Partidos Políticos, das Entidades Sindicais dos Trabalhadores e das Instituições de Educação e Assistência Social ................................................................ 107

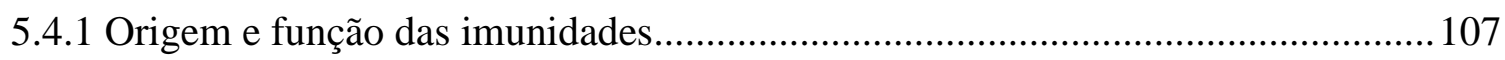

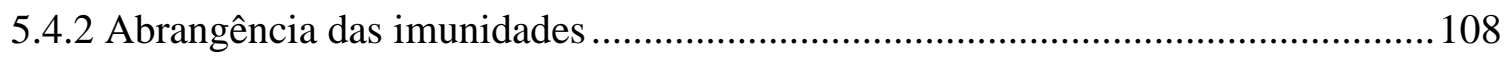

5.5 Interpretação do Art. 150, $\S 4^{\circ}$, da Constituição.......................................................... 110

CAPITUlO 6: As Imunidades dos Livros, Jornais e Periódicos e do Papel Destinado à

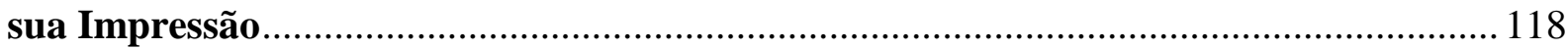

6.1 Histórico das Imunidades e sua Função....................................................................... 119

6.2 A Imunidade dos Livros, Jornais e Periódicos ........................................................ 121

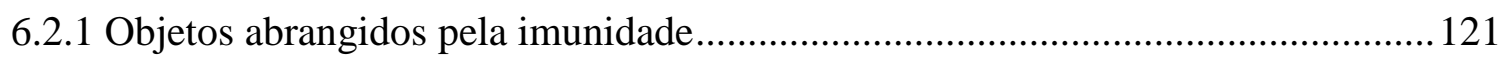

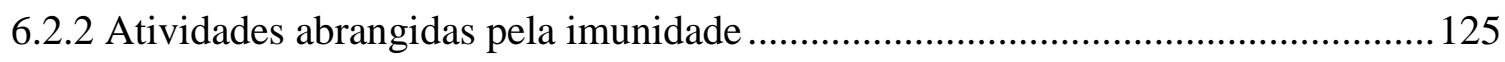

6.3 A Imunidade do Papel Destinado à Impressão ......................................................... 130

CAPÍTULO 7: A Imunidade dos Fonogramas e Videofonogramas ................................ 134

7.1 Histórico da Imunidade e sua Função ........................................................................... 135

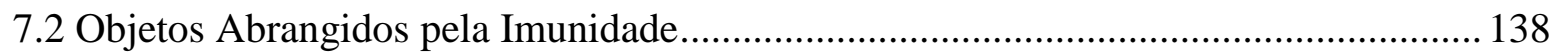

7.3 Atividades Abrangidas pela Imunidade ................................................................. 142

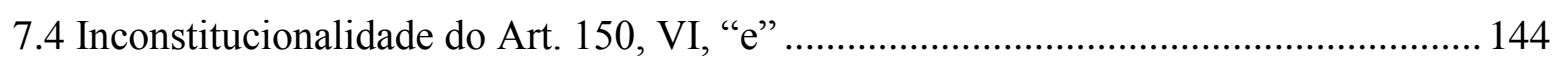

7.4.1 Inconstitucionalidade por violação à igualdade.................................................. 144

7.4.2 Inconstitucionalidade por ofensa ao regime tributário concedido à Zona Franca de

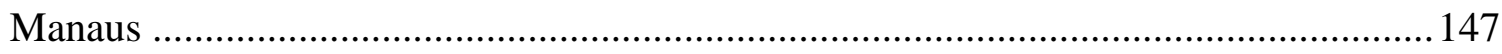

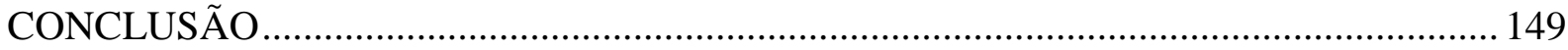

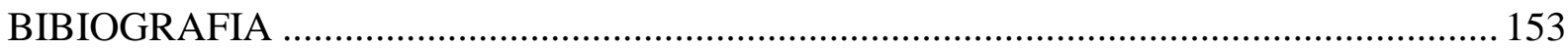




\section{INTRODUÇÃO}

A interpretação das imunidades tributárias previstas nas constituições brasileiras é um tema que sempre suscitou inúmeros questionamentos na doutrina e na jurisprudência.

Isso decorre, em primeiro lugar, da própria dificuldade de se definir o que é a interpretação jurídica e qual deve ser papel exercido pelo aplicador do Direito nesse processo. Com efeito, a interpretação pode ser vista como um mero ato de conhecimento, no qual o intérprete exerceria a função de revelar, trazer à tona, um sentido já imanente ao texto, pode ser vista como um ato de decisão, no qual o intérprete escolheria o sentido que quer ver atribuído ao texto, ou pode ser vista como um ato de conhecimento e também de decisão.

A escolha de uma das concepções acima tem importância fundamental na definição dos limites da interpretação e na escolha de um método adequado para a realização do trabalho interpretativo, impactando assim profundamente a aplicação de cada preceito.

Mas não é só isso. $\mathrm{O}$ exame das imunidades exige também que se defina se os limites e os métodos de interpretação escolhidos são aplicáveis à interpretação dos preceitos de Direito Tributário e, especialmente, aos enunciados de Direito Constitucional Tributário ou se há alguma particularidade que determine uma interpretação específica desses dispositivos.

Como veremos no curso deste trabalho, a adoção de premissas teóricas distintas acerca da interpretação jurídica e, particularmente, da interpretação do Direito Tributário é responsável por muitas das controvérsias hoje existentes em matéria de imunidades.

Por fim, é preciso examinar as peculiaridades dos enunciados que veiculam regras imunitórias, bem como a sua relação com os princípios consagrados pela Constituição.

Com efeito, não se pode ignorar a íntima relação existente entre as imunidades e importantes princípios constitucionais, como a liberdade religiosa, a liberdade de organização partidária e sindical, a livre manifestação do pensamento, dentre outros. Assim, definir de que forma essa relação impactará a aplicação desses preceitos é essencial para que sejam estabelecidas as premissas teóricas para a interpretação das regras de imunidade tributária.

Sendo assim, o propósito do presente trabalho é analisar a interpretação das imunidades tributárias e, em especial, a interpretação dos preceitos inseridos no art. 150, VI, da Constituição brasileira de 1988, os quais consagram a chamada "imunidade recíproca", a imunidade dos templos de qualquer culto, dos partidos políticos, das entidades sindicais dos trabalhadores, das instituições de educação e de assistência social, dos livros, jornais e periódicos e do papel destinado à sua impressão e dos fonogramas e videofonogramas. 
Tais imunidades foram escolhidas para ser o objeto do nosso estudo em virtude da sua importância no ordenamento jurídico brasileiro e também em razão da sua abrangência, tendo em vista que alcançam diversos impostos e abrangem inúmeras pessoas, situações e objetos, dando origem assim a algumas das principais discussões sobre essa matéria.

Nesse ensejo, iremos analisar, antes de tudo, as principais teorias desenvolvidas acerca da interpretação jurídica e seus reflexos na interpretação dos preceitos de Direito Tributário. A partir disso, estabeleceremos nossas premissas teóricas para a interpretação das imunidades tributárias previstas no art. 150, VI, da Constituição Federal de 1988.

Estabelecidas tais premissas, passaremos então a examinar as principais questões hoje debatidas acerca da aplicação desses preceitos, confrontando nossas conclusões com as reflexões produzidas pela doutrina e com as decisões proferidas pelo Supremo Tribunal Federal sobre o tema. Vale ressaltar que este trabalho não pretende esgotar o estudo de todas as questões relativas às imunidades do art. 150, mas fornecer critérios para a interpretação desses preceitos, aplicando-os ao estudo de problemas hoje centrais no exame da matéria. 
1. Imunidades Tributárias. 


\subsection{Origem das Imunidades Tributárias.}

Leciona SELIGMAN que o termo imunidade origina-se do latim immunitas, que corresponde à ideia de liberação do munus ${ }^{1}$. Munus, por sua vez, é aquilo que provém de uma autoridade pública ou da lei, isto é, equivale a um encargo público. Desse modo, nas palavras de BERnARdo RibeIRo DE Moraes, o termo imunidade traduzia a noção de "um privilégio concedido a alguma pessoa de não ser obrigada a determinado encargo ou ônus"”2.

O termo immunitas já era empregado no Império Romano para fazer referência à desoneração tributária. Com efeito, já naquela época havia uma preocupação com o ônus gerado pelos tributos e com a necessidade de eximir certas pessoas do seu pagamento ${ }^{3}$.

Em Roma, a população estava sujeita a dois tipos de tributo: o chamado tributo do cidadão e o tributo das províncias. O tributo dos cidadãos era cobrado de todos os cidadãos romanos em virtude de determinadas situações excepcionais, tais como a necessidade de custear as despesas da guerra, de modo que não era um tributo ordinário. Por sua vez, o tributo provincial era cobrado das províncias sujeitas, visto que o vencedor nas guerras tributava os perdedores. Assim é que o tributo ordinário das províncias trazia consigo o estigma da servidão. Esse fato, aliado à arbitrariedade dos métodos de arrecadação utilizados pelo Fisco, fez com que o tributo provincial fosse considerado verdadeiramente odioso ${ }^{4}$.

A mesma percepção podia ser encontrada na Grécia antiga, onde os tributos ordinários também eram associados à tirania e à servidão. Em virtude desses fatores, tanto na Grécia quanto em Roma, foram concedidas imunidades às pessoas dos cidadãos, desonerando-os do pagamento dos tributos ordinários, como um reflexo da sua liberdade ${ }^{5}$.

As imunidades em questão foram mantidas até a época imperial, quando o Imperador Augusto criou um tributo ordinário cobrado dos cidadãos romanos. Porém, como ressalta SCHOUERI, até Diocleciano e Justiniano sobreviveram algumas imunidades tributárias, tais como as imunidades dos impostos territoriais do solo itálico e da propriedade quiritária ${ }^{6}$.

\footnotetext{
${ }^{11}$ SELIGMAN, Edwin R. A. The Income Tax: a study of the history, theory and practice of income taxation at home and abroad. Nova Iorque: Macmillan, 1911, pp. 25 e 26.

${ }^{2}$ MORAES, Bernardo Ribeiro de. A Imunidade Tributária e Seus Novos Aspectos. In: MARTINS, Ives Gandra da Silva (coord.). Imunidades Tributárias. São Paulo: Revista dos Tribunais: Centro de Extensão Universitária, 1998, p. 105.

${ }^{3}$ SELIGMAN, Edwin R. A. The Income Tax, pp. 25 e 26.

${ }^{4}$ Veja nesse sentido VANONI, Ezio. Natureza e Interpretação das Leis Tributárias. Tradução de Rubens Gomes de Sousa. Rio de Janeiro: Edições Financeiras S/A, s/d, pp. 17 e ss.

${ }^{5}$ VANONI, Ezio. Natureza e Interpretação das Leis Tributárias, pp. 17 e ss.

${ }^{6}$ SCHOUERI, Luís Eduardo. Direito Tributário. São Paulo: Saraiva, 2011, p. 375.
} 
No início da Idade Média, os senhores feudais e a Igreja católica também estavam desonerados do pagamento de tributos, embora, para RICARDO LOBO TORRES, não se possa falar aí propriamente em "imunidades tributárias", uma vez que a Igreja e o senhorio não estavam subordinados ao poder real, mas constituíam "fontes autônomas de fiscalidade"7.

Por sua vez, nos séculos XIII a XIX, em virtude do colapso do feudalismo, as imunidades tributárias passaram a funcionar como uma forma de limitação do poder real frente à nobreza e à Igreja católica. Ensina RICARDO LOBO TORRES que, naquela época, proibia-se a tributação do senhorio e da Igreja em homenagem aos direitos preexistentes à organização estatal e à transferência do poder fiscal dos estamentos para o Rei ${ }^{8}$.

Vale ressaltar que na concepção então adotada a única religião beneficiada pela imunidade era a católica. Contudo, tal concepção passou por transformações com o advento do liberalismo, verificando-se uma progressiva extensão da imunidade a todos os cultos.

Após as grandes revoluções do século XVIII, consolidou-se o Estado de Direito e, nesse contexto, as imunidades perderam o seu caráter de privilégio voltado à nobreza e à Igreja e passaram a ser vistas como uma forma de limitação do poder tributário em favor das liberdades do cidadão. Assim, as imunidades passaram a ser associadas à democracia e à necessidade de se prestigiarem valores caros à sociedade, tais como a liberdade e a igualdade, entendimento que permanece até os dias atuais, em que as imunidades tributárias são associadas a valores como a liberdade religiosa, a livre manifestação do pensamento, a liberdade de organização partidária e sindical, dentre outros ${ }^{9}$.

Ademais, as imunidades deixaram de favorecer aqueles que possuíam maior capacidade contributiva e passaram a ser utilizadas como instrumento para reduzir a carga tributária daqueles que possuíam menor capacidade para contribuir para os gastos coletivos. Nesse contexto, ganham força as imunidades das instituições de caridade e de educação, com fundamento na ideia de que tais entidades já realizam funções de interesse público e, portanto, não podem ser obrigadas a contribuir ainda mais para o Estado por meio de tributos ${ }^{10}$.

Como veremos nos capítulos a seguir, essa nova visão das imunidades tributárias, que abandona a ideia de privilégio e as encara como um instrumento para a garantia e a

\footnotetext{
7 TORRES, Ricardo Lobo. Tratado de Direito Constitucional Financeiro e Tributário. Vol. III. Os Direitos Humanos e a Tributação: Imunidades e Isonomia. $3^{\mathrm{a}}$ ed. Rio de Janeiro: Renovar, 2005, p. 42.

${ }^{8}$ Ibidem, pp. 42-43.

${ }^{9}$ Ibidem, p. 43.

${ }^{10}$ SELIGMAN, Edwin R. A. The Income Tax, pp. 25 e 26.
} 
promoção de valores essenciais à sociedade, terá importantes reflexos na construção de uma teoria sobre a interpretação desses preceitos alinhada com o Texto Constitucional brasileiro. 


\subsection{As Imunidades Tributárias nas Constituições Brasileiras.}

A Constituição Federal de 1891 foi a primeira constituição brasileira a consagrar expressamente em seu texto regras de imunidade tributária. No entanto, a Carta de 1824 já retratava as transformações ocorridas no Direito Tributário nos últimos séculos e assim buscava abolir os privilégios e garantir a igualdade no que diz respeito à incidência tributária.

Assim, previa o seu art. 179 que ninguém seria isento de contribuir para as despesas do Estado na proporção dos seus haveres (inciso XV) e que estavam abolidos todos os privilégios que não fossem essenciais e inteiramente ligados aos cargos por utilidade pública (inciso XVI). Note-se que a Constituição reconheceu a legitimidade dos privilégios “essenciais" e voltados à "utilidade pública”, afastando desse modo os privilégios odiosos.

Pois bem. A Constituição brasileira de 1891 consagrou pela primeira vez em nossa história regras de imunidade tributária, instituindo, em seu art. 10, a chamada "imunidade recíproca", segundo a qual os Estados estavam proibidos de tributar bens e rendas federais e serviços a cargo da União e reciprocamente. Veja-se que, naquela época, a imunidade recíproca abrangia apenas os Estados e a União, não alcançando os Municípios.

A Carta de 1891 também proibiu a tributação da produção dos outros Estados pelo Estado por onde fossem exportadas $\left(\operatorname{art} .9^{\circ}, \S 2^{\circ}\right)$ e vedou aos Estados e à União a criação de impostos sobre o trânsito de produtos (art. 11, I), bem como o estabelecimento, a subvenção e o embaraço do exercício de cultos religiosos (art. 11, II). Essa última previsão pode ser considerada o embrião para a futura criação da imunidade tributária dos templos religiosos.

A Constituição de 1934 manteve a imunidade recíproca, porém a estendeu também aos Municípios e às concessões de serviços públicos (conforme art. 17, X). Foi reiterada a proibição de subvenção ou embaraço ao exercício dos cultos religiosos (art. 17, II e III), sem que, no entanto, houvesse sido criada uma imunidade específica para esse fim.

Ademais, a Carta Magna proibiu a tributação dos combustíveis produzidos no país para motores de explosão (art. 17, VIII) e dos estabelecimentos particulares de educação, gratuita primária ou profissional (art. 154) e determinou que nenhum imposto gravaria diretamente a profissão de escritor, jornalista ou professor (art. 113, item 36).

A Constituição de 1937 trouxe poucos dispositivos sobre as imunidades tributárias. Manteve a imunidade recíproca, ressaltando que os serviços públicos concedidos não gozariam do benefício (impropriamente denominado de "isenção") e que eventual isenção 
poderia ser outorgada a esses serviços no interesse comum por lei especial (art. 32, "c" e parágrafo único). Ademais, determinou que os Estados, o Distrito Federal e os Municípios não poderiam tributar, direta ou indiretamente, a produção, o comércio, a distribuição e a exportação de carvão mineral nacional e dos combustíveis e lubrificantes líquidos de qualquer origem (art. 35, “d”, na redação dada pela Lei Constitucional n 3/1940).

Já a Carta de 1946 ampliou consideravelmente o rol das imunidades tributárias então previstas pela Constituição, consagrando a imunidade recíproca (art. 31, V, "a"), a imunidade dos templos de qualquer culto e dos bens e serviços de partidos políticos, instituições de educação e de assistência social, desde que as suas rendas fossem aplicadas integralmente no país para os respectivos fins (art. 31, V, "b") e a imunidade do papel destinado exclusivamente à impressão de jornais, periódicos e livros (art. 31, V, “c").

A Constituição também vedou a instituição de impostos sobre o consumo de artigos que a lei classificasse como o mínimo indispensável à habitação, ao vestuário, à alimentação e ao tratamento médico das pessoas de restrita capacidade econômica (art. 15, § $1^{\circ}$ ) e a instituição de impostos sobre os direitos do autor e sobre a remuneração de professores e jornalistas, excetuando-se dessa desoneração os chamados impostos gerais (art. 203) ${ }^{11}$.

Com a edição da Emenda Constitucional no 10/1964, foi instituída a imunidade para os casos de desapropriação de imóvel rural no que tange aos impostos federais, estaduais e municipais incidentes sobre a transferência da propriedade desapropriada (art. 147, § $6^{\circ}$ ).

Por sua vez, com a Emenda Constitucional no 18/1965, responsável por uma expressiva reforma do sistema tributário brasileiro, foram reiteradas a imunidade recíproca, a imunidade dos templos de qualquer culto, a imunidade dos partidos políticos e de instituições de educação e assistência social e a imunidade do papel destinado à impressão de jornais, periódicos e livros. Também foi introduzida a previsão do art. $2^{\circ}, \S 1^{\circ}$, segundo a qual a imunidade recíproca abrangeria também as autarquias, no que diz respeito ao patrimônio, à renda e aos serviços vinculados às suas finalidades essenciais ou delas decorrentes.

A Carta de 1967 reiterou as imunidades já previstas no regime anterior, acrescentando a imunidade tributária dos livros, jornais e periódicos (art. 20, “d”). A Emenda Constitucional $\mathrm{n}^{\circ}$ 1/1969 manteve essa disciplina, acrescentando outras desonerações tributárias, relativas à extração, produção, circulação e consumo de lubrificantes e combustíveis líquidos ou gasosos, de energia elétrica e de minerais (art. 21, VIII e IX), às

\footnotetext{
${ }^{11}$ Inicialmente, tal desoneração era mais ampla, abrangendo todos os impostos incidentes sobre os direitos do autor e sobre a remuneração de professores e jornalistas. Com a edição da Emenda Constitucional nº 9/1964, foram excetuados os impostos gerais.
} 
pequenas glebas rurais (art. 21, § $6^{\circ}$ ), à transmissão de bens ou direitos incorporados ao patrimônio de pessoa jurídica em realização de capital e à transmissão de bens ou direitos decorrentes de fusão, incorporação ou extinção de capital de pessoa jurídica (art. $23, \S 3^{\circ}$ ) e às operações que destinassem ao exterior produtos industrializados (art. 23, $\S 7^{\circ}$ ).

Por fim, a Constituição de 1988 reproduziu as imunidades já consagradas na Emenda Constitucional $n^{\circ}$ 1/1969 e acrescentou a imunidade das fundações dos partidos políticos e das entidades sindicais dos trabalhadores, bem como esclareceu que as instituições de educação e assistência social não poderiam ter finalidade lucrativa (art. 150, VI, “c”).

A Carta também estabeleceu que a imunidade recíproca seria extensível às fundações instituídas e mantidas pelo Poder Público e que tal desoneração não poderia ser aplicada ao patrimônio, à renda e aos serviços relacionados com a exploração de atividades econômicas regidas pelas normas aplicáveis a empreendimentos privados ou em que houvesse contraprestação ou pagamento de preços ou tarifas pelo usuário (art. $150, \S \S 2^{\circ}$ e $3^{\circ}$ ).

Outrossim, a Constituição previu a imunidade das entidades beneficentes de assistência social no que tange às contribuições para a Seguridade Social (art. 195, § $7^{\circ}$ ), a imunidade das exportações e das receitas delas decorrentes (arts. 149, $\S 2^{\circ}, 153, \S 3^{\circ}$, III, e 155, X, “a"), a imunidade do ouro (art. 155, X, "c") e a imunidade das operações relativas a energia elétrica, serviços de telecomunicações e derivados de petróleo, combustíveis e minerais (art. 155, X, "b" e “d”, § $3^{\circ}$ ).

Recentemente, com a edição da Emenda Constitucional no 75/2013, foi instituída uma nova imunidade, relativa aos fonogramas e videofonogramas musicais produzidos no Brasil, que contenham obras musicais ou literomusicais de autores brasileiros e/ou obras em geral interpretadas por artistas brasileiros, tendo sido ressalvada da desoneração tributária a etapa de replicação industrial de mídias ópticas de leitura a laser (art. 150, VI, “e”).

Como se pode ver, houve um progressivo incremento das imunidades tributárias consagradas nas Constituições Federais brasileiras, o qual coincide com a tendência nacional de conferir um tratamento cada vez mais extenso e minucioso à matéria tributária. É o que também conclui REGINA HelenA Costa, para quem houve uma valorização do instrumento de desoneração da imunidade, em conformidade com a noção de que certas pessoas, bens e situações deveriam receber um tratamento diferenciado, tendo em vista a sua relevância para a sociedade e para a proteção de valores caros à população, afastando-se assim a tributação ${ }^{12}$.

\footnotetext{
12 COSTA, Regina Helena. Imunidades Tributárias: Teoria e análise da jurisprudência do STF. São Paulo: Malheiros, 2001, p. 31.
} 
2. O Conceito de Imunidade Tributária. 


\subsection{Imunidades e as Limitações ao Poder de Tributar.}

O estudo das imunidades tributárias deve passar, primeiramente, por uma análise do poder de tributar e dos limites impostos pelo Direito ao exercício desse poder.

O poder tributário pode ser definido como a faculdade ou a possibilidade jurídica de instituir e arrecadar tributos ${ }^{13}$. Como leciona SOUTO MAIOR BORGES, o poder tributário é um poder jurídico, de modo que o seu exercício deve ser regulado e limitado pelo Direito.

Assim, a Constituição pode estabelecer restrições às atividades do Legislativo, especificando a forma como este deverá legislar e também excluindo certas matérias do âmbito da sua competência, estabelecendo as chamadas "limitações de conteúdo"14.

Diante disso, é possível falar em limites formais e limites materiais ${ }^{15}$.

Os limites formais são aqueles que regulam a competência para criar normas jurídicas e o procedimento pelo qual tal competência será exercida. São exemplos de limitações formais em matéria tributária o princípio da legalidade, que determina a instituição dos tributos por meio de lei, e os princípios da anterioridade e da irretroatividade, os quais condicionam a eficácia das normas jurídicas ao transcurso de determinado período de tempo.

Por sua vez, as limitações materiais são aquelas que limitam ou predeterminam o conteúdo de uma norma futura. Tais normas podem determinar o objeto da disciplina de outras normas (isto é, quais hipóteses serão referidas pela norma) ou o modo como se dará essa disciplina (isto é, quais consequências jurídicas serão atribuídas àquelas hipóteses). No caso das limitações ao poder de tributar, leciona ÁvILA, tais normas determinam "o que” pode ser objeto de uma relação obrigacional tributária e "o que" pode ser objeto de fiscalização ${ }^{16}$.

É interessante observar que o conceito de limitações ao poder (e, consequentemente, de limitações ao poder de tributar) traz consigo alguns paradoxos ${ }^{17}$.

\footnotetext{
13 A definição é trazida por BORGES, Souto Maior. Teoria Geral da Isenção Tributária. $3^{\mathrm{a}}$ ed. São Paulo: Malheiros, 2011, pp. 25-26.

14 HART, Herbert L. A. O Conceito de Direito. Tradução de Antônio de Oliveira Sette-Câmara. São Paulo: Martins Fontes, 2009, pp. 90-91. Leciona o autor que, quando a Constituição estabelece tais limitações de conteúdo, ela não impõe ao Poder Legislativo propriamente um dever de não legislar de determinada maneira. Ela determina que qualquer legislação nesse sentido será nula. Desse modo, a limitação de conteúdo impõe uma "inabilitação jurídica" (legal disability), isto é, implica a ausência de poder jurídico para legislar sobre determinado tema.

${ }^{15}$ GUASTINI, Riccardo. Teoria e Dogmatica delle Fonti. Milão: A. Giuffrè, 1998, pp. 43-44.

${ }^{16}$ ÁVILA, Humberto. Sistema Constitucional Tributário. $5^{\mathrm{a}}$ ed. São Paulo: Saraiva, 2012, p. 71.

17 Tais paradoxos são ressaltados por ÁVILA, Humberto. Sistema Constitucional Tributário, pp. 125-126.
} 
Isso porque, embora restrinjam o poder estatal, as limitações devem ser reconhecidas por este mesmo poder para que possam ser aplicadas, tendo em vista que a limitação muitas vezes só se torna efetiva quando há instrumentos normativos para realizá-la.

Ademais, as limitações se opõem ao poder estatal, mas servem também para criar esse mesmo poder. A esse respeito, Ávila cita o caso do princípio democrático, que funciona como limitação ao poder, mas também como instrumento para a participação no poder estatal.

Por fim, as limitações são elas mesmas limitadas, eis que devem ser aplicadas em conjunto com outras normas do ordenamento. Assim, a título de exemplo, a legalidade é limitada pela regra que autoriza a alteração das alíquotas de certos impostos por ato do Poder Executivo, a imunidade recíproca é limitada pelo princípio da livre concorrência etc.

Pois bem. Como observado no capítulo anterior, a Constituição brasileira de 1988 trouxe inúmeros dispositivos sobre a matéria tributária. De fato, a ordem jurídica brasileira é verdadeiramente sui generis nessa questão, eis que regulamenta de maneira detalhada como se dará a instituição de tributos pelos entes federados. É o que salienta a doutrina pátria ${ }^{18}$ :

\begin{abstract}
O estudo de Direito Comparado oferece-nos material valioso para percebermos aspectos da fisionomia peculiar do nosso sistema constitucional tributário. Enquanto os sistemas de outros países de cultura ocidental pouco se demoraram nesse campo, cingindo-se a um número reduzido de disposições, que ferem tão-somente pontos essenciais, deixando à atividade legislativa infraconstitucional a grande tarefa de modelar o conjunto, o nosso, pelo contrário, foi abundante, dispensando à matéria tributária farta messe de preceitos, que dão pouca mobilidade ao legislador ordinário, em termos de exercitar seu gênio criativo.
\end{abstract}

A Constituição brasileira também se caracteriza pela sua notável rigidez, visto que requer um processo especial para a sua alteração, conforme previsto pelo art. 60. Esse fator, aliado ao detalhamento trazido pela Carta em matéria tributária, deu origem a um sistema constitucional tributário rígido, como bem ressaltou GERALDO ATALIBA, que pôs em destaque a posição particularíssima em que se encontra o sistema tributário brasileiro, eis que na Constituição já foi delineado o perfil dos tributos atribuídos aos entes federados ${ }^{19}$.

Assim, nos seus arts. 145 e 146, a Constituição trouxe as espécies tributárias e disciplinou a matéria reservada à lei complementar, nos arts. 148, 149, 153 e 154 dispôs sobre os tributos que podem ser instituídos pela União, no art. 155 dispôs sobre os tributos dos Estados e do Distrito Federal e no art. 156 disciplinou os tributos dos Municípios.

\footnotetext{
${ }^{18}$ CARVAlHO, Paulo de Barros. Curso de Direito Tributário. 21ª ed. São Paulo: Saraiva, 2009, pp. 157-158.

19 ATALIBA, Geraldo. Sistema Constitucional Tributário Brasileiro. São Paulo: Revista dos Tribunais, 1968, pp. 22 e ss.
} 
Tais dispositivos são um importante instrumento para distribuir competências legislativas aos entes federados e, dessa forma, contribuir para a garantia do pacto federativo, adotado pela Constituição de 1988 como cláusula pétrea, como dispõe o seu art. 60, §4 ${ }^{\circ}$ I.

É o que também salienta ESTEVÃo HoRVATH, para quem a repartição das competências assume especial relevância na manutenção do federalismo, eis que as receitas provenientes de tributos são a mais importante fonte de recursos para o Poder Público ${ }^{20}$.

O Texto Constitucional também traz uma seção intitulada "Das Limitações ao Poder de Tributar”. Nessa seção, encontram-se vários dispositivos de distinta natureza, tais como: (i) a proibição de exigência de tributo sem lei que o estabeleça; (ii) a proibição de instituição de tratamento desigual entre contribuintes que se encontrem em situação equivalente; (iii) a vedação à cobrança de tributos em relação a fatos geradores ocorridos antes do início da vigência da lei que os houver instituído ou aumentado; e (iv) a vedação à utilização do tributo com efeito de confisco. No entanto, não obstante as diferenças existentes entre esses preceitos, todos limitam de certa forma o poder de tributar dos entes da Federação.

Também nessa seção foram incluídas algumas hipóteses de imunidades tributárias, as quais estão previstas no art. 150, VI, da Constituição, que assim prescreve:

Art. 150. Sem prejuízo de outras garantias asseguradas ao contribuinte, é vedado à União, aos Estados, ao Distrito Federal e aos Municípios:

(...)

VI - instituir impostos sobre:

a) patrimônio, renda ou serviços, uns dos outros;

b) templos de qualquer culto;

c) patrimônio, renda ou serviços dos partidos políticos, inclusive suas fundações, das entidades sindicais dos trabalhadores, das instituições de educação e de assistência social, sem fins lucrativos, atendidos os requisitos da lei;

d) livros, jornais, periódicos e o papel destinado a sua impressão.

e) fonogramas e videofonogramas musicais produzidos no Brasil contendo obras musicais ou literomusicais de autores brasileiros e/ou obras em geral interpretadas por artistas brasileiros bem como os suportes materiais ou arquivos digitais que os contenham, salvo na etapa de replicação industrial de mídias ópticas de leitura a laser. (Incluída pela Emenda Constitucional n 75 , de 15.10.2013)

(...)

$\S 2^{\mathbf{o}}$ - A vedação do inciso VI, "a", é extensiva às autarquias e às fundações instituídas e mantidas pelo Poder Público, no que se refere ao patrimônio, à renda e aos serviços, vinculados a suas finalidades essenciais ou às delas decorrentes.

$\S 3^{\circ}$ - As vedações do inciso VI, "a", e do parágrafo anterior não se aplicam ao patrimônio, à renda e aos serviços, relacionados com exploração de atividades econômicas regidas pelas normas aplicáveis a empreendimentos privados, ou em que haja contraprestação ou pagamento de preços ou tarifas pelo usuário, nem exonera o promitente comprador da obrigação de pagar imposto relativamente ao bem imóvel.

${ }^{20}$ HORVATH, Estevão. Contribuições de Intervenção no Domínio Econômico. São Paulo: Dialética, 2009 , p. 11. 
$\S 4^{\circ}$ - As vedações expressas no inciso VI, alíneas "b" e "c", compreendem somente o patrimônio, a renda e os serviços, relacionados com as finalidades essenciais das entidades nelas mencionadas. (...)

Considerando a distinção entre limites formais e materiais exposta acima, os preceitos contidos no art. 150, VI, da Carta podem ser enquadrados como limitações materiais ao poder de tributar, visto que determinam o conteúdo da norma tributária a ser editada pelos entes federados, impedindo a instituição de impostos sobre determinados objetos e pessoas.

Logo, as imunidades tributárias podem ser definidas como limitações materiais ao poder de tributar. Contudo, tal definição não esgota o seu conceito, eis que, para a sua caracterização, é necessário que estejam presentes outros requisitos que passaremos a analisar. 


\subsection{Características das Imunidades Tributárias.}

Como visto acima, as imunidades tributárias limitam o poder de tributar dos entes federados. No entanto, elas possuem características próprias que as distinguem de outras limitações, tais como os princípios da legalidade, da anterioridade e do não confisco.

De acordo com MisABEL DERZI, as imunidades diferenciam-se dos princípios aludidos na medida em que estes regulamentam o bom exercício da competência tributária, ao passo que as imunidades retiram a competência para tributar certos objetos e pessoas ${ }^{21}$.

Ensina a autora que a imunidade tributária:

1. É regra jurídica, com sede constitucional;

2. É delimitativa (no sentido negativo) da competência dos entes políticos da Federação, ou regra de incompetência;

3. Obsta o exercício da atividade legislativa do ente estatal, pois nega competência para criar imposição em relação a certos fatos especiais e determinados;

4. Distingue-se da isenção, que se dá no plano infraconstitucional da lei ordinária ou complementar ${ }^{22}$.

Analisemos cada um dos itens expostos acima.

\subsubsection{A imunidade é regra jurídica com sede constitucional.}

As imunidades não são princípios, mas regras jurídicas ${ }^{23}$.

Ademais, trata-se de regras constitucionais, eis que, no sistema tributário brasileiro, apenas a Constituição pode traçar o limite da competência dos entes federados.

\footnotetext{
${ }^{21}$ DERZI, Misabel. Nota de atualização a BALEEIRO, Aliomar. Limitações Constitucionais ao Poder de Tributar. $8^{\text {a }}$ ed. Rio de Janeiro: Forense, 2010, p. 379.

22 Ibidem, p. 372.

${ }^{23}$ Empregamos o termo "regra" na acepção exposta por ÁVILA. Para esse autor, os princípios e as regras se diferenciam de acordo com três critérios: (i) a natureza da descrição normativa, eis que as regras descrevem certos objetos determináveis, tais como condutas, sujeitos ou matérias, ao passo que os princípios descrevem um estado ideal de coisas a ser buscado; (ii) a natureza da justificação, já que as regras exigem que seja feita uma análise da correspondência entre a descrição normativa e os fatos ocorridos, ao passo que os princípios demandam o exame da correlação positiva entre os efeitos da conduta e o estado de coisas a ser buscado; e (iii) a natureza da contribuição, já que as regras têm "pretensão de decidibilidade", buscando proporcionar uma solução para um problema já antecipado, ao passo que os princípios têm "pretensão de complementariedade", já que funcionam como razões a serem utilizadas, ao lado de outras, para a obtenção de uma decisão (in Teoria dos Princípios: da definição à aplicação dos princípios jurídicos. $5^{\mathrm{a}}$ ed. São Paulo: Malheiros, 2006, pp. 83-84).
} 
Com efeito, já lecionava AliOMAR BALEEIRo que as imunidades destacam-se pelo seu caráter político e são "disposições da lei maior que vedam ao legislador ordinário decretar impostos sobre certas pessoas, matérias ou fatos, enfim, situações que define" 24 .

GERALDO ATALIBA também salientava a necessidade de consagração constitucional das imunidades tributárias, afirmando que a "imunidade é ontologicamente constitucional" e só "a soberana Assembléia Constituinte pode estabelecer limitações e condições do exercício do poder tributário" ${ }^{25}$. No mesmo sentido AMÍlCAR DE ARAúJO FALCÃO, para quem a imunidade só se configura quando estabelecida na Constituição ${ }^{26}$.

Esse entendimento tem sido seguido pela doutrina majoritária brasileira, que ressalta a característica das imunidades como regras inseridas no Texto Constitucional ${ }^{27}$.

Em sentido contrário vale mencionar o escólio de RICARDO LOBO TORRES, para quem a imunidade tributária é "uma relação jurídica que instrumentaliza os direitos fundamentais ou uma qualidade da pessoa que lhe embasa o direito público subjetivo à nãoincidência tributária ou uma exteriorização dos direitos da liberdade que provoca a incompetência tributária do ente público" 28 . Para o autor, a imunidade é uma limitação absoluta do poder tributário do Estado pelas liberdades preexistentes, é a "não incidência ditada pelos direitos humanos e absolutos que são anteriores ao pacto constitucional" 29 .

Bem por isso, para LOBO TORRES, a imunidade pode existir ainda que não haja declaração expressa na Constituição. Por outro lado, para o autor, a mera intributabilidade proclamada pela Constituição não corresponde a uma verdadeira imunidade quando estiver fundada em questões de justiça ou de utilidade, e não em direitos fundamentais, como ocorreria nas hipóteses da imunidade dos jornais e livros, da energia elétrica, dentre outras.

\footnotetext{
${ }^{24}$ BALEEIRO, Aliomar. Uma Introdução à Ciência das Finanças. 17a ed. Rio de Janeiro: Forense, 2010, p. 374.

${ }^{25}$ ATALIBA, Geraldo. Natureza Jurídica da Contribuição de Melhoria. São Paulo: Revista dos Tribunais, 1964, p. 231.

${ }^{26}$ FALCÃO, Amílcar de Araújo. Imunidade e Isenção Tributária - Instituição de Assistência Social. Revista de Direito Administrativo, vol. 66, 1961, p. 368.

${ }^{27}$ MORAES, Bernardo Ribeiro de. Doutrina e Prática do Impôsto de Indústrias e Profissões. Tomo II. São Paulo: Max Limonad, 1964, pp. 652-653; OLIVEIRA, Yonne Dolácio de. As imunidades genéricas. In: NOGUEIRA, Ruy Barbosa (org.). Estudos Tributários em Homenagem à Memória de Rubens Gomes de Sousa. São Paulo: Resenha Tributária, 1974, p. 488; NOGUEIRA, Ruy Barbosa. Imunidades. $2^{a}$ ed. São Paulo: Saraiva, 1992, pp. 22-23; DENARI, Zelmo. Curso de Direito Tributário. $6^{\mathrm{a}}$ ed. Rio de Janeiro: Forense, 1998, p. 154; MEIRELLES, Hely Lopes. Direito Municipal Brasileiro. 17a ed. São Paulo: Malheiros, 2013, p. 194; COÊLHO, Sacha Calmon Navarro. Comentários à Constituição de 1988. $9^{\mathrm{a}}$ ed. Rio de Janeiro: Forense, 2005, p. 312. Afirma esse último que "a imunidade é congênita à Constituição, sua sede é inelutavelmente constitucional".

${ }^{28}$ TORRES, Ricardo Lobo. Tratado de Direito Constitucional Financeiro e Tributário, pp. 44-45.

${ }^{29}$ Ibidem, p. 59.
} 
Embora concordemos com o autor quando salienta a íntima relação existente entre as imunidades tributárias e os direitos fundamentais, discordamos da sua definição do instituto como "limitação absoluta do poder tributário pelas liberdades preexistentes".

Isso porque, para nós, não há direitos humanos anteriores à Constituição (isto é, liberdades preexistentes), que possam ser reconhecidos independentemente da sua positivação na ordem jurídica. Entendemos que os direitos fundamentais são aqueles efetivamente previstos, positivados, no ordenamento jurídico brasileiro, de forma expressa ou implícita.

Sendo assim, se não há liberdades preexistentes e anteriores à Constituição, não podemos conceituar as imunidades como a limitação do poder ditada por tais liberdades.

Ante o exposto, entendemos que, para a caracterização de uma imunidade tributária, é essencial que o preceito seja uma regra e esteja inserido no Texto Constitucional.

\subsection{2. É delimitativa da competência e obsta o exercício da atividade} legislativa na criação de tributos em relação a certos fatos especiais e determinados.

A imunidade não é apenas uma regra jurídica com sede constitucional, mas uma regra jurídica voltada à delimitação da competência tributária dos entes federados.

PONTES DE MIRANDA define imunidade como "regra jurídica no plano das regras jurídicas de competência dos poderes públicos" que "obsta à atividade legislativa impositiva, retira ao corpo, que cria impostos, qualquer competência para os pôr, na espécie" $30 \_31$.

De fato, a competência tributária dos entes federados é definida pela conjugação de normas que atribuem (positivamente) poder para instituir tributos e normas que retiram tal poder no que toca a determinadas pessoas ou objetos - as chamadas imunidades tributárias.

Através da atuação conjunta dessas normas são traçados os limites da competência tributária, entendida como uma das parcelas legiferantes de que são dotadas as

\footnotetext{
${ }^{30}$ MIRANDA, Pontes. Comentários à Constituição de 1967. Tomo II. São Paulo: Revista dos Tribunais, 1967, p. 392.

31 A relação entre as imunidades e a competência tributária é ressaltada por grande parte da doutrina. Veja-se nesse sentido OLIVEIRA, Yonne Dolácio de. As imunidades genéricas, p. 461; CARRAZZA, Roque Antonio. A Imunidade Tributária das Empresas Estatais Delegatárias de Serviços Públicos: Um estudo sobre a imunidade tributária da Empresa Brasileira de Correios e Telégrafos - ECT. São Paulo: Malheiros, 2004, p. 20; MORAES, Bernardo Ribeiro de. A Imunidade Tributária e seus Novos Aspectos. Revista Dialética de Direito Tributário, no 34, 1998, pp. 28 e ss.; NOGUEIRA, Ruy Barbosa. Imunidades, pp. 22-23; MACHADO, Hugo de Brito. Curso de Direito Tributário, 33ª ed. São Paulo: Malheiros, 2012, pp. 287-288, dentre outros.
} 
pessoas políticas, consubstanciada na faculdade de inovar no ordenamento através da produção de normas jurídicas sobre tributos, como define PAULO DE BARROS CARVALHO ${ }^{32}$.

É importante salientar, no entanto, que não há uma cronologia entre a atribuição de poder tributário e o seu posterior mutilo pelas regras de imunidade. A relação entre as normas que atribuem poder e as normas de imunidade não é cronológica, mas sim lógica. Desse modo, todas elas agem simultaneamente no desenho das competências tributárias.

Inclusive por essa razão, autores como PAULO DE BARROS CARVALHO ${ }^{33}$ criticam a definição das imunidades tributárias como limitações ao poder de tributar ou como limitação às competências tributárias, tendo em vista que ela induz ao entendimento de que seria primeiramente outorgada competência às pessoas políticas de Direito Público e, posteriormente, tal competência seria restringida por meio das regras de imunidade.

De fato, tal não ocorre.

Como salientam Geraldo AtAliba e Aires F. BARREto ${ }^{34}$, a competência tributária já surge com campo definitivo, demarcado pelos contornos resultantes da ação e reação de normas que atribuem o poder para instituir tributos e normas que o retiram. No dizer de SOUTO MAIOR BORGES, a competência já nasce constitucionalmente limitada ${ }^{35}$.

No entanto, a ideia de limitação no estudo das imunidades é relevante na medida em que é capaz de distinguir de forma mais clara as imunidades tributárias das hipóteses de mera incompetência que pode ser deduzida de dispositivos constitucionais. Veja, a título de exemplo, o caso dos Municípios, que não podem tributar a circulação de mercadorias, ou o caso da União, que não pode tributar a prestação de serviços ou a doação de bens. Nessas hipóteses, estamos tratando de fatos que não foram inseridos na competência tributária dos Municípios e da União, embora não se possa falar propriamente em imunidade tributária.

Assim, a imunidade é distinta eis que ela efetivamente atua em conjugação com outra regra que atribui poderes para tributar, delimitando a sua extensão. Dessa forma é que as imunidades, como aduz MiSABEL DERZI ${ }^{36}$, são um non sense quando analisadas isoladamente, uma vez que só adquirem sentido quando são colocadas em confronto com outras normas ${ }^{37}$.

\footnotetext{
${ }^{32}$ CARVAlHO, Paulo de Barros. Direito Tributário: Linguagem e Método. $4^{\mathrm{a}}$ ed. São Paulo: Noeses, 2011, p. 240.

${ }^{33}$ CARVAlHO, Paulo de Barros. Direito Tributário: Linguagem e Método, pp. 338 e ss.

34 ATALIBA, Geraldo e BARRETO, Aires Fernandino. Imposto sobre Serviços. Tributação de anúncios e destaques em listas ou guias telefônicos. Inadmissibilidade em face de vedação constitucional. Revista de Direito Tributário, v. 11, nº 39, 1987, p. 106.

35 BORGES, José Souto Maior. Teoria Geral da Isenção Tributária, p. 217.

${ }^{36}$ DERZI, Misabel. Limitações Constitucionais ao Poder de Tributar, nota de atualização, pp. 376-378.

${ }^{37}$ No mesmo sentido ÁVILA, Humberto. Sistema Constitucional Tributário, p. 134.
} 
A imunidade é, portanto, uma das múltiplas formas de demarcação da competência, caracterizando-se pela circunstância de a delimitar negativamente ${ }^{38}$.

Tendo em vista que a imunidade é uma regra de competência, também não nos parece adequado defini-la como hipótese de não-incidência constitucionalmente qualificada.

Esse tipo de definição pode ser encontrado em autores como SoUTO MAIOR BORGES, para quem haveria duas modalidades de não-incidência: a não-incidência genérica ou pura e simples e a não-incidência juridicamente qualificada ou especial, que corresponderia a não-incidência por determinação da Constituição, da lei ordinária ou de lei complementar. Para o autor, a imunidade tributária deveria ser enquadrada na segunda categoria, sendo assim uma hipótese de não-incidência constitucionalmente qualificada ${ }^{39}$.

Parece-nos que tal definição não retrata de forma adequada as imunidades tributárias, uma vez que tais dispositivos não fazem referência direta ao fenômeno da incidência, mas são regras de competência voltadas às pessoas políticas de Direito Público.

No entanto, é importante salientar que, embora SOUTO MAIOR faça uso dessa definição, ele também ressalta a estreita relação entre a imunidade e a competência tributária, afirmando que a primeira está no plano das regras de competência ou, mais precisamente, das regras negativas de competência e "porque a regra jurídica de imunidade é uma limitação constitucional ao poder de tributar deve ser conceituada como regra de exclusão ou restrição de competência tributária e não apenas de proibição de incidência do preceito que tributa" 40 .

Diante do exposto, a definição de MiSABEL DERZI é precisa ao conceituar a imunidade tributária como "regra constitucional expressa (ou implicitamente necessária), que estabelece a não competência das pessoas políticas da federação para tributar certos fatos e situações, de forma amplamente determinada, delimitando negativamente, por meio de redução parcial, a norma de atribuição de poder tributário"41.

Veja-se que a autora fala não apenas em regras expressas, mas também em regras “implicitamente necessárias". Isso porque as imunidades podem estar expressamente previstas no Texto Constitucional ou podem ser implícitas, figurando como decorrência necessária de princípios consagrados pelo ordenamento jurídico. É o caso da imunidade recíproca e da

\footnotetext{
${ }^{38}$ CARVALHO, Paulo de Barros. Direito Tributário: Linguagem e Método, p. 340.

${ }^{39}$ BORGES, José Souto Maior. Teoria Geral da Isenção Tributária, p. 218. No mesmo sentido: BOTTALO, Eduardo Domingos. Fundamentos do IPI. São Paulo: Revista dos Tribunais, 2002, p. 108. Afirma esse autor que: "quando a não-incidência decorre de expressa disposição constitucional, que vede ao legislador ordinário competente instituir determinado tributo, alcançando certa realidade, ou pessoa, estamos diante da figura da imunidade" e que estas seriam então "hipóteses de não-incidência constitucionalmente qualificadas".

${ }^{40}$ BORGES, Souto Maior. Teoria Geral da Isenção Tributária, pp. 218-219.

${ }^{41}$ DERZI, Misabel. Limitações Constitucionais ao Poder de Tributar, nota de atualização, p. 227.
} 
imunidade das instituições de educação e de assistência social sem fins lucrativos, as quais devem ser reconhecidas ainda que inexista qualquer previsão constitucional expressa que as consagre, vez que decorrem do pacto federativo e do princípio da capacidade contributiva ${ }^{42}$.

\subsubsection{A imunidade distingue-se da isenção.}

A imunidade é regra constitucional que delimita a competência tributária. Com isso, já resta claro que ela se distingue da isenção tributária, na medida em que esta última é regra estabelecia pela legislação infraconstitucional, devendo ser instituída por meio de lei ordinária ou complementar, e não delimita a competência tributária, mas antes a pressupõe.

Com efeito, as regras que outorgam poderes para tributar e as regras de imunidade traçam o contorno da competência dos entes federados. Na esfera dessa competência, o ente pode optar por exercê-la integralmente, instituindo todos os tributos previstos pela Constituição, ou pode exercê-la apenas parcialmente, instituindo apenas alguns dos tributos cuja competência lhe foi outorgada. Nessa última hipótese, a esfera de incidência dos tributos não corresponderá exatamente à esfera de competência do ente da Federação.

No entanto, instituídos os tributos por meio de lei, pode a pessoa política optar por afastar a sua incidência no que diz respeito a pessoas, situações ou fatos determinados. Isso se dá através da fixação de regras de isenção tributária, também instituídas através de lei.

Desse modo, como lecionam Misabel Derzi e SACHa CAlmon Navarro COÊLHO, a imunidade e a isenção se diferenciam não apenas sob o aspecto formal, mas também sob o aspecto material, dado que a imunidade é um limite constitucional ao poder de tributar, ao passo que a isenção "é uma auto-limitação, ou seja: quem pode tributar, porque autorizado pela Constituição, auto-limita-se (evidentemente, auto-limitação legislativa, face ao princípio da legalidade da tributação)". Isso porque apenas em casos excepcionais, para os Estados organizados sob a forma federativa, admite-se a interpretação heterônoma, em que um ente federado concede isenção em tributo de competência de outro ente federado ${ }^{43}{ }^{44}$.

Assim, pelas razões expostas, a isenção não se confunde com a imunidade.

\footnotetext{
${ }^{42}$ A favor da existência de imunidades implícitas vide também: SCHOUERI, Luís Eduardo. Direito Tributário, p. 377, e ÁVILA, Humberto. Sistema Constitucional Tributário, p. 274.

43 DERZI, Misabel e COÊLHO, Sacha Calmon Navarro. A Imunidade Intergovernamental Recíproca e sua Extensão às Autarquias Federais. Revista Dialética de Direito Tributário, nº 6, 1996, p. 98.

${ }^{44}$ No caso brasileiro, a isenção heterônoma é admitida em casos especiais, previstos no art. 155, §2, XII, "e”, da Constituição.
} 
Porém, ela também não se confunde com o não exercício da competência tributária. Ao contrário, nos casos de isenção, o ente exercita a sua competência, instituindo o tributo, mas afasta da incidência da exação determinados fatos, pessoas ou situações.

Aqui podemos falar até mesmo em uma aproximação entre as isenções e as imunidades (embora tais fenômenos não se confundam), eis que as isenções também são um non sense quando analisadas de forma isolada, já que só podem ser compreendidas quando analisadas em conjunto com as normas que estabelecem a incidência tributária. 


\subsection{As Imunidades e os Princípios Constitucionais.}

As características expostas acima são relevantes para conceituar as imunidades tributárias, traçando assim os requisitos necessários para a configuração dos seus preceitos.

Contudo, tais características não esgotam o estudo desse tipo de desoneração.

Para AMÍlCAR DE ARAÚJO FALCÃO, a característica formal das imunidades tributárias como regras inseridas na Constituição deve ser vista, antes de tudo, como uma consequência dos fins visados na criação desses preceitos, eis que, através da imunidade, busca-se assegurar princípios fundamentais do regime e valores éticos e culturais que o ordenamento consagra e quer ver protegidos das interferências trazidas pela tributação ${ }^{45}$. É o que também salienta YoNNE DOLÁCIO DE OLIVEIRA, para quem "é o aspecto teleológico da imunidade que informa seu conceito e requer, para sua instituição, o grau mais elevado de normatividade" 46 .

$\mathrm{E}$, de fato, as imunidades são criadas com o fim de proteger valores que o constituinte considerou fundamentais e que, portanto, não poderiam ficar ao sabor das vicissitudes da legislação ordinária, exigindo, ao contrário, consagração constitucional.

Assim é que, para SOUTO MAIOR BorGES, através das imunidades tributárias, são resguardados princípios, ideias-forças ou postulados essenciais ao regime político, de maneira que elas representam muito mais um problema de Direito Constitucional do que um problema de Direito Tributário. Conclui o autor que "analisada sob o prisma do fim, objetivo ou escopo, a imunidade visa assegurar certos princípios fundamentais ao regime, a incolumidade de valores éticos e culturais consagrados pelo ordenamento constitucional positivo e que se pretende manter livres das interferências ou perturbações da tributação"47.

No mesmo sentido o magistério de RoQUe CARRAZZA, para quem as imunidades consagram valores que, em virtude da sua importância, foram postos pelo constituinte já no preâmbulo da Constituição, como a igualdade, a justiça e os direitos individuais e sociais ${ }^{48}{ }^{49}$.

No entanto, a relação entre as imunidades e os princípios constitucionais pode ser mais ou menos intensa a depender do preceito examinado. De fato, analisando-se as

\footnotetext{
${ }^{45}$ FALCÃO, Amílcar de Araújo. Imunidade e Isenção Tributária, pp. 368-369.

${ }^{46}$ OLIVEIRA, Yonne Dolácio de. As Imunidades Genéricas, p. 464.

${ }^{47}$ BORGES, Souto Maior. Teoria da Isenção Tributária, p. 221.

${ }^{48}$ CARRAZA, Roque Antônio. Curso de Direito Constitucional Tributário. 22 $2^{\mathrm{a}}$ ed. São Paulo: Malheiros, 2006, p. 690.

${ }^{49}$ No mesmo sentido ensina YONNE DOLÁCIO DE OLIVEIRA que as imunidades consubstanciam valores inerentes à forma de governo e à base ética da Constituição. Elas são, dessa forma, uma opção normativa e valorativa exercida pelo poder constituinte para a defesa permanente de valores enquanto perdurar a Constituição (in As Imunidades Genéricas, p. 494).
} 
imunidades hoje previstas na Constituição brasileira, é possível verificar que algumas possuem uma relação mais estreita com os valores prestigiados pela Carta, ao passo que outras são específicas para alguns impostos e visam estimular determinados setores econômicos ou mesmo conferir maior coerência ao sistema tributário nacional.

É o que se dá, por exemplo, com a imunidade concedida às exportações, prevista nos arts. $153, \S 3^{\circ}$, III, e 155 , X, "a" da Constituição, que tem pouca relação com os direitos e garantias individuais, mas antes busca prestigiar o princípio do destino na tributação ${ }^{50}$.

O presente trabalho tratará especificamente das imunidades previstas no art. 150, VI, da Constituição de 1988, que incluem: (i) a imunidade recíproca; (ii) a imunidade dos templos de qualquer culto; (ii) a imunidade do partidos políticos e suas fundações, das entidades sindicais dos trabalhadores e das instituições de educação e de assistência social; (iv) a imunidade dos livros, jornais, periódicos e do papel destinado à sua impressão; e (v) a imunidade dos fonogramas e videofonogramas musicais produzidos no Brasil.

Tais desonerações têm sido denominadas pela doutrina de imunidades "genéricas", tendo em vista que abrangem todos os impostos, e são associadas à proteção de diversos princípios consagrados pela Constituição brasileira, tais como a liberdade religiosa, a liberdade de organização partidária e sindical, a livre manifestação do pensamento, a livre expressão da atividade intelectual, artística, científica e de comunicação, dentre outros, como se constata do magistério de AIRES FERNANDINO BARRETO e PAULO AYRES BARRETO ${ }^{51}$ :

\begin{abstract}
As tipificações constitucionais dos fatos, pessoas ou bens sobre os quais não têm as pessoas políticas competência tributária são reveladoras de valores privilegiados pela Constituição, porque decorrentes de princípios nela própria consagrados. $\mathrm{O}$ Constituinte, ao estabelecer, no art. 150, VI, da CF, que é vedado à União, aos Estados, ao Distrito Federal e aos Municípios instituir impostos sobre as situações ali expressamente indicadas, reafirma valores que hão de ser protegidos pela ordem jurídica: expressões de princípios reconhecidamente consagrados pela Constituição.
\end{abstract}

Inclusive por essa razão já decidiu o Supremo Tribunal Federal que tais benefícios não poderiam ser revogados, ou ter a sua esfera reduzida, sequer por emenda constitucional.

Naquela ocasião, a Corte declarou inconstitucional a Emenda Constitucional $\mathrm{n}^{\mathrm{o}}$ 3/1993, na parte em que estabeleceu que o art. 150, VI, da Carta não seria aplicável ao Imposto Provisório sobre a Movimentação ou a Transmissão de Valores e de Créditos e Direitos de Natureza Financeira (IPMF). Argumentou-se que o afastamento das imunidades

\footnotetext{
${ }^{50}$ Nesse sentido: SCHOUERI, Luís Eduardo. Direito Tributário, pp. 376-377.

51 BARRETO, Aires Fernandino e BARRETO, Paulo Ayres. Imunidades Tributárias: Limitações Constitucionais ao Poder de Tributar. $2^{\text {a }}$ ed. São Paulo: Dialética, 2001, p. 59.
} 
do art. 150, VI, não poderia ser admitido em nossa Constituição, visto que exercem uma importante função na proteção dos direitos e garantias individuais e da forma federativa de Estado, que constituem cláusulas pétreas, nos termos do art. $60, \S 4^{\circ}$, I e IV, da Constituição ${ }^{52}$.

E, de fato, a relação entre as imunidades previstas no art. 150, VI, e os princípios constitucionais é tão intensa que algumas delas sequer necessitariam de consagração expressa, já que são uma decorrência necessária desses princípios, os quais, sem as imunidades, não poderiam ser adequadamente protegidos. O exemplo mais claro é o da imunidade recíproca, que decorre naturalmente do pacto federativo, que jamais poderia ser assegurado em sua integralidade caso os entes da Federação pudessem tributar uns aos outros. O mesmo se dá com a imunidade das instituições de educação e de assistência social, as quais, por exercerem atividades de responsabilidade do Estado, já têm todos os seus recursos voltados à realização de fins públicos e, portanto, não poderiam ser obrigadas a arcar também com o pagamento de impostos, tendo em vista os princípios da igualdade e da capacidade contributiva.

As imunidades do art. 150, VI, exercem assim a função de proteger certos princípios constitucionais. Utilizamos o termo "função" na acepção que lhe dá TÉRCIO SAMPAIO FERRAZ JÚNIOR, para quem as normas jurídicas possuem diferentes funções eficaciais.

Segundo o autor, em primeiro lugar, as normas exercem a função de bloqueio, ao impedir ou cercear a ocorrência de comportamentos contrários a seu preceito. Em segundo, exercem a função de programa, eis que se voltam à realização de determinados objetivos, isto é, a um programa que deve ser concretizado. E, por último, as normas jurídicas exercem a função de resguardo, no sentido de que asseguram uma conduta desejada pelo Estado ${ }^{53}$.

Como ressalta FERRAZ JÚNIOR, nem todas as normas exercem a mesma função com o mesmo grau de intensidade. Assim, uma norma de proibição geralmente tem como função primária a função de bloqueio, sendo as funções de programa e resguardo secundárias.

Da mesma forma, as normas de vedação contidas no art. 150, VI, da Constituição Federal brasileira possuem "funções eficaciais". Para FERRAZ JÚNIOR, tratando-se de normas de proibição, elas buscam, em primeiro lugar, impedir ou cercear a ocorrência de determinados comportamentos. Porém, ao proibir, a norma de imunidade também possui uma função programática, na medida em que busca um objetivo a ser concretizado, e uma função

\footnotetext{
${ }^{52}$ ADI n ${ }^{\circ}$ 939/DF, Pleno, Rel. Min. SYDNEY SANCHES, DJ 18.03.1994.

${ }^{53}$ FERRAZ JÚNIOR, Tércio Sampaio. Introdução ao Estudo do Direito: Técnica, Decisão, Dominação. $4^{\mathrm{a}}$ ed. São Paulo: Atlas, 2003, p. 201.
} 
de resguardo, assegurando uma conduta desejada em oposição àquela que se bloqueia, a qual estará em grande parte alinhada aos princípios constitucionais com os quais se relacionam ${ }^{54}$.

Assim, a título de exemplo, é possível sustentar que a imunidade dos livros tem como função primária impedir a tributação desses bens por parte dos entes federados. No entanto, não é essa a sua única função. É possível argumentar que ela também tem como função promover a difusão de ideias e do conhecimento (programa), bem como proteger a livre manifestação do pensamento (resguardo). Da mesma forma, a imunidade das instituições de educação visa evitar a instituição de tributos sobre tais atividades, mas também estimular a criação dessa sorte de entidade, tendo em vista que estas realizam um papel relevante na prestação de serviços educacionais, que são serviços públicos, a toda a população brasileira.

Desse modo, as imunidades tributárias previstas no art. 150, VI, da Carta não devem ser examinadas apenas sob o seu aspecto formal, mas devem ser analisadas também sob o prisma da relação que possuem com os princípios consagrados pela Constituição brasileira. Assim, as funções eficaciais exercidas pelas imunidades, voltadas à proteção e à promoção desses princípios, terão importância fundamental na interpretação desses preceitos.

\footnotetext{
54 FERRAZ JÚNIOR, Tércio Sampaio. Livro Eletrônico e Imunidade Tributária, Revista dos Tribunais Cadernos de Tributário e Finanças Públicas no 22, 1998, pp. 33 e ss.
} 


\subsection{Classificações das Imunidades Tributárias.}

Definido o conceito de imunidade tributária e analisada a sua relação com os princípios constitucionais, cumpre examinar as classificações elaboradas pela doutrina acerca desses preceitos.

A doutrina brasileira já propôs inúmeras classificações das imunidades tributárias, de acordo com a sua abrangência, as pessoas ou coisas alcançadas pelo benefício, a existência ou não de previsão expressa no Texto Constitucional, dentre outras características.

A classificação mais tradicional é aquela que distingue as imunidades entre subjetivas, objetivas ou mistas. As imunidades são subjetivas quando são concedidas em virtude da condição de determinada pessoa. É o caso, por exemplo, da imunidade recíproca e da imunidade das instituições de educação e de assistência social, concedidas em virtude da condição de pessoa política de Direito Público dos entes federados, no primeiro caso, e da condição de entidade sem fins lucrativos prestadora de serviços públicos, no segundo caso.

Por sua vez, as imunidades ditas "objetivas" são aquelas concedidas pela Constituição em virtude da natureza de determinado bem. É a hipótese, por exemplo, da imunidade dos livros, jornais e periódicos e do papel destinado à sua impressão, que tem em vista as obras em si e não as empresas que as produzem ou as comercializam no mercado.

Por fim, a imunidade mista é aquela que se concede em virtude da condição de determinada pessoa e da sua relação com determinada coisa. RUY BARBOSA NOGUEIRA denomina essas imunidades de subjetivas-objetivas, ressaltando assim as suas duas facetas ${ }^{55}$.

Um exemplo de imunidade mista é aquela prevista no art. $153, \S 4^{\circ}$, II, da Constituição brasileira de 1988, que veda a instituição do Imposto sobre a Propriedade Territorial Rural (ITR) sobre as pequenas glebas rurais (critério objetivo), quando exploradas por proprietário que não possua outro imóvel (critério subjetivo).

Frise-se, no entanto, que a classificação em tela não é acolhida por toda doutrina. Para RoQue CARRAZZA, em termos técnicos, a imunidade é sempre subjetiva, já que sempre beneficia a pessoa, quer por sua natureza jurídica (como nas imunidades subjetivas), quer por sua relação com bens, fatos ou situações (como nas imunidades objetivas ou mistas) ${ }^{56}$.

Porém, a distinção é útil na medida em que auxilia na definição da abrangência dos preceitos imunitórios. Com efeito, no caso das imunidades subjetivas, a desoneração

\footnotetext{
${ }^{55}$ NOGUEIRA, Ruy Barbosa. Curso de Direito Tributário. 14ª ed. São Paulo: Saraiva, 1995, pp. 169-170.

${ }^{56}$ CARRAZA, Roque Antônio. Curso de Direito Constitucional Tributário, p. 683.
} 
alcança também os tributos incidentes sobre a renda e o patrimônio da pessoa indicada, ao passo que, na imunidade objetiva, tais tributos não são afastados. Assim, a título de exemplo, as empresas jornalísticas não estão obrigadas ao recolhimento do Imposto sobre Operações relativas à Circulação de Mercadorias e sobre Prestações de Serviços de Transporte Interestadual e Intermunicipal e de Comunicação (ICMS) incidente sobre a venda das suas obras, mas estão obrigadas a recolher o Imposto de Renda sobre os seus rendimentos.

As imunidades tributárias também podem ser classificadas em condicionadas e incondicionadas. As primeiras são aquelas cuja fruição está sujeita ao cumprimento de determinados requisitos. Exemplo clássico de imunidade condicionada pode ser encontrado no art. 150, VI, “c", da Constituição brasileira, eis que as entidades indicadas nesse dispositivo devem cumprir os requisitos fixados em lei para que possam fazer jus à desoneração. Em contraposição, as imunidades incondicionadas são aquelas cuja fruição não está sujeita ao atendimento de qualquer requisito, sendo exemplo disso a imunidade do art. 150, VI, “d”, que alcança os livros, jornais e periódicos e o papel destinado à sua impressão

GERALDO ATALIBA também classificava as imunidades tributárias em genéricas e específicas, de acordo com os tributos abrangidos pelo preceito. Ensinava o autor que as imunidades gerais são aquelas previstas no art. 150, VI, da Constituição e que alcançam genericamente todo e qualquer imposto e que têm como objetivo prestigiar valores básicos consagrados pelo Texto Constitucional. Por sua vez, as imunidades tópicas ou especiais são aquelas desonerações limitadas a casos, situações ou fatos determinados e que estão restritas a um determinado tipo de tributo e voltam-se à consecução de um objetivo específico ${ }^{57}$.

ATALIBA também classificava as imunidades em excludentes ou incisivas. As imunidades excludentes são aquelas que afastam a instituição de certos impostos sobre pessoas ou coisas. Por sua vez, as imunidades incisivas correspondem àquelas que reservam certas situações à tributação por um só imposto ou diversos impostos do mesmo tipo ${ }^{58}$.

Nessa classificação, seriam exemplos de imunidades excludentes aquelas previstas no art. 150, VI, da Constituição e exemplo de imunidade incisiva aquela prevista no art. $155, \S 3^{\circ}$, segundo o qual, à exceção dos impostos previstos no art. 155, II, e no art. 153, I e II, nenhum outro imposto poderá incidir sobre operações relativas a energia elétrica, serviços de telecomunicações e derivados de petróleo, combustíveis e minerais do país.

\footnotetext{
57 ATALIBA, Geraldo. Venda de Minérios - Faturamento - PIS. Revista de Direito Administrativo, $\mathrm{n}^{\circ}$ 196, 1994, pp. 306-307.

${ }^{58}$ Ibidem, p. 308.
} 
Por fim, outra classificação tradicional na doutrina brasileira é aquela que diferencia as imunidades entre expressas e implícitas. Como visto acima, certas imunidades podem ser reconhecidas ainda que não haja consagração expressa no Texto Constitucional, já que decorrem de princípios como a capacidade contributiva e do pacto federativo. Assim, haverá imunidade implícita nas hipóteses em que a desoneração, embora não tenha sido expressamente instituída, possa ser construída através da interpretação como uma decorrência necessária de outras normas inseridas na Constituição. Por sua vez, as imunidades expressas, como a denominação já diz, são aquelas expressamente previstas pelo Texto Constitucional. 


\title{
2.5. Tributos Abrangidos pelas Imunidades Tributárias.
}

No capítulo anterior foi observado que o termo "imunidade" (ou "immunitas") correspondia à noção de negação do munus público. Por essa razão, as imunidades são tradicionalmente associadas a uma vedação à instituição de impostos sobre determinadas pessoas, bens ou situações, tendo em vista que estes são os tributos voltados ao custeamento dos gastos coletivos, exigidos em conformidade com o princípio da capacidade contributiva.

As imunidades serviriam assim para desonerar certas pessoas do recolhimento dessa espécie de tributo, em virtude de razões como a ausência de capacidade contributiva ou a necessidade de se prestigiarem certos valores vistos como caros pelo Texto Constitucional ${ }^{59}$.

Diante disso, alguns autores passaram a sustentar que as imunidades tributárias poderiam abarcar apenas impostos, não sendo aplicáveis a outras espécies de tributos, como, por exemplo, as taxas, eis que, nesses casos, a exigência possui uma natureza contraprestacional, visando remunerar o Estado pelos serviços prestados a determinado contribuinte. Exemplo desse entendimento pode ser encontrado na obra de IVES GANDRA DA SILVA MARTINS intitulada “Comentários à Constituição do Brasil”, na qual afirma o autor ${ }^{60}$ :

\begin{abstract}
A imunidade diz respeito aos impostos. Não se aplica às outras espécies tributárias. Há uma razão para que assim seja, posto que as demais espécies são vinculadas a determinadas atividades. As taxas têm ou uma faceta contraprestacional de serviços públicos e divisíveis ou outra de exercício de poder de polícia.

A contribuição de melhoria é apenas cabível em havendo melhoria de imóvel para seu pagador.

As demais contribuições especiais vinculam-se à sua finalidade. As sociais destinadas à seguridade social, as de intervenção no domínio econômico para regulála e as de interesse das categorias sociais para mantê-las. Por outro lado, o empréstimo compulsório apenas se justifica nos casos de calamidade pública, guerra externa ou investimento público relevante.

Em outras palavras, as demais espécies tributárias não podem ser objeto de imunidade constitucional porque estão vinculadas a suas finalidades específicas.

Desta forma, apenas em havendo desoneração infraconstitucional admite-se a extrafiscalidade, como instrumento de política tributária, para tais espécies.

Nos impostos, não há vinculação e seu espectro abrangente justifica o tratamento desonerativo em nível constitucional, vedando, por inteiro, a ação impositiva do poder tributante.
\end{abstract}

Ocorre que a Constituição brasileira consagrou expressamente em seu texto diversas desonerações relativas às taxas, tais como as previsões do art. 5", XXXIV, "a" e "b",

\footnotetext{
${ }^{59}$ Veja nesse sentido SCHOUERI, Luis Eduardo. Direito Tributário, pp. 375-376.

${ }^{60}$ MARTINS, Ives Gandra da Silva. Comentários à Constituição do Brasil. Vol. 6. Tomo I. São Paulo: Saraiva, 1990, pp. 172-173.
} 
segundo o qual deve ser assegurado a todos, independentemente do pagamento de taxas, o direito de petição aos Poderes Públicos em defesa de direitos ou contra ilegalidade ou abuso de poder e a obtenção de certidões em repartições públicas, para defesa de direitos e esclarecimento de situações de interesse pessoal; do art. $5^{\circ}$, LXXIII, o qual prevê que os cidadãos poderão propor ação popular sem o pagamento das custas iniciais e do ônus da sucumbência; do art. 5\%, LXXIV, segundo o qual o Estado prestará assistência jurídica integral e gratuita aos que comprovarem insuficiência de recursos; do art. 5, LXXVI, que estabelece a gratuidade do registro civil de nascimento e da certidão de óbito para todos aqueles que forem reconhecidamente pobres; do art. $5^{\circ}$, LXXVII, segundo o qual são gratuitas as ações de habeas corpus e habeas data, bem como os atos necessários ao exercício da cidadania, os quais foram definidos pela Lei $\mathrm{n}^{\circ}$ 9.265/1996 e incluem, dentre outros, os atos referentes ao alistamento militar, pedidos de informações ao poder público objetivando a instrução de defesa ou denúncia de irregularidades administrativas, ações de impugnação de mandato eletivo por abuso do poder econômico, corrupção ou fraude; dentre outras previsões.

Em todos os casos acima citados, há um serviço público e específico prestado a um contribuinte em particular, o que poderia ensejar a cobrança de taxas por parte do Estado. No entanto, em todos os casos, foi estabelecida constitucionalmente a desoneração tributária, em virtude de fatores como a ausência de capacidade econômica e a necessidade de se assegurar direitos essenciais ao exercício da cidadania, como o direito de petição. Não há dúvidas assim que, em todas as hipóteses elencadas, estabeleceu-se verdadeira imunidade.

Diante disso, tendo em vista a ordem jurídica brasileira, não se pode afirmar que as imunidades tributárias alcançariam apenas os impostos, eis que nosso Texto Constitucional consagrou expressamente hipóteses de imunidades referentes a outras espécies tributárias.

É o que também concluem Roque CarrazZA ${ }^{61}$ E Regina Helena Costa ${ }^{62}$, para quem as imunidades podem versar sobre outras espécies de tributos além dos impostos.

No mesmo sentido o magistério de PAulo de Barros Carvalho. Segundo o autor, a afirmação de que a imunidade é instituto que só se refere aos impostos não pode ser acolhida, uma vez que traduz uma exacerbada extensão de uma particularidade constitucional e que não se confirma no atual texto da Constituição Federal brasileira, já que este abriga regras de imunidades que fazem alusão explícita a outras espécies tributárias, como as taxas ${ }^{63}$.

\footnotetext{
${ }^{61}$ CARRAZZA, Roque Antônio. Curso de Direito Constitucional Tributário, pp. 692 e ss.

${ }^{62}$ COSTA, Regina Helena. Imunidades Tributárias, pp. 44-46

${ }^{63}$ CARVAlHO, Paulo de Barros. Curso de Direito Tributário, pp. 197-199.
} 
Entretanto, fato é que as situações mais relevantes de imunidades tributárias hoje previstas na Constituição brasileira ainda estão, na sua maioria, voltadas aos impostos.

É o caso das imunidades do art. 150, VI, da Constituição. Tais desonerações alcançam apenas essa espécie de tributo, eis que a Carta estabelece expressamente que é vedada a instituição de impostos sobre as pessoas, as situações e os bens nela indicados.

Nesse ponto, não concordamos com aqueles que afirmam que a Constituição foi atécnica ao se referir a impostos, quando, na realidade, queria abranger todos os tributos.

Fosse assim e não haveria razão para a previsão do art. $195, \S 7^{\circ}$, da Carta, que estabelece a imunidade às contribuições para a Seguridade Social das entidades beneficentes de assistência social, vez que tal benefício já estaria contido no art. 150, VI, “c”, que imuniza todas as instituições de educação e de assistência social que não possuam fins lucrativos.

Esse também tem sido o entendimento adotado pela jurisprudência.

Com efeito, ainda na vigência da Constituição Federal de 1946, que, em seu art. 31 , V, vedava a instituição de impostos sobre bens, rendas e serviços dos entes federados, o Supremo Tribunal Federal editou a Súmula no 324, de 13.12.1963, a qual estabelecia que a imunidade tributária em questão não compreendia as taxas.

Esse entendimento foi mantido para as Constituições posteriores e permanece até os dias atuais, havendo inúmeros julgados daquele Tribunal que afirmam que as imunidades hoje previstas no art. 150, VI, da Constituição abrangem apenas os impostos, não tendo o condão de alcançar outras espécies tributárias, tais como taxas e contribuições de melhoria ${ }^{64}$.

\footnotetext{
${ }^{64}$ Vide nesse sentido os seguintes julgados: RE ${ }^{\circ}$ 68.873/GB, $1^{\text {a }}$ Turma, Rel. Min. ALIOMAR BALEEIRO, DJ 24.04.1970; RE $n^{\circ}$ 68.788/GB, $2^{\mathrm{a}}$ Turma, Rel. Min. XAVIER DE ALBUQUERQUE, DJ 18.05.1973; RE $\mathrm{n}^{\circ}$ 211.782/PR, $2^{\mathrm{a}}$ Turma, Rel. Min. NÉRI DA SILVEIRA, DJ 24.03.2000; RE n ${ }^{\circ}$ 253.394/SP, $1^{\mathrm{a}}$ Turma, Rel. Min. ILMAR GALVÃO, DJ 11.04.2003; RE $\mathrm{n}^{\mathrm{o}}$ 424.227/SC, $2^{\mathrm{a}}$ Turma, Rel. Min. CARLOS VELLOSO, DJ

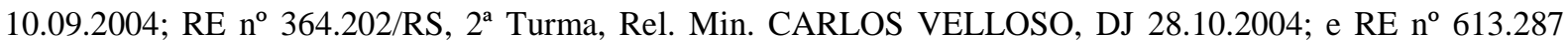
AgR/RS, $1^{\text {a }}$ Turma, Rel. Min. LUIZ FUX, DJe 18.08.2011.
} 
3. Interpretação das Imunidades Tributárias. 


\subsection{Interpretação e o Direito.}

Nos últimos séculos, foram desenvolvidas pela doutrina inúmeras teorias sobre a interpretação jurídica. Não obstante as diferenças existentes entre elas, é possível encontrar algumas semelhanças no que diz respeito à concepção de linguagem adotada e no que tange ao papel exercido pela interpretação, que permitem o seu agrupamento em correntes teóricas.

Nesse ensejo, GUASTINI propõe uma classificação das teorias sobre a interpretação jurídica em três correntes, vale dizer: (i) a cognitivista, (ii) a cética e (iii) a eclética ${ }^{65}$.

A teoria cognitivista é a teoria tradicional de interpretação e foi em grande parte influenciada por uma concepção particular da linguagem, segundo a qual as palavras poderiam "apontar" para as coisas, possuindo um conteúdo preexistente. De acordo com essa teoria, caberia ao hermeneuta apenas extrair o sentido já imanente aos termos da linguagem.

Para LARENZ, essa concepção explica a expressão utilizada na língua alemã para tratar da interpretação (Auslegung), que corresponde a um desentranhamento (Auseinanderlegung), isto é, à difusão e exposição do sentido já contido no texto, porém oculto. A interpretação seria assim uma forma de "fazer falar o texto", sem que o intérprete pudesse acrescentar nada ${ }^{66}$.

$\mathrm{Na}$ teoria cognitivista, o ato de interpretação é apenas um ato de conhecimento, de descoberta ou desvelamento do sentido da lei. Essa teoria, evidentemente, pressupõe que o texto possui um sentido que está incorporado a ele e que preexiste ao ato de interpretação. $\mathrm{O}$ intérprete, nesse cenário, não exerceria qualquer atividade criativa, mas apenas traria à luz o sentido que já está contido no preceito normativo. De acordo com a teoria cognitivista, o texto seria suscetível de apenas uma interpretação e o Direito admitiria apenas uma solução correta.

Essa concepção prevaleceu na Idade Média. Entendia-se que a interpretação correspondia à extração do sentido já imanente ao texto. Inclusive, nos casos em que o texto se fizesse claro e inequívoco, não caberia sequer interpretação, entendimento que deu origem ao brocardo "in claris non fit interpretatio", adotado pelos juristas medievais ${ }^{67}$.

\footnotetext{
${ }^{65}$ GUASTINI, Riccardo. Interpretare e Argomentare. Milão: Giuffre, 2011, pp. 408 e ss. Como salientado, a classificação em tela é uma simplificação, visto que ignora certas particularidades das teorias encampadas por cada autor. No entanto, é valiosa na medida em que ressalta as principais premissas teóricas adotadas por cada corrente acerca do papel da linguagem e da interpretação jurídica.

${ }^{66}$ LARENZ, Karl. Metodologia da Ciência do Direito. $6^{\mathrm{a}}$ ed. Lisboa: Calouste Gulbenkian, 2012, p. 441.

${ }^{67}$ NEVES, A. Castanheira. Interpretação Jurídica, in Digesta, Escritos acerca do Direito, do Pensamento Jurídico, da sua Metodologia e Outros. Vol. 2. Coimbra: Coimbra Editora, 1995, p. 338.
} 
Não se pode ignorar que essa concepção traduzia uma desconfiança nos aplicadores do Direito, negando-os qualquer atividade criadora e buscando-se assim conter o arbítrio judicial e garantir a certeza jurídica ${ }^{68}$. De fato, como iremos perceber no decorrer desse capítulo, a definição do papel exercido pela interpretação jurídica reflete em grande medida um embate entre o legislador e o juiz pelo controle sobre a criação do Direito.

Como aponta A. CAStanheira Neves, nas épocas de forte apelo legislativo, como na Idade Média, o legislador tomou a si o poder sobre a criação do Direito, reduzindo o papel do juiz a quase nada, o que se verifica desde Justiniano até a Revolução Francesa, pela instituição do référé législatif ${ }^{69}$. Também se constata a predominância do legislador na criação de instituições voltadas ao controle da interpretação judicial, como se deu na criação do tribunal de cassação francês, que tinha como escopo garantir a estrita obediência às leis mediante a censura da contravenção ao texto expresso da lei. Desse modo buscava-se reafirmar a legalidade contra o poder criador dos juízes manifestado na interpretação ${ }^{70}$.

No contexto da teoria cognitivista da interpretação, o debate da hermenêutica jurídica centrava-se em três temas principais: (i) o objetivo ou fim da interpretação, (i) os elementos, fatores ou critérios da interpretação, e (iii) os resultados da interpretação ${ }^{71}$.

Entendia-se que a lei possuía uma letra e também um espírito, cabendo ao intérprete perquirir qual era o espírito da lei e em que medida este coincidia com a sua letra.

Especificamente quanto ao objetivo da interpretação, a polêmica residia no debate entre o subjetivismo e o objetivismo interpretativos e entre a interpretação dogmática e a interpretação teleológica. Quanto aos primeiros, tratava-se de definir se a interpretação deveria buscar o espírito da lei na vontade do legislador, entendida como vontade real, histórica ou psicológica, ou se deveria buscá-lo no sentido objetivo da lei, considerando-se assim que o texto legal exprimiria um sentido autônomo (a chamada "mens legis") ${ }^{72}$.

Quanto à interpretação dogmática e à interpretação teleológica, tratava-se de definir se a interpretação deveria buscar o sentido da norma no sistema jurídico dogmático, sendo a interpretação uma espécie de explicitação da ordem que é o Direito, ou, por outro lado, se a interpretação deveria ter em vista fins práticos, tendo como objetivo a realização dos fins e dos valores que o ordenamento jurídico buscou atingir, isto é, sua teleologia.

\footnotetext{
${ }^{68}$ NEVES, A. Castanheira. Interpretação Jurídica, in Digesta, pp. 338 e ss.

${ }^{69}$ O chamado référé législatif foi instituído pela Revolução Francesa através do Decreto de 24/8/1790 e estabelecia que os tribunais deveriam ouvir o Poder Legislativo sempre que fosse necessário interpretar a lei.

${ }^{70}$ NEVES, A. Castanheira. Interpretação Jurídica, in Digesta, pp. 338 e 339.

${ }^{71}$ Ibidem, pp. 353 e ss.

${ }^{72}$ Ibidem, pp. 355-357.
} 
Por sua vez, quanto aos elementos (fatores ou critérios) da interpretação jurídica, consagrou-se a tese de FRIEDRICH VON SAVIGNY, que, em sua primeira fase, desenvolveu quatro elementos da interpretação: o elemento lógico, o elemento sistemático, o elemento gramatical e o elemento histórico, tendo o elemento lógico sido reduzido posteriormente ao sistemático ${ }^{73}$.

O elemento gramatical é aquele que faz referência ao texto da lei e ao uso de regras gramaticais, analisando o sentido ordinário e o sentido técnico das expressões. $\mathrm{O}$ elemento histórico visa à investigação das circunstâncias históricas que deram origem ao preceito normativo, examinando os trabalhos preparatórios que levaram à edição da lei e as circunstâncias sociais que a antecederam. Por último, o elemento sistemático equivale a analisar o dispositivo em cotejo com todo o ordenamento jurídico em que ele se insere.

Frise-se que, inicialmente, SAVIGNY negava a possibilidade de uma interpretação "teleológica", vez que o juiz não deveria atender ao que o legislador buscou atingir, mas ao que ele efetivamente exprimiu no texto da le $^{74}$. No entanto, tal concepção foi alterada a partir do momento em que SAVIGNY passa a considerar como fonte originária do Direito não a lei, mas a convicção jurídica comum do povo, o "espírito do povo". O autor afirma então que, embora a razão de ser da lei não se confunda com o seu conteúdo, ela pode ser utilizada no trabalho interpretativo, de modo que, sendo indeterminada a expressão da lei, o intérprete poderia recorrer ao seu fim especial, quando fosse comprovável, ou mesmo a uma razão geral.

Assim, a interpretação jurídica faria uso dos elementos gramatical, histórico, sistemático e teleológico. Frise-se que, mesmo para SAVIGNY, tais elementos não corresponderiam a quatro espécies distintas de interpretação, mas sim a diferentes atividades que deveriam ser realizadas conjuntamente no decorrer do trabalho interpretativo ${ }^{75}$.

Por fim, o debate da hermenêutica tradicional voltava-se também aos resultados da interpretação jurídica. A análise era realizada de acordo com a distinção entre a letra da lei (o seu texto) e o espírito da lei (que, como visto, para os subjetivistas correspondia à vontade do legislador e para os objetivistas, a um sentido imanente à própria norma).

Tal análise poderia dar origem a três diferentes resultados ${ }^{76}$.

No primeiro caso, a letra e o espírito coincidiriam, ou seja, o significado gramatical do texto da lei exprimiria adequadamente o seu espírito, sendo a interpretação

\footnotetext{
73 A metodologia desenvolvida por SAVIGNY é exposta em detalhes por LARENZ, Karl. Metodologia da Ciência do Direito, pp. 10 e 11.

${ }^{74}$ Ibidem, pp. 11 e 12.

${ }^{75}$ Ibidem, pp. 13 e ss.

${ }^{76}$ NEVES, A. Castanheira. Interpretação Jurídica, in Digesta, pp. 366-367.
} 
meramente declarativa. No segundo caso, a letra seria mais ampla do que o espírito da lei, cabendo à interpretação restringir o sentido textual da lei (o que foi denominado então de “interpretação restritiva”). E no último caso, a letra seria menos ampla do que seu espírito, cabendo à interpretação alargar o sentido textual da lei (a dita "interpretação extensiva").

Pois bem. Com o desenvolvimento dos estudos sobre a linguagem, perdeu força a noção de que as palavras pudessem ter um conteúdo imanente, preexistente à interpretação. Consequentemente, também passou a ser questionada a ideia de que a interpretação jurídica pudesse ser um mero ato de conhecimento e de subsunção mecânica dos fatos à norma.

$\mathrm{E}$, de fato, os termos da linguagem não possuem um sentido imanente, que esteja incorporado ao texto e que possa ser apenas revelado através do trabalho interpretativo.

A linguagem só pode ser bem entendida quando analisada sob uma perspectiva pragmática, eis que o sentido não está incorporado às palavras, mas é atribuído pelos utentes da linguagem situados em uma comunidade. Como leciona WiTTGENSTEIN, o significado das palavras não é uma propriedade destas, mas deve ser compreendido a partir do modo como são utilizadas em determinado setor social, através dos chamados "jogos de linguagem"77.

Diante disso, a interpretação não pode ser um ato de extração do sentido já contido no texto, mas deve ser um ato de construção do sentido a ser realizado pelo intérprete.

Ademais, o Direito é indeterminado, tendo em vista que os textos normativos são equívocos, de modo que não se sabe exatamente quais normas estão em vigor, muitos dos seus enunciados são ambíguos, eis que podem expressar duas normas distintas (é dizer, o mesmo texto normativo pode expressar a norma N1 ou pode expressar a norma N2), os enunciados podem também ter um conteúdo de sentido complexo, no sentido de que expressam ou implicam uma pluralidade de normas conjuntamente (a título de exemplo, entende-se que um texto normativo expressa a norma N1, mas também pode implicar a norma $\mathrm{N} 2$ ), por vezes também se entende que um texto normativo expressa uma norma, mas questiona-se se tal norma não é defectível (defeasible), isto é, está sujeita a exceções implícitas, que não podem ser identificadas a priori e, por fim, há também normas não expressas, no sentido de que não correspondem a um enunciado normativo específico ${ }^{78}$.

Frise-se que a equivocidade dos textos normativos não depende apenas de certos defeitos da sua formulação, mas também - e principalmente - de outros fatores, incluindo a

\footnotetext{
77 WITTGENSTEIN, Ludwig. Philosophical Investigations. $4^{\mathrm{a}}$ ed. Tradução de G.E.M. Anscombe, P.M.S. Hacker e Joachim Schulte. Singapura: Blackwell Publishing, 2009. Uma análise detalhada sobre a obra de WITTGENSTEIN e sua relação com o Direito Tributário é feita por ANDRADE, José Maria Arruda de. Interpretação da Norma Tributária. São Paulo: MP Editora, 2006.

${ }^{78}$ GUASTINI, Riccardo. Interpretare e Argomentare, pp. 39 e ss.
} 
multiplicidade de métodos interpretativos que podem ser adotados, a dogmática jurídica e os juízos de valor dos intérpretes. Com efeito, o mesmo enunciado pode adquirir diferentes sentidos a depender do método de interpretação utilizado pelo aplicador do Direito. A título de exemplo, a utilização do argumento a contrario pode ensejar resultados radicalmente distintos da aplicação do argumento analógico, e isso em face de idêntico texto normativo ${ }^{79}$.

Ademais, como leciona GUASTINI, todo intérprete se aproxima do texto normativo provido de algumas pressuposições teóricas, que influenciam a sua interpretação.

GADAMER, ao tratar da interpretação, já trazia a ideia da pré-compreensão. Para o autor, toda interpretação teria início com conceitos prévios, que vão sendo progressivamente substituídos por outros mais adequados. Ensinava GADAMER que esse constante reprojetar é o movimento de compreender e interpretar de que fala HEIDEGGER e "quem busca compreender está exposto a erros de opiniões prévias que não se confirmam nas próprias coisas"80.

Ressaltava o autor que tais opiniões prévias, pré-conceitos ou pré-juízos não são um mal em si, mas, ao contrário, são um pressuposto para a compreensão, já que para compreender é necessário, em primeiro lugar, ser versado na coisa em questão ${ }^{81}$. Préconceitos são entendidos como juízos que se formam antes de um exame definitivo de todos os elementos do objeto a ser interpretado e que podem ser substituídos no decorrer da interpretação. Frise-se que os pré-conceitos de que fala para GADAMER não são uma construção individual de cada intérprete, já que todo indivíduo está inserido na tradição ${ }^{82}$.

Da mesma forma, o aplicador do Direito, quando se depara com um texto normativo a ser interpretado, já possui algumas noções prévias sobre ele. O aplicador também já traz consigo diversas construções dogmáticas antes mesmo de iniciar o trabalho interpretativo. Como aponta GUASTINI, tais construções irão condicionar a sua interpretação, fazendo com que o aplicador dê preferência a determinadas decisões interpretativas em detrimento de outras ou que exclua certas decisões que a princípio seriam possíveis.

Inclusive por essa razão, muitos preferem definir o trabalho interpretativo não como construção, mas como reconstrução do sentido, eis que essa atividade sempre irá partir de conceitos prévios e usos linguísticos já consolidados acerca do texto a ser interpretado.

\footnotetext{
${ }^{79}$ GUASTINI, Riccardo. Interpretare e Argomentare, pp. 48-49.

${ }^{80}$ GADAMER, Hans-Georg. Verdade e Método: Traços Fundamentais de uma Hermenêutica Filosófica. Vol. I. $12^{\mathrm{a}}$ ed. Petrópolis: Vozes, 2012, p. 356.

${ }^{81}$ Ibidem, p. 390.

${ }^{82}$ Ibidem, pp. 367-368.
} 
A indeterminação do Direito também decorre da vagueza das normas, dado que os enunciados normativos estão vertidos em linguagem e a linguagem é, por sua natureza, vaga. Com efeito, muitas vezes o legislador faz uso de palavras que não denotam uma entidade individual, mas sim uma classe (como os termos "contrato", "associação", "pessoa jurídica" etc.), não sendo possível afirmar quais hipóteses estão abrangidas pela norma analisada ${ }^{83}$.

Diante dessas constatações, passaram a surgiu na doutrina outras teorias sobre a interpretação jurídica, que GUASTINI classifica em teorias céticas e teorias ecléticas.

A teoria cética predica que a interpretação não é apenas um ato de conhecimento, mas também um ato de vontade. De acordo com essa corrente, o texto não possuiria um sentido pré-constituído, mas a atribuição do sentido seria fruto de uma decisão do intérprete.

GUASTINI aponta duas variantes da teoria cética: a moderada e a radical ${ }^{84}$.

Para a teoria moderada, o mesmo texto normativo poderia receber algumas interpretações distintas e igualmente plausíveis, cabendo ao intérprete escolher o sentido a ser adotado. Já para a teoria radical, o texto normativo não possuiria qualquer significado préconstituído, sendo o intérprete totalmente livre para atribuir qualquer sentido à lei.

Por fim, de acordo com a teoria eclética, a interpretação poderia corresponder a um ato de conhecimento ou a um ato de vontade, a depender das circunstâncias do caso ou do texto normativo em questão. Assim, em sua primeira variante, afirma-se que as leis possuem uma "textura aberta" e são caracterizadas pela imprecisão e pela indeterminação, de modo que haveria um núcleo de significado de um lado e uma "zona de penumbra" ou de incerteza de outro. Assim, para os casos que estivessem abrangidos pelo núcleo de significado (casos fáceis), a interpretação seria um mero ato de conhecimento, de descrição do sentido, e para os casos que estivessem na zona de penumbra (casos difíceis), a interpretação seria um ato de decisão, dado que a aplicação da norma seria dúbia. Em sua segunda variante, a interpretação dependeria do tipo de formulação linguística adotado no texto da lei, isto é, se a linguagem é inequívoca ou obscura: no primeiro caso, sendo o texto claro, a interpretação seria apenas um ato de conhecimento e não de decisão, ao passo que, para textos obscuros ou ambíguos, a interpretação seria um ato de vontade, traduzido na escolha entre os sentidos possíveis.

Como se pode ver, as teorias ecléticas ainda sofrem o influxo da noção tradicional da linguagem, tendo em vista que admitem que, em determinados casos, o texto possa ser totalmente inequívoco ou claro e a interpretação possa ser apenas um ato de conhecimento.

\footnotetext{
${ }^{83}$ GUASTINI, Riccardo. Interpretare e Argomentare, pp. 52 e ss.

${ }^{84}$ Ibidem, pp. 413 e ss.
} 
Com efeito, como aponta José MARIA ARRUda DE ANDRADE, tais teorias são, muitas vezes, meras flexibilizações das teorias tradicionais, ora referindo à "carga subjetiva" da interpretação jurídica, que sofreria o influxo das opiniões pessoais dos aplicadores, ora à "textura aberta" das palavras, que possibilitariam, em certos casos, a obtenção de múltiplas significações para o mesmo preceito. No entanto, por serem meras "flexibilizações", essas teorias não abandonam de fato a antiga noção de que as palavras possuiriam um sentido imanente, admitindo a atividade criadora do intérprete apenas em caráter excepcional ${ }^{85}$.

Ocorre que a natureza criadora do trabalho interpretativo não tem caráter excepcional, mas, antes, é elemento essencial e necessário para sua adequada compreensão ${ }^{86}$.

Frise-se que não se está aqui a afirmar que o intérprete possa atribuir qualquer sentido às expressões da lei, como faz a teoria cética radical acima exposta.

Como bem leciona GADAMER, a linguagem não é uma posse à disposição do interlocutor, mas está inserida em um momento histórico e em uma sociedade ${ }^{87}$. Assim, nenhum indivíduo pode construir, a partir do texto normativo, uma interpretação totalmente nova e absolutamente dissociada da sociedade e do momento histórico em que está inserido.

Assim, embora o texto não possua um sentido único ou pré-constituído, é possível falar em um sentido literal possível do texto, tendo em vista o uso linguístico geral ou, caso seja possível constatar um tal uso, o uso linguístico especial do falante concreto.

Utilizamos a expressão "sentido literal possível” na acepção trazida por KARL LARENZ. Para esse autor, dentro do sentido possível, é possível distinguir o "âmbito nuclear" do termo e os fenômenos situados na sua "franja marginal", os quais no uso linguístico geral são só algumas vezes considerados. Para LARENZ, a interpretação denominada "restritiva" ou "estrita" é aquela em que o significado do termo é identificado com o seu âmbito nuclear, ao passo que a interpretação "extensiva" é aquela em que o significado compreende não só o núcleo do termo, mas também certos fenômenos situados na sua franja marginal.

De acordo com essa concepção, o que está para além do sentido literal possível e é claramente excluído por ele não pode ser entendido, por meio da interpretação, como o significado do termo em questão. Assim, o teor literal possui uma dupla função: é o ponto de partida para a indagação do sentido do texto e traça os limites da interpretação. Caso a

\footnotetext{
${ }^{85}$ ANDRADE, José Maria Arruda de. Interpretação da Norma Tributária, pp. 77 e ss.

${ }^{86}$ Neste trabalho, utilizamos a palavra "criação" na acepção de construção do sentido, em oposição à ideia de interpretação como desentranhamento ou desvelamento do sentido, presente nas teorias cognitivistas tradicionais. Assim, para os propósitos deste trabalho, "criação" não se confunde com o desenvolvimento do Direito, isto é, com as hipóteses em que o intérprete constrói o sentido além do sentido literal possível do texto.

${ }^{87}$ GADAMER, Hans-Georg. Verdade e Método, p. 493.
} 
interpretação vá além do sentido literal, a hipótese não será propriamente de interpretação jurídica, mas de desenvolvimento do Direito, que deve seguir certos pressupostos especiais ${ }^{88}$.

Logo, quando o intérprete, tendo em vista a finalidade da norma, atribui um sentido que transcende a franja marginal do texto ou exclui fenômenos que se situam claramente no âmbito nuclear não estamos mais falando de interpretação. No primeiro caso, tratar-se-á de uma analogia e, no segundo caso, de uma redução teleológica da lei ${ }^{89}$. Logo, tanto a analogia quanto a redução teleológica são hipóteses de desenvolvimento do Direito.

No entanto, no âmbito do sentido literal possível, o intérprete pode atribuir diferentes sentidos a um determinado texto. Nesse trabalho, estaria o aplicador do Direito livre para escolher arbitrariamente qualquer um dos sentidos, de acordo com a sua vontade?

KELSEN afirmava que o Direito era uma estrutura escalonada de normas jurídicas e que as normas superiores poderiam determinar não só o órgão competente e o procedimento adequado para a criação das normas inferiores, como também o seu conteúdo. No entanto, afirmava o autor que tal determinação de conteúdo nunca era completa, restando sempre uma margem de discricionariedade ao aplicador. Assim, para KELSEN, a norma superior poderia fornecer, por meio de um ato de conhecimento, apenas uma "moldura" para a decisão judicial, dentro da qual o juiz poderia escolher livremente diferentes significações possíveis. Nesse contexto, a escolha de uma das significações consistiria em um mero ato de vontade, não sendo possível definir qual seria a interpretação correta de determinada norma jurídica ${ }^{90}$.

Tal entendimento não pode ser sustentado.

Com efeito, a Ciência do Direito deve fornecer critérios para o controle das decisões judiciais, que não podem ser consideradas mero ato de vontade, sujeito ao arbítrio do julgador. Tendo em vista que tais critérios não podem ser fornecidos integralmente pelo texto, que, como visto, não possui um conteúdo imanente, é necessário controlar a interpretação jurídica por meio da análise do discurso argumentativo adotado pelos aplicadores do Direito.

Um argumento interpretativo corresponde a uma razão, a uma premissa de um raciocínio, que um intérprete apresenta para sustentar uma determinada tese interpretativa ${ }^{91}$.

Tais argumentos podem levar em conta diferentes fatores, tais como as circunstâncias históricas que deram origem à edição da lei a ser interpretada, a relação de uma regra jurídica com outras normas inseridas no ordenamento, os fins visados pela norma, as consequências políticas ou econômicas de determinada linha interpretativa, dentre outros.

\footnotetext{
${ }^{88}$ LARENZ, Karl. Metodologia da Ciência do Direito, pp. 450 e ss.

${ }^{89}$ LARENZ, Karl. Metodologia da Ciência do Direito, pp. 500 e 501.

${ }^{90}$ KELSEN, Hans. Teoria Pura do Direito. São Paulo: Martins Fontes, 2000, pp. 387 e ss.

${ }^{91}$ GUASTINI, Riccardo. Interpretare e Argomentare, p. 267.
} 
Tendo em vista a multiplicidade dos argumentos passíveis de utilização na interpretação jurídica, ÁvILA propõe uma classificação desses argumentos de acordo com a relação que estes possuem com o ordenamento jurídico em que se insere o preceito a ser interpretado. Tal classificação é exposta pelo autor através do quadro reproduzido abaixo ${ }^{92}$ :

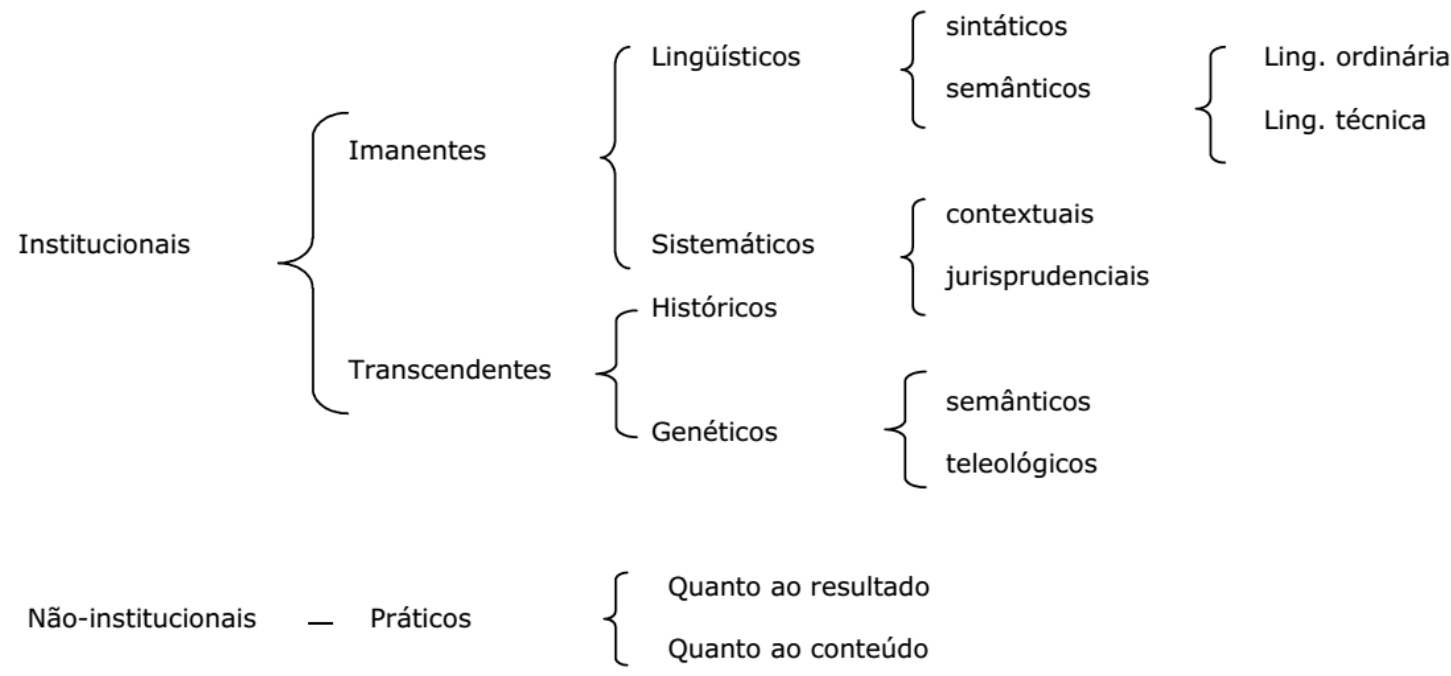

De acordo com o autor, os argumentos institucionais seriam aqueles que são determinados pela atividade institucional, isto é, pelos Poderes Legislativo, Executivo e Judiciário, estando assim referidos no ordenamento jurídico. Por encontrarem apoio no ordenamento, afirma o autor, tais argumentos teriam maior capacidade de objetivação. De outro lado, os argumentos não institucionais não se fundamentam no ordenamento, mas antes derivam do apelo a um sentimento de justiça eventualmente invocado na interpretação. Por esse motivo, possuem menor capacidade de objetivação do que os argumentos institucionais.

Dentre os argumentos institucionais, ensina ÁvILA, é possível distinguir os argumentos imanentes e os transcendentes. Os imanentes seriam aqueles que podem ser construídos a partir do ordenamento jurídico vigente, tendo em vista a sua linguagem textual e contextual e também seus valores e sua estrutura. Por sua vez, os argumentos transcendentes são aqueles que não têm uma relação direta com o ordenamento jurídico vigente, mas tratam de aspectos da sua formação ou do significado de dispositivos que ele antes continha ${ }^{93}$.

Os argumentos imanentes se dividem em linguísticos e sistemáticos, sendo que os primeiros dizem respeito ao significado do dispositivo (semântico ou sintático, sendo que, no

\footnotetext{
92 ÁVILA, Humberto. Argumentação Jurídica e a Imunidade do Livro Eletrônico. Revista Diálogo Jurídico, Ano I, vol. I, $\mathrm{n}^{\circ}$ 5, agosto 2001, pp. 6 e 7. Documento disponível no endereço eletrônico: http://www.direitopublico.com.br/pdf_5/dialogo-juridico-05-agosto-2001-humberto-avila.pdf, acessado em $05 / 12 / 2014$.

${ }^{93}$ Ibidem, pp. 7 e ss.
} 
primeiro caso, podem referir à linguagem ordinária ou à linguagem técnica), ao passo que os últimos decorrem da interpretação do preceito em sua relação com o ordenamento jurídico.

Segundo ÁvilA, os argumentos sistemáticos podem ser contextuais, caso em que a norma deve ser considerada como inserida em um sistema jurídico, sendo que tal sistema deve ser levado em conta na atividade de interpretação. São exemplos desse tipo os argumentos topográficos, os argumentos de constância terminológica e os de estudo da função da regra no sistema jurídico (sua teleologia). Ou podem ser argumentos jurisprudenciais, que têm em vista as decisões já proferidas pelo Poder Judiciário acerca do preceito em questão ${ }^{94}$.

Os argumentos transcendentes podem ser históricos ou genéticos. Ambos levam em conta a origem do preceito. No entanto, o argumento histórico diz respeito à forma como o problema vem sendo regulado ao longo do tempo, tratando de textos normativos anteriores que tenham um âmbito de aplicação semelhante ao da norma interpretada. Por sua vez, o argumento genético trata de elementos não normativos que deram origem à norma, tais como discussões parlamentares, projetos de lei e exposições de motivos, buscando aferir a vontade do legislador através da análise do significado que ele atribuiu a uma expressão (argumento genético semântico-subjetivo) e a finalidade que buscou atingir (argumento teleológico subjetivo $)^{95}$.

É necessário aqui deixar clara a distinção entre o argumento sistemáticoteleológico e o argumento genético-teleológico, que não se confundem. Enquanto o primeiro busca a finalidade da norma no próprio ordenamento jurídico, o segundo busca a finalidade pensada pelo legislador, com base em elementos externos, tais como a exposição de motivos.

Por fim, os argumentos não institucionais têm índole prática e levam em consideração fatores políticos, econômicos ou éticos. Por serem argumentos que não se referem ao ordenamento, direta ou indiretamente, são mais subjetivos e assim podem ser manipulados por maior facilidade. Dentre os argumentos não institucionais podemos citar aqueles que fazem referência às consequências políticas ou econômicas de uma decisão.

Frise-se, no entanto, que o aplicador do Direito não pode considerar livremente tais argumentos, atribuindo preponderância a uns sobre os outros em virtude de meras convicções pessoais. A escolha de um argumento e, pois, a tomada de decisão devem estar devidamente fundamentadas, a fim de que possam ser intersubjetivamente controladas.

\footnotetext{
${ }^{94}$ Ibidem, pp. 9 e ss.

95 Ibidem, pp. 17 e ss.
} 
É o que também salienta ÁvILA ${ }^{96}$, para quem o discurso do intérprete deve ser coerente com os usos linguísticos, com os métodos adotados e os argumentos e as doutrinas que embasaram sua interpretação. Através de um discurso coerente é possível controlar a interpretação, a fim de verificar se ela é consentânea com o ordenamento jurídico em questão.

Portanto, reconhecendo que a interpretação é sempre necessária e que corresponde a uma construção de sentido, o que nos cabe avaliar é a sua legitimidade, no que diz respeito à sua extensão e aos seus objetivos. Nesse contexto, a metodologia oferece mecanismos de controle sobre a plausibilidade dos juízos decisórios, garantindo sua objetividade ${ }^{97}$.

Estamos com ÁvILA quando afirma que os argumentos expostos acima não possuem todos o mesmo peso na interpretação jurídica, sendo possível traçar uma hierarquia entre eles. Frise-se que não se trata de uma hierarquia rígida, eis que o peso de determinado argumento depende das circunstâncias do caso em análise e também do ordenamento jurídico em que se insere o preceito a ser interpretado. Outrossim, os argumentos em tela estão relacionados uns com os outros, o que impede o estabelecimento de uma hierarquia rígida ${ }^{98}$.

Ainda assim, afirma Ávila que, no ordenamento jurídico brasileiro, é possível conferir precedência aos argumentos linguísticos e sistemáticos, visto que eles são imanentes ao ordenamento. Com efeito, o argumento linguístico é de extrema importância, eis que a interpretação está limitada pelo sentido possível do texto. Por sua vez, os argumentos sistemáticos são também fundamentais, eis que nenhum dispositivo pode ser interpretado de forma isolada, mas deve ser visto sempre em face do sistema jurídico em que se insere. Ademais, no exame dos argumentos sistemáticos, deve-se prestigiar o sentido que seja mais consentâneo com o princípio constitucional subjacente ao dispositivo interpretado. Atribuindo maior peso aos argumentos imanentes, busca-se assim prestigiar a separação dos poderes e a segurança jurídica, já que se referem ao ordenamento vigente. Depois desses argumentos podem ser considerados os argumentos históricos, os genéticos e, ao final, os práticos ${ }^{99}$.

Frise-se que, por não se tratar de uma hierarquia rígida, é possível que os argumentos que a princípio teriam peso superior sejam superados por outros de peso inferior, desde que o intérprete encontre fundamentos bastantes para tanto. Assim, o que a hierarquia faz é conceder maior peso argumentativo a determinados elementos, fazendo com que a carga de argumentação necessária para superá-los seja maior. Não impede, contudo, tal superação.

\footnotetext{
96 ÁVILA, Humberto. Função da Ciência do Direito Tributário: do Formalismo Epistemológico ao Estruturalismo Argumentativo. Revista Direito Tributário Atual, no 29, 2013, p. 195.

97 Também nesse sentido: NEVES, A. Castanheira. Interpretação Jurídica, in Digesta, pp. 340-341.

98 ÁVILA, Humberto. Argumentação Jurídica e a Imunidade do Livro Eletrônico, pp. 19 e ss.

${ }^{99}$ Ibidem, pp. 24 e ss.
} 
Pois bem. Analisada a interpretação jurídica e estabelecidas as premissas deste trabalho no que diz respeito à linguagem e ao papel da interpretação, cumpre agora avaliar se todas as conclusões aqui expostas podem ser aplicadas à interpretação das normas tributárias e, particularmente, às regras de imunidade tributária, ou se, ao contrário, tais normas possuem alguma peculiaridade que determine a utilização de métodos específicos de interpretação. 


\subsection{Interpretação e o Direito Tributário.}

\subsubsection{As teorias tradicionais sobre a interpretação do Direito Tributário.}

A interpretação do Direito Tributário também já suscitou e continua a suscitar inúmeras controvérsias, tendo se consagrado, na doutrina tradicional, três orientações no que tange aos métodos de interpretação aplicáveis às normas tributárias: o chamado in dubio pro fisco, o in dubio contra fiscum e a interpretação rígidas e estrita das normas tributárias ${ }^{100}$.

A interpretação a favor do Fisco, também denominada in dubio pro fisco, correspondia à ideia de que, nos casos em que o sentido da lei tributária não fosse evidente, esta deveria ser entendida do modo mais favorável à entidade de cobra o tributo, o Estado.

Essa orientação ganhou força em Roma, eis que, no período clássico, eram concedidos diversos privilégios ao Erário e, no período imperial, os decretos do Imperador determinavam que o juiz deveria julgar a causa sempre do modo mais favorável ao Fisco.

Segundo VANONI, foram desenvolvidas diversas justificativas para amparar essa posição. Uma delas baseava-se na regra do Direito Romano segundo a qual, nos casos em que o juiz, por culpa ou dolo, decidisse a favor do obrigado e contra o Fisco, considerava-se que ele cometia um delito grave, impondo assim uma interpretação sempre a favor do Fisco ${ }^{101}$.

Outro argumento bastante utilizado pelos defensores dessa corrente era o de que a interpretação favorável ao Fisco era sempre a interpretação favorável à causa do imposto, a qual seria uma causa de utilidade pública. Assim, o juiz que julgasse a favor do Erário beneficiaria a todos, eis que o tributo é voltado à consecução do interesse público, ao passo que o juiz que julgasse a favor do contribuinte prejudicaria todos os demais contribuintes.

Por fim, alegava-se que não caberia ao juiz criticar as leis votadas pelo Parlamento, mas somente aplicá-las, fazendo uso de "critérios estritamente fiscais".

Por sua vez, os defensores do chamado in dubio contra fiscum manifestavam-se no sentido oposto, isto é, afirmavam que, em caso de dúvida quanto ao sentido das leis tributárias, a interpretação a ser adotada deveria ser a mais favorável ao contribuinte.

Esse critério de interpretação é atribuído ao adágio de MODESTINO, segundo o qual "non puto delinquere eum qui in dubiis quaestionibus contra fiscum facile responderit".

\footnotetext{
${ }^{100}$ A origem de cada uma dessas orientações é detalhada por VANONI, Ezio. Natureza e Interpretação das Leis Tributárias, pp. 13 e ss.

${ }^{101}$ Ibidem, pp. 42-43.
} 
Referido adágio pode ser traduzido pela ideia de que nenhuma culpa poderia recair sobre aquele que houvesse decidido nos casos de dúvida contra o interesse do Fisco ${ }^{102}$.

Porém, o surgimento do enunciado de Modestino no Direito Romano só pode ser adequadamente compreendido se analisado o contexto histórico em que ele se inseria.

Com efeito, como visto nos capítulos anteriores, o tributo provincial romano era considerado odioso pela população, tendo em vista que ele era cobrado de forma arbitrária e excessiva. Ademais, não havia uma distinção clara entre o caixa do Imperador e o caixa do Estado, o que conduzia à impressão de que as receitas obtidas com a arrecadação do tributo não se voltavam ao bem comum, mas sim à satisfação dos interesses do Imperador ${ }^{103}$.

Foi em resposta a tal cenário que se desenvolveram os estudos dos juristas romanos, que tinham como objetivo fixar limites à aplicação das leis fiscais, evitando assim o arbítrio. É nesse contexto, portanto, que se insere o preceito de MoDESTINO citado acima, como instrumento de reação à forma de cobrança de tributos então adotada pelo Fisco ${ }^{104}$.

Diante disso já resta claro que o preceito de ModEstino não possuía uma aplicação generalizada, a significar que todo o Direito Romano deveria ser interpretado da maneira mais favorável ao contribuinte. Tratava-se apenas de uma tentativa de traçar limites à aplicação das leis tributárias, que, naquela época, incidiam de forma quase discricionária.

Isso explica as razões pelas quais o referido adágio continuou a ter relevância nos séculos que sucederam ao Império Romano, como forma de contenção da atividade fiscal.

Assim, no período feudal (séculos IX a XI), o tributo conservou as suas características de odiosidade, justificando a adoção do in dubio contra fiscum. Já na época das comunas (séculos XI a XV), passam a ser desenvolvidas novas teorias com o objetivo de conferir maior racionalidade à tributação, afastando-se a discricionariedade, sendo exemplo disso os trabalhos de TOMÁs DE AQUINO, que buscou desenvolver uma doutrina da tributação segundo a qual o tributo era uma imposição voltada à obtenção do bem comum, de modo que o imposto que não fosse exigido para fins de utilidade pública seria injusto e não obrigaria ${ }^{105}$.

No entanto, tendo em vista que tais estudos eram ainda embrionários, a jurisprudência continuou aplicando o preceito de MODESTINO, havendo autores que

\footnotetext{
102 GRIZIOTTI, Benvenuto. Principios de Politica, Derecho y Ciencia de la Hacienda. Tradução para o espanhol de Enrique R Mata. Madri: Reus, 1935, pp. 253-254.

${ }^{103}$ VANONI, Ezio. Natureza e Interpretação das Leis Tributárias, pp. 18-21.

${ }^{104}$ Ibidem, pp. 22-23.

105 Ibidem, pp. 25-27.
} 
defendiam que o in dubio contra fiscum fosse aplicado nas matérias em que houvesse dúvida e a prova não fosse plena, adotando-se a interpretação mais favorável ao contribuinte ${ }^{106}$.

Com a eclosão da Revolução Francesa e o início do século XVIII, ganham força as ideias de reforma tributária. Assim, os estudos doutrinários passam cada vez mais a analisar o tributo não como imposição odiosa ou arbitrária, mas como um dever do cidadão e um meio para a obtenção dos recursos necessários ao custeamento dos serviços públicos.

Assim é que o critério do in dubio contra fiscum começa a perder sua força, uma vez que ele foi criado em um contexto específico, como forma de coibir as arbitrariedades então praticadas pelo Fisco, visto que, naquela época, não havia regras voltadas à garantia do direito dos contribuintes ou uma teoria que pudesse conferir racionalidade à tributação.

No entanto, com o desenvolvimento dessas teorias e com a regulamentação cada vez mais intensa da relação tributária, tal critério não mais se justificava, eis que os contribuintes já dispunham de outros mecanismos para a contenção do poder do Estado.

Diante disso, com o passar dos séculos, consolidou-se o entendimento de que o Direito Tributário não poderia ser interpretado de acordo com critérios apriorísticos, a favor do Fisco ou do contribuinte, tais como o in dubio contra fiscum ou o in dubio pro fisco.

Nesse contexto, surge uma nova teoria sobre a interpretação do Direito Tributário, segundo a qual as leis sobre matéria tributária deveriam ser interpretadas sempre de modo rígido e estrito. Afirmavam os seus defensores que não poderiam ser aplicados ao Direito Tributário os mesmos métodos de interpretação utilizados nos outros ramos do Direito.

Segundo VANONI, os principais argumentos utilizados para fundamentar essa posição eram os de que: (i) a lei tributária seria restritiva e limitadora de direitos; (ii) a lei tributária representaria uma exceção aos princípios gerais do Direito e estaria submetida às regras de hermenêutica aplicáveis às leis excepcionais; e (iii) a lei tributária seria mais taxativa do que as leis dos outros ramos e, portanto, deveria ser aplicada com precisão ${ }^{107}$.

É possível encontrar reflexos dessa orientação na doutrina brasileira. A título de exemplo, PONTES DE MiRANDA entendia que a interpretação das leis tributárias não poderia ser feita utilizando-se dos mesmos métodos de interpretação das leis comuns. Afirmava o autor que a única fonte da obrigação tributária era a lei e que essa deveria ser entendida de modo rígido e estrito, uma vez que seria da natureza das leis tributárias a sua precisão "pela

\footnotetext{
106 Ibidem, p. 37.

${ }^{107}$ Ibidem, p. 46-47.
} 
taxatividade e pelos elementos matemáticos de que se tem de lançar mão para atingir o patrimônio das pessoas que são sujeitas às regras jurídicas tributárias" ${ }^{\text {"108 }}$.

Ocorre que referida orientação parte de premissas equivocadas, eis que o Direito Tributário não possui qualquer peculiaridade que imponha uma interpretação rígida ou estrita.

Com efeito, o argumento de que as leis fiscais seriam restritivas e limitadoras de direitos e que teriam caráter excepcional não se sustenta, uma vez que a limitação à propriedade privada, trazida pela tributação, não tem caráter excepcional, mas é apenas mais um instrumento para a convivência dos indivíduos em sociedade. De fato, é apenas através da regulamentação do direito de propriedade e da instituição de tributos voltados ao custeio dos gastos públicos que se pode falar na existência do Estado. Assim, a lei tributária não é mais restritiva ou limitadora que outras leis e sequer tem caráter excepcional. Ao contrário, ela é um instrumento necessário e natural em um Estado de Direito que deve custear seus gastos ${ }^{109}$.

Ademais, a ideia de excepcionalidade pressupõe que as leis tributárias sejam uma exceção a leis ditas "gerais", às quais elas se contraporiam. No entanto, quais leis gerais seriam estas? A argumentação claramente não se sustenta. Poder-se-ia falar, no máximo, em leis tributárias como leis especiais (e não excepcionais), no sentido de que regulam um tipo específico de relação jurídica (é dizer, a relação entre Fisco e contribuinte). Porém, tal natureza também não fundamentaria a adoção de um método específico de interpretação ${ }^{110}$.

Por fim, afirmam os defensores dessa tese que as leis tributárias seriam mais taxativas e que, portanto, deveriam ser aplicadas com precisão. Ora, como já visto nos capítulos anteriores, todos os textos jurídicos estão vertidos em linguagem e, consequentemente, todos estão sujeitos aos problemas decorrentes da imprecisão da linguagem. Assim, o intérprete pode atribuir às leis tributárias, assim como às leis de outros ramos do Direito, inúmeros sentidos, o que afasta a ideia de total precisão ou taxatividade.

\footnotetext{
108 MIRANDA, Pontes. Comentários à Constituição de 1967, p. 382.

109 Veja nesse sentido SOUSA, Rubens Gomes de. Compêndio de Legislação Tributária. São Paulo: Resenha Tributária, 1975, p. 53 e ss.; e VANONI, Ezio. Natureza e Interpretação das Leis Tributárias, p. 140. No mesmo sentido o magistério de DINO JARACH. Afirma o autor que, em um Estado Democrático e de Direito, onde os impostos são consentidos pelo povo e a obrigação tributária nasce da lei como fonte formal e material e o tributo representa uma relação jurídica e não uma relação de poder e em que o devedor e o credor estão em uma relação de igualdade frente a lei que cria a obrigação, não é mais possível sustentar que a lei tributária é limitadora de direitos ou tem caráter odioso (in Curso Superior de Derecho Tributario. Edição nova atualizada. Buenos Aires: Liceo Profesional Cima, 1969, pp. 262-263).

${ }^{110}$ É o que também salienta PINTO, Carlos Alberto A. de Carvalho. Hermenêutica das Leis Fiscais. São Paulo: Prefeitura do Município de São Paulo, 1941, p. 15.
} 
Tendo em vista as críticas expostas acima, hoje prevalece o entendimento de que não podem ser aplicados critérios apriorísticos à interpretação do Direito Tributário e que as leis tributárias devem ser interpretadas segundo os mesmos métodos aplicados a outras leis ${ }^{111}$.

No entanto, é importante salientar que ainda é possível encontrar na doutrina reflexos dessa concepção de interpretação rígida do Direito Tributário, que atribui especial relevância à legalidade e tem profundos impactos no estudo de questões como a possibilidade de interpretação extensiva e de analogia em matéria tributária, como veremos a seguir.

\subsubsection{A interpretação no Direito Tributário Brasileiro.}

Como visto no item acima, prevalece hoje na doutrina brasileira o entendimento de que as leis tributárias podem ser interpretadas segundo os mesmos métodos aplicados aos outros ramos do Direito, não sendo possível utilizar critérios apriorísticos na interpretação de tais leis, tais como os critérios do in dubio contra fiscum ou do in dubio pro fisco.

No entanto, seria possível atribuir precedência a certos métodos de interpretação no Direito Tributário brasileiro? Ademais, haveria limites aos métodos empregados na interpretação das leis fiscais, como, por exemplo, nos casos de desonerações tributárias?

O Código Tributário Nacional brasileiro trouxe diversos dispositivos sobre a interpretação no capítulo intitulado "Interpretação e Integração da Legislação Tributária".

A fixação, por meio de lei, de regras de interpretação, na realidade, não constitui nenhuma novidade no Direito brasileiro ou no Direito comparado, sendo possível falar, já no Direito Romano, na fixação de regras voltadas à instituição de proibições de interpretar. Assim, Constantino reservou para si o exame da interpretação interposta entre a equidade e o Direito, Valentiniano e Marciano estabeleceram regras segundo as quais cabia ao Imperador

\footnotetext{
${ }^{111}$ SOUSA, Rubens Gomes de. Compêndio de legislação tributária, pp. 79 e ss.; FALCÃO, Amílcar de Araújo. Introdução ao Direito Tributário. $6^{a}$ ed. Rio de Janeiro: Forense, 1999, p. 62; MACHADO, Hugo de Brito. A Interpretação e o Direito Tributário Brasileiro. In: NASCIMENTO, Carlos Valder do (org.). Interpretação no Direito Tributário. São Paulo: Revista dos Tribunais, 1989, p. 32; BECKER, Alfredo Augusto. Teoria Geral do Direito Tributário. $5^{a}$ ed. São Paulo: Noeses, 2010, p. 117; BEISSE, Heinrich. Interpretação. In: NOGUEIRA, Ruy Barbosa (coord.). Estudos Tributários em Homenagem à Memória de Rubens Gomes de Sousa, p. 46; TORRES, Ricardo Lobo. Normas de Interpretação e Integração do Direito Tributário. $4^{\mathrm{a}}$ ed. Rio de Janeiro: Renovar, 2006, pp. 48-49; VANONI, Ezio. Natureza e Interpretação das Leis Tributárias, p. 181; JARACH, Dino. Finanzas Públicas y Derecho Tributario. $3^{a}$ ed. Buenos Aires: Abeledo-Perrot, 1999, p. 393; BERLIRI, Antonio. Corso Istituzionale di Diritto Tributario. Milão: A. Giuffrè, 1965, p. 15; GIANNINI, Achille Donato. Instituzioni di Diritto Tributario. $7^{a}$ ed. Milão: A. Giuffrè, 1956, pp. 25-26; NOGUEIRA, Ruy Barbosa. Da Interpretação e da Aplicação das Leis Tributárias. $2^{\mathrm{a}}$ ed. São Paulo: Revista dos Tribunais, 1965, p. 113.
} 
explicar as obscuridades e mitigar o rigor das leis e Justiniano proibiu interpretações, determinando que os juízes deveriam ouvir o Imperador em caso de dúvidas ${ }^{112}$.

Da mesma forma, na França, a ordonnance civil pour la reformation de la justice, de 1667, proibia a interpretação, facultando a consulta ao rei, e o référé législatif determinava que os juízes devessem consultar o Legislativo sempre que fosse necessário interpretar a lei.

No Brasil, também podemos constatar uma longa tradição de instituição de regras jurídicas voltadas a proibir ou, ao menos, restringir a interpretação jurídica.

Um exemplo claro disso pode ser encontrado na Lei da Boa Razão, de 18.08.1769, que tinha como objetivo "precaverem com sábias providências as interpretações abusivas, que ofendem a Majestade das Leis; desautorizam a reputação dos Magistrados; e tem perplexa a justiça dos Litigantes”. Referida lei trazia inúmeras regras acerca da interpretação dos textos jurídicos, como seu item 7, que previa que os advogados que fizessem uso de interpretações equivalentes a "raciocínios frívolos e ordenados mais a implicar com sofismas as verdadeiras Disposições das Leis" e que agissem com dolo fossem multados, pela primeira vez em cinquenta mil réis e em seis meses de suspensão, pela segunda vez em privação dos graus que tivessem da Universidade e pela terceira em cinco anos de degredo para Angola, se fizessem assinar clandestinamente suas alegações por quatro pessoas, o que demonstra as pesadas restrições a que estava sujeita a interpretação jurídica.

Já no século XX podemos mencionar a Lei de Introdução ao Código Civil Brasileiro, inserida pelo Decreto-Lei $\mathrm{n}^{\circ}$ 4.657/1942 (atualmente denominada Lei de Introdução às Normas do Direito Brasileiro) que, embora não buscasse restringir a interpretação tal como o diploma acima, também trouxe inúmeras regras sobre a matéria.

Assim, seu art. $4^{\circ}$ prevê que, em caso de omissão, o juiz decidirá de acordo com a analogia, os costumes e os princípios gerais de direito e o art. $5^{\circ}$ determina que, na aplicação da lei, o juiz atenderá aos fins sociais a que ela se dirige e às exigências do bem comum.

Diante disso, cumpre perquirir: caberia ao legislador fixar regras sobre a interpretação jurídica? Quando este o faz, tais regras tem o caráter de vincular a interpretação?

A instituição de regras sobre a interpretação de textos jurídicos tem recebido críticas de muitos juristas, dentre as quais as a de que (i) a interpretação é assunto exclusivamente doutrinário e científico e não deve ser regulada pela legislação, (ii) a interpretação não seguiria regras universais e invariáveis e que, portanto, possam ser positivadas, (iii) seria impossível prever na lei critérios de interpretação para todos os casos

${ }^{112}$ Uma análise exaustiva das regras de interpretação do Direito brasileiro e do Direito comparado é feita por TORRES, Ricardo Lobo. Normas de Interpretação e Integração do Direito Tributário, pp. 2 e ss. 
possíveis, (iv) ao legislador caberia apenas instituir a regra, sendo que a maneira de compreendê-la caberia ao juiz e estaria condicionada pelo contexto histórico em que este se insere, podendo passar por alterações a depender de tal contexto, dentre outras críticas ${ }^{113}$.

Não obstante tais críticas, alguns autores defendem que as regras de interpretação fixadas por meio de lei têm força vinculante e limitam a atuação do julgador.

Nesse sentido, afirma CARlos MAXIMILIANO que as regras de hermenêutica inseridas na lei têm a mesma força compulsória dos demais preceitos legais. No entanto, o autor ressalta que tais regras também estão sujeitas à interpretação, que pode variar de acordo com as condições sociais, alterando assim com o passar do tempo sua aplicabilidade ${ }^{114}$.

Por outro lado, diversos autores sustentam que não cabe ao legislador estabelecer normas de interpretação e que, quando tais regras são instituídas em lei, estas devem ser vistas como meras orientações ao intérprete, não tendo o condão de vincular a sua atividade ${ }^{115}$.

Nesse sentido afirma LUIS RECASENS SiCHES que, se o legislador estabelece de que forma os juízes devem interpretar a lei, tais palavras devem ser tidas como inoperantes, tendo em vista que a função jurisdicional se distingue da função legislativa, e a primeira só pode ser exercida pelo órgão que tem competência para tanto ${ }^{116}$.

$\mathrm{E}$, de fato, a atividade de interpretação realizada pelo julgador não pode ser limitada pelo Poder Legislativo. Ademais, o estabelecimento de regras de interpretação na maioria das vezes traduz uma tentativa por parte do legislador de impor uma ideologia, eis que, como já visto acima, o poder sobre a interpretação retrata uma disputa pelo domínio do Direto. Desse modo, a fixação de regras limitativas da atividade interpretativa pode visar, em última análise, reduzir os poderes do Judiciário, dando precedência ao Poder Legislativo ${ }^{117}$.

\footnotetext{
113 Tais críticas são sumarizadas por MAXIMILIANO, Carlos. Hermenêutica e Aplicação do Direito. $19^{\mathrm{a}}$ ed. Rio de Janeiro: Forense, 2001, p. 78.

${ }^{114}$ MAXIMILIANO, Carlos. Hermenêutica e Aplicação do Direito, p. 80.

115 Vide, dentre outros, os seguintes autores: NASCIMENTO, Carlos Valder do. Interpretação no Direito Tributário. In: NASCIMENTO, Carlos Valder do (org.). Interpretação no Direito Tributário, p. 58; NOGUEIRA, Ruy Barbosa. Interpretação e Integração da Legislação Tributária, p. 7; e BORGES, Souto Maior. Teoria Geral da Isenção Tributária, p. 129. No mesmo sentido ROBERTO DE RUGGIERO, para quem "não cumpre ao legislador ditar normas interpretativas das leis e quando as dita, como sucede entre nós, elas são simples diretrizes, não obrigatórias para os juízes e que, assim, quase que não têm praticamente valor algum" (in Instituições de Direito Civil. Vol. I. Tradução da $6^{\mathbf{a}}$ edição italiana por Paolo Capitanio. Campinas: Bookseller, 1999, p. 181).

${ }^{116}$ SICHES, Luis Recasens. Tratado General de Filosofia del Derecho. 19ª ed. México: Porrúa, 2008, p. 627.

117 É o que também salienta LUIS LEGAZ Y LACAMBA. Segundo o autor, não é aconselhável que a lei estabeleça o método interpretativo a ser adotado pelo julgador, eis que o legislador não pode impor sua ideologia à posteridade (in Filosofía del Derecho. Barcelona: Bosch, 1953, p. 418).
} 
Diante disso, as regras de interpretação veiculadas pelo Código Tributário Nacional brasileiro não tem o condão de obrigar o intérprete, que está livre para adotar os métodos interpretativos que entender mais adequados para solucionar os casos concretos.

De todo modo, passaremos a analisar algumas das regras inseridas no Código, na medida em que trazem à tona importantes discussões sobre a utilização de alguns expedientes específicos na interpretação das leis fiscais, tais como a interpretação extensiva e a analogia.

Prescreve o art. 108 do CTN:

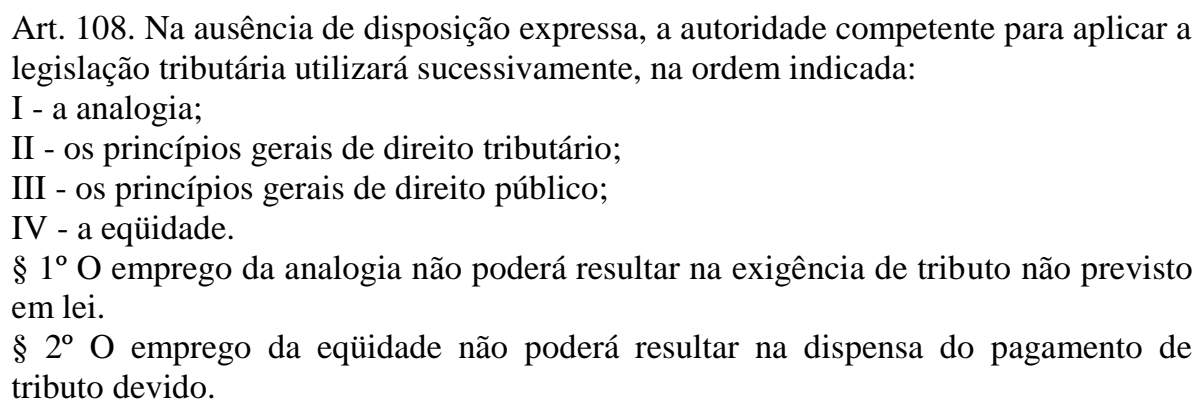

Verifica-se nesse artigo uma tentativa de limitar os métodos de interpretação aplicáveis ao Direito Tributário. Essa conclusão é confirmada pela análise dos trabalhos da Comissão Especial responsável pelo projeto do $\mathrm{CTN}$, a qual registrou que estavam sendo enumerados os critérios supletivos de interpretação visando "afastar o recurso a métodos e processos de hermenêutica incompatíveis com a natureza e as finalidades próprias do Direito Tributário" $" 118$.

O art. 108 do CTN determina que, na ausência de disposição expressa, o aplicador da legislação tributária poderá fazer uso da analogia, dos princípios gerais de Direito Tributário, dos princípios gerais de Direito Público e da equidade. No entanto, ressalta que a analogia não poderá resultar na exigência de tributo não previsto em lei e que, por outro lado, a equidade não poderá resultar na dispensa do pagamento de tributo devido.

A orientação adotada pelo CTN no art. 108, $\S 1^{\circ}$, reflete a posição majoritária da doutrina, segundo a qual a analogia pode ser aplicada às normas de Direito Tributário formal ou administrativo, mas não pode autorizar a criação de tributo não previsto em lei ${ }^{119}{ }^{120}$.

\footnotetext{
118 Trabalhos da Comissão Especial do Código Tributário. Rio de Janeiro: IBGE, 1954, p. 181.

${ }^{119}$ Com efeito, prevalece na doutrina estrangeira e na doutrina brasileira o entendimento de que a analogia não pode ser aplicada às leis tributárias substanciais, isto é, que versam sobre o tributo, seu fato gerador, base de cálculo, sujeito passivo, etc. Tal entendimento baseia-se no princípio da legalidade, ao argumento de que o tributo deve decorrer de expressa previsão legal. Nesse sentido vale conferir o magistério de GIANNINI (in Instituzioni di Diritto Tributario, p. 26), para quem a norma que disciplina o tributo não é suscetível de interpretação analógica, mas pode ser objeto de interpretação extensiva, pois nesse caso não se trata de aplicar o
} 
Veja-se, como exemplo dessa posição doutrinária, o escólio de RUY BARBOSA NoGUEIRA, para quem a analogia poderia ser aplicada no campo formal e nos procedimentos de aplicação da lei tributária, mas não poderia ser utilizada em relação às normas tributárias substantivas, isto é, criadoras, modificadoras ou extintivas de obrigações fiscais ${ }^{121}$.

Para o autor, esse entendimento seria uma decorrência do princípio da legalidade, segundo o qual o tributo só pode ser criado através de lei. Assim, afirma RUY BARBOSA NoGUEIRA que a legislação deve conter uma "descrição prévia de todos os elementos que a lei exige para a construção da plataforma sobre que poderá assentar o imposto e, mais ainda, que se precisa constatar se na prática são rigorosamente os mesmos elementos previamente descritos na lei que estão sendo atingidos". Conclui que, para que surja a obrigação tributária, é necessário que "à semelhança de um espelho a lei reflita o retrato da relação de fato"122.

tributo a uma situação não prevista em lei, mas sim a uma situação compreendida no real conteúdo da norma. No mesmo sentido: ARAÚJO, Petrônio Baptista. Impôsto sôbre a Transmissão da Propriedade: trabalho realizado para o Instituto de Direito Público e Ciência Política. Rio de Janeiro: FGV, 1954, p. 97. Também se manifestaram contra a aplicação da analogia para autorizar a exigência de tributo não previsto em lei os seguintes autores: BECKER, Alfredo Augusto. Teoria Geral do Direito Tributário, p. 141; VILLEGAS, Héctor Belisario. Curso de Finanzas, Derecho Financiero y Tributario. $8^{\mathrm{a}}$ ed. Buenos Aires: Astrea, 2002, p. 228; BERLIRI, Antonio. Corso Istituzionale di Diritto Tributario, pp. 20-21; MORAES, Oswaldo de. A Analogia no Direito Tributário Brasileiro. São Paulo: Revista dos Tribunais, 1965, p. 102; VELLOSO, Andrei Pitten. Analogia e Isonomia no Direito Tributário. Revista Tributária e de Finanças Públicas, v. 13, n. ${ }^{\circ} 62$, 2005, p. 8486; MACHADO, Hugo de Brito. A Interpretação e o Direito Tributário Brasileiro. In: NASCIMENTO, Carlos Valder do (org.). Interpretação no Direito Tributário, pp. 42-43; ÁVILA, Humberto. Sistema Constitucional Tributário, pp. 514 e ss.; FALCÃO, Amílcar de Araújo. Fato Gerador da Obrigação Tributária. $6^{\mathbf{a}}$ ed. Rio de Janeiro: Forense, 1997, pp. 18 e ss.; e JARACH, Dino. Curso Superior de Derecho Tributario, pp. 270-271. Afirma JARACH que o princípio da legalidade exclui a analogia como forma de aplicar um imposto a caso não previsto em lei, eis que isso significaria aplicar um imposto quando a lei, através dos representantes do povo, não expressou a vontade de submeter determinados direitos ou atos ao gravame. Cumpre também mencionar a posição de RUBENS GOMES DE SOUSA, para quem a analogia não pode ser usada como método aplicativo do Direito Tributário, eis que violaria o princípio da legalidade. Assim, conclui, citando BLUMENSTEIN, que se a lei não diz então "não há norma e, portanto, não há lugar para uma interpretação integrativa, como seria a analógica" (in Normas de Interpretação no Código Tributário Nacional, in Interpretação no Direito Tributário. São Paulo: Saraiva, 1975, pp. 376-377). No mesmo sentido ALBERTO XAVIER, para quem o Direito Tributário é modelado pelo princípio da taxatividade e, por esse motivo, a capacidade de valoração e decisão dos órgãos de aplicação do Direito está fortemente limitada, sendo vedado o recurso à analogia. Argumenta que "a aplicação da norma tributária não pode ser deduzida de toda a ordem jurídica, antes deverá ater-se à clara formação legal, que em si mesma contém um indispensável critério de decidir" e que a tipologia taxativa tributária opera "como uma plenitude lógica da ordem a que se refere, tornando-a, do mesmo passo, completamente livre de lacunas" (in Os Princípios da Legalidade e da Tipicidade da Tributação. São Paulo: RT, 1978, pp. 87-88). Em sentido favorável à aplicação da analogia em matéria tributária vale mencionar o escólio de GRIZIOTTI, Benvenuto. Principios de Politica, Derecho y Ciencia de la Hacienda, pp. 257-258, e VANONI, Ezio. Natureza e Interpretação das Leis Tributárias, pp. 324 e ss.

${ }^{120}$ Frise-se que alguns autores, como ALFREDO AUGUSTO BECKER (in Teoria Geral do Direito Tributário, p. 139), distinguem a chamada analogia por compreensão da analogia por extensão. No primeiro caso a interpretação constataria a incidência de regra jurídica que já existia (o que corresponderia à noção de interpretação extensiva) e no segundo caso haveria a criação de regra jurídica nova (a analogia stricto sensu). Apenas a analogia por extensão seria inadmissível no Direito Tributário.

${ }^{121}$ NOGUEIRA, Ruy Barbosa. Da Interpretação e da Aplicação das Leis Tributárias, p. 112.

${ }^{122}$ Ibidem, pp. 101 e 116. 
Contudo, como vimos anteriormente, o texto de lei jamais poderá ser um reflexo exato dos fatos ocorridos na realidade, é dizer, jamais haverá uma correspondência exata entre os fatos e a previsão normativa, que permita que a aplicação do Direito seja uma mera atividade de subsunção mecânica. A interpretação e a aplicação do Direito, que não são atividades distintas, mas antes se confundem, consistem na compreensão do texto e na construção do seu sentido, havendo assim sempre um trabalho criador por parte do intérprete.

No entanto, a observação do autor é relevante na medida em que ressalta a importância do princípio da legalidade em nosso sistema tributário, consagrado em sede constitucional. Assim, se de um lado tal princípio não autoriza a conclusão de que a lei deva prever a relação tributária como um espelho (o que seria mesmo impossível, em qualquer ramo do Direito), o princípio da legalidade determina que a criação, a alteração e a exclusão do tributo dependem de lei e que tais leis possuem um sentido possível que não pode ser superado. De fato, caso pudéssemos aplicar a analogia para criar novos tributos, modificá-los ou afastar a sua incidência, de pouco valeria o princípio da legalidade em matéria tributária.

Sendo assim, as normas que estabelecem a incidência dos tributos, dispondo sobre os seus elementos essenciais, como fato gerador, base de cálculo e sujeito passivo, assim como as normas que afastam tal incidência (isenções) devem ser interpretadas nos limites do sentido possível, sendo inadmissível o emprego da analogia ou da redução teleológica.

O mesmo vale para os preceitos que fixam a competência tributária dos entes federados. Com efeito, como visto nos capítulos anteriores, a Constituição Federal brasileira trouxe uma rígida discriminação das competências tributárias, a fim de evitar que os entes da Federação exercessem poderes sobre as matérias atribuídas a outros entes, garantindo desse modo a manutenção do pacto federativo. Tal estrutura não é consentânea com a utilização do expediente analógico, que supera os limites do sentido possível dos termos empregados pela Constituição. Vale ressaltar que esse entendimento deve ser aplicado não apenas para as regras que concedem poder tributário, mas também para aquelas que limitam tal poder, isto é, as regras de imunidade tributária, visto que as primeiras e as últimas são o verso e o reverso da mesma medalha e atuam conjuntamente no desenho das competências tributárias.

De fato, esse é o entendimento mais consentâneo com a estrutura da Constituição brasileira e é também aquele que prestigia a segurança jurídica, garantindo que o contribuinte saberá em que situações poderá ser tributado e em quais estará imune ou isento do tributo. 
O Código também determina, em seu art. 111, que devem ser interpretadas "literalmente" as leis que versem sobre (i) a suspensão ou a exclusão do crédito tributário; (ii) a outorga de isenções; e (iii) a dispensa do cumprimento de obrigações tributárias acessórias.

Ensina GUASTINI que a expressão “interpretação literal” é geralmente utilizada para designar três coisas distintas ${ }^{123}$. Em primeiro lugar, interpretação literal pode equivaler a interpretação prima facie, no sentido de uma interpretação "intuitiva", que decorre dos conhecimentos linguísticos e das expectativas do intérprete. Contrapõe-se à interpretação prima facie aquela que é fruto da problematização do significado e de ulterior reflexão.

Em segundo lugar, a expressão pode ser entendida como interpretação não contextual ou acontextual, entendida como aquela que, para justificar o significado escolhido do texto (o seu significado “objetivo"), nada invoca além das regras de semântica e sintática da linguagem. Em contraponto, a interpretação contextual seria aquela que, para defender determinado significado, faz uso de elementos extratextuais, como os trabalhos preparativos.

Por fim, a expressão "interpretação literal" pode ser utilizada para referir-se à interpretação "não corretiva", isto é, a uma interpretação dita "declarativa", pela qual não se pode restringir ou estender o suposto significado "próprio", "natural” ou "objetivo" do texto normativo. Essa concepção geralmente está associada a uma teoria cognitivista da interpretação, pela qual o texto normativo teria um sentido intrínseco a ele incorporado.

Entretanto, como vimos nos capítulos anteriores, as palavras não possuem um sentido imanente, que possa ser revelado por uma interpretação dita "literal". Ademais, a interpretação prima facie, que não problematiza o significado do texto, assim como a interpretação não contextual, que leva em conta apenas os argumentos linguísticos, não é verdadeira interpretação, mas apenas uma etapa do processo interpretativo ${ }^{124}$. A interpretação, como compreendida neste trabalho, é um processo de construção do sentido, no qual podem ser levados em consideração diversos argumentos, além das regras de semântica e sintática, como a relação do dispositivo com as demais normas que compõem o ordenamento jurídico.

No entanto, poderíamos atribuir outro sentido à expressão "interpretação literal" empregada pelo art. 111 do CTN, que não esteja necessariamente atrelado a uma teoria cognitivista da interpretação. De fato, pode-se entender esse artigo como a determinar que a interpretação das isenções, assim como das leis que versem sobre a suspensão ou a exclusão do crédito tributário e a dispensa do cumprimento de obrigações tributárias acessórias, deva

${ }^{123}$ GUASTINI, Riccardo. Interpretare e Argomentare, pp. 95-97.

${ }^{124}$ Como leciona SOUTO MAIOR, não é possível cindir os processos gramatical e lógico de interpretação. Assim, determinar a interpretação literal, no sentido de interpretação meramente gramatical, é mutilar a interpretação ou suprimi-la (in Teoria Geral da Isenção Tributária, pp. 130-131). 
sempre se ater ao "âmbito nuclear" dos termos empregados por estes enunciados normativos, vedando assim não só a analogia como também a chamada interpretação extensiva.

E, de fato, esse é o entendimento majoritário da doutrina brasileira, no sentido de que as isenções devam ser interpretadas sempre de maneira "estrita" ou "restritiva" "125, sendo vedada a sua extensão a casos que não tenham sido expressamente mencionados pela lei ${ }^{126}$.

Um dos principais argumentos utilizados para sustentar essa posição é o de que as isenções são regras de caráter excepcional, na medida em que excluem determinadas pessoas ou bens do princípio da generalidade da tributação. Ademais, alega-se que as isenções seriam um privilégio ou uma renúncia ao poder tributário, de modo que o aplicador do Direito não poderia presumir que ela é mais ampla do que os termos expressos da lei ${ }^{127}$.

No entanto, como bem salienta SOUTO MAIOR, as isenções não são um privilégio, um favor ou uma liberalidade concedida à custa dos cofres do Estado. De fato, a tributação deve obedecer aos princípios da generalidade e da igualdade, de modo que a concessão de uma isenção deve estar devidamente fundamentada, não podendo ser um favor. Nesse ponto a observação de VANONI é exata ao afirmar que "a lei não abandona a regra geral por capricho, mas porque reconhece que aquela não leva em conta determinas exigências particulares" 128 .

Ademais, como bem acrescenta SoUTO MAIOR, caso considerássemos as isenções como um favor concedido pelo Estado, não poderia haver sequer um controle jurisdicional sobre elas, voltado à análise da sua compatibilidade material com o sistema jurídico ${ }^{129}$.

\footnotetext{
125 Vale ressaltar que os termos interpretação "restritiva" e "estrita" são muitas vezes empregados como sinônimos pela doutrina, em contraposição à noção de "interpretação extensiva" ou "ampliativa".

126 Nesse sentido afirma RUBENS GOMES DE SOUSA que as isenções concedidas por leis especiais constituem verdadeiros privilégios ou favores fiscais, sujeitos por isso mesmo a uma interpretação restritiva, de modo que as isenções tributárias só podem ser reconhecidas quando clara e expressamente consignadas em lei (in Lucros Extraordinários e Imposto de Renda: comentários ao decreto n. 15028 de 13 de março de 1944, em relação com a doutrina e a legislação do imposto de renda. São Paulo: Livraria Martins, 1944, p. 66). No mesmo sentido BERNARDO RIBEIRO DE MORAES, para quem a isenção é um favor concedido pela lei, uma renúncia do ente tributante, motivo pelo qual deveria ser interpretada de forma restrita, limitada. Assim, conclui que "não se pode estender a casos, figuras, hipóteses ou pessoas que não hajam sido clara e expressamente enunciados no dispositivo legal" e que "na interpretação da norma fisscal, que contém isenção, só se podem conhecer as franquias claras, expressas e inequivocamente mencionadas" (in Doutrina e Prática do Impôsto de Indústrias e Profissões, pp. 677-678). Vale mencionar também o escólio de CARLOS MAXIMILIANO, para quem não se presume o intuito de abrir mão de direitos inerentes à autoridade, de modo que a outorga da isenção deve ser feita de forma clara e não pode se estender além das hipóteses indicadas pelo texto (in Hermenêutica e Aplicação do Direito, p. 272). No mesmo sentido CELIO PEIXOTO DE AZEVEDO LOUREIRO, para quem as isenções impõem, por sua natureza, interpretação estrita ou restritiva (in Verbete Isenção Fiscal. In: SANTOS, J. M. de Carvalho (org.). Repertório Enciclopédico do Direito Brasileiro. Vol. 29. Rio de Janeiro: Borsoi, 1947, p. $350)$.

${ }^{127}$ Nessa linha, afirma GILBERTO DE ULHÔA CANTO que a isenção é uma renúncia ao poder tributário, de maneira que "não se deve presumir essa renúncia, aquilo, que seria um favor, uma autolimitação, além dos termos em que manifestada na lei" (in Temas de Direito Tributário. Vol. 3. Rio de Janeiro: Alba, 1964, p. 195). ${ }^{128}$ VANONI, Ezio. Natureza e Interpretação das Leis Tributárias, pp. 334-336.

${ }^{129}$ BORGES, Souto Maior. Teoria Geral da Isenção Tributária, pp. 62-63.
} 
Diante disso, SOUTO MAIOR e VANONI refutam o entendimento de que as isenções tributárias deveriam ser sempre interpretadas de maneira estrita e de que não admitiriam interpretação extensiva. Para SOUTO MAIOR, não há nenhum obstáculo de ordem lógica à aplicação da interpretação extensiva às leis excepcionais, visto que essas, assim como as demais normas jurídicas, devem ser interpretadas em toda a sua força de compreensão ${ }^{130 \_131}$.

Desse modo, o art. 111 do CTN só pode ser interpretado adequadamente como a querer dizer que as palavras utilizadas pelo texto normativo funcionam como um limite para a interpretação dos preceitos nele listados, de modo que o resultado da interpretação das regras de isenção está limitado ao sentido possível das palavras empregadas pela lei tributária.

Assim é que a interpretação das isenções não pode fazer uso da analogia, já que, em virtude do princípio da legalidade consagrado em nosso sistema tributário, a analogia não pode ser utilizada para criar, modificar ou excluir o tributo. No entanto, é admissível a interpretação extensiva desses preceitos, para alcançar situações que, embora não estejam no âmbito nuclear dos termos, estão de toda forma abarcadas pelo sentido possível do texto ${ }^{132}$.

\footnotetext{
${ }^{130}$ Ibidem, p. 122.

131 VANONI, Ezio. Natureza e Interpretação das Leis Tributárias, p. 324. Frise-se que esse autor admite inclusive a utilização da analogia na interpretação das regras de isenção tributária. Para VANONI, a analogia não cria novo direito, mas apenas revela o alcance de uma norma contida indiretamente na lei.

${ }^{132}$ Evidentemente, definir o que seja o "sentido literal possível" do texto também é papel da interpretação jurídica, o que faz com que, em certos casos, não haja uma distinção totalmente clara entre a analogia e a interpretação extensiva. Ademais, é importante observar que, muitas vezes, encontramos na jurisprudência brasileira decisões que afirmam realizar interpretação extensiva das leis tributárias, quando, na realidade, fazem uso da analogia, conferindo ao texto um sentido que claramente supera a literalidade dos seus termos.
} 


\subsection{Interpretação das Imunidades Tributárias.}

Como vimos nos capítulos anteriores, a interpretação de textos jurídicos não é apenas uma atividade de conhecimento ou de subsunção mecânica dos fatos à previsão normativa. Ao contrário, trata-se de uma atividade de construção de sentido, na qual podem ser empregados diversos argumentos, tais como argumentos linguísticos, sistemáticos, históricos e práticos, cada um deles possuindo um peso relativo na tomada de decisões.

O mesmo se dá no Direito Tributário. Assim, as normas tributárias podem ser interpretadas segundo os mesmos métodos utilizados em outros ramos do Direito, devendo ser afastados critérios apriorísticos como a interpretação favorável ao Fisco ou ao contribuinte.

Ocorre que as regras de imunidade não são apenas normas de Direito Tributário, mas normas constitucionais de Direito Tributário, eis que estão previstas no texto da Constituição e disciplinam a competência legislativa outorgada aos entes da Federação.

Com isso, poder-se-ia argumentar que tais preceitos deveriam ser interpretados de acordo com métodos específicos voltados à aplicação de normas de Direito Constitucional.

A discussão sobre a especificidade da interpretação constitucional é antiga na doutrina. Em favor da aplicação de métodos especiais à interpretação da Constituição são trazidos diversos argumentos, embora nem sempre formulados de maneira explícita ${ }^{133}$.

Um deles é o de que os textos constitucionais se diferenciam dos demais textos normativos em virtude do seu objeto, eis que disciplinam matéria constitucional. Ocorre que a própria definição do que seja "matéria constitucional" é controversa. Ademais, não só a Constituição disciplina matérias ditas constitucionais, como também o fazem outros diplomas legislativos. Basta pensar no caso das leis infraconstitucionais que versam sobre matéria eleitoral. Por fim, não fica claro por que razão a matéria disciplinada pela Constituição determinaria os métodos ou as técnicas a serem aplicados pelo intérprete do seu texto.

Um segundo argumento que poderia ser aduzido a favor da especificidade da interpretação constitucional é o de que os textos constitucionais seriam diferentes dos textos dos demais diplomas legislativos em virtude do seu conteúdo normativo, tendo em vista que eles não apenas expressam regras, mas instituem princípios e proclamam valores.

Contudo, o fato é que também os textos infraconstitucionais podem trazer princípios de grande relevância para o ordenamento jurídico, assim como valores. Sendo

133 Tais argumentos e as respectivas críticas são discutidos por GUASTINI, Riccardo. Teoria e Ideologia da Interpretação Constitucional. Revista Interesse Público, nº 40, 2006, pp. 231 e ss. 
assim, não se pode dizer que se trata de uma peculiaridade das normas constitucionais a ditar uma forma específica de interpretação.

Um terceiro argumento é o de que os textos constitucionais distinguem-se dos demais pelo seu objeto, eis que regulam relações políticas. Considerando que tais relações políticas, entre os órgãos do Estado e entre os cidadãos e o Estado, sofrem transformações com o decorrer do tempo, os métodos utilizados na interpretação constitucional deveriam ser capazes de adaptar o conteúdo dos textos normativos constitucionais a essas mudanças.

No entanto, como ressalta GUASTINI, assim como a "matéria constitucional" não pode ser encontrada apenas na Constituição, da mesma forma as relações políticas também podem ser disciplinadas por textos de leis infraconstitucionais. Ademais, nem toda norma constitucional disciplina relações políticas. Por fim, as transformações ocorrem em todo tipo de relação, não apenas nas relações políticas, como também nas relações econômicas, sociais etc. E tais transformações não necessariamente exigem uma interpretação dita "evolutiva", que adapte o texto da lei às novas relações. Com efeito, é possível argumentar que a adaptação da Constituição a uma nova realidade não deve ser obtida através da via interpretativa, mas sim por meio dos mecanismos previstos para a revisão constitucional.

O quarto argumento utilizado para justificar a especificidade da interpretação constitucional é o de que as Constituições foram feitas para durar por longos períodos de tempo e têm um procedimento rígido para sua emenda. Sendo assim, na linha do argumento anterior, deveriam receber interpretação que permita adaptá-las às mudanças da sociedade.

Porém, a longevidade da Constituição não é algo que se verifica em todos os países. Se é uma realidade para países como os Estados Unidos da América, não é para países como o Brasil, em que as Constituições costumam ter poucos anos ou décadas de duração. Inclusive, no Brasil, há inúmeras leis e diplomas infralegais que foram editados muito antes da Constituição de 1988. Ademais, a dificuldade de emenda da Constituição, embora seja uma realidade em nosso país, não se verifica em outros países que possuem uma Constituição flexível. Assim, tal argumento não pode ser utilizado para justificar a aplicação de um método específico para a sua interpretação. Outrossim, podem ser feitas as mesmas ressalvas feitas sobre o argumento anterior, no sentido de que a adaptação da Constituição às novas realidades deveria ser obtida pela via da revisão constitucional e não por métodos de interpretação. 
Diante disso, conclui-se que os textos constitucionais não possuem nenhuma peculiaridade que determine a aplicação de métodos específicos de interpretação ${ }^{134}$. Sendo assim, a princípio, os enunciados normativos que veiculam regras de imunidade tributária estão sujeitos aos mesmos métodos aplicados na interpretação dos demais textos normativos.

Se, de um lado, a natureza constitucional das regras da imunidade tributária não pode ser considerada suficiente para determinar a especificidade da sua interpretação, de outro lado, poder-se-ia alegar que o conteúdo de tais regras exigiria um tipo específico de aplicação.

Segundo alguns autores como PONTES DE MIRANDA, as imunidades tributárias deveriam ser interpretadas da mesma forma que as isenções tributárias, é dizer, seus preceitos deveriam receber interpretação estrita, não cabendo qualquer invocação de equidade ${ }^{135}$.

Entretanto, grande parte da doutrina distingue as imunidades das isenções no que diz respeito à sua interpretação. A título de exemplo, afirma AMílCAR DE ARAÚJo FALCÃo que a isenção, por ser regra excepcional, deveria ser interpretada estrita ou restritivamente, ao passo que a interpretação da imunidade deveria ser ampla, comportando todos os métodos de interpretação ${ }^{136}$. No mesmo sentido o magistério de GILBERTO DE UlHôA CANTO e BERnARdo DE RIBEIRO MoRAES, para quem os métodos adotados na interpretação desses preceitos seriam radicalmente diversos, tendo em vista que as imunidades seriam um instrumento de governo, ao passo que as isenções seriam um mero favor fiscal ${ }^{137}$.

Contudo, como salientado no capítulo anterior, as isenções, assim como as imunidades, não são favores fiscais ou privilégios concedidos pelo Estado. Ao contrário, são formas de desoneração tributária que devem possuir um fundamento claro, sob pena de decretação da sua inconstitucionalidade. Por esse motivo, não se justifica a adoção de critérios restritivos de interpretação quer no que toca às isenções quer no que tange às imunidades.

\footnotetext{
${ }^{134}$ Como aponta GUASTINI, alguns métodos podem ser mais recorrentes na interpretação constitucional não porque se trata de textos da Constituição, mas porque muitas vezes o que interpretamos são princípios e não regras. E os princípios possuem uma forma específica de aplicação aos casos concretos, eis que precisam ser concretizados e estão sujeitos às técnicas de ponderação e balanceamento (in Teoria e Ideologia da Interpretação Constitucional, p. 241). Considerando, no entanto, que aqui estamos diante de regras de imunidade, e não de princípios, tais particularidades não são aplicáveis à interpretação desses preceitos. ${ }^{135}$ MIRANDA, Pontes. Comentários à Constituição de 1946. Vol. II. 2. ed. São Paulo: Max Limonad, 1953, p. 168.

${ }^{136}$ FALCÃO, Amílcar de Araújo. Fato Gerador da Obrigação Tributária, p. 67.

${ }^{137}$ Afirma ULHÔA CANTO que a imunidade, ao contrário da isenção, não é um favor ou uma renúncia ao poder de tributar, mas uma limitação constitucional, um instrumento político de governo, uma restrição com a qual foi atribuída a competência tributária (in Temas de Direito Tributário, p. 195). No mesmo sentido o escólio de BERNARDO RIBEIRO DE MORAES, para quem a imunidade não é uma renúncia ou um favor, mas uma limitação constitucional, de modo que seus preceitos deveriam ser interpretados da mesma forma que as normas genéricas. Desse modo, conclui que "as normas referentes à imunidade tributária devem receber, da parte de quem as interpreta, um sentido ampliativo" (in Doutrina e Prática do Impôsto de Indústrias e Profissões, p. 656).
} 
Se é assim, haveria outro fator a determinar a interpretação desses preceitos?

Muitos autores brasileiros têm justificado a adoção de métodos ou de resultados específicos na interpretação das imunidades tributárias com base no argumento de que tais desonerações estão estreitamente vinculadas a valores prestigiados pela Constituição.

Assim, grande parte da doutrina brasileira afirma que as imunidades tributárias deveriam receber interpretação sempre "ampla" ou "generosa", tendo em vista que tais regras jurídicas são criadas com o objetivo de realizar importantes princípios constitucionais ${ }^{138}$.

Por sua vez, há quem afirme que a interpretação das imunidades não pode buscar ampliar ou restringir o alcance da norma constitucional, mas deve ser teleológica e sistemática, isto é, deve estar em conformidade com o contexto do sistema tributário brasileiro e especialmente com os princípios constitucionais para cuja proteção a imunidade foi criada.

Nesse sentido, afirma REgina HelEnA Costa ${ }^{139}$ :

[...] a interpretação da norma imunitória deve ser efetuada na exata medida; naquela necessária a fazer exsurgir o princípio ou valor nela albergado. Sendo assim, não se apresenta legítima a interpretação ampla e extensiva, conducente a abrigar, sob o manto da norma imunizante, mais do que aquilo que quer a Constituição, nem a chamada "interpretação literal", destinada a estreitar, indevidamente, os limites da exoneração tributária. Em ambos os casos o querer constitucional estaria vulnerado.

Na mesma linha, sustenta MARCO AuRÉlio GRECO que a interpretação das limitações ao poder de tributar "não pode resultar nem numa conclusão que implique em ela se tornar maior que o próprio poder que está sendo limitado (pois limitação não é negação do poder, mas restrição na sua amplitude e no seu exercício), nem pode dar à norma constitucional que a prevê um sentido tão restrito que iniba a proteção ao valor subjacente"140.

Por fim, há aqueles que afirmam que a interpretação dependerá da abrangência da imunidade em tela. Assim, leciona GERALDo AtAliBA que as imunidades ditas "gerais", contidas no art. 150, VI, têm como diretriz hermenêutica a liberdade religiosa, a liberdade de

\footnotetext{
${ }^{138}$ Vide nesse sentido: ROQUE CARRAZZA, para quem "a interpretação dos preceitos imunizantes há de ser o máximo possível generosa" (in A Imunidade Tributária das Empresas Estatais Delegatárias de Serviços Públicos, p. 25), EDUARDO BOTTALO, para quem "as normas imunizantes devem ser interpretadas com generosidade" (in Fundamentos do IPI, p. 109), ALIOMAR BALEEIRO, para quem as "cláusulas de imunidade exigem interpretação ampla" (in Limitações Constitucionais ao Poder de Tributar, p. 427), e HELY LOPES MEIRELLES, para quem, em matéria de imunidades, deve-se levar em conta uma "interpretação ampliativa" (in Direito Municipal Brasileiro, p. 195).

${ }^{139}$ COSTA, Regina Helena. Imunidades Tributárias, pp. 115-116.

140 GRECO, Marco Aurélio. Imunidade Tributária. In: MARTINS, Ives Gandra da Silva. Imunidades Tributárias, p. 711. A interpretação teleológica das imunidades tributárias também é defendida por ANDREI PITTEN VELLOSO, para quem tais preceitos devem ser interpretados de acordo com as suas finalidades, de modo a concretizar os valores constitucionais que inspiraram a sua criação (in Imunidade Tributária do Livro Digital: Fundamentos e Alcance. Revista de Estudos Tributários nº 83, 2012, pp. 23-23).
} 
informação etc., ao passo que as imunidades "tópicas" ou "especiais" têm a sua interpretação condicionada à teleologia própria de cada preceito. Em conclusão, sustenta que ${ }^{141}$ :

\begin{abstract}
4) a interpretação sistemática da Constituição indica, assim, que o grau de intensidade e a amplitude das imunidades genéricas, por ser bem mais significativo que o daquelas específicas - previstas em dispositivos esparsos, sem vinculação imediata com os princípios constitucionais básicos - é ampla e dirigida pela preocupação com a eficácia desses princípios;

5) As tópicas - em geral restritas a um só e determinado imposto e relativas a situações cujo âmbito material é circunscrito e limitado - postulam intensa preocupação finalística;

6) a interpretação destes preceitos exige pesquisa teleológica que permita determinar-lhe o conteúdo, sentido e alcance, para correta aplicação da norma imunizante em cada caso.
\end{abstract}

Essas diversas orientações também podem ser sentidas na jurisprudência do STF.

De fato, no julgamento do $\mathrm{RE} \mathrm{n}$ " 102.141/RJ, afirmou a Corte que "em se tratando de norma constitucional relativa às imunidades tributárias genéricas, admite-se a interpretação ampla, de modo a transparecerem os princípios e os postulados nela consagrados" $" 142$.

Por outro lado, no julgamento do RE $n^{\circ} 504.615$ AgR/SP, afirmou o Tribunal que a imunidade do art. 150, VI, "d", deveria ser interpretada restritivamente e que a expressão "papel destinado a sua impressão" poderia alcançar apenas os bens assimiláveis ao papel ${ }^{143}$.

Por fim, também pode-se encontrar em vários acórdãos do Supremo a afirmação de que as imunidades tributárias deveriam ser interpretadas sempre de forma teleológica ${ }^{144}$.

Pois bem. Conforme visto acima, não se justifica a afirmação apriorística de que as imunidades devam ser sempre interpretadas restritivamente, tendo em vista que tais normas não possuem qualquer particularidade que determine a utilização de tal critério de interpretação. Com efeito, embora limitem a competência tributária, não podem ser vistas como privilégios ou favores, concedidos a determinadas pessoas a custa dos cofres do Estado.

Por outro lado, afirmar que as imunidades devam receber interpretação sempre ampla ou generosa também não se sustenta, vez que, também aqui, não há qualquer fundamento que justifique tal conclusão. Isto é, embora seja admissível a interpretação extensiva dos preceitos, não há qualquer razão que determine tal extensão em todos os casos.

\footnotetext{
${ }^{141}$ ATALIBA, Geraldo. Venda de Minérios - Faturamento - PIS, pp. 306-308.

${ }^{142} \mathrm{RE} \mathrm{n}^{\mathrm{o}}$ 102.141/RJ, $2^{\mathrm{a}}$ Turma, Rel. Min. CARLOS MADEIRA, DJ 29.11.1985.

${ }^{143} \mathrm{RE} \mathrm{n}^{\circ}$ 504.615 AgR/SP, $1^{\mathrm{a}}$ Turma, Rel. Min. RICARDO LEWANDOWSKI, DJe 18.05.2011.

${ }^{144}$ Como se pode ver, não há no STF uma opção clara sobre a técnica ou o método de interpretação a ser adotado na aplicação das imunidades tributárias. Na realidade, não se trata de uma particularidade do Poder Judiciário brasileiro. ALIOMAR BALEEIRO já ressaltava a observação feita pelo justice Jackson acerca da aplicação da imunidade recíproca no direito norte-americano, no sentido de que "olhando retrospectivamente, é fácil ver-se que a linha entre o tributável e o imune tem sido traçada por um punho vacilante" (in Limitações Constitucionais ao Poder de Tributar, p. 390).
} 
Ademais, afirmar que as regras de imunidades devam receber interpretação sempre ampla ou extensiva não responde o problema da aplicação desses preceitos.

Isso porque as noções de "interpretação restritiva" e "interpretação extensiva" dizem respeito ao resultado da interpretação, e não ao seu método. Assim, são capazes apenas de dizer se o resultado obtido na interpretação de uma norma é legítimo (na medida em que abrange o âmbito nuclear dos termos ou alcança também sua franja marginal), mas não fornecem critérios ou métodos para que o intérprete possa realizar o trabalho interpretativo.

Daremos um exemplo para ilustrar esse ponto.

Prevê o art. 150, VI, “d”, da Constituição brasileira que são imunes à instituição de impostos os livros, jornais e periódicos e o papel destinado à sua impressão. Diante disso, pergunta-se: estariam abrangidos por esta imunidade apenas as atividades de comercialização de tais obras ou também as atividades de editoração e de impressão das mesmas e os serviços de publicidade prestados pelas empresas jornalísticas através da veiculação de anúncios?

Veja-se que a Constituição fala de forma bastante genérica em "livros, jornais e periódicos", sendo possível sustentar, de acordo com o uso linguístico geral desses termos, que a imunidade em testilha alcança apenas o produto acabado (sentido equivalente ao âmbito nuclear do termo) ou todas as atividades envolvidas na confecção da obra, como a editoração e a impressão, bem como os serviços de publicidade (elementos situados na franja marginal).

Tanto a interpretação que reconhece a imunidade tributária da impressão e da editoração, como aquela que reconhecesse a imunidade dos serviços de publicidade são igualmente interpretações "extensivas" e, a princípio, admissíveis no Direito brasileiro.

No entanto, o fato é que a jurisprudência do STF não adota o mesmo entendimento para um e outro caso. Com efeito, o Supremo Tribunal Federal tem reconhecido a imunidade dos serviços de publicidade prestados por empresas jornalísticas e, por outro lado, tem afastado a imunidade quanto às atividades de editoração e impressão de jornais ${ }^{145}$.

E isso porque, embora ambas sejam interpretações extensivas, os argumentos utilizados para defender um e outro caso de desoneração são, no mais das vezes, distintos.

Daí surge a necessidade de se analisar não apenas o resultado da interpretação, mas também o método utilizado no decorrer do processo interpretativo e os argumentos empregados na construção do sentido dos preceitos que consagram imunidades tributárias.

\footnotetext{
145 Tais decisões serão analisadas em maior detalhe no Capítulo 6 deste trabalho.
} 
E aqui ganha importância a relação entre as imunidades e os princípios constitucionais, não para definir o resultado da sua interpretação, mas sim para determinar quais argumentos adquirem maior preponderância na interpretação desses dispositivos.

Já vimos nos capítulos anteriores que, no Direito brasileiro, têm precedência os argumentos que sejam imanentes ao ordenamento jurídico, tais como os argumentos linguísticos e os sistemáticos. Especialmente quanto ao sistemático, é importante prestigiar o sentido que seja mais consentâneo com o princípio constitucional subjacente ao dispositivo interpretado. Em seguida, podem ser considerados os argumentos históricos, em importância menor os argumentos genéticos e, por fim, os argumentos de índole meramente prática.

No entanto, também já foi salientado nesse trabalho que tal ordem hierárquica não é estática, mas depende das circunstâncias do caso e do dispositivo sujeito à análise.

No caso das imunidades tributárias previstas no art. 150, VI, da Constituição de 1988, verifica-se que a redação utilizada pelo legislador foi bastante genérica, ao contrário de outros dispositivos constitucionais, que disciplinam em maiores detalhes a matéria tributária.

Assim, a Constituição fala da imunidade dos "livros", dos "templos de qualquer culto", das "instituições de educação e de assistência social”, termos estes bastante amplos e que podem abranger inúmeros significados. Diante disso, a utilização de argumentos linguísticos, embora possa fornecer alguns limites à aplicação dessas imunidades (na medida em que a interpretação desses preceitos está limitada ao sentido literal possível do seu texto), muitas vezes não será suficiente para determinar a sua aplicação aos casos concretos.

Assim ganham relevo os argumentos sistemáticos, que põem em destaque a relação entre as imunidades e outras normas do sistema brasileiro, em especial aquelas que consagram princípios constitucionais e que com elas estão intimamente entrelaçados.

Nos argumentos sistemáticos, inclui-se o estudo da função da regra no sistema jurídico, é dizer, da sua teleologia relativamente ao ordenamento como um todo. Nesse tipo de argumentação, portanto, é possível analisar a função exercida pelas imunidades tributárias na realização dos princípios constitucionais a elas subjacentes. Da mesma forma, tais argumentos permitem verificar os limites fornecidos por outros princípios à aplicação das regras de desoneração tributária, tais como o princípio da livre concorrência e o princípio da igualdade.

É o que também conclui HuMBERTo Ávila, para quem as imunidades são adequadamente compreendidas quando interpretadas de acordo com os princípios que lhe são subjacentes ${ }^{146}$. Ensina o autor que os princípios, assim como as regras, também exercem

146 ÁVILA, Humberto. Sistema Constitucional Tributário, pp. 99 e ss. 
funções eficaciais. Uma delas é a função integrativa, pela qual os princípios permitem agregar elementos à interpretação que não foram previstos pelas regras ou pelos subprincípios. Também exercem função definitória, delimitando o conteúdo de um princípio superior, que é mais amplo. Exercem a função interpretativa, na medida em que auxiliam na interpretação das regras já previstas no ordenamento, restringindo ou ampliando seu significado. Tem também uma função bloqueadora, afastando determinados elementos que são incompatíveis com o estado de coisas que buscam promover. Exercem função rearticuladora, permitindo a interação entre diversos elementos que compõem esse estado de coisas a ser buscado. Exercem uma função seletiva, selecionando os fatos pertinentes (exame de pertinência) e os pontos de vista adequados para interpretar os fatos (exame de valoração) e uma função valorativa, privilegiando certos pontos de vista que protejam os bens jurídicos. Têm uma função argumentativa, já que toda restrição a um princípio promovida pelo Estado deve ser devidamente justificada, uma função de defesa, vedando intervenções do Estado, e, por fim, protetora, porque determinam a adoção de medidas para proteção dos direitos de liberdade.

$\mathrm{Na}$ interpretação das imunidades tais funções dos princípios devem ser levadas em consideração, na medida em que os princípios colaboram para a construção do sentido desses preceitos, conferindo também limites para a sua aplicação aos casos concretos, já que o reconhecimento da desoneração não pode levar a uma violação grave de outras garantias previstas pelo Texto Constitucional. Ademais, os princípios determinam o estado de coisas que deve ser buscado, traçando assim os objetivos que devem ser perseguidos pelo Estado e que devem ser levados em conta quando da interpretação das imunidades tributárias.

Sendo assim, é necessário analisar a relação entre as imunidades tributárias e os princípios e tal análise não pode ser feita apenas no plano conceitual, mas deve também ser realizada no plano da eficácia. Analisando-se a eficácia de tais normas, pode-se verificar, por exemplo, que a imunidade das entidades de educação e assistência social, quando aplicada a atividades comerciais, pode gerar restrições à livre concorrência, dado que essas entidades poderão praticar preços mais baixos no mercado em virtude da desoneração tributária ${ }^{147}$.

De fato, a interpretação que ignora os efeitos trazidos pelo reconhecimento da imunidade é míope, já que desconsidera uma das principais facetas do Direito, que é a sua aplicação concreta e as transformações que tal aplicação podem trazer à sociedade. Se as imunidades colaboram para a realização de determinadas finalidades, resta evidente que sua

${ }^{147}$ No mesmo sentido: ÁVILA, Humberto. Sistema Constitucional Tributário, p. 139. 
interpretação deve analisar se esses objetivos estão sendo concretamente realizados e se tal efetivação tem impactado negativamente a realização de outros valores prezados pela Carta.

Como veremos nos próximos capítulos, a necessidade de uma análise da eficácia das regras de imunidade tributária também tem sido sentida pela nossa jurisprudência, que tem buscado cada mais vez mais analisar os efeitos concretos do reconhecimento da imunidade em cada caso, tendo em vista as características da pessoa beneficiada pela desoneração tributária, bem como as peculiaridades do mercado em que tal pessoa opera.

Tendo em mente as considerações expostas no presente capítulo, passaremos a analisar cada uma das imunidades tributárias previstas no art. 150, VI, da Constituição brasileira de 1988, examinando as principais questões hoje debatidas pela doutrina e pela jurisprudência acerca da interpretação desses preceitos e da sua aplicação aos casos concretos. 
4. A Imunidade Recíproca. 


\subsection{Histórico da Imunidade.}

A imunidade recíproca tem suas origens na jurisprudência norte-americana, que exerceu forte influência não só na inserção desse preceito nos textos das Constituições brasileiras, como também na interpretação que lhe deu o Supremo Tribunal Federal.

A Constituição norte-americana é bastante sintética e não previu expressamente a imunidade das pessoas políticas de Direito Público no que tange à tributação. De acordo com BALEEIRO, ela surgiu assim como uma construção jurisprudencial e como consequência indireta da teoria dos poderes implícitos, a fim de proteger a União em face dos Estados ${ }^{148}$.

Tal construção teve início no caso McCulloch vs. Maryland, em virtude da tentativa do Estado de Maryland de tributar uma filial do banco nacional recém criado. $\mathrm{Na}$ ocasião, a Suprema Corte norte-americana reconheceu a imunidade dos instrumentos do governo federal em face da tributação dos Estados. A argumentação então utilizada pelo Chief Justice Marshall foi assim sintetizada por LÉDA BOECHAT RoDRIGUES ${ }^{149}$ :

Segundo o consenso geral, e êle não o negava, era o governo americano "um govêrno de poderes enumerados"; mas, apesar de limitada em seus poderes, "era a União suprema na sua esfera de ação. Isso parecia resultar necessariamente de sua natureza. É o governo de todos; seus poderes são delegados por todos; representa todos e age por todos". Entre os poderes enumerados, continuava, não se encontrava "o de estabelecer um banco ou criar uma companhia (corporation). Mas não há, na Constituição, nenhuma frase que, a exemplo dos Artigos de Confederação, exclua os poderes implícitos ou incidentes ou exija seja todo o concedido expressa e municiosamente descrito". (...)

Apesar de não constar entre os poderes enumerados do govêrno, dizia MARSHALL, a palavra "banco" ou "incorporação", entre êles se encontravam "os grandes poderes de instituir e cobrar impostos; de tomar dinheiro emprestado; de regular o comércio; de declarar e conduzir guerras; e de levantar e manter exércitos e armadas. (...) Jamais se poderá pretender que êsses vastos poderes excluem outros de importância inferior, somente porque são inferiores". Um govêrno a que se haviam confiado tão amplos poderes devia ter, também, amplos meios para a execução dos mesmos. (...) Intimamente entrelaçado a tôda a Constituição, havia um grande princípio, do qual não era possível abstrair sem reduzi-la a pedaços: "A Constituição e as leis feitas em conseqüência delas são supremas; controlam as Constituições e as leis dos respectivos Estados e não podem ser por estas controladas. Deste princípio, quase axiomático, decorrem, como corolários, outras proposições: .... 1) o poder de criar implica o de preservar; 2) o poder de destruir entregue a mãos diferentes é hostil e incompatível com os poderes de criar e preservar; 3) quando tal ocorre, a autoridade suprema deve controlar e não ceder àquela sôbre a qual possui supremacia".

Depois de haver estudado acuradamente o assunto em debate, prosseguia MARSHAL, chegara a Corte à convicção de não possuírem "os Estados poder, mediante a decretação de impostos ou de outra forma, para retardar, impedir, obstar,

148 BALEEIRO, Aliomar. Limitações Constitucionais ao Poder de Tributar, pp. 382-384.

${ }^{149}$ RODRIGUES, Léda Boechat. A Corte Suprema e o Direito Constitucional Americano. $2^{\text {a }}$ ed. Rio de Janeiro: Civilização Brasileira, 1992, pp. 42-44. 
ou, de qualquer modo, controlar a execução das leis constitucionais promulgadas pelo Congresso, tendo em vista os poderes outorgados ao governo geral. Esta, pensamos, é a conseqüência inevitável da supremacia declarada pela Constituição".

Argumentou também MARSHALL que a União não poderia estar sujeita a tributos que haviam sido votados apenas pelos eleitores de determinado Estado. Vale conferir ${ }^{150}$ :

\begin{abstract}
O povo de um Estado, portanto, concede ao seu governo o direito de o tributar e também tributar a sua propriedade, e considerando que as exigências do Governo não podem ser limitadas, o povo não prescreve limites ao exercício desse direito, confiado em que o interesse do legislador e a influência dos eleitores nos seus representantes o preservam de qualquer abuso. Porém, os meios empregados pela União não possuem a mesma garantia, nem tem o Estado o direito de tributá-los com base na mesma teoria. Aqueles meios não são outorgados pelo povo de um Estado particular, nem conferidos pelos eleitores da legislatura, que se arroga o direito de tributá-los, mas pelo povo de todos os Estados. Eles são outorgados por todos, para o benefício de todos - e, de acordo com a teoria, devem estar sujeitos apenas ao Governo que pertence a todos.
\end{abstract}

Com base nesse entendimento, reconheceu a Suprema Corte norte-americana que o Estado de Maryland não poderia tributar a filial do banco nacional então criado, tendo em vista que tal filial corresponderia a um instrumento de ação do governo federal.

Frise-se que, naquela época, a jurisprudência entendia a imunidade aplicável apenas à União, isto é, não havia reciprocidade para afastar a tributação dos Estados.

O argumento seguia o raciocínio de MARSHALl exposto acima. É dizer, a União era imune, porque os cidadãos americanos não poderiam ser submetidos a impostos que haviam sido votados por apenas uma parcela da população, de determinado Estado, e destinados a satisfazer os interesses locais. Já a União poderia tributar os Estados, eis que os impostos federais haviam sido votados por representantes de todos os Estados no âmbito do Congresso Nacional, não se podendo falar em falta de consentimento em tal caso ${ }^{151}$.

Ademais, como salienta BALEEIRO, naquela época, a imunidade da União era interpretada de forma ampla, abrangendo todas as instrumentalidades do governo federal, incluindo entidades, bens, títulos públicos e também vencimentos de funcionários federais ${ }^{152}$.

Porém, com o posterior fortalecimento da União, a Suprema Corte modificou o seu entendimento, de modo a proteger também os Estados por meio da imunidade recíproca.

Assim, foi reconhecida a imunidade tributária dos títulos públicos e dos vencimentos de funcionários estaduais em relação ao fisco federal ${ }^{153}$. No entanto, no que

${ }^{150}$ MARSHALL, John. The Constitutional Decisions of John Marshall. Vol. I. Editado por Joseph P. Cotton Jr. Nova Iorque: G.P. Putnam's Sons, 1905, p. 336 (tradução livre).

${ }^{151}$ BALEEIRO, Aliomar. Limitações Constitucionais ao Poder de Tributar, p. 384.

152 Ibidem, 384. 
tange à imunidade dos Estados, a Suprema Corte americana sempre reconheceu limitações ao seu alcance. BALEEIRO cita o exemplo do imposto federal que incidia sobre bilhetes de um banco estadual para fins de controle da circulação monetária, em relação ao qual não se aplicou a imunidade tributária. A Corte também distinguia as hipóteses em que o Estado atuava no exercício de poderes governamentais e naqueles em que ele atuava como um empreendedor privado (private business ou proprietary character). A imunidade aplicava-se apenas ao primeiro caso, mas não ao segundo, em virtude da natureza de tais atividades.

Assim, a Corte reconheceu a possibilidade de incidência de impostos sobre jogos de futebol, que eram realizados em um estádio construído pelo Estado da Geórgia com o fim de manter sua universidade e outras instituições de ensino. Naquele caso, o Estado alegava que as rendas obtidas com os jogos eram voltadas a custear atividades públicas (vale dizer, a educação) e, mesmo em face de tal argumento, a Suprema Corte não reconheceu a imunidade. Por outro lado, no que tange à União, a Corte reconhecia que a imunidade recíproca aplicavase não apenas às atividades de governo, como também às explorações comerciais, sendo exemplo disso a vedação à tributação da comercialização de energia elétrica pela TVA ${ }^{154}$.

Após a Primeira Guerra Mundial, a jurisprudência da Suprema Corte passou a seguir novos rumos, estabelecendo maiores limitações à aplicação da imunidade recíproca. Assim, passou-se a reconhecer a possibilidade de tributação dos salários de funcionários públicos federais, desde que o imposto não possuísse caráter discriminatório. Esse entendimento deu origem ao Public Salary Act de 1939, o qual autorizava a instituição de impostos federais sobre vencimentos de funcionários estaduais e locais, desde que o tributo não estabelecesse qualquer discriminação em virtude da fonte dos rendimentos ${ }^{155}$.

Pois bem. Inspirada na jurisprudência norte-americana, a imunidade recíproca foi incluída pela primeira vez no ordenamento brasileiro no art. 10 da Constituição de 1891, tendo clara influência de RUI BARBosA. Previa o referido dispositivo que era vedado "aos Estados tributar bens e rendas federais ou serviços a cargo da União, e reciprocamente".

Como se pode ver, proibia-se a instituição de todo e qualquer tributo, e não só dos impostos. Ademais, naquele tempo, a imunidade tributária vedava apenas a tributação dos bens e das rendas da União e dos Estados, não sendo aplicável aos Municípios. Tal dispositivo estava alinhado com a estrutura federativa daquele Texto Constitucional, que atribuía competência para instituir tributos apenas à União (art. $7^{\circ}$ ) e aos Estados $\left(\operatorname{art.} 9^{\circ}\right)$.

${ }^{153}$ Ibidem, pp. 384-385.
${ }^{154}$ Ibidem, pp. 385-386.
${ }^{155}$ Ibidem, pp. 387-388. 
Inicialmente, a jurisprudência brasileira, seguindo os passos da Suprema Corte americana, atribui interpretação ampla à imunidade. A jurisprudência, por outro lado, não era clara quanto à possibilidade de um Estado tributar bens e serviços de outro Estado ${ }^{156}$.

A Constituição de 1934 manteve a imunidade recíproca e a estendeu também aos Municípios. Essa extensão conformava-se ao texto da nova Carta, que atribuiu competência aos Municípios para instituir certos tributos, os quais incluíam o imposto de licenças, os impostos predial e territorial urbanos, o imposto sobre diversões públicas, o imposto cedular sobre a renda de imóveis rurais e as taxas sobre serviços municipais (art. 13, $\S 2^{\circ}$ ).

A imunidade também foi estendida às concessões de serviços públicos.

Em resumo, previa a Constituição brasileira que era vedado à União, aos Estados, ao Distrito Federal e aos Municípios "tributar bens, rendas e serviços uns dos outros, estendendo-se a mesma proibição às concessões de serviços públicos, quanto aos próprios serviços concedidos e ao respectivo aparelhamento instalado e utilizado exclusivamente para o objeto da concessão", conforme redação do seu art. 17, X.

Cumpre salientar que, nessa época, foi editado o Decreto-lei $\mathrm{n}^{\circ} 1.564 / 1939$, em resposta à jurisprudência então firmada pelo STF, que havia declarado inconstitucional a incidência do imposto de renda sobre vencimentos de funcionários estaduais e municipais. Referido decreto tornou sem efeito as decisões do Supremo e confirmou as leis da União que sujeitaram ao imposto de renda tais vencimentos. Segundo AlIOMAR BALEEIRO, a partir de então, passou-se a admitir sem resistência referida tributação, adotando-se o critério do Public Salary Act americano, de modo que o imposto não poderia ter caráter discriminatório ${ }^{157}$.

A Constituição de 1937 manteve a imunidade recíproca, ressaltando que os serviços públicos concedidos não gozavam de imunidade e que eventual isenção poderia ser outorgada no interesse comum por lei especial. A desoneração também foi prevista pela Carta de 1946, a qual, no entanto, estabeleceu em seu art. 31, V, que os entes federados não poderiam lançar impostos (e não mais tributos) sobre bens, rendas e serviços dos demais.

Com a edição da Emenda Constitucional $n^{\circ}$ 18/1965, a imunidade recíproca foi estendida também às autarquias, no que diz respeito ao patrimônio, à renda e aos serviços vinculados às suas finalidades essenciais, ou delas decorrentes (art. $2^{\circ}, \S 1^{\circ}$ ). A Carta de 1967 reiterou a imunidade, e a Constituição de 1988 estabeleceu que o benefício seria extensível também às fundações instituídas e mantidas pelo Poder Público, mas que não poderia ser aplicado ao patrimônio, à renda e aos serviços relacionados com a exploração de atividades

\footnotetext{
${ }^{156}$ Ibidem, pp. 405-407.

${ }^{157}$ Ibidem, p. 408.
} 
econômicas regidas pelas normas aplicáveis a empreendimentos privados ou em que houvesse contraprestação ou pagamento de preços ou tarifas pelo usuário (art. $150, \S \S 2^{\circ}$ e $3^{\circ}$, da $C F$ ). 


\subsection{Função Exercida pela Imunidade.}

A imunidade recíproca relaciona-se intimamente com importantes princípios constitucionais. Em primeiro lugar, ela visa garantir o pacto federativo, impedindo que a tributação seja utilizada como forma de sujeitar os demais entes federados. A imunidade recíproca assegura, dessa forma, a igualdade das pessoas políticas de Direito Público.

O pacto federativo é de extrema relevância para o regime democrático, eis que evita a concentração do poder em apenas uma esfera de governo e também contribui para a preservação das diferenças sociais e culturais existentes entre as diversas regiões do país ${ }^{158}$.

Assim, com o objetivo de garantir a Federação, a Constituição prevê de maneira detalhada a competência atribuída à União, aos Estados, ao Distrito Federal e aos Municípios, evitando o exercício de poderes por um ente federado sobre matérias atribuídas a outros entes.

No entanto, a discriminação de competências não basta para preservar a Federação. Como aponta FRANCISCO CAMPOS, é necessário que se proíba qualquer interferência por parte dos governos nas atividades legítimas dos outros, quer diretamente, quer por vias indiretas através da criação de "óbices, embaraços, tropeços, ou empecilhos ao exercício das suas funções constitucionais". Sobretudo, é necessário impedir que os entes federados possam "onerar, de qualquer maneira, diminuir ou destruir a eficácia dos meios ou instrumentos necessários ou adequados à ação dos seus órgãos na órbita constitucional da sua competência" ${ }^{159}$. Ora, uma das principais formas indiretas de destruir ou diminuir a eficácia dos meios de ação de outros governos é justamente a via tributária, como acrescenta o autor:

\footnotetext{
Nenhum campo, porém, como o tributário, mais propício ao conflito de poderes, mais fértil em oportunidades para a concorrência prejudicial entre os governos, seja conscientemente orientada no mau sentido, e, portanto, desleal ou ilícita, seja por motivo da fluidez ou da indeterminação da matéria tributária, que, sendo a mesma e uma só, por mais precisamente que se recortem no mapa constitucional os contornos da sua divisão, comportará sempre a espécie esquiva e fugidia dos casos marginais, cuja ambiguidade dá lugar a que sobre eles se concentrem os fogos cruzados dos fiscos concorrentes.
}

Logo, é necessário evitar que a tributação se transforme em um instrumento para subjugar, oprimir, sujeitar outros entes federados, preservando assim o equilíbrio federativo.

\footnotetext{
${ }^{158}$ DERZI, Misabel. Limitações Constitucionais ao Poder de Tributar, nota de atualização, p. 400.

${ }^{159}$ CAMPOS, Francisco. Direito Constitucional. Rio de Janeiro: Freitas Bastos, 1956, pp. 19-20.
} 
Mas não é só. A imunidade recíproca não se volta apenas à garantia da Federação. Ela é também uma decorrência do princípio da capacidade contributiva, eis que os entes federados e suas instrumentalidades não possuem capacidade para arcar com o pagamento de impostos, já que todos os seus recursos estão voltados ao custeamento dos gastos públicos ${ }^{160}$.

Bem por isso, prevalece na doutrina brasileira o entendimento de que a imunidade recíproca não necessitaria sequer de consagração expressa no Texto Constitucional ${ }^{161}$, já que constitui uma decorrência necessária dos princípios federativo e da capacidade contributiva.

160 SCHOUERI, Luís Eduardo. Direito Tributário, p. 379; DERZI, Misabel. Limitações Constitucionais ao Poder de Tributar, nota de atualização, p. 403.

161 DERZI, Misabel. Limitações Constitucionais ao Poder de Tributar, nota de atualização, p. 404; CARRAZZA, Roque Antônio. A Imunidade Tributária das Empresas Estatais Delegatárias de Serviços Públicos, pp. 28-29, LACOMBE, Américo Lourenço Masset. Imunidade Tributária Recíproca. In: Estudos Jurídicos em Homenagem a Vicente Ráo. São Paulo: Resenha Universitária, 1976, pp. 214-215; CARVALHO, Paulo de Barros. Curso de Direito Tributário, p. 206; ÁVILA, Humberto. Sistema Constitucional Tributário, p. 279; ATALIBA, Geraldo. Sistema Constitucional Tributário Brasileiro, p. 54; CAMPOS, Francisco. Direito Constitucional, pp. 18-20. 


\subsection{Impostos Abrangidos pela Imunidade.}

De acordo com o art. 150, VI, “a”, da Constituição Federal de 1988, é vedado aos entes federados instituir impostos sobre o patrimônio, a renda e os serviços, uns dos outros.

Diante da redação adotada pela Constituição, surgiu na doutrina uma controvérsia sobre os tributos abrangidos pela imunidade recíproca, eis que o Código Tribunal Nacional traz uma classificação dos impostos, incluindo na categoria "Impostos sobre o Patrimônio e a Renda" somente o Imposto sobre a Propriedade Territorial Rural, o Imposto sobre a Propriedade Predial e Territorial Urbana, o Imposto sobre a Transmissão de Bens Imóveis e de Direitos a eles Relativos e o Imposto sobre a Renda e Proventos de Qualquer Natureza.

Inicialmente, alguns autores como SACHA CALMON NAVARRO Cô̂LHO, sustentaram que a redação adotada pela Constituição, aliada à classificação trazida pelo CTN, permitiria concluir que apenas os seguintes impostos estariam abrangidos pela imunidade recíproca: (i) o imposto sobre a renda e os proventos de qualquer natureza; (ii) o imposto sobre a transmissão de bens imóveis e de direitos e a eles relativos, exceto os de garantia entre vivos e mortos; (iii) o imposto sobre a propriedade territorial e predial urbana; (iv) o imposto sobre a propriedade territorial rural; e (iv) o imposto sobre a propriedade de veículos automotivos; (v) o imposto sobre serviços de qualquer natureza; e (vi) o imposto sobre serviços de comunicação e de transporte interestadual e intermunicipal. Desse modo, a desoneração em tela não poderia abranger, a título de exemplo, os impostos sobre movimentações financeiras e sobre as operações de circulação de mercadorias ${ }^{162}$.

Em contraposição a esse entendimento, autores como ALIOMAR BALEEIRO argumentavam que os termos "renda", "patrimônio" e "serviços" haviam sido empregados pelo constituinte de forma ampla, abrangendo todos os impostos do sistema tributário ${ }^{163}$.

E esse foi o entendimento que veio a prevalecer na doutrina. Afirmou-se que a interpretação da Constituição não poderia ser feita com base em uma classificação infraconstitucional e que o objetivo do constituinte teria sido, na realidade, incluir todos os impostos na esfera da imunidade. Logo, a imunidade recíproca não deveria se restringir aos

\footnotetext{
${ }^{162}$ DERZI, Misabel e COÊLHO, Sacha Calmon Navarro. A Imunidade Intergovernamental Recíproca e sua Extensão às Autarquias Federais, p. 105. Frise-se que, posteriormente, esse autor mudou seu posicionamento e alinhou-se à posição majoritária para reconhecer que a imunidade recíproca abrangeria todos os impostos, independentemente da sua hipótese de incidência, na linha do posicionamento também consolidado pelo STF. Nesse sentido COÊLHO, Sacha Calmon Navarro. Comentários à Constituição de 1988, pp. 314 e ss.

${ }^{163}$ BALEEIRO, Aliomar. Limitações Constitucionais ao Poder de Tributar, pp. 461 e ss.
} 
tributos mencionados acima, mas abranger todos os impostos, independentemente da sua hipótese de incidência ${ }^{164}$.

Essa foi também a conclusão do $\mathrm{STF}^{165}$. O Tribunal também declarou inconstitucional a incidência do Imposto Provisório sobre a Movimentação ou a Transmissão de Valores e de Créditos e Direitos de Natureza Financeira (IPMF) sobre as movimentações financeiras realizadas pelos entes federados, então prevista pela Emenda Constitucional $n^{\circ}$ 3/1993 ${ }^{166}$, e afastou a incidência do Imposto sobre Operações de Crédito, Câmbio e Seguros, ou relativas a Títulos e Valores Mobiliários (IOF) sobre os ganhos resultantes de operações financeiras realizadas pela União, os Estados, o Distrito Federal e os Municípios ${ }^{167}$.

O STF também reconheceu que a imunidade recíproca alcançava o IPI e o ICMS.

No entanto, controvérsias surgiram quanto às operações abrangidas pelo benefício, eis que nesses tributos há translação do ônus ao adquirente das mercadorias.

Quanto ao ICMS-Importação, entendeu o Tribunal que o ente público que realizasse a importação de mercadorias poderia invocar a imunidade tributária, ainda que fosse o adquirente dos bens, vez que nesses casos ele é o contribuinte de direito da exação ${ }^{168}$.

Por outro lado, quanto às aquisições realizadas no mercado interno, a jurisprudência oscilou nas últimas décadas. Inicialmente, o STF, sob a clara influência de ALIOMAR BALEEIRO, reconheceu que as entidades imunes que adquirissem mercadorias no mercado interno e que, portanto, fossem os contribuintes de fato do ICMS e do IPI, poderiam invocar a aplicação da imunidade recíproca para afastar a incidência desses tributos ${ }^{169}$.

A justificativa era a de que o encargo do tributo só poderia desfalcar o patrimônio do ente público quando ele fosse o contribuinte de fato da exação, isto é, quando adquirisse a mercadoria. Por sua vez, quando o ente imune comercializasse bens para terceiros e

\footnotetext{
${ }^{164}$ Veja-se nesse sentido, dentre outros, o entendimento dos seguintes autores: CARRAZZA, Roque Antônio. A Imunidade Tributária das Empresas Estatais Delegatárias de Serviços Públicos, p. 29; DERZI, Misabel. Limitações Constitucionais ao Poder de Tributar, p. 471; SCHOUERI, Luís Eduardo. Direito Tributário, p. 380. ${ }^{165}$ Vide os seguintes precedentes do STF acerca da interpretação da expressão "patrimônio, bens e serviços": RE $\mathrm{n}^{\mathrm{o}}$ 203.755/ES, $2^{\mathrm{a}}$ Turma, Rel. Min. CARLOS VELLOSO, DJ 08.11.1996; AI no 481.586 AgR/MG, $2^{\mathrm{a}}$ Turma, Rel. Min. CARLOS VELLOSO, DJ 24.02.2006; RE n ${ }^{\circ} 540.725$ AgR/SC, $2^{\mathrm{a}}$ Turma, Rel. Min. EROS GRAU, DJe 12.03.2009; RE no 87.913/SP, $1^{\text {a }}$ Turma, Rel. Min. RODRIGUES ALCKMIN, DJ 29.12.1977; RE ${ }^{\circ}$

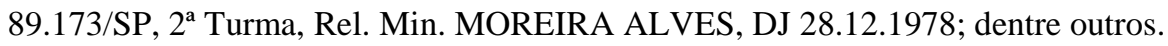

166 ADI n 939/DF, Pleno, Rel. Min. SYDNEY SANCHES, DJ 18.03.1994.

${ }^{167} \mathrm{AI} \mathrm{n}^{\circ}$ 175.133 AgR/PR, 2 ${ }^{\mathrm{a}}$ Turma, Rel. Min. MARCO AURÉLIO, DJ 26.04.1996; e RE nº 192.888/DF, $2^{\mathrm{a}}$ Turma, Rel. Min. CARLOS VELLOSO, DJ 11.10.1996.

${ }^{168}$ Vide por exemplo: AI n ${ }^{\circ}$ 518.405 AgR/RS, $2^{\text {a }}$ Turma, Rel. Min. JOAQUIM BARBOSA, DJe 29.04.2010.

${ }_{169}$ Vide nesse sentido os seguintes julgados: RE $n^{\circ}$ 67.628/SP, $1^{\text {a }}$ Turma, Rel. Min. ALIOMAR BALEEIRO, DJ 14.11.1969; RE $n^{\circ}$ 67.547/SP, $1^{\text {a }}$ Turma, Rel. Min. ALIOMAR BALEEIRO, DJ 05.12.1969; RE $n^{\circ}$ 68.913/SP, $1^{\text {a }}$ Turma, Rel. Min. ALIOMAR BALEEIRO, DJ 24.04.1970; e RE nº 69.506/SP, $1^{\text {a }}$ Turma, Rel. Min. ALIOMAR BALEEIRO, DJ 03.11.1970.
} 
transferisse o ônus tributário, a imunidade não pode ser reconhecida, eis que, nessas hipóteses, o encargo do tributo não recairia sobre os meios de ação da pessoa de Direito Público.

No entanto, esse entendimento foi superado no julgamento dos RE $n^{\circ} 68.215$ $\mathrm{EDv} / \mathrm{SP}^{170}, \mathrm{RE} \mathrm{n}^{\mathrm{o}}$ 68.097 EDv/SP ${ }^{171}$ e $\mathrm{RE} \mathrm{n}^{\circ}$ 67.625 EDv/SP ${ }^{172}$, ocorrido em 09.09.1970.

Naquela ocasião, argumentaram os Ministros do STF que a realidade econômica não poderia se opor à forma jurídica para afastar a tributação. Ademais, afirmaram que a relação tributária estabelecer-se-ia entre o contribuinte de direito e o ente federado, sendo o contribuinte de fato estranho a essa relação. Diante disso, concluiu o Supremo que, nos casos em que o ente público é o adquirente da mercadoria, a imunidade não poderia ser aplicada, por se tratar de mero contribuinte de fato. Por outro lado, quando o ente fosse o vendedor, a imunidade poderia ser reconhecida, ainda que houvesse transferência do ônus tributário ${ }^{173}{ }^{174}$.

Esta posição prevalece na jurisprudência do STF até os dias atuais, sendo o mesmo entendimento aplicado às imunidades previstas nas alíneas "b" e "c" do art. 150, VI.

Entretanto, vale ressaltar que atualmente aguarda julgamento naquele Tribunal o RE n 608.872 RG/MG, submetido à sistemática da repercussão geral, no qual se discute a aplicação da imunidade tributária às aquisições de bens no mercado interno (tais como medicamentos, máquinas e equipamentos) realizadas por instituições de assistência social, tendo em vista que, nessas hipóteses, elas são apenas os contribuintes de fato do ICMS.

\footnotetext{
${ }^{170}$ RE nº 68.215 EDv/SP, Pleno, Rel. p/ acórdão Min. THOMPSON FLORES, DJ 16.04.1971.

${ }^{171} \mathrm{RE} \mathrm{n}^{\circ}$ 68.097 EDv/SP, Pleno, Rel. Min. BARROS MONTEIRO, DJ 12.03.1971.

${ }^{172} \mathrm{RE} \mathrm{n}^{\circ}$ 67.625 EDv/SP, Pleno, Rel. Min. THOMPSON FLORES, DJ 20.11.1970.

${ }^{173} \mathrm{O}$ mesmo entendimento veio a prevalecer nos julgados posteriores, tais como: $\mathrm{RE} \mathrm{n}^{\mathrm{o}}$ 68.741/SP, $2^{\mathrm{a}}$ Turma, Rel. Min. BILAC PINTO, DJ 23.10.1970; RE nº 69.483 EDv/SP, Pleno, Rel. Min. BILAC PINTO, DJ 27.11.1970; RE no 68.144 EDv/SP, Pleno, Rel. Min. ADALÍCIO NOGUEIRA, DJ 27.11.1970; e RE $\mathrm{n}^{\circ}$ 70.172/SP, $2^{\text {a }}$ Turma, Rel. Min. ANTONIO NEDER, DJ 20.11.1972.

${ }^{174}$ Há autores, como MISABEL DERZI, que criticam a jurisprudência do STF. Afirma DERZI que, no caso do ICMS e do IPI, a translação não é um fenômeno meramente econômico, mas jurídico, eis que a transferência do ônus é pressuposta pela própria Constituição quando estabelece o regime da não-cumulatividade (in Limitações Constitucionais ao Poder de Tributar, nota de atualização, pp. 483 e ss.). Ademais, o art. 166 do CTN também consagra o critério da translação, ao prever que a restituição de tributos que comportem transferência do respectivo encargo financeiro somente poderá ser feita àquele que comprovou ter assumido o referido encargo. Assim, nas palavras de BALEEIRO, o nosso direito não ignoraria o contribuinte de fato, de modo que ignorar a repercussão contrariaria os fins da Constituição e das leis infraconstitucionais (in Limitações Constitucionais ao Poder de Tributar, p. 465). Em sentido contrário vale mencionar a posição de autores como PAULO DE BARROS CARVALHO (in Curso de direito tributário, p. 207) e HUGO DE BRITO MACHADO (Curso de Direito Tributário, p. 290), para quem o adquirente das mercadorias, por ser o contribuinte de fato do IPI e do ICMS, é estranho à relação jurídica e não pode invocar a imunidade tributária.
} 


\subsection{Pessoas Abrangidas pela Imunidade.}

Outro ponto relevante na interpretação da imunidade recíproca diz respeito às pessoas beneficiadas pela desoneração. É dizer, se apenas os entes federados poderiam fazer jus à imunidade ou se esta poderia ser invocada também pelas autarquias, empresas públicas e sociedades de economia mista, na medida em que atuam como suas instrumentalidades.

Como detalhado acima, a Constituição de 1946 estabelecia que a imunidade recíproca abrangia a União, os Estados, o Distrito Federal e os Municípios. Assim, diante da redação adotada pelo dispositivo constitucional, era possível argumentar que apenas essas pessoas políticas estavam alcançadas pela desoneração e não as suas instrumentalidades.

No entanto, já naquela época, o STF reconheceu que tal benefício alcançava também as autarquias e os bens patrimoniais destas no que diz respeito aos impostos estaduais e municipais ${ }^{175}$. Esse entendimento foi, inclusive, consolidado por meio da Súmula $\mathrm{n}^{\mathbf{0}} 73$, aprovada em 13.12.1963, a qual reconheceu que a imunidade das autarquias estava implicitamente contida no art. 31, V, “a”, da Constituição Federal de $1946{ }^{176}$. Para o STF, referida imunidade abrangia inclusive os imóveis que haviam sido objeto de promessa de venda a particulares, conforme consagrado na Súmula $\mathrm{n}^{\circ} 74$ daquele Tribunal ${ }^{177}{ }^{178}$.

Argumentava o Tribunal que a imunidade recíproca amparava não só as entidades públicas citadas pela Constituição, mas também os seus serviços descentralizados, ainda que possuíssem personalidade jurídica própria, incluindo assim na desoneração as autarquias.

Por outro lado, a Corte negou imunidade às sociedades de economia mista, ao argumento de que o benefício não poderia alcançar as pessoas de Direito Privado. Esse entendimento foi consolidado na Súmula $n^{\circ} 76$, que previa que "as sociedades de economia mista não estão protegidas pela imunidade fiscal do art. 31 , V, 'a', da Constituição Federal".

\footnotetext{
${ }^{175} \mathrm{RE} \mathrm{n}^{\mathrm{o}}$ 68.873/GB, $1^{\mathrm{a}}$ Turma, Rel. Min. ALIOMAR BALEEIRO, DJ 24.04.1970; RE n ${ }^{\circ}$ 68.886/GB, $1^{\mathrm{a}}$ Turma, Rel. Min. ALIOMAR BALEEIRO, DJ 24.04.1970; RE ${ }^{\circ}$ 70.268/GB, $1^{\mathrm{a}}$ Turma, Rel. Min. ALIOMAR BALEEIRO, DJ 02.10.1970; e RE nº 69.483 EDv/SP, Pleno, Rel. Min. BILAC PINTO, DJ 27.11.1970.

176 Súmula 73: "A imunidade das autarquias, implicitamente contida no art. 31, V, 'a', da Constituição Federal, abrange tributos estaduais e municipais".

177 Súmula 74: “O imóvel transcrito em nome de autarquia, embora objeto de promessa de venda a particulares, continua imune de impostos locais".

178 Posteriormente, a Emenda Constitucional no 01/1969 estabeleceu expressamente em seu art. 19, $\S 1^{\circ}$, que a imunidade recíproca não exonerava o promitente comprador da obrigação de pagar imposto sobre o imóvel objeto de promessa de compra e venda.
} 
Pois bem. Com a edição da Emenda Constitucional n ${ }^{\circ}$ 18/1965, a imunidade recíproca foi estendida expressamente às autarquias, no que toca ao patrimônio, à renda e aos serviços vinculados às suas finalidades essenciais ou delas decorrentes (art. $2^{\circ}, \S 1^{\circ}$ ).

No entanto, a matéria tornava-se complexa nos casos em que a autarquia atuasse na produção e comercialização de mercadorias. Isso porque previa o art. 58, § $4^{\circ}$, do Código Tributário Nacional, na redação dada pelo Ato Complementar no 34, de $1967^{179}$ :

\begin{abstract}
Art. 58. $\S 4^{\circ}$ Os órgãos da administração pública centralizada e as autarquias e empresas públicas, federais, estaduais ou municipais, que explorem ou mantenham serviços de compra e revenda de mercadorias, ou de venda ao público de mercadoria de sua produção, ainda que exclusivamente ao seu pessoal, ficam sujeitos ao recolhimento do imposto sobre circulação de mercadorias.
\end{abstract}

O STF foi instado a examinar a questão quando do julgamento dos Mandados de Segurança de $\mathrm{n}^{\circ} 18.809^{180}, 18.991^{181}$ e $19.097^{182}$, impetrados pelo Instituto Brasileiro do Café (I.B.C.). Naquela ocasião, discutia-se sobre a possibilidade de cobrança de ICM pelo Estado de Minas Gerais sobre as operações de venda de café realizadas pelo I.B.C.

Em seu voto, ressaltou BALEEIRO que a pessoa política de Direito Público amparada pela imunidade poderia abrir mão desse direito e sujeitar-se ao imposto de outra, desde que isso fosse feito por meio de lei, como, por exemplo, nos casos em que o ente pretendesse manter um regime competitivo com as empresas privadas do mesmo setor.

No entanto, ressaltou BALEEIRO, esse não era o caso do I.B.C., tendo em vista que esse instituto exercia um importante papel, como agente da União, na política de comercialização externa do café, atuando no controle do comércio exterior e no balanço de pagamentos, agindo assim não como empresa comercial, mas como verdadeira "autoridade". Diante dessas circunstâncias, não seria possível admitir que os Estados tributassem suas operações, sob pena de comprometer suas atividades, sendo necessário afastar-se a disposição do art. 58, $\S 4^{\circ}$, do Código Tributário Nacional para reconhecer a imunidade tributária.

Com base nesses argumentos, decidiu o STF pela aplicação da imunidade.

Posteriormente, o STF veio a reconhecer a imunidade das empresas públicas e das sociedades de economia mista, quando estas estivessem voltadas à prestação de serviços públicos. Com efeito, embora assumam a forma de pessoas jurídicas de Direito Privado, tais

\footnotetext{
${ }^{179}$ O dispositivo foi posteriormente revogado pelo Decreto-lei $\mathrm{n}^{\circ} 406$, de 1968.

${ }^{180} \mathrm{MS} \mathrm{n}^{\circ}$ 18.809/DF, Pleno, Rel. Min. ALIOMAR BALEEIRO, DJ 08.07.1976.

${ }^{181} \mathrm{MS} \mathrm{n}^{\circ}$ 18.991/DF, Pleno, Rel. Min. ALIOMAR BALEEIRO, DJ 08.07.1976.

${ }^{182} \mathrm{MS} \mathrm{n}^{\circ}$ 19.097/DF, Pleno, Rel. Min. OSWALDO TRIGUEIRO, DJ 08.07.1976.
} 
empresas atuam como instrumentalidades dos entes federados, estando abrangidas pela referência constitucional à União, aos Estados, ao Distrito Federal e aos Municípios.

Opôs-se a esse entendimento a previsão contida no art. $150, \S 3^{\circ}$, da Constituição Federal brasileira, segundo o qual a imunidade recíproca não poderia ser aplicada "ao patrimônio, à renda e aos serviços, relacionados com exploração de atividades econômicas regidas pelas normas aplicáveis a empreendimentos privados, ou em que haja contraprestação ou pagamento de preços ou tarifas pelo usuário", vez que as empresas estatais cobram preços pelos serviços e mercadorias ofertados aos seus usuários.

Ademais, ressaltou-se o disposto no art. $173, \S 2^{\circ}$, do Texto Constitucional, o qual estabelece que as empresas públicas e as sociedades de economia mista não podem gozar de privilégios fiscais não extensivos às empresas do setor privado.

No entanto, veio a prevalecer a posição de que tais dispositivos devem ser lidos tendo em vista as atividades desenvolvidas pelas empresas estatais. Com efeito, é necessário distinguir as empresas públicas e as sociedades de economia mista voltadas à exploração de atividades econômicas daquelas voltadas à prestação de serviços públicos. Se no primeiro caso a imunidade não pode ser reconhecida, sob pena de favorecer indevidamente a empresa no mercado, no segundo caso o reconhecimento da imunidade é providência que se impõe, ainda que a sociedade em questão cobre preços ou tarifas dos seus usuários.

Como ressalta ROQUE CARRAZZA, as empresas estatais delegatárias de serviços públicos atuam como verdadeira longa manus do Estado, agindo em nome do Estado para a consecução do interesse público. Assim, apenas quanto à forma são pessoas de Direito Privado, vez que, quanto ao fundo, são pessoas administrativas, instrumentos do Estado ${ }^{183}$.

Ademais, como salienta o autor, a contraprestação recebida pelas empresas prestadoras de serviços públicos nunca é adequada para remunerar os seus serviços, visto que ela não é definida livremente pela empresa, mas sim regulada por lei ou por ato do Executivo. Outrossim, tais empresas não possuem liberdade para recusar a prestação de determinado serviço $^{184}$. Logo, seu regime tributário não pode ser equiparado ao das empresas privadas.

Frise-se que o conceito de "serviço público" aqui utilizado deve ser encontrado no próprio ordenamento. Assim, o que faz com que um serviço seja público é o regime jurídico a

${ }^{183}$ CARRAZA, Roque. A Imunidade Tributária das Empresas Estatais Delegatárias de Serviços Públicos, pp. 38-41.

${ }^{184}$ Ibidem, p. 32. 
que ele está sujeito. Serviço público então é aquele que, em virtude da sua regulamentação, é indisponível e deve ser exercido pelo Estado. É, portanto, um ônus e não uma faculdade ${ }^{185}$.

Assim, como conclui ÁvilA, para que haja o reconhecimento da imunidade é necessária a presença de três requisitos: (i) haja serviço público delegado; (ii) a entidade que exerce o serviço seja um poder público (isto é, o Estado ou uma de suas instrumentalidades); e (iii) o serviço seja prestado por um ente que não persegue uma finalidade econômica ${ }^{186}$.

Diante disso, as empresas públicas e as sociedades de economia mista que prestam serviços públicos e que, portanto, não perseguem interesses econômicos, mas sim a consecução de fins públicos, também estão alcançadas pela imunidade recíproca.

Com base nesse entendimento, o STF reconheceu que a imunidade recíproca aplicava-se à Empresa Brasileira de Correios e Telégrafos - ECT, ao argumento de que a ECT é uma empresa prestadora de serviços públicos, os quais devem ser objeto de prestação obrigatória e exclusiva do Estado e, portanto, não podem ser alcançados por impostos ${ }^{187}$.

A imunidade também foi reconhecida à Empresa Brasileira de Infraestrutura Aeroportuária - INFRAERO, uma vez que tal empresa pública executa, como atividade-fim, em regime de monopólio, serviços de infraestrutura aeroportuária constitucionalmente outorgados à União Federal, conforme art. 21, inciso XII, "c", da Constituição.

Quanto ao art. 150, § $3^{\circ}$, da Constituição, entendeu o STF que a submissão ao regime jurídico das empresas privadas, inclusive quanto aos direitos e obrigações tributárias, somente se justificaria, como decorrência do princípio da livre concorrência, quando as empresas governamentais explorassem atividade econômica em sentido estrito, não se aplicando, por esse motivo, a disciplina prevista no art. $173, \S 1^{\circ}$, da Constituição às empresas públicas e às sociedades de economia mista que sejam delegatárias de serviços públicos ${ }^{188}$.

O STF também reconheceu que as empresas voltadas às atividades de serviço público de água e esgoto estariam abrangidas pela imunidade recíproca, tendo em vista que são prestadoras de serviço público obrigatório e de competência exclusiva do Estado ${ }^{189}$.

\footnotetext{
185 Ibidem, p. 33.

186 ÁVILA, Humberto. Sistema Constitucional Tributário, p. 278.

${ }^{187} \mathrm{RE} \mathrm{n}^{\mathrm{o}}$ 407.099/RS, $2^{\mathrm{a}}$ Turma, Rel. Min. CARLOS VELLOSO, DJ 06.08.2004; RE $\mathrm{n}^{\mathrm{o}} 398.630 / \mathrm{SP}, 2^{\mathrm{a}}$ Turma, Rel. Min. CARLOS VELlOSO, DJ 17.09.2004; ACO n 765/RJ, Pleno, Rel. p/ acórdão Min. MENEZES DIREITO, DJe 03.09 2009; ACO nº 803 TAR-QO/SP, Pleno, Rel. Min. CELSO DE MELLO, DJe 26.09.2011, dentre outros.

${ }^{188}$ Vide RE $\mathrm{n}^{\mathrm{o}}$ 363.412 AgR/BA, 2 $2^{\mathrm{a}}$ Turma, Rel. Min. CELSO DE MELLO, DJe 18.09.2008 e RE $\mathrm{n}^{\circ} 524.615$ AgR/BA, 2 ${ }^{a}$ Turma, Rel. Min. EROS GRAU, DJe 02.10.2008. Em 2011, essa jurisprudência foi confirmada no julgamento do ARE $n^{\circ}$ 638.315 RG/BA (DJe 30.08.2011) com repercussão geral.

${ }^{189} \mathrm{AC} \mathrm{n}^{\mathrm{o}}$ 1.851 QO/RO, $2^{\mathrm{a}}$ Turma, Rel. Min. ELLEN GRACIE, DJe 31.07.2008; RE no 399.307 AgR/MG, $2^{\mathrm{a}}$ Turma, Rel. Min. JOAQUIM BARBOSA, DJe 29.04.2010; e RE nº 482.814 AgR/SC, $2^{\text {a }}$ Turma, Rel. Min. RICARDO LEWANDOWSKI, DJe 13.12.2011.
} 
A imunidade recíproca também foi aplicada ao Hospital Nossa Senhora da Conceição, ao argumento de que a prestação de ações e serviços de saúde por sociedades de economia mista corresponderia à própria atuação do Estado, desde que a empresa estatal não tivesse por finalidade a obtenção de lucro. Assim, concluiu o STF que as sociedades de economia mista, que fossem prestadoras de ações e serviços de saúde e cujo capital social fosse majoritariamente estatal, gozariam da imunidade tributária recíproca ${ }^{190}$.

A imunidade também foi reconhecida à Ordem dos Advogados do Brasil, ao fundamento de que a $\mathrm{OAB}$ desempenha atividades próprias do Estado, tais como a defesa da Constituição, da ordem jurídica do Estado Democrático de Direito, dos direitos humanos e da justiça social, bem como a seleção e o controle disciplinar dos advogados ${ }^{191}$. O mesmo entendimento foi aplicado aos conselhos de fiscalização de profissões regulamentadas, os quais têm natureza jurídica de direito público autárquico ${ }^{192}$.

Por outro lado, a imunidade foi negada à Caixa de Assistência dos Advogados, ao argumento de que esta não desempenharia as atividades inerentes à $\mathrm{OAB}$, sendo apenas uma entidade destinada a prover benefícios pecuniários e assistenciais a seus associados ${ }^{193}$.

A imunidade recíproca também foi negada à Petróleo Brasileiro S.A PETROBRAS, ao argumento de que o monopólio das atividades de pesquisa e lavra do petróleo não transformaria tais atividades em um serviço público inerente à estrutura política da União. Tratar-se-ia apenas de um monopólio legalizado para proteger o interesse geral envolvido em tais atividades ${ }^{194}$.

Esse entendimento foi confirmado no julgamento do RE $n^{\circ} 285.716 \mathrm{AgR} / \mathrm{SP}$, no qual os Ministros do STF ressaltaram que a circunstância de a atividade desempenhada estar ou não sujeita a monopólio estatal era irrelevante para definir a aplicação da imunidade recíproca. Diante disso, concluiu o Tribunal que a imunidade não poderia ser aplicada ao caso, eis que a PETROBRAS atua em benefício de seus acionistas, e a desoneração não se presta a proteger aumento patrimonial dissociado de interesse público primário ${ }^{195}$.

Como se pode ver, o STF sempre adotou um critério claro de distinção para fins de reconhecimento da imunidade: as empresas públicas e sociedades de economia mista que

\footnotetext{
${ }^{190} \mathrm{RE} \mathrm{n}^{\circ}$ 580.264/RS, Pleno, Rel. p/ acórdão Min. AYRES BRITTO, DJe 05.10.2011.

${ }^{191} \mathrm{RE} \mathrm{n}^{\mathrm{o}}$ 259.976 AgR/RS, 2a Turma, Rel. Min. JOAQUIM BARBOSA, DJe 29.04.2010.

${ }^{192} \mathrm{RE} \mathrm{n}^{\circ}$ 643.414 AgR/CE, $1^{\mathrm{a}}$ Turma, Rel. Min. DIAS TOFFOLI, DJe 19.02.2013.

${ }^{193} \mathrm{RE} \mathrm{n}^{\text {o }}$ 233.843/MG, $2^{\mathrm{a}}$ Turma, Rel. Min. JOAQUIM BARBOSA, DJe 17.12.2009; e RE no 662.816 AgR/BA,

$1^{\text {a }}$ Turma, Rel. Min. LUIZ FUX, DJe 26.03.2012.

${ }^{194} \mathrm{RE} \mathrm{n}^{\mathrm{o}} 75.000 / \mathrm{SP}, 1^{\mathrm{a}}$ Turma, Rel. Min. ANTONIO NEDER, DJ 20.06.1980.

${ }^{195} \mathrm{RE} \mathrm{n}^{\mathrm{o}}$ 285.716 AgR/SP, 2a Turma, Rel. Min. JOAQUIM BARBOSA, DJe 25.03.2010.
} 
prestassem serviços públicos e não estivessem voltadas ao atendimento de interesses privados fariam jus à imunidade recíproca e, para as demais, a imunidade deveria ser afastada. 


\subsection{Atividades Abrangidas pela Imunidade.}

Ocorre que, com o passar dos anos, ficou cada vez mais claro que a adoção do critério exposto acima não era suficiente para definir a abrangência da imunidade recíproca.

Isso porque muitas das autarquias, empresas públicas e sociedades de economia mista existentes no Brasil não exercem apenas um tipo de atividade, mas têm uma estrutura complexa. Com efeito, há muitos casos em que a mesma entidade exerce atividades de natureza pública e, ao mesmo tempo, atua na exploração de empreendimentos comerciais.

Diante disso, passou-se a questionar a abrangência da imunidade em tais casos: se deveria alcançar todas as atividades da pessoa jurídica ou apenas seus serviços públicos.

Conforme exposto nos itens anteriores, a jurisprudência norte-americana desde o seu início desenvolveu a concepção de que a imunidade recíproca dos Estados alcançava apenas as atividades de exercício de poderes governamentais e não as hipóteses em que este atuasse como um empreendedor privado (private business ou proprietary character).

Tal diferenciação justifica-se, uma vez que, se no primeiro caso não podemos falar em capacidade econômica, no segundo há nítida capacidade para arcar com o pagamento de tributos, tendo em vista que a exploração de atividades comerciais constitui fato econômico, signo presuntivo de riqueza. Ademais, aplicar a imunidade a tais atividades corresponderia a um privilégio injustificado, eis que favoreceria o Estado no mercado, ensejando concorrência desleal entre os entes públicos e as empresas do setor privado.

Diante disso, já afirmava BALEEIRO que o "patrimônio" alcançado pela imunidade recíproca abrangia todos os bens e coisas vinculadas à propriedade pública e integrantes do serviço público, móveis ou imóveis, corpóreas ou incorpóreas. Por sua vez, as "rendas" abarcariam não somente os tributos arrecadados pelos entes públicos, mas também os preços públicos provenientes do exercício das suas funções, da venda dos seus bens e da utilização dos seus serviços. Por fim, os "serviços" abrangeriam apenas os serviços públicos ${ }^{196}$.

Dessa forma seria possível distinguir o patrimônio, as rendas e os serviços vinculados às atividades fundamentais da pessoa de Direito Público, realizadas na esfera das atribuições de sua competência e como instrumentos desta, dos bens, rendas e serviços alheios a essa competência. Para BALEEIRO, na esteira da distinção entre government e proprietary,

${ }^{196}$ BALEEIRO, Aliomar. Limitações Constitucionais ao Poder de Tributar, p. 410. 
apenas os primeiros fariam jus à imunidade, ao passo que os últimos, por não estarem vinculados a atividades públicas, não seriam beneficiados pela desoneração tributária ${ }^{197}{ }^{198}$.

O mesmo raciocínio é aplicado às autarquias. Assim, para BALEEIRO, a imunidade pode ser aplicada apenas àquilo que seja funcional ou instrumental para a autarquia, é dizer, a todos os bens, rendas ou serviços que sejam utilizados no desempenho de serviços públicos ou nas atividades que sejam da competência específica do governo que a instituiu ${ }^{199}$.

Seguindo esse entendimento, o STF, já em 1972, negou imunidade à Caixa Econômica Estadual no que tange à comercialização de veículos ${ }^{200}$ e, em 1982, afastou a imunidade da Caixa no que diz respeito às atividades de frigorífico por ela exercidas ${ }^{201}$.

Ocorre que muitos serviços públicos são prestados por empresas públicas e sociedades de economia mista não em regime de monopólio, mas em concorrência com empresas privadas. Assim, nesse último caso, é necessário verificar se o reconhecimento da imunidade a tais serviços não acarreta distorções ou desequilíbrios no livre mercado.

Com efeito, a imunidade recíproca deve ser interpretada no contexto da Constituição brasileira. E esta Constituição consagra expressamente a proteção da livre concorrência (art. 170, IV) e prevê que as empresas públicas e sociedades de economia mista estarão sujeitas ao mesmo regime tributário das empresas privadas (art. $173, \S \S 1^{\circ}$ e $2^{\circ}$ ). Sendo assim, a imunidade recíproca não deve gerar desequilíbrios no livre mercado.

É importante ressaltar que nenhum tributo é totalmente neutro, no sentido de não provocar qualquer interferência na economia. Toda tributação afeta de certa forma os agentes econômicos. No entanto, como ensina SCHOUERI, ainda assim deve-se buscar a neutralidade tributária, isto é, a neutralidade da tributação em relação à livre concorrência, de maneira que haja um ambiente em que os agentes do mercado tenham iguais condições competitivas ${ }^{202}$.

\footnotetext{
${ }^{197}$ Ibidem, p. 413. 382).

${ }^{199}$ BALEEIRO, Aliomar. Limitações Constitucionais ao Poder de Tributar, p. 420.

${ }^{200} \mathrm{RE} \mathrm{n}^{\mathrm{o}}$ 74.032/GB, $2^{\mathrm{a}}$ Turma, Rel. Min. BILAC PINTO, DJ 16.02.1973.

${ }^{201} \mathrm{AI} \mathrm{n}^{\circ}$ 88.858 AgR/SP, $1^{\mathrm{a}}$ Turma, Rel. Min. RAFAEL MAYER, DJ 05.11.1982.

${ }^{202}$ SCHOUERI, Luis Eduardo. Direito Tributário, p. 333.
}

198 A distinção entre a atividade do Estado como government e como proprietary também é salientada por ROQUE CARRAZZA. Afirma o autor que a imunidade só pode ser reconhecida no primeiro caso, isto é, aos serviços públicos, mas não às atividades econômicas (in A Imunidade Tributária das Empresas Estatais Delegatárias de Serviços Públicos, p. 31). No mesmo sentido MISABEL DERZI, para quem a imunidade recíproca não pode beneficiar particulares e, portanto, não deve alcançar a atividade empresarial do Estado na qual ele persegue o lucro e se submete às regras do Direito Privado (in Limitações Constitucionais ao Poder de Tributar, nota de atualização, p. 403). É o que também salienta LUÍS EDUARDO SCHOUERI, para quem a imunidade deve ser afastada nos casos em que o Estado e suas instrumentalidades abandonam o domínio público e atuam diretamente no setor da economia destinado aos empreendimentos privados (in Direito Tributário, p. 
Assim, o reconhecimento da imunidade recíproca não pode violar a neutralidade da tributação, gerando uma distorção no livre mercado, ao favorecer determinados competidores (no caso, as empresas estatais) relativamente às empresas do setor privado.

Esse tipo de preocupação já tem orientado as decisões mais recentes do STF. De fato, ao analisar a imunidade da Companhia Docas do Estado de São Paulo - CODESP, aquele Tribunal fez um exame detido das características dessa sociedade, das atividades por ela exercidas e do mercado em que atua, a fim de verificar o alcance da imunidade tributária.

Na ocasião, o Relator do caso, Ministro JoAquim BARboSA, sustentou que a aplicação da imunidade tributária recíproca deveria passar por três estágios:

i) a imunidade deveria ser aplicada apenas aos bens, rendas e serviços utilizados na satisfação de objetivos institucionais imanentes do ente federado e cuja tributação pudesse colocar em risco a sua autonomia política, de forma que não poderia ser utilizada como instrumento destinado a dar ao ente condições de contratar em circunstâncias mais vantajosas;

ii) as atividades de exploração econômica, destinadas primordialmente a aumentar o patrimônio do Estado ou de particulares, deveriam ser submetidas à tributação, por configurarem manifestações de riqueza e sua tributação não prejudicar a autonomia política;

iii) a desoneração não poderia ter como efeito colateral relevante a quebra dos princípios da livre concorrência e do exercício de atividade profissional ou econômica lícita.

É interessante observar que, em seu voto, o Ministro JOAQUIM BARBOSA deixou claro que o foco na obtenção de lucro, a transferência do benefício a particular ilegítimo ou a lesão à livre iniciativa e às regras de concorrência poderiam justificar o afastamento da imunidade recíproca, desde que tais circunstâncias fossem comprovadas pela Fiscalização.

Isto é, não bastaria uma alegação genérica de ofensa à livre concorrência. Caberia ao Fisco demonstrar concretamente, diante das circunstâncias do caso, o risco de dano ao mercado. Esse entendimento alinha-se às premissas que adotamos no presente trabalho, isto é, de que deve ser analisada a relação entre as regras de imunidade e os princípios constitucionais não só no plano conceitual, mas também no plano da eficácia, de maneira a verificar quais são as restrições concretas geradas pela imunidade à garantia desses princípios.

No caso analisado, verificou-se que a CODESP era uma instrumentalidade estatal, uma vez que a exploração dos portos marítimos, fluviais e lacustres corresponde a um serviço público. Ademais, foi constatado que seu controle acionário pertence em sua quase totalidade à União $(99,97 \%)$ e não foi apresentado qualquer indício ou prova de que a atividade desenvolvida pela empresa satisfizesse interesse de acúmulo patrimonial público ou privado. 
Desse modo, os dois primeiros requisitos foram preenchidos.

Quanto ao último, verificou-se que a CODESP não possuía concorrentes em sua área de atuação (o Porto de Santos), não havendo assim violação à livre concorrência.

Por fim, o imóvel analisado no precedente em questão era utilizado na atividade fim da CODESP, isto é, na exploração de portos, e não em empreendimentos particulares.

Em virtude desses fatores, concluiu-se que a imunidade deveria ser aplicada ${ }^{203}$.

Com base nos mesmos critérios, a imunidade foi afastada quanto a um imóvel de propriedade da União e afetado à CODESP que havia sido arrendado a particular, eis que o bem era utilizado para fins de exploração econômica com objetivo lucrativo privado, não sendo protegido pela imunidade recíproca, na forma do art. 150, VI, da Constituição ${ }^{204}{ }^{205}$.

A mesma linha de argumentação norteou a aplicação da imunidade recíproca à Casa da Moeda.

Naquela ocasião, discutia-se sobre o reconhecimento da imunidade recíproca quanto aos serviços de composição gráfica prestados pela Casa da Moeda voltados à confecção de papel moeda, moeda metálica, selo postal e fichas telefônicas.

Entendeu o STF que a desoneração poderia atingir apenas as atividades de confecção de papel-moeda, moedas e selos em favor da União, uma vez que tais serviços são públicos e prestados em regime de exclusividade, com base em expressa delegação da União. Por sua vez, a confecção de fichas telefônicas poderia sujeitar-se à incidência tributária, tendo em vista que, nesses casos, a Casa da Moeda atua em regime de livre concorrência com outros agentes do mercado, não podendo gozar de benefícios inextensíveis a esses agentes ${ }^{206}$.

A mesma análise foi feita quando da apreciação da ACO n 2.179/DF (DJe 02.08.2013). Nesse caso, a tutela foi deferida para suspender a exigibilidade dos créditos relativos ao ICMS incidente sobre a importação de máquinas e insumos destinados exclusivamente à prestação do serviço público de fabricação de papel moeda, moeda metálica e impressão de selos postais e fiscais federais e títulos da dívida pública federal. Na ocasião, o

\footnotetext{
203 RE no 253.472/SP, Pleno, Rel. p/ acórdão Min. JOAQUIM BARBOSA, DJe 31.01.2011. O mesmo entendimento foi aplicado nos seguintes julgados: AI $\mathrm{n}^{\circ} 551.556 \mathrm{AgR} / \mathrm{SP}, 2^{\mathrm{a}}$ Turma, Rel. Min. JOAQUIM BARBOSA, DJe 31.03.2011; AI n ${ }^{\circ} 351.888$ AgR/SP, 2 ${ }^{\mathrm{a}}$ Turma, Rel. Min. CELSO DE MELLO, DJe 19.08.2011; e AI no 558.682 AgR/SP, 2 ${ }^{\mathrm{a}}$ Turma, Rel. Min. JOAQUIM BARBOSA, DJe 18.06.2012. ${ }^{204} \mathrm{AI} \mathrm{n}^{\mathrm{o}}$ 703.831 ED/SP, $2^{\mathrm{a}}$ Turma, Rel. Min. JOAQUIM BARBOSA, DJe 31.01.2011.

205 Atualmente encontra-se pendente de julgamento no STF, com repercussão geral, o RE no 594.015 RG/SP, em que se discute a imunidade quanto ao IPTU de terreno localizado na área portuária de Santos, pertencente à União e ocupado pela PETROBRAS, quando esta estiver na condição de arrendatária da CODESP.

${ }^{206} \mathrm{RE} \mathrm{n}^{\mathrm{o}}$ 592.752 AgR/RJ, $1^{\text {a }}$ Turma, Rel. Min. ROBERTO BARROSO, DJe 11.04.2014.
} 
Ministro JOAQUIM BARBOSA deixou claro que a imunidade recíproca poderia abranger somente os bens destinados especificamente para a prestação do serviço público ${ }^{207}{ }^{208}$.

Ocorre que nem sempre é possível traçar uma distinção clara entre as atividades econômicas e os serviços públicos exercidos por estas entidades, tendo em vista que sua estrutura é cada dia mais complexa. Ademais, verifica-se que, em muitos casos, os entes imunes realizam atividades comerciais justamente com o intuito de custear os seus serviços públicos, que nem sempre são remunerados adequadamente pelas tarifas fixadas pelo Estado.

Em tais hipóteses, o mesmo entendimento deveria ser aplicado, isto é, a imunidade recíproca poderia alcançar apenas os serviços de caráter estritamente público?

Outrossim, a magnitude das atividades econômicas desenvolvidas pela entidade imune teria alguma influência sobre o reconhecimento da imunidade? É dizer, caso a autarquia ou empresa estatal realize atividades econômicas em caráter apenas marginal e sem qualquer impacto na concorrência, a imunidade recíproca ainda assim deveria ser negada?

O exame da relação entre as imunidades tributárias e a livre concorrência jamais pode ser feito de forma meramente abstrata. Isso porque nem sempre o reconhecimento da imunidade recíproca a atividades econômicas pode gerar desequilíbrios na concorrência.

Basta analisar a hipótese de autarquias que alugam alguns de seus imóveis com o objetivo de custear os seus serviços públicos. A imunidade desses imóveis ao IPTU deve ser reconhecida, ainda que estejam vinculados a uma atividade comercial, visto que tal desoneração não poderá gerar qualquer prejuízo à concorrência. Ademais, tributar tais imóveis seria desfalcar o patrimônio e as rendas da entidade, os quais estão integralmente voltados a fins públicos. Diferente seria se a autarquia passasse a alugar dezenas ou centenas de imóveis, em verdadeiro empreendimento comercial, contratando livremente com os agentes do mercado. Nesse caso, a imunidade recíproca deveria ser afastada, sob pena de causar um desequilíbrio nas condições de concorrência com as empresas privadas.

Diante disso, embora seja importante analisar os impactos do reconhecimento da imunidade na livre concorrência, tal análise deve ser feita em concreto e, portanto, deve levar em conta as particularidades da empresa ou autarquia em questão e do mercado em que ela atua, a fim de que possa ser constatado se há um risco real e efetivo de lesão ao livre mercado.

\footnotetext{
${ }^{207}$ Vale salientar que BALEEIRO já defendia a adoção desse critério, no sentido de que a imunidade recíproca dependeria da destinação da mercadoria importada: se ela fosse específica para o serviço público, haveria imunidade, se não, deveria ser tributada (in Limitações Constitucionais ao Poder de Tributar, p. 414).

${ }^{208}$ A imunidade da Casa da Moeda também foi reconhecida nos seguintes julgados: RE ${ }^{\circ}$ 610.517 AgR/RJ, $2^{\mathrm{a}}$ Turma, Rel. Min. CELSO DE MELLO, DJe 20.06.2014; e RE nº 605.908 AgR/RJ, 2a Turma, Rel. Min. CÁRMEN LÚCIA, DJe 06.08.2014.
} 
A jurisprudência do STF também tem evoluído nesse sentido. Com efeito, as decisões daquele Tribunal recorrem cada vez menos a menções genéricas de violação a livre concorrência e cada vez mais a análises concretas das empresas e dos mercados em questão.

No que tange às autarquias, o STF tem entendido que os imóveis alugados por estas entidades também são imunes à tributação pelo IPTU, quando comprovado que as rendas obtidas com a atividade de locação foram destinadas inteiramente a fins públicos ${ }^{209}$.

É importante salientar que nesses casos o Tribunal não fez um exame claro dos impactos do reconhecimento da imunidade na concorrência. No entanto, provavelmente isso se deu em virtude do fato de que a locação de imóveis foi vista como uma atividade marginal e pouco relevante economicamente, não sendo capaz de alterar as condições de mercado.

Por outro lado, no caso de empresas públicas que possuíam um grande porte econômico, tal como os Correios, a matéria foi tratada com maior profundidade pelo STF.

Nesse sentido vale mencionar o julgamento do $\mathrm{RE} \mathrm{n}^{\circ}$ 601.392/PR ${ }^{210}$. Naquela ocasião, discutia-se acerca da abrangência da imunidade da ECT, tendo em vista que essa empresa realiza: (i) atividades postais em regime de exclusividade ${ }^{211}$, (ii) atividades postais em regime de concorrência com as empresas privadas ${ }^{212}$; e (iii) atividades não postais ${ }^{213}$.

\footnotetext{
${ }^{209}$ Vejam-se, nesse sentido, os seguintes julgados: RE n 302.585 AgR/MG, $2^{\text {a }}$ Turma, Rel. Min. CARLOS VELLOSO, DJ 28.10.2004, RE $\mathrm{n}^{\circ}$ 212.370 AgR/MG, $1^{\mathrm{a}}$ Turma, Rel. Min. SEPÚLVEDA PERTENCE, DJ 29.04.2005, $\mathrm{AI} \mathrm{n}^{\mathrm{o}}$ 744.269 AgR/RJ, $1^{\text {a }}$ Turma, Rel. Min. AYRES BRITTO, DJe 05.08.2010.

${ }^{210} \mathrm{RE} \mathrm{n}^{\circ}$ 601.392/PR, Pleno, Rel. p/ acórdão Min. GILMAR MENDES, DJe 04.06.2013.

${ }^{211}$ Tais atividades estão previstas no art. $9^{\circ}$ da Lei $n^{\circ} 6.538 / 78$, que assim dispõe:

“Art. $9^{\circ}$. São exploradas pela União, em regime de monopólio, as seguintes atividades postais:

I - recebimento, transporte e entrega, no território nacional, e a expedição, para o exterior, de carta e cartãopostal;

II - recebimento, transporte e entrega, no território nacional, e a expedição, para o exterior, de correspondência agrupada:

III - fabricação, emissão de selos e de outras fórmulas de franqueamento postal. (...)"

${ }^{212}$ Os serviços postais estão listados no art. $7^{\circ}$ da Lei $n^{\circ} 6.538 / 78$, incluindo os serviços sujeitos ao privilégio da exclusividade, na forma do art. $9^{\circ}$, e os serviços sujeitos à concorrência com as empresas privadas. É ver:

"Art. $7^{\circ}$. Constitui serviço postal o recebimento, expedição, transporte e entrega de objetos de correspondência, valores e encomendas, conforme definido em regulamento.

$\S 1^{\circ}$. São objetos de correspondência:

a) carta;

b) cartão-postal;

c) impresso;

d) cecograma;

e) pequena encomenda.

$\S 2^{\circ}$. Constitui serviço postal relativo a valores:

a) remessa de dinheiro através de carta com valor declarado;

b) remessa de ordem de pagamento por meio de vale-postal;

c) recebimento de tributos, prestações, contribuições e obrigações pagáveis à vista, por via postal.

$\S 3^{\circ}$. Constitui serviço postal relativo a encomendas a remessa e entrega de objetos, com ou sem valor mercantil, por via postal."

${ }^{213}$ Além dos serviços postais propriamente ditos, a ECT pode exercer atividades correlatas e afins. Vejam-se, nesse sentido, os arts. $2^{\circ}$ e $8^{\circ}$ da Lei ${ }^{\circ}$ 6.538/78:
} 
No processo que deu origem ao $\mathrm{RE} \mathrm{n}^{\mathrm{o}}$ 601.392/PR, em particular, buscava o Município de Curitiba tributar por meio do ISS as atividades de venda e resgate de títulos de capitalização (“Tele Sena" e "Papa Tudo"), recebimento de mensalidades do "Carnê do Baú", recebimento de inscrições para concursos e vestibulares, dentre outras, realizadas pela ECT.

Em seu voto, o Ministro Relator JOAQUIM BARBOSA reiterou o entendimento de que a imunidade não poderia beneficiar particulares, alcançando atividades econômicas com intuito lucrativo. Afirmou o Ministro que a imunidade recíproca exercia a função de proteção do pacto federativo, evitando que a tributação fosse um instrumento de coerção de entes federados, e de proteção da atividade desprovida de capacidade contributiva (atividades públicas em sentido estrito). No entanto, ressaltou que a desoneração não poderia beneficiar interesses particulares, nem afetar intensamente a livre iniciativa e a livre concorrência.

Assim, concluiu que, se o ente federado atuasse com intuito preponderantemente lucrativo, a imunidade não pode ser aplicada, eis que a atividade lucrativa constitui signo de capacidade contributiva. Logo, considerando que naquele caso as atividades em análise eram atividades econômicas, entendeu o Relator que a imunidade recíproca deveria ser afastada.

No entanto, ao final prevaleceu o entendimento favorável à imunidade, dada as peculiaridades das atividades desenvolvidas pela ECT, na linha dos votos proferidos pelos Ministros Ayres Britto, Gilmar Mendes, Celso de Mello, Dias Toffoli e Ricardo LEWANDOWSKI.

Argumentaram os Ministros que a imunidade deveria ser reconhecida para todos os serviços postais prestados pela ECT, os quais são serviços públicos por força de determinação constitucional ${ }^{214}$, ainda que prestados em concorrência com empresas privadas.

\footnotetext{
“Art. $2^{\circ}$. O serviço postal e o serviço de telegrama são explorados pela União, através de empresa pública vinculada ao Ministério das Comunicações.

$\S 1^{\circ}$. Compreende-se no objeto da empresa exploradora dos serviços:

a) planejar, implantar e explorar o serviço postal e o serviço de telegrama;

b) explorar atividades correlatas;

c) promover a formação e o treinamento de pessoal sério ao desempenho de suas atribuições;

d) exercer outras atividades afins, autorizadas pelo Ministério das Comunicações.

(...)

Art. $8^{\circ}$ - São atividades correlatas ao serviço postal:

I - venda de selos, peças filatélicas, cupões resposta internacionais, impressos e papéis para correspondência;

II - venda de publicações divulgando regulamentos, normas, tarifas, listas de código de endereçamento e outros assuntos referentes ao serviço postal.

III - exploração de publicidade comercial em objetos correspondência.

Parágrafo único. A inserção de propaganda e a comercialização de publicidade nos formulários de uso no serviço postal, bem como nas listas de código de endereçamento postal, é privativa da empresa exploradora do serviço postal."

${ }^{214}$ A natureza pública dos serviços postais decorreria do art. $21, \mathrm{X}$, da Constituição, o qual prevê que compete à União "manter o serviço postal".
} 
Isso porque a ECT é uma empresa pública e está sujeita aos princípios da continuidade do serviço, da universalização do atendimento e da modicidade tarifária. Assim, a empresa está obrigada a prestar os serviços postais em todo o território nacional, ainda que a prestação lhe seja economicamente desvantajosa, o que não ocorre com as empresas privadas.

Ademais, a empresa não tem liberdade para fixar os seus preços, os quais são fixados por ato do Poder Executivo em atenção à modicidade tarifária ${ }^{215}$. Por fim, a ECT está sujeita a diversas outras restrições não aplicáveis às empresas do setor privado, tais como a obrigatoriedade de realização de licitação prévia para a celebração de contratos, a necessidade de realização de concursos públicos para a contratação de funcionários, dentre outras.

Sendo assim, os regimes jurídicos aplicáveis à ECT e às empresas privadas são radicalmente distintos, estando a primeira sujeita a restrições muito mais graves.

Logo, é inexato afirmar que a imunidade recíproca provocaria um desequilíbrio de concorrência entre a ECT e as empresas do setor privado em tais casos, visto que, desde o início, os Correios e as empresas privadas já não operam em iguais condições no mercado.

Ademais, ainda que a imunidade tributária conferisse uma posição de destaque aos Correios, tal posição não poderia ser utilizada com o objetivo de prejudicar a concorrência ou os consumidores através de práticas predatórias, como o aumento dos preços. Isso porque, como visto, a prestação do serviço e os preços cobrados pela ECT são exaustivamente regulados pelo Estado, de modo que, ainda que seja possível afirmar em tese que haveria um risco de dano à livre concorrência, de fato, tal risco não pode ser demonstrado.

Por fim, quanto às atividades não postais (como a venda e resgate de títulos de capitalização), elas são exercidas em caráter marginal pelos Correios e voltam-se, em grande parte, à obtenção de receitas para custear serviços públicos que se revelam deficitários.

Com efeito, muitos dos serviços postais realizados pela ECT não são adequadamente remunerados pelas tarifas fixadas pela União. Veja-se, a título de exemplo, o serviço da Carta Social, que está sujeito a uma tarifa simbólica de R \$ 0,01 (um centavo), que deve ser aplicada qualquer que seja o destino da carta no território brasileiro.

A existência de tais déficits exige a prática do chamado "subsídio cruzado", de modo que atividades comerciais e mais lucrativas são realizadas pelos Correios com o objetivo de angariar receitas e custear atividades menos lucrativas e de prestação obrigatória.

\footnotetext{
215 Como ressalta CARRAZZA, embora o serviço de entrega de encomendas não esteja submetido ao regime de privilégio, a ECT não pode se negar a realizá-lo, ainda lhe seja economicamente desvantajoso, ao contrário das empresas privadas, assim como não pode fixar o preço do serviço (in A Imunidade Tributária das Empresas Estatais Delegatárias de Serviços Públicos, p. 123).
} 
Tal procedimento não é reprovável, mas antes desejável, uma vez que as empresas estatais devem ser capazes de custear suas despesas sem ter de recorrer aos cofres do Estado.

Por fim, é importante salientar que as atividades econômicas em questão voltamse não apenas à obtenção de receitas, mas também à realização de um programa social.

Com efeito, a venda de títulos de capitalização se insere no Banco Postal, que corresponde a um programa desenvolvido pelo governo federal para a prestação de serviços bancários básicos em todo o território nacional, tendo como objetivo garantir à população de baixa renda e desprovida de atendimento bancário o acesso ao Sistema Financeiro. Assim, se de um lado a venda de títulos de capitalização é uma atividade claramente econômica, de outro lado, não se pode negar o caráter social das atividades inseridas no Banco Postal.

Assim, tendo sido comprovado no RE $\mathrm{n}^{\circ}$ 601.392/PR que as atividades não postais exercidas pela ECT têm caráter apenas marginal e não transfiguram a natureza da empresa e que as receitas com elas obtidas são integralmente aplicadas no custeamento de serviços públicos, reconheceu o STF que a imunidade recíproca também deveria alcançá-las.

Recentemente, esse entendimento foi confirmado no julgamento do RE $n^{\circ}$ 627.051/PE (Pleno, j. em 12.11.2014), no qual foi reconhecida a imunidade dos serviços de transporte de mercadorias realizados pela ECT no que se refere ao ICMS. Novamente, salientou-se a circunstância de que a ECT não está sujeita às mesmas condições aplicáveis às empresas privadas, já que está obrigada a entregar encomendas em todo o território nacional. Ademais, argumentou-se que a ECT faz uso de espaços ociosos nos seus veículos para transportar as mercadorias, de maneira que a empresa não criou uma estrutura específica para competir com empresas particulares, não sendo possível sequer discriminar quais são os valores referentes ao transporte de mercadorias para estabelecer a base de cálculo do imposto.

Desse modo, afirmou o Relator, Ministro DIAS TOFFOLI, que a imunidade recíproca deveria ser reconhecida também para essas atividades "seja pela impossibilidade de se separarem topicamente as atividades concorrenciais, seja por entender que o desempenho delas não descaracteriza o viés essencialmente público de suas atividades institucionais".

Também no julgamento da $\mathrm{ACO} \mathrm{n}^{\circ}$ 819/SE, foi reconhecida a imunidade quanto à cobrança de IPVA sobre os veículos de propriedade da ECT, sem que fosse feita qualquer distinção entre os veículos utilizados nas atividades sujeitas ao regime de exclusividade e aqueles empregados nas demais atividades desenvolvidas pela empresa ${ }^{216}$.

Diante do exposto, é possível traçar algumas conclusões.

${ }^{216}$ ACO 819 AgR-ED/SE, Pleno, Rel. Min. DIAS TOFFOLI, DJe 31.07.2013. 
Em primeiro lugar, a imunidade recíproca deve alcançar os serviços públicos prestados por autarquias, empresas públicas e sociedades de economia mista. No entanto, fazse necessário verificar se tais serviços são prestados em regime de exclusividade ou em regime de concorrência com as empresas privadas. Caso haja concorrência, a imunidade só pode ser reconhecida se não gerar distorções graves à livre concorrência, uma vez que a tributação (e, consequentemente, a desoneração) também deve se pautar pela neutralidade.

Frise-se que falamos aqui em distorções graves ou intensas à concorrência, eis que o reconhecimento de toda imunidade pode produzir um efeito negativo no mercado. No entanto, para que tal efeito tenha o condão de afastar a garantia constitucional, é necessário que ele possa afetar intensamente a livre concorrência e o livre mercado.

Por fim, a princípio, a imunidade recíproca não deve alcançar as atividades econômicas exercidas por estas entidades, eis que tais atividades configuram manifestações de capacidade contributiva e a desoneração não pode ter como objetivo favorecer o aumento patrimonial dos particulares ou do Estado ou provocar uma concorrência desleal no mercado.

Contudo, caso se verifique que as atividades econômicas realizadas pelas instrumentalidades do Estado têm caráter marginal, não podem gerar prejuízos à concorrência e as receitas com elas obtidas são integralmente voltadas ao custeamento de serviços públicos, entendemos que a imunidade recíproca deve ser aplicada também a tais casos, sob pena de desfalcar o patrimônio e as rendas voltadas a consecução de fins perseguidos pelo Estado. 
5. As Imunidades dos Templos, Partidos Políticos, Entidades Sindicais dos Trabalhadores e Instituições de Educação e Assistência Social. 


\subsection{Histórico das Imunidades.}

A desoneração tributária das entidades religiosas, educacionais e assistenciais teve início no ordenamento jurídico brasileiro sob a forma de isenções, e não de imunidades. Assim, previa o art. 28 do Decreto-Lei ${ }^{\circ}$ 5.844/1943 que estavam isentas do imposto de renda "as sociedades e fundações de caráter beneficente, filantrópico, caritativo, religioso, educativo, cultural, instrutivo, científico, artístico, literário, recreativo e esportivo".

Com a promulgação da Constituição de 1946, tal desoneração foi levada ao patamar constitucional, prevendo o art. 31, V, "b", da referida Carta que os entes federados estavam proibidos de lançar impostos sobre templos de qualquer culto, bens e serviços de partidos políticos e das instituições de educação e de assistência social, desde que as suas rendas fossem aplicadas integralmente no país para a realização dos respectivos fins.

O benefício foi mantido pela Constituição de 1967, que segregou tais imunidades, inserindo a desoneração dos templos na alínea "b" do art. 20, III, e a desoneração dos partidos políticos e instituições de educação e de assistência social na alínea "c" do dispositivo. A fruição dessa última imunidade foi condicionada ao atendimento dos requisitos fixados em lei.

A previsão foi mantida pelo art. 19, III, da Emenda Constitucional $n^{\circ}$ 1/1969. Frise-se que, naquela época, a regra constitucional não contemplava qualquer previsão no sentido de que tal imunidade estaria limitada às finalidades essenciais das entidades.

Por sua vez, previu a Constituição Federal de 1988:

Art. 150. Sem prejuízo de outras garantias asseguradas ao contribuinte, é vedado à União, aos Estados, ao Distrito Federal e aos Municípios:

(...)

VI - instituir impostos sobre:

b) templos de qualquer culto;

c) patrimônio, renda ou serviços dos partidos políticos, inclusive suas fundações, das entidades sindicais dos trabalhadores, das instituições de educação e de assistência social, sem fins lucrativos, atendidos os requisitos da lei;

(...)

$\S 4^{\circ}$ - As vedações expressas no inciso VI, alíneas "b" e "c", compreendem somente o patrimônio, a renda e os serviços, relacionados com as finalidades essenciais das entidades nelas mencionadas. (...)

Como se nota, a nova Constituição manteve em alíneas distintas a imunidade dos templos de qualquer culto e a imunidade dos partidos políticos e das instituições de educação 
e assistência social, estabelecendo expressamente que estas não poderiam ter fins lucrativos e que as pessoas listadas na alínea "c" deveriam atender aos requisitos fixados em lei.

Ademais, a nova Constituição acrescentou a imunidade tributária das entidades sindicais dos trabalhadores, bem como a restrição contida no $\S 4^{\circ}$, segundo o qual os benefícios previstos nas alíneas "b" e "c" compreenderiam somente o patrimônio, a renda e os serviços, relacionados com as finalidades essenciais das entidades nelas mencionadas. 


\subsection{Os Requisitos Fixados em "Lei".}

Como visto acima, prevê o art. 150, VI, “c”, da Carta que as entidades nele listadas farão jus à imunidade tributária desde que atendam aos requisitos fixados em lei.

Trata-se de norma constitucional de eficácia contida, na tradicional classificação elaborada por José AFONSO DA SILVA ${ }^{217}$. Como leciona o autor, as normas constitucionais podem ser classificadas, quanto à sua eficácia e aplicabilidade, em três grupos: (i) normas de eficácia plena; (ii) normas de eficácia contida; e (iii) normas de eficácia limitada.

As normas de eficácia plena são aquelas que produzem ou podem produzir, desde a sua entrada em vigor, todos os seus efeitos, tendo em vista que a Constituição estabeleceu desde já uma normatividade suficiente para tanto, incidindo de forma direta e imediata. Já as normas de eficácia contida são aquelas que também incidem imediatamente, mas preveem determinados meios ou conceitos que permitem conter a sua eficácia a certos limites. Por fim, as normas de eficácia limitada são aquelas que não produzem todos os seus efeitos desde a sua entrada em vigor, eis que a Constituição não estabeleceu uma normatividade suficiente sobre a matéria, deixando essa tarefa ao legislador ordinário ou a outro órgão do Estado.

No caso em tela, trata-se de norma de eficácia contida e não limitada. Logo, caso não seja editada lei regulamentando a matéria, a desoneração deverá ser aplicada sem qualquer restrição (exceção feita, é claro, às restrições já previstas pela Constituição).

Editada a lei, as pessoas que queiram fazer jus ao benefício deverão cumprir os requisitos nela fixados. Tais requisitos, evidentemente, terão apenas o condão de regulamentar o preceito constitucional, de modo que não poderão restringir ilegitimamente o benefício concedido pela Constituição, sob pena de se subverter a hierarquia do ordenamento pátrio.

Questão polêmica diz respeito ao instrumento normativo adequado para a fixação de tais requisitos, eis que o art. 150, VI, "c" da Constituição faz referência apenas a "lei", o que poderia ser interpretado como a exigir lei complementar ou apenas lei ordinária.

A discussão é relevante, eis que a lei complementar possui um procedimento específico para sua edição, exigindo aprovação por maioria absoluta, conforme dispõe o art. 69 da Constituição, ao passo que as leis ordinárias podem ser aprovadas por maioria simples.

Para a parcela majoritária da doutrina, os requisitos para fruição da imunidade poderiam ser estabelecidos apenas por meio de lei complementar, em face do que dispõe o art.

217 SILVA, José Afonso da Silva. Aplicabilidade das Normas Constitucionais. $8^{\text {a }}$ ed. São Paulo: Malheiros, 2012, pp. 81-82. 
146 da $\operatorname{Carta}^{218}$. Com efeito, prescreve o referido dispositivo que cabe à lei complementar: (i) dispor sobre conflitos de competência, em matéria tributária, entre os entes federados; (ii) regular as limitações constitucionais ao poder de tributar; e (iii) estabelecer normas gerais em matéria tributária, especialmente sobre a definição de tributos e suas espécies, fatos geradores, bases de cálculo e contribuintes, obrigação, lançamento, crédito, prescrição e decadência tributários, tratamento tributário do ato cooperativo praticado pelas sociedades cooperativas e tratamento diferenciado e favorecido para as microempresas e empresas de pequeno porte.

Diante disso, e considerando que os requisitos para fruição das imunidades tributárias configuram uma regulação das limitações constitucionais ao poder de tributar, enquadrando-se assim no item (ii) citado acima, apenas a lei complementar poderia fixá-los.

Por outro lado, alguns autores sustentam que tais requisitos poderiam ser fixados por lei ordinária. A favor desse entendimento, poder-se-ia argumentar que, nos casos em a Constituição pretendeu exigir a edição de lei complementar, ela o fez de forma expressa.

Assim, a título de exemplo, o art. 146-A da Constituição previu que a lei complementar estabeleceria os critérios especiais de tributação, o art. 148 do mesmo diploma determinou que os empréstimos compulsórios seriam instituídos "mediante lei complementar", o art. 153 estabeleceu que o imposto sobre grandes fortunas poderia ser instituído "nos termos de lei complementar" e o art. 156 dispôs que os Municípios poderiam instituir imposto sobre serviços de qualquer natureza "definidos em lei complementar".

Desse modo, seguindo esse entendimento e considerando que o art. 150, VI, "c" fez referência apenas à lei, os requisitos poderiam ser fixados pela via da lei ordinária.

A favor do emprego da lei ordinária já se manifestaram ALIOMAR BALEEIRO ${ }^{219} \mathrm{e}$ ManOel GonÇAlves FerReIRA FilHO ${ }^{220}$. Frise-se, no entanto, que, para GilbERTO DE UlhôA CANTO, a posição de FERREIRA FILHO tem sido mal compreendida pela doutrina, eis que esse autor não teria defendido que todo e qualquer requisito pudesse ser fixado em lei ordinária.

Afirma UlhôA CANTO que um exame mais acurado dos comentários de FERREIRA FILHO sugere que a sua opinião não era a de que a lei ordinária poderia fixar os requisitos para

\footnotetext{
${ }^{218}$ Vale mencionar, dentre outros, os seguintes autores: IVES GANDRA DA SILVA MARTINS, HUGO DE BRITO MACHADO, BERNARDO RIBEIRO DE MORAES, LUCIANO AMARO, AIRES FERNANDINO BARRETO, SACHA CALMON NAVARRO COELHO e JOSÉ EDUARDO SOARES DE MELO (in MARTINS, Ives Gandra da Silva (coord.). Imunidades Tributárias, pp. 45, 91, 139-140, 149, 171, 228 e 368, respectivamente).

219 BALEEIRO, Aliomar. Limitações Constitucionais ao Poder de Tributar, p. 505. No mesmo sentido: BALEEIRO, Aliomar. Direito Tributário Brasileiro. 12 a ed. Rio de Janeiro: Forense, 2013 , p. 222.

${ }^{220}$ FERREIRA FILHO, Manoel Gonçalves. Comentários à Constituição Brasileira. $5^{\mathrm{a}}$ ed. São Paulo: Saraiva, 1984, p. 154.
} 
o gozo da imunidade, mas sim a de que essa lei disporia sobre os aspectos configuradores do que são instituições assistenciais e educacionais, como forma de coibir abusos e fraudes ${ }^{221}$.

E, de fato, parte da doutrina brasileira traça uma distinção entre duas espécies de requisitos que devem ser cumpridos pelas pessoas que pretendam fazer jus à imunidade. Uma delas deveria ser fixada pela via complementar e outra poderia ser prevista por lei ordinária.

Nesse sentido posiciona-se RICARDO LOBO TORRES ${ }^{222}$. Para o autor, à lei complementar cabe fixar os requisitos de legitimação ao exercício do direito à imunidade, como a obrigação de que as entidades apliquem os recursos integralmente no país, ao passo que à lei ordinária cabe estabelecer as condições para a existência da pessoa imune e para sua legalização.

O STF ainda não tem um posicionamento definitivo sobre a matéria.

No entanto, quando do julgamento da medida cautelar requerida nos autos da ADI $\mathrm{n}^{\mathrm{o}}$ 1.802/DF $\mathrm{DF}^{223}$, o Tribunal indicou que poderá adotar uma posição intermediária. Com efeito, naquela ocasião, afirmou o STF que a Constituição brasileira teria remetido à lei ordinária apenas a fixação de normas sobre a constituição e o funcionamento das entidades imunes, ao passo que a definição dos "lindes da imunidade", isto é, quais são o patrimônio, as rendas e os serviços abarcados pela imunidade, teria ficado reservada à disciplina da lei complementar.

A discussão foi levada a julgamento no STF em virtude da edição da Lei federal $\mathrm{n}^{\circ}$ 9.532/1997, que estabeleceu diversos requisitos para fruição da imunidade em tela.

$\mathrm{Na}$ ADI n $1.802 \mathrm{MC} / \mathrm{DF}$, entendeu o STF que, em uma análise preliminar, não padeciam de inconstitucionalidade formal os requisitos estabelecidos pela Lei $n^{\circ}$ 9.532/1997, salvo aquele fixado no art. $12, \S 2^{\circ}$, "f", o qual previa que as entidades deveriam recolher os tributos retidos sobre os rendimentos por elas pagos ou creditados e a contribuição para a Seguridade Social relativa aos empregados e cumprirem as obrigações acessórias decorrentes.

Isso porque tal dispositivo seria uma norma sancionatória de responsabilidade e instituidora de obrigações tributárias, e não uma norma para fixação dos requisitos subjetivos para a configuração de uma entidade imune. Assim, considerando que a matéria nele versada é reservada à lei complementar (art. 146, III), sua constitucionalidade poderia ser questionada.

\footnotetext{
${ }^{221}$ CANTO, Gilberto de Ulhôa. A Imunidade Tributária das Entidades Fechadas de Previdência Privada. São Paulo, São Paulo: ABRAPP, 1985, p. 34.

222 TORRES, Ricardo Lobo. Imunidades Tributárias. In: MARTINS, Ives Gandra da Silva (coord.). Imunidades Tributárias, pp. 204 e ss.

${ }^{223}$ ADI n ${ }^{\circ}$ 1.802 MC/DF, Pleno, Rel. Min. SEPÚLVEDA PERTENCE, j. em 27.08.1998.
} 
Também entendeu o STF que poderia ser questionada a constitucionalidade formal e material do art. $12, \S 1^{\circ}$, que excluiu do âmbito da imunidade "os rendimentos e ganhos de capital auferidos em aplicações financeiras de renda fixa ou de renda variável”.

Ademais, foi suscitada a inconstitucionalidade formal do art. 13, caput, e do art. 14 da Lei $n^{\circ}$ 9.532/1997, por autorizarem a suspensão da imunidade por ato da Secretaria da Receita Federal em virtude da prática de infrações à legislação tributária. De acordo com o STF, a previsão de tal sanção (suspensão) escaparia à competência do legislador ordinário.

A mesma linha de raciocínio tem sido seguida pelo STF quando se trata de interpretar o $\$ 7^{\circ}$ do art. 195 da Constituição, que estabelece a imunidade quanto às contribuições para a Seguridade Social das entidades beneficentes de assistência social.

Referido dispositivo também prevê que as entidades beneficentes de assistência social devem atender "às exigências estabelecidas em lei”, o que suscitou os mesmos debates na doutrina e na jurisprudência acerca da exigência de lei complementar ou de lei ordinária.

Frise-se que, no caso da imunidade do art. $195, \S 7^{\circ}$, a questão é ainda mais problemática, uma vez que a legislação ordinária que veio a regulamentar a matéria estabelece requisitos muitos mais rígidos para a fruição do benefício, tais como a obrigação de que as entidades de saúde ofertem a prestação de seus serviços ao Sistema Único de Saúde (SUS) no percentual mínimo de $60 \%$ e de que as entidades de educação concedam anualmente bolsas de estudo na proporção de uma bolsa de estudo integral para cada cinco alunos pagantes ${ }^{224}$.

Embora o STF ainda não tenha se pronunciado exaustivamente sobre esse tema, no julgamento do RE $n^{\circ}$ 636.941/RS ${ }^{225}$, o Tribunal decidiu com repercussão geral que a Constituição somente exige lei complementar para a definição dos limites objetivos (materiais) das imunidades tributárias e não para a fixação das normas de constituição e funcionamento das entidades imunes (aspectos formais ou subjetivos), os quais poderiam ser veiculados por lei ordinária, sem que haja ofensa ao art. 146, II, da Constituição ${ }^{226}$.

A conclusão é particularmente perigosa, vez que a fixação de certos requisitos ditos "formais" ou "subjetivos" pode trazer sérias restrições ao alcance da imunidade.

Com efeito, o que se percebe é que as leis ordinárias, sob a alegação de que estariam fixando requisitos para a constituição e o funcionamento das entidades imunes, então na realidade criando verdadeiras limitações materiais à aplicação da desoneração tributária.

\footnotetext{
${ }^{224}$ Os requisitos foram estabelecidos pela Lei ${ }^{\circ} 12.101$, de 27 de novembro de 2009.

${ }^{225}$ RE no 636.941/RS, Pleno, Rel. Min. LUIZ FUX, DJe 03.04.2014.

${ }^{226}$ No mesmo sentido: RE n ${ }^{\circ}$ 594.914 AgR/RS, $1^{\text {a }}$ Turma, Rel. Min. ROBERTO BARROSO, DJe 11.04.2014.
} 
A título de exemplo, determina a Lei $\mathrm{n}^{\circ}$ 12.101/2009 que as entidades só poderão obter o chamado Certificado de Entidade Beneficente de Assistência Social (CEBAS) caso cumpram diversos requisitos nela fixados, incluindo a prestação de um percentual mínimo de serviços ao SUS, o fornecimento de certo número de bolsas de estudos, como visto acima.

Como fica claro, tais normas não regulamentam meramente a "constituição" e o "funcionamento" das entidades imunes, mas limitam materialmente o alcance da imunidade tributária, invadindo assim a competência reservada à lei complementar pelo art. 146, II.

Diante disso, entendemos que apenas a lei complementar pode estabelecer os requisitos para a fruição das imunidades tributárias previstas pela Constituição brasileira.

Por outro lado, cabe à lei ordinária fixar única e exclusivamente os procedimentos necessários para a constituição de sindicatos, partidos políticos e instituições de educação e assistência social, assim como das demais pessoas jurídicas. Esse tipo de previsão, inclusive, já pode ser encontrado hoje no Código Civil, o qual estabelece requisitos para constituição de associações, sociedades e fundações sem fins lucrativos. Isto é, não cabe à lei ordinária fixar qualquer requisito material para o enquadramento da pessoa jurídica como entidade imune, tal como a proibição de que a entidade remunere seus dirigentes pelos serviços prestados ou a fixação de percentuais mínimos de gratuidade para que possam fazer jus ao benefício.

Nesse contexto, conclui-se que o diploma legislativo que estabelece os requisitos para fruição da imunidade prevista no art. 150, VI, "c" da Carta só pode ser o Código Tributário Nacional brasileiro, o qual foi recepcionado pela Constituição de 1988 com o status de lei complementar. Estabelece o CTN em seu art. 14:

\footnotetext{
Art. 14. O disposto na alínea c do inciso IV do artigo $9^{\text {o227 }}$ é subordinado à observância dos seguintes requisitos pelas entidades nele referidas:

I - não distribuírem qualquer parcela de seu patrimônio ou de suas rendas, a qualquer título; (Redação dada pela Lcp no 104, de 10.1.2001)

II - aplicarem integralmente, no País, os seus recursos na manutenção dos seus objetivos institucionais;

III - manterem escrituração de suas receitas e despesas em livros revestidos de formalidades capazes de assegurar sua exatidão.
}

Os requisitos estabelecidos pelo CTN se justificam e estão em conformidade com o disposto na Constituição. Com efeito, por não terem fins lucrativos, as entidades albergadas pela alínea "c" não podem distribuir qualquer parcela do seu patrimônio ou das suas rendas.

\footnotetext{
227 Prescreve o art. 9 ${ }^{\circ}, \mathrm{IV}$, alínea "c" do CTN que é vedado à União, aos Estados, ao Distrito Federal e aos Municípios cobrar imposto sobre o patrimônio, a renda ou serviços dos partidos políticos, inclusive suas fundações, das entidades sindicais dos trabalhadores, das instituições de educação e de assistência social, sem fins lucrativos, reproduzindo assim a disposição contida na Constituição Federal.
} 
Entretanto, isso não equivale a dizer que tais entidades não possam remunerar seus dirigentes, gestores, representantes ou funcionários pelos serviços efetivamente prestados, desde que tal remuneração se dê em padrões compatíveis com o mercado e não corresponda a uma distribuição disfarçada de lucros a particulares ${ }^{228}$.

Atualmente, verifica-se cada vez mais a profissionalização das instituições educacionais e assistenciais, não se podendo esperar que todos os seus funcionários atuem de forma voluntária. Assim, é natural que recebam uma remuneração pelo trabalho realizado.

Também é necessário que tais entidades apliquem integralmente os seus recursos no país na manutenção dos seus objetivos institucionais. E isso é evidente, eis que não se poderia admitir que os recursos beneficiados pela imunidade tributária fossem destinados a outros fins que não as finalidades de interesse público protegidas pelo Texto Constitucional.

Por fim, exige o CTN que as entidades mantenham uma escrituração regular de suas receitas e despesas, tendo em vista que o reconhecimento da imunidade tributária não afasta a necessidade do cumprimento das obrigações acessórias. $\mathrm{O}$ expediente, ademais, é necessário para que o Fisco possa controlar se as receitas alcançadas pela desoneração estão de fato vinculadas às finalidades essenciais dos entes beneficiados pela imunidade.

Definido o alcance da expressão "atendidos os requisitos da lei”, passaremos a analisar as imunidades inseridas no art. 150, VI, "b" e “c”, da Constituição de 1988.

228 Esse é também o entendimento do Conselho Administrativo de Recursos Fiscais (CARF), que tem reconhecido a imunidade nas hipóteses em que as entidades remuneram seus diretores e funcionários em virtude de serviços prestados, e não em decorrência do exercício do cargo de diretoria. Nesse sentido vale conferir os seguintes julgados: Acórdão nº 9101-001.775, j. 16.10. 2013, Acórdão n ${ }^{\circ}$ 2401-003.462, j. 20.03.2014, Acórdão $n^{\circ}$ 103-22.846, j. 24.01.2007, Acórdão n 108-09.420, j. 14.09.2007, e Acórdão nº 101-94.657, j. 12.08.2004. 


\subsection{A Imunidade dos "Templos de Qualquer Culto".}

\subsubsection{Origem e função da imunidade.}

A imunidade dos templos de qualquer culto tem suas origens na Antiguidade, eis que já no Egito os templos e os sacerdotes conquistaram o direito de não pagar tributos ${ }^{229}$.

Também na Idade Média a Igreja católica, assim como os senhores feudais, estava desonerada do pagamento de tributos, embora, para autores como RICARDO LOBO TORRES, não se possa falar nessa época propriamente em imunidade tributária, eis que a Igreja não estava subordinada ao poder real, mas constituía uma fonte autônoma de fiscalidade ${ }^{230}$.

$\mathrm{Na}$ Constituição brasileira, a imunidade dos templos de qualquer culto está relacionada à promoção da liberdade de crença e de culto, assegurada pela Constituição em seu art. $5^{\circ}, \mathrm{VI}$, como direito individual de todos os cidadãos e, portanto, como cláusula pétrea. A imunidade visa evitar que, por meio de imposições tributárias, o Estado exerça pressões para fomentar ou desestimular (ou mesmo inibir) a realização de certas práticas religiosas ${ }^{231}$.

Esse é também o magistério de Luís EDUARDO SCHOUERI, para quem a referida imunidade tributária tem como objetivo assegurar a liberdade de crença e o exercício do culto, uma vez que o Estado não pode adotar medidas que embaracem o funcionamento dos templos. Para o autor, a desoneração tributária em tela também tem como fundamento a ausência de capacidade contributiva, eis que o patrimônio, as rendas e os serviços afetados à atividade religiosa estão fora do domínio econômico e na esfera do domínio público ${ }^{232}$.

No entanto, é importante salientar que a imunidade dos templos de qualquer culto não tem como objetivo subvencionar o exercício religioso, uma vez que o Estado brasileiro é laico. De fato, a Constituição de 1988, repetindo um preceito já contido em constituições anteriores, estabeleceu expressamente em seu art. 19, I, que é vedado à União, aos Estados, ao Distrito Federal e aos Municípios "estabelecer cultos religiosos ou igrejas, subvencioná-los, embaraçar-lhes o funcionamento ou manter com eles ou seus representantes relações de dependência ou aliança, ressalvada, na forma da lei, a colaboração de interesse público".

\footnotetext{
${ }^{229}$ SCHOUERI, Luís Eduardo. Direito Tributário, p. 384.

230 TORRES, Ricardo Lobo. Tratado de Direito Constitucional Financeiro e Tributário, p. 42.

${ }^{231}$ No mesmo sentido HUMBERTO ÁVILA, para quem a imunidade tem como fundamento o dever do Estado de garantia a liberdade religiosa (in Sistema Constitucional Tributário, p. 286).

${ }^{232}$ SCHOUERI, Luís Eduardo. Direito Tributário, p. 387.
} 
Esse ponto terá importância fundamental quando analisarmos o alcance do $\S 4^{\circ}$ do art. 150, tendo em vista que a interpretação dos preceitos que consagram imunidades tributárias jamais poderá ignorar a sua relação com outros direitos inseridos na Constituição.

\subsubsection{Abrangência da imunidade.}

Prevê o art. 150, VI, "b", da Constituição brasileira de 1988 que os entes federados não poderão instituir impostos sobre os "templos de qualquer culto".

Como se pode ver, a redação adotada pela Carta não trouxe muitos detalhes sobre as pessoas e os bens beneficiados pela imunidade, o que faz com que o recurso a argumentos linguísticos não possa responder muitas das questões relativas à interpretação desse preceito.

Quanto ao termo "templo", este poderia ser interpretado como a abranger apenas o prédio principal onde são praticados os cultos, incluindo, por exemplo, as igrejas e as sinagogas, ou poderia abranger outras situações também vinculadas à prática religiosa.

No entanto, se ambas as interpretações são possíveis de acordo com o uso linguístico do termo, apenas a segunda tem o condão de prestigiar o princípio protegido por esta imunidade tributária, pois, para que seja assegurada a liberdade de crença e de culto, é necessário desonerar tudo aquilo que está efetivamente relacionado à atividade religiosa.

Ademais, todo o patrimônio, os serviços e as rendas voltados ao exercício do culto não ostentam capacidade contributiva, tendo em vista que estão fora do domínio econômico.

Diante disso, a conclusão de ALIOMAR BALEEIRo é precisa quando afirma que a expressão constitucional "templos de qualquer culto" não designa apenas a materialidade do edifício, uma vez que ele só se transforma em "templo" se o completam as instalações adequadas a esse fim ou se o utilizam efetivamente no culto ou na prática religiosa.

Sendo assim, de acordo com esse autor, o termo "templo" compreende o próprio culto e tudo quanto vincula o órgão à função. Logo, o templo não seria apenas a igreja, a sinagoga ou o edifício principal, onde se celebra a cerimônia pública, mas também a dependência acaso contígua, o convento, os anexos por força de compreensão, incluindo a casa ou residência do pároco ou pastor, desde que não sejam empregados em fins econômicos. Ademais, poderiam ser equiparados aos templos também a embarcação, o veículo, o vagão, bem como o avião usado como templo móvel exclusivamente para a prática do culto ${ }^{233}$.

${ }^{233}$ BALEEIRO, Aliomar. Limitações Constitucionais ao Poder de Tributar, p. 502. 
No mesmo sentido o entendimento de RICARDO LOBO TORRES. Ensina esse autor que a expressão "templos de qualquer culto" designa um conceito espiritual, que não equivale apenas ao prédio onde se pratica o culto, mas se identifica com a própria religião.

Desse modo, para LOBO TORRES, a imunidade prevista no art. 150, VI, "b" da Constituição abrange o prédio onde se pratica o culto, o lugar da liturgia, o convento, a casa do padre ou do ministro, o cemitério e os aviões e embarcações usadas na catequese. Por outro lado, estariam excluídos os bens utilizados em finalidades econômicas e comerciais, as mercadorias vendidas a terceiros, as terras improdutivas e os terrenos isolados da igreja ${ }^{234}$.

A jurisprudência brasileira também tem adotado um conceito amplo de "templo", de modo a abranger tudo aquilo que está vinculado ao exercício do culto. A título de exemplo, vale mencionar o acórdão proferido pelo STF no julgamento do $\mathrm{RE}^{\circ}{ }^{\circ} 578.562 / \mathrm{BA}^{235}$, no qual foi reconhecida a imunidade ao IPTU dos cemitérios de entidades religiosas.

Frise-se que, naquela ocasião, o Ministro Relator EROS GRAU deixou claro que a imunidade não se aplicava a qualquer cemitério, mas apenas àqueles que consubstanciam extensões de entidades de cunho religioso. Estariam excluídas, portanto, da imunidade as hipóteses de empresas que exploram a atividade de locação e/ou venda de jazigos.

Essa matéria também foi analisada pelo STF nos autos do RE n ${ }^{\circ} 544.815 / \mathrm{SP}$, processo no qual se discutia sobre a possibilidade de tributação pelo IPTU de imóvel pertencente a um particular e alugado a empresa que o explorava como cemitério privado.

Em sessão realizada em 21.05.2008, o Ministro Relator JOAQUIM BARBOSA votou pelo afastamento da imunidade, ao argumento de que a palavra "templo" abrangeria apenas os anexos e outras construções nos quais a entidade religiosa desempenhasse suas atividades essenciais, mas não os terrenos explorados comercialmente por entidades não eclesiásticas, para fins que não são próprios à expressão da crença. O Relator foi acompanhado pelos Ministros CARmÉn Lúcia, RicARdo Lewandowski, CeZar Peluso e Marco Aurélio.

A favor do reconhecimento da imunidade tributária votou o Ministro CARLOS BRITTO, para quem a expressão "templos de qualquer culto" teria grande abrangência, alcançando também o cemitério, por ser um local de reverência, adoração e veneração de pessoas queridas, preponderando nesses casos o elemento religioso sobre o econômico ${ }^{236}$.

$\mathrm{O}$ entendimento manifestado pela maioria dos julgadores é adequado, tendo em vista que os cemitérios devem ser protegidos pela desoneração apenas quando estiverem

\footnotetext{
234 TORRES, Ricardo Lobo. Tratado de Direito Constitucional Financeiro e Tributário, pp. 253-255.

${ }^{235}$ RE no 578.562/BA, Pleno, Rel. Min. EROS GRAU, DJe 11.09.2008.

${ }^{236} \mathrm{O}$ julgamento foi suspenso por pedido de vista do Min. CELSO DE MELLO. Recentemente, foi protocolado pedido de desistência do recurso.
} 
efetivamente vinculados a entidades religiosas. Com efeito, a imunidade não pode beneficiar as empresas privadas que exploram cemitérios com o objetivo de perseguir fins lucrativos, uma vez que, nesses casos, não há que se falar em proteção à liberdade de crença e de culto. Ademais, tais empreendimentos ostentam nítida capacidade contributiva, ao contrário das atividades religiosas, que, como ressaltado acima, estão fora do domínio econômico.

Por sua vez, a expressão “de qualquer culto” empregada pela Constituição Federal indica que estarão protegidos pela imunidade tributária todo e qualquer tipo de manifestação religiosa. Aliás, essa é também a interpretação que mais se coaduna como o princípio da liberdade religiosa, com o caráter laico do Estado brasileiro e com a proibição de subvenção aos cultos, visto que todos eles determinam que o Estado proteja igualmente as diferentes manifestações religiosas, sem que possa ser dada preferência a qualquer uma delas.

No mesmo sentido o magistério de RICARDO LOBO TORRES, para quem o conceito de religião é aberto, protegendo todo e qualquer culto religioso. Salienta que o intérprete deve buscar o sentido mais amplo possível para a expressão, de modo a não prejudicar as crenças das minorias. Assim, afirma o autor que o conceito de religião deve ser funcional: basta que as pessoas se reúnam livremente para a prática do culto e se sintam moralmente obrigadas pelos princípios dele emanados, para que ele esteja abrangido pela imunidade tributária ${ }^{237}{ }^{238}$.

237 TORRES, Ricardo Lobo. Tratado de Direito Constitucional Financeiro e Tributário, p. 253.

${ }^{238}$ Quanto a essa matéria, vale mencionar recente decisão proferida pelo STF, nos autos do RE $\mathrm{n}^{\mathrm{o}} 562.351 / \mathrm{RS}\left(1^{\mathrm{a}}\right.$ Turma, DJe 13.12.2012), na qual prevaleceu o entendimento de que a imunidade tributária conferida pelo art. 150, VI, "b”, da Constituição não alcançaria a maçonaria, por não se tratar de uma verdadeira religião. 


\title{
5.4. As Imunidades dos Partidos Políticos, das Entidades Sindicais dos Trabalhadores e das Instituições de Educação e Assistência Social.
}

\subsubsection{Origem e função das imunidades.}

A Constituição consagra, no art. 150, VI, alínea "c", as imunidades relativas ao patrimônio, à renda e aos serviços dos partidos políticos, das entidades sindicais dos trabalhadores e das instituições de educação e de assistência social, sem fins lucrativos.

A imunidade dos partidos políticos, incluindo suas fundações, e das entidades sindicais dos trabalhadores volta-se à proteção da liberdade de associação profissional e sindical $\left(\operatorname{art.} 8^{\circ}\right.$ ) e da livre criação e extinção de partidos políticos (art. 17), indispensável ao pleno funcionamento da democracia brasileira, pautada no pluripartidarismo.

Por sua vez, a imunidade das instituições de assistência social e de educação, sem fins lucrativos, fundamenta-se em seu caráter de entidades non profits e no fato de que realizam funções que, a princípio, deveriam ser desenvolvidas pelo próprio Estado.

\section{Como ensina RuY BARBosA NogUeIRA ${ }^{239}$ :}

\begin{abstract}
Como é notório e já salientou, no início deste século, o então maior tributarista dos EE.UU., SELIGMAN - após esclarecer a origem da palavra "IMMUNITAS" - seria um dos maiores absurdos que as entidades de caridade, científicas ou de educação, sem fins lucrativos, fossem obrigadas a pagar impostos ao tesouro público, quando todo o seu patrimônio, rendas ou serviços já são destinados a preencher tais funções ou atribuições essenciais do Estado (cfr. Edwin R.A. Seligman, L'Impôt sur le revenu, tradução de William Qualid, Paris, 1913, págs. 26 a 31).

$[\ldots]$

É mesmo um truísmo universal, referido por Günter Schmölders em sua clássica obra Teoria geral do imposto, que "Wo nichts ist, hat selbst der Kaiser sein Recht verloren"- Onde nada existe até o soberano perdeu seu direito ao imposto (vide Allgemeine Steuerlehre, $4^{\mathrm{a}}$ edição de 1965, Duncker \& Humblot, Berlim, pág. 94).
\end{abstract}

De fato, considerando que essas instituições já despendem todos os seus recursos na prestação de serviços públicos, cuja responsabilidade havia sido atribuída inicialmente ao Estado, elas não ostentam capacidade contributiva para arcar com o pagamento de impostos. 


\subsubsection{Abrangência das imunidades.}

Se, de um lado, não há muito debate sobre a imunidade dos partidos políticos e das entidades sindicais de trabalhadores, de outro, a situação é particularmente problemática quando se trata de aplicar a imunidade das instituições de educação e de assistência social.

Isso porque, nas últimas décadas, tais entidades têm passado por um intenso processo de profissionalização, tornando-se cada vez mais complexas. Nesse contexto, muitas delas passaram a cobrar por alguns dos serviços prestados à população, com objetivo de gerar receitas para o custeamento dos seus serviços e tornarem-se assim autossustentáveis.

Diante disso, passou-se a questionar se a imunidade tributária das instituições de assistência social e de educação possuiria como requisito a gratuidade, isto é, se estaria vedado a tais entidades a cobrança de qualquer pagamento pela prestação de seus serviços.

Como visto acima, a Constituição Federal e o CTN determinam que essas instituições não poderão distribuir qualquer parcela do seu patrimônio ou da sua renda aos particulares. Assim, não vedaram a obtenção de lucro por tais entidades. Antes o pressupõem.

Desse modo, são requisitos para o reconhecimento da imunidade que tais entidades não tenham finalidade lucrativa e desenvolvam atividades essenciais ao Estado, que são de interesse público. Logo, não há o requisito da gratuidade, sendo possível cobrar pelos serviços prestados àqueles que puderem pagar e oferecê-los gratuitamente aos necessitados.

Para alguns autores, isso vale, inclusive, para as entidades beneficentes de assistência social, às quais se aplica a imunidade às contribuições para a Seguridade Social prevista no art. $195, \S 7^{\circ}$. É o que aduzem Aires F. BARRETo e PAUlo Ayres BARRETO ${ }^{240}$ :

[...] instituição de assistência social é aquela cujo objeto social, descrito no respectivo estatuto, envolve um ou mais dos fins públicos referidos pela Constituição, isto é, o de colaborar com o Estado na realização de uma obra social para a coletividade.

Mais que entidade de assistência social, tem ela que ser beneficente. Este vocábulo tem por fim deixar patente que a instituição deve assistir carentes e necessitados, provendo uma ou algumas de suas (destes) necessidades (assistência médica, odontológica, jurídica). Ter atuação que vise à proteção da família ou amparo à velhice, a crianças e a adolescentes carentes. Colaborar com o Estado em outros campos, seja promovendo a integração de pessoas ao mercado de trabalho, seja viabilizando a habilitação e a reabilitação das pessoas portadoras de deficiência, seja proporcionando sua integração à vida comunitária. (...)

É instituição de assistência social a que dedicar-se a um ou alguns desses misteres. E é beneficente aquela que dedicar parte dessas atividades ao atendimento gratuito de carentes e de desvalidos. (...)

Não é necessário que a gratuidade envolva grandes percentuais. É sabido que para prover a necessidade de uns poucos é necessário contar com os recursos de muitos. Qualquer que

240 BARRETO, Aires Fernandino e BARRETO, Paulo Ayres. Imunidades Tributárias: Limitações Constitucionais ao Poder de Tributar, pp. 108-111. 
seja esse percentual, exceto se absolutamente ínfimo, insignificante, há o caráter beneficente. Aliás, pequeno que seja esse percentual, será sempre um auxílio ao Estado, em missões que lhe competem.

(...) é despropositado pretender que os serviços prestados por instituições de educação e de assistência social sejam sempre gratuitos. Esse despropósito fica mais visível se tomarmos em conta fato singelo: se os serviços prestados por essas instituições fossem (sempre) todos gratuitos de nada valeria a imunidade. Fossem gratuitos, não teriam preço; não tivessem preço, jamais poderiam ser objeto de tributação por via de impostos, porque não haveria qualquer manifestação de capacidade contributiva, pressuposto inafastável da incidência de todo e qualquer imposto.

Todo mundo sabe, ninguém desconhece. Atividades graciosas, gratuitas, não podem ser objeto de tributação, por via de imposto. Não há conteúdo econômico nessas atividades, logo, não podem ser alvo de imposto. Nem mesmo de contribuições porque estas envolvem caracteres de impostos (...).

Conseqüência inexorável é que a imunidade se volte exatamente para os serviços não gratuitos, para os serviços cobrados. Só estes têm preço. Só estes podem formar renda, cuja distribuição é vedada. É de uma obviedade gritante: só tem sentido haver imunidade para serviços em que há preço.

Assim também já se manifestou o STF, o qual reconheceu que a imunidade do art. 150, VI, “c”, não pode ser afastada pela circunstância de as instituições de educação cobrarem pela prestação dos seus serviços, desde que respeitados os requisitos do art. 14 do $\mathrm{CTN}^{241}$.

Também foi questionado se a imunidade em comento teria como requisito a universalidade, é dizer, se, para fazer jus à desoneração tributária, as entidades teriam que ofertar seus serviços a toda a população ou se poderiam oferecê-los a um público limitado.

A situação era particularmente problemática no que toca às instituições de assistência social, tendo em vista a proliferação das entidades fechadas de previdência privada, que buscavam fazer jus à desoneração, mas atendiam apenas um público específico.

Após muitas oscilações, o STF consolidou o entendimento de que a universalidade não era necessária, reconhecendo assim a imunidade tributária das entidades fechadas de previdência privada, desde que não houvesse contribuição dos beneficiários ${ }^{242}$.

Vale ressaltar que, para essa hipótese, foi exigida uma gratuidade relativa, isto é, que os benefícios sejam custeados pelo empregador e não pelos próprios beneficiários ${ }^{243}$.

\footnotetext{
${ }^{241}$ Trata-se de entendimento consolidado no STF há muitas décadas, conforme acórdãos proferidos no RE ${ }^{\circ}$ 93.463/RJ, $2^{\text {a }}$ Turma, Rel. Min. CORDEIRO GUERRA, DJ 14.05.1982, e no RE 58.691/SP, $1^{\text {a }}$ Turma, Rel. Min. EVANDRO LINS, DJ 14.09.1966.

${ }^{242}$ Esse entendimento foi consolidado através da Súmula 730, que assim estabelece: "A imunidade tributária conferida a instituições de assistência social sem fins lucrativos pelo art. 150, VI, 'c', da Constituição somente alcança as entidades fechadas de previdência social privada se não houver contribuição dos beneficiários".

${ }^{243}$ Como leciona MISABEL DERZI, com isso o STF definiu o conceito de instituições de assistência social, estabelecendo que, para fazer jus à imunidade, é necessário que os benefícios sejam concedidos em favor dos necessitados e, portanto, gratuitamente, ainda que a instituição tenha de cobrar de alguns para custeá-los. Desse modo, foi afastado o requisito da gratuidade total, exigindo-se apenas a gratuidade relativa (in Limitações Constitucionais ao Poder de Tributar, nota de atualização, p. 556).
} 


\subsection{Interpretação do Art. 150, $\$^{\circ}$, da Constituição.}

Estabelece o $\S 4^{\circ}$ do art. 150 da Constituição de 1988 que as imunidades previstas nas alíneas "b" e "c" desse dispositivo compreendem somente o patrimônio, a renda e os serviços relacionados com as finalidades essenciais das entidades nelas mencionadas.

Essa previsão traz à tona uma importante discussão acerca da abrangência de tais imunidades tributárias, é dizer, se a desoneração pode alcançar apenas as atividades religiosas, no que se refere à alínea "b", e os serviços educacionais e assistenciais, no que tange à alínea “c”, ou se pode alcançar também atividades econômicas realizadas por essas entidades.

Antes mesmo da edição da Constituição de 1988, essa questão já gerava controvérsias na jurisprudência, sendo exemplo disso o acórdão proferido pelo STF no RE $n^{\circ}$ $116.188 / \mathrm{SP}^{244}$. No caso, discutia-se sobre a possibilidade de tributar a prestação de serviços de diversão pública realizados pelo Serviço Social do Comércio - SESC, quando houvesse cobrança de ingressos dos comerciários e do público em geral. Na ocasião, o Relator do caso, Ministro OCTAVIo GALLOTTI, votou pela incidência do tributo, dado que o SESC desenvolvia atividade similar a de empresa prestadora de serviços, fazendo concorrência com as empresas privadas. Logo, considerando que o intento do Texto Constitucional não era o de privilegiar a entidade assistencial no mercado, a imunidade ao ISS não poderia ser reconhecida.

$\mathrm{Na}$ ocasião, o Ministro ressaltou a distinção entre os serviços prestados exclusivamente aos associados e os serviços prestados ao público em geral, afirmando que a imunidade aplicar-se-ia apenas no primeiro caso. Ademais, alegou que haveria intuito lucrativo e habitualidade na prestação dos serviços de diversão pública por parte do SESC.

Entretanto, prevaleceu o entendimento do Ministro SYDNEY SANCHES, para quem a imunidade teria buscado evitar encargos tributários que pudessem sacrificar o exercício das finalidades das instituições assistenciais, preservando assim sua receita, de qualquer natureza, incluindo aquela obtida mediante a cobrança por serviços prestados, como os de diversão pública. Assim, se a receita fosse sujeita ao ISS, ela estaria consideravelmente reduzida, em detrimento dos objetivos da entidade. Ademais, ao tributá-las, o Poder Público estaria obtendo proveito com o exercício de atividade que caberia a ele prestar, em primeiro lugar. Concluiu desse modo que, considerando que as rendas obtidas pelo SESC com a prestação dos serviços seriam aproveitadas em suas finalidades assistenciais, a imunidade deveria ser aplicada.

${ }^{244} \mathrm{RE} \mathrm{n}^{\mathrm{o}} 116.188 / \mathrm{SP}, 1^{\mathrm{a}}$ Turma, Relator p/ acórdão Min. SYDNEY SANCHES, DJ 16.03.1990. 
Esse entendimento foi confirmado posteriormente no julgamento do AI $\mathrm{n}^{\circ}$ 155.822 AgR/SP ${ }^{245}$, já na vigência da Constituição de 1988, que reconheceu novamente a imunidade dos serviços de diversão pública prestados pelo SESC, sempre com fundamento no fato de que as receitas obtidas seriam depois destinadas às suas finalidades assistenciais.

A interpretação do art. $150, \S 4^{\circ}$, da Constituição também levou o STF a entender que a renda obtida pela instituição de assistência social mediante cobrança de estacionamento de veículos em área interna da entidade, destinada ao custeio de suas atividades, estaria abrangida pela imunidade, aplicando-se o precedente firmado no $\mathrm{RE} \mathrm{n}^{\mathrm{o}} 116.188 / \mathrm{SP}^{246}$.

A jurisprudência do STF também passou a reconhecer a imunidade das instituições assistenciais no que diz respeito ao IPTU incidente sobre imóveis locados a terceiros, sempre que a renda dos aluguéis fosse aplicada em suas finalidades essenciais.

Esse entendimento já havia sido adotado no julgamento do $\mathrm{RE} \mathrm{n}^{\mathrm{o}}$ 97.708/ $\mathrm{MG}^{247} \mathrm{e}$ foi reiterado em diversos julgados como o $\mathrm{RE} \mathrm{n}^{\mathrm{o}} 257.700 / \mathrm{MG}^{248}$ e o $\mathrm{RE} \mathrm{n}^{\mathrm{o}} 237.718 / \mathrm{SP}^{249}$. No último caso, ressaltou o relator que a imunidade em tela deveria ser interpretada teleologicamente, de modo a maximizar a sua efetividade, como garantia de concretização dos valores constitucionais que inspiraram a sua instituição pelo Texto Constitucional.

Adotou-se a posição de LUCIANO AMARO, para quem a norma constitucional, quando se refere às rendas relacionadas às finalidades essenciais, diz respeito à destinação das rendas e não à natureza destas. Desse modo, independentemente da natureza da renda, sendo ela destinada ao atendimento da finalidade essencial da entidade, a imunidade deveria ser reconhecida. Para LUCIANO AMARO "seria um dislate supor que 'rendas relacionadas com as finalidades essenciais' pudesse significar, restritivamente, rendas produzidas pelo objeto social da entidade. Freqüentemente, o atendimento do objeto social é motivo para despesa e não fonte de recursos. Fosse aquele o sentido, qualquer fonte de custeio da entidade que não derivasse dos próprios usuários de seus serviços ficaria fora do alcance da imunidade" 250 .

No entanto, já naquela ocasião, ressaltou o Relator a distinção entre a imunidade dos templos e a imunidade das instituições de educação e de assistência social no que diz respeito à tributação de imóveis locados. Relembrou-se a opinião de AlIOMAR BALEEIRO,

\footnotetext{
${ }^{245} \mathrm{AI} \mathrm{n}^{\mathrm{o}}$ 155.822 AgR/SP, $1^{\text {a }}$ Turma, Relator Min. ILMAR GALVÃO, DJ 02.06.1995.

${ }^{246} \mathrm{RE} \mathrm{n}^{\mathrm{o}}$ 144.900/SP, $1^{\mathrm{a}}$ Turma, Relator Min. ILMAR GALVÃO, DJ 26.09.1997.

${ }^{247} \mathrm{RE} \mathrm{n}^{\circ}$ 97.708/MG, $2^{\mathrm{a}}$ Turma, Relator Min. ALDIR PASSARINHO, DJ 22.06.1984.

${ }^{248} \mathrm{RE} \mathrm{n}^{\circ}$ 257.700/MG, $1^{\mathrm{a}}$ Turma, Relator Min. ILMAR GALVÃO, DJ 29.09.2000.

${ }^{249} \mathrm{RE} \mathrm{n}^{\mathrm{o}}$ 237.718/SP, Pleno, Relator Min. SEPÚLVEDA PERTENCE, DJ 06.09.2001.

${ }^{250}$ AMARO, Luciano. Algumas Questões sobre a Imunidade Tributária. In: MARTINS, Ives Gandra da Silva (coord.). Imunidades Tributárias, pp. 143-151.
} 
para quem não seriam imunes ao IPTU as casas de aluguel de propriedade das organizações religiosas, tendo em vista que o Estado não pode subvencionar cultos.

Para o Ministro SePúlveda Pertence, o entendimento de BAlEeIro estaria correto, uma vez que a imunidade dos templos visa apenas assegurar e não embaraçar a liberdade de culto, de modo que ela não poderia funcionar como subsídio ou incentivo às manifestações religiosas. Diferente, afirma, é a inspiração da imunidade das instituições de educação e assistência social, em relação às quais a imunidade não atua apenas como garantia de sua licitude, mas como "norma de estímulo, de direito promocional, de sanção premial a atividades privadas de interesse público que suprem as impotências do Estado”.

A imunidade ao IPTU dos imóveis de propriedade de instituições de educação e assistência social, quando locados a terceiros, foi reconhecida em diversos outros casos, como o RE n ${ }^{\circ} 241.150 / \mathrm{SP}^{251}$ e o RE n ${ }^{\mathrm{o}} 210.742 / \mathrm{MG}^{252}$, dando origem à Súmula no $724^{253}$.

Por sua vez, na ocasião do julgamento do RE $\mathrm{n}^{\mathrm{o}} 325.822 / \mathrm{SP}^{254}$, o Supremo entendeu, por maioria, que a imunidade também seria aplicável aos imóveis alugados de instituições religiosas. No entanto, a questão era controversa naquele Tribunal, tendo sido suscitados diversos argumentos a favor e contra a aplicação da desoneração tributária.

Na ocasião, argumentou o Ministro GILMAR MENDES que o art. 150, $\S 4^{\circ}$, teria feito uma equiparação entre as letras "b" e "c" do dispositivo constitucional, de modo que a imunidade alcançaria o patrimônio, a renda e os serviços dos templos de qualquer culto.

Mencionou o argumento trazido por IVES GANDRA DA SILVA MARTINS ${ }^{255}$, para quem a imunidade não poderia ser aplicada às atividades que fossem idênticas ou análogas àquelas desenvolvidas por empresas privadas. Logo, se uma entidade imune alugasse seu imóvel, tal locação não constituiria atividade econômica desvinculada de seu objetivo e também não feriria o mercado, não cabendo a cobrança do IPTU. Por outro lado, caso a mesma entidade, para obter recursos para suas finalidades, decidisse montar uma fábrica de sapatos, a nova atividade, embora indiretamente referenciada, não seria imune, vez que poderia ensejar a dominação do mercado ou a eliminação da concorrência, gerando lucros não

\footnotetext{
${ }^{251} \mathrm{RE} \mathrm{n}^{\mathrm{o}}$ 241.150/SP, $1^{\text {a }}$ Turma, Relator Min. MOREIRA ALVES, DJ 10.08.2001.

${ }^{252} \mathrm{RE} \mathrm{n}^{\circ}$ 210.742/MG, $1^{\text {a }}$ Turma, Relator Min. MOREIRA ALVES, DJ 14.12.2001. No mesmo sentido os seguintes julgados: AI no 438.889 AgR/MG, $2^{\mathrm{a}}$ Turma, Relator Min. CARLOS VELLOSO, DJ 27.02.2004; e AI $\mathrm{n}^{\circ}$ 501.686 AgR/MG, $1^{\text {a }}$ Turma, Relator Min. EROS GRAU, DJ 08.04.2005, dentre outros.

${ }^{253}$ Súmula $\mathrm{n}^{\circ}$ 724: "Ainda quando alugado a terceiros, permanece imune ao IPTU o imóvel pertencente a qualquer das entidades referidas pelo art. 150, VI, "c" da Constituição, desde que o valor dos aluguéis seja aplicado nas atividades essenciais de tais entidades".

${ }^{254} \mathrm{RE} \mathrm{n}^{\circ}$ 325.822/SP, Pleno, Relator p/ acórdão Min. GILMAR MENDES, DJ 14.05.2004.

${ }^{255}$ MARTINS, Ives Gandra da Silva. Imunidades Tributárias. In: MARTINS, Ives Gandra da Silva (coord.). Imunidades Tributárias, pp. 45-46.
} 
tributáveis exagerados quando comparados aos lucros auferidos pelos concorrentes, não beneficiados pela imunidade.

Considerando que, naquele caso concreto, tratava-se de imóvel locado a terceiros, entendeu então o Ministro que a imunidade seria aplicável, em linha com o entendimento desenvolvido pelo Tribunal no que tange às instituições assistenciais e educacionais.

O Ministro Nelson Jobim acompanhou GiLmar Mendes, argumentando que o art. 150, $4^{\circ}$, estabeleceu a trilogia patrimônio-renda-serviços relacionados também à finalidade religiosa. No mesmo sentido manifestaram-se os Ministros MoreIRA Alves e MARCO AURÉLIO, sob o argumento de que os bens estariam destinados à finalidade do templo, tendo em vista que a renda obtida com a locação seria aplicada em fins religiosos.

Em sentido contrário manifestou-se o Ministro IlMAR GALVÃO, para quem seria extremamente difícil identificar no conceito de "templos de qualquer culto" lotes vagos e prédios comerciais dados em locação. Assim, a imunidade poderia ser aplicada apenas aos recintos de culto ou seus anexos (casas paroquiais, sedes de congregações religiosas e outras dependências institucionais dos cultos), mas não às casas para locação, aos terrenos aforados e a outros bens não destinados a práticas religiosas, mesmo que pertencentes à administração de seitas ou cultos.

Quanto ao $\S 4^{\circ}$, afirmou o Ministro que o dispositivo deveria ser aplicado à alínea "b" no que coubesse, isto é, no sentido de que a imunidade deveria compreender também as rendas resultantes das contribuições dos fiéis e a remuneração eventualmente cobrada por serviços religiosos a estes prestados, já que relacionados com as finalidades do culto. Não poderia, portanto, ser estendida a imóveis locados, vez que desvinculados do culto.

O mesmo entendimento foi seguido pelo Ministro CARLos Velloso.

A tributação também foi defendida pela Ministra ELLEN GRACIE e pelo Ministro SEPÚlVEDA PERTENCE, para quem o princípio da separação entre Estado e Igreja não permitiria estender a imunidade para tais atividades. Argumentou SEPÚlveda PeRTENCE que as imunidades das alíneas "b" e "c" seriam distintas, eis que as instituições de educação e de assistência social desenvolvem atividades que o Estado deseja estimular, ao passo que os templos desenvolvem atividades que o Estado não pode estimular, mas apenas tolerar.

Concluiu que "todo favor dado, portanto, a instituições religiosas há de estar intrinsecamente ligado e, consequentemente, adstrito, ao valor constitucional que se visa a proteger, a liberdade de culto" e que, justamente pela diferença existente entre tais imunidades, a Constituição não teria reunido em um só inciso as instituições de assistência e 
educação e as entidades religiosas. Assim, considerando a necessidade de interpretar o art. $150, \S 4^{\circ}$, de acordo com a regra da laicidade do estatuto republicano, entendeu SEPÚlvEDA PERTENCE que a imunidade não poderia ser estendida aos imóveis voltados à locação.

No que diz respeito ao ICM e ao ICMS, o entendimento inicial do STF era desfavorável à imunidade nas hipóteses em que a entidade comercializasse mercadorias ${ }^{256}$.

No entanto, o argumento utilizado não era o de que a desoneração não alcançaria esse tipo de imposto, mas sim o de que o ICM incidente sobre a mercadoria seria arcado pelo consumidor, não onerando a entidade imune. De acordo com o Ministro AlIOMAR BALEEIRO, o ICM presumir-se-ia indireto pela sua natureza, repercutindo sobre os consumidores. Assim, caso fosse reconhecida a imunidade, ela acabaria por beneficiar os particulares, e não a instituição de assistência social. No entanto, salientou o Ministro que, na situação inversa, isto é, da entidade imune que adquirisse mercadorias, a desoneração deveria ser reconhecida.

A imunidade tributária também foi afastada pelo Supremo no que diz respeito ao ICM incidente na venda de pães pela Instituição Beneficente Lar de Maria, novamente com base na circunstância da transferência do ônus econômico ao consumidor final ${ }^{257}{ }^{258}$.

Porém, no julgamento do RE $\mathrm{n}^{\mathrm{o}} 210.251 \mathrm{EDv} / \mathrm{SP}^{259}$, houve uma virada jurisprudencial, tendo o STF reconhecido a imunidade na venda de pães pelo Lar de Maria.

Na ocasião, o Ministro SEPúlvedA PERTENCE ressaltou que a jurisprudência do STF não mais reconhecia a imunidade nas hipóteses em que o ente público era o contribuinte de fato, de modo que estar-se-ia adotando critérios distintos em cada uma das situações.

Salientou também o Ministro que a obtenção de vantagens na concorrência se daria em relação a várias outras imunidades, como a do IPTU de imóveis locados, e que tal circunstância não teria sido considerada suficiente para afastar o benefício nesses casos.

Por sua vez, para o Ministro GILMAR MENDES o argumento da transferência do ônus econômico do tributo não seria capaz de afastar a imunidade na espécie. Afirmou que o reconhecimento da imunidade também teria importância jurídico-econômica para o vendedor,

\footnotetext{
${ }^{256} \mathrm{RE} \mathrm{n}^{\circ}$ 75.505/PR, $1^{\text {a }}$ Turma, Relator Min. OSWALDO TRIGUEIRO, DJ 04.04.1973. Esse entendimento foi confirmado posteriormente pela decisão prolatada nos autos do RE $\mathrm{n}^{\circ}$ 81.740/SC (Pleno, Relator Min. XAVIER DE ALBUQUERQUE, DJ 12.12.1975), que afastou a imunidade ao ICM nas vendas feitas pelo SESI.

${ }^{257} \mathrm{RE} \mathrm{n}{ }^{\circ}$ 115.096/SP, $1^{\text {a }}$ Turma, Relator Min. OCTAVIO GALLOTTI, DJ 07.12.1990 e RE ${ }^{\circ}$ 134.573/SP, $1^{\text {a }}$ Turma, Relator Min. MOREIRA ALVES, DJ 29.09.1995. Vale frisar que o acórdão proferido no RE ${ }^{\circ}$ 134.573/SP foi recentemente reformado por decisão monocrática do Min. CELSO DE MELLO (DJe 14.11.2011), que deu provimento ao recurso extraordinário para reconhecer a imunidade no caso.

${ }^{258}$ Também no RE $n^{\circ}$ 164.162/SP (1 ${ }^{\text {a }}$ Turma, Relator Min. ILMAR GALVÃO, DJ 13.09.1996), a imunidade foi afastada relativamente à comercialização de produtos por entidade de assistência social, dado que o ICM e o ICMS, por repercutirem economicamente no consumidor, não atingiriam o patrimônio, nem desfalcariam as rendas, nem reduziriam a eficácia dos serviços prestados por essas entidades. No mesmo sentido o acórdão prolatado nos autos do RE $\mathrm{n}^{\circ}$ 281.433/SP ( $1^{\text {a }}$ Turma, Relator Min. MOREIRA ALVES, DJ 14.12.2001).

${ }^{259} \mathrm{RE} \mathrm{n}^{\circ}$ 210.251 EDv/SP, Pleno, Relator p/ acórdão Min. GILMAR MENDES, DJ 28.11.2003.
} 
para fins de concorrência, aumentando a eficiência dos serviços prestados pela entidade assistencial. Assim, afirmou, uma interpretação teleológica da imunidade tributária conduziria à sua aplicação também à comercialização de produtos pela entidade de assistência.

Esse entendimento foi acompanhado pelo Ministro NELSON JOBIM, para quem o objetivo do constituinte teria sido desonerar as rendas geradas por essas entidades, para que pudessem ser aplicadas em seus fins institucionais. Ademais, não haveria violação à livre concorrência, eis que tais entidades são marginais no processo de mercado. Por fim, alegou que não prosperaria a distinção entre contribuinte de direito e de fato, dado que a transferência do ônus tributário aos consumidores finais não ocorreria em todas as vendas de mercadorias.

Assim, por maioria, o Tribunal reconheceu a imunidade tributária, restando vencida a Ministra Ellen Gracie e os Ministros Celso de Mello e Moreira Alves.

A imunidade ao ICMS foi posteriormente reconhecida em diversos outros julgados daquele Tribunal, tais como o acórdão prolatado no $\mathrm{RE} \mathrm{n}^{\circ} 186.175 \mathrm{ED}-\mathrm{EDv} / \mathrm{SP}^{260} \mathrm{e}$ as decisões monocráticas proferidas no $\mathrm{RE} \mathrm{n}^{\circ}$ 387.406/SP (DJ 11.09.2003), $\mathrm{RE} \mathrm{n}^{\circ}$ 324.199/SP (DJ 07.10.2003), RE $n^{\circ}$ 403.726/SP (DJ 02.12.2003), RE $n^{\circ}$ 295.072/SP (DJ 02.03.2005).

Esse é o entendimento que ainda prevalece naquele Tribunal, que tem reconhecido indistintamente a imunidade das entidades religiosas e das instituições de educação e assistência mesmo quando realizam atividades econômicas, tais como o aluguel de imóveis e a comercialização de mercadorias, desde que comprovado que as rendas obtidas com essas atividades são destinadas integralmente à realização das suas finalidades essenciais ${ }^{261}$.

Frise-se que, na grande maioria dos casos, não é feita qualquer análise das circunstâncias do caso concreto, da magnitude das atividades desenvolvidas pelas entidades imunes e dos seus possíveis impactos na livre concorrência. Assim, todos os requisitos hoje impostos pelo STF para reconhecer a imunidade recíproca nas atividades econômicas são ignorados quando se trata de examinar as imunidades das alíneas "b" e "c" do art. 150, VI"262.

Tal procedimento é criticável.

Isso porque, mesmo para as entidades de educação e de assistência social, a imunidade não pode ser reconhecida para toda e qualquer atividade econômica, ainda que a renda com ela obtida seja integralmente aplicada nas suas finalidades essenciais. Com efeito,

\footnotetext{
${ }^{260} \mathrm{RE} \mathrm{n}^{\circ}$ 186.175 ED-EDv/SP, Pleno, Rel. Min. ELLEN GRACIE, DJ 17.11.2006.

${ }^{261} \mathrm{AI} \mathrm{n}^{\circ}$ 848.281 AgR/MG, 2 ${ }^{\mathrm{a}}$ Turma, Rel. Min. RICARDO LEWANDOWSKI, DJe 03.10.2011; AI n 746.263 AgR/MG, $1^{\text {a }}$ Turma, Rel. Min. DIAS TOFFOLI, DJe 20.02.2013; ARE no 694.453 AgR/DF, $2^{\text {a }}$ Turma, Rel. Min. RICARDO LEWANDOWSKI, DJe 09.08.2013; ARE n 760.876 AgR/SE, $1^{\text {a }}$ Turma, Rel. Min. DIAS TOFFOLI, DJe 01.04.2014; ARE no 841.212 AgR/RJ, $1^{\text {a }}$ Turma, Rel. Min. LUIZ FUX, DJe 05.12.2014.

${ }^{262}$ É o que também salienta ÁVILA (in Sistema Constitucional Tributário, p. 278).
} 
devem ser reiteradas as observações já feitas quanto à imunidade recíproca, no sentido de que a desoneração não pode gerar desequilíbrios graves na concorrência e no livre mercado.

Assim, a imunidade pode ser aplicada apenas quando as atividades comerciais forem exercidas em caráter apenas marginal e não tiverem o condão de transfigurar a natureza das entidades beneficiadas. O exemplo citado por IVES GANDRA acima é ilustrativo. Isto é, se a pessoa apenas aluga alguns imóveis que estão desocupados com o objetivo de auferir renda, não gerando qualquer prejuízo ao mercado, a imunidade não pode ser afastada. Por outro lado, se a mesma entidade decide instalar uma fábrica ou mesmo decide adquirir dezenas de imóveis e destiná-los à locação em um verdadeiro empreendimento imobiliário, tais atividades não podem ser protegidas pela imunidade, ainda que os recursos obtidos estejam voltados às suas finalidades essenciais, uma vez que nesse caso haveria nítido favorecimento de uma pessoa de Direito Privado em detrimento dos seus concorrentes no livre mercado.

Por sua vez, quanto às entidades religiosas, a imunidade não pode ser reconhecida para qualquer atividade comercial, ainda que os recursos sejam aplicados nos fins do culto.

Com efeito, é necessário distinguir a imunidade dos templos da imunidade das instituições de educação e de assistência social para fins de aplicação do art. $150, \S^{\circ}$.

Isso porque, embora o dispositivo faça referência conjuntamente às imunidades previstas nas alíneas "b" e "c", o fato é que se trata de hipóteses radicalmente distintas de desoneração tributária e que se voltam a proteger princípios e valores também distintos.

A imunidade tributária das entidades de educação e de assistência social volta-se não apenas a proteger tais entidades da tributação, mas também a fomentar suas atividades, tendo em vista que a educação e a assistência social são serviços de interesse público.

Inclusive por essa razão, muitos Estados, ao invés de instituírem imunidades, concedem subvenções a essas entidades, subvenção essa que é expressamente proibida pela Constituição brasileira no que diz respeito às instituições de caráter religioso (art. 19, I).

Assim, desonerar as rendas obtidas com atividades econômicas por instituições de educação e assistência está em conformidade com os objetivos da Constituição, na medida em que estimula a obtenção de receitas por parte dessas entidades para consecução dos seus fins.

Ocorre que tal objetivo não pode ser buscado relativamente às entidades religiosas. A imunidade, nesse caso, não opera como estímulo ou fomento da religião, mas apenas como forma de protegê-la de pressões exercidas pelo Estado através da tributação.

Relembramos aqui as lições de TÉRCIO SAMPAIO FERRAZ JÚNIOR quando trata das funções eficaciais das normas jurídicas. A função da imunidade da alínea "b" é claramente de 
bloqueio da tributação e de resguardo da liberdade religiosa. Já a imunidade das instituições de assistência e de educação exerce não apenas as funções de bloqueio e de resguardo, mas também uma importante função programática, buscando incentivar as suas atividades.

Diante do que foi exposto, a imunidade da alínea "b" deve ser aplicada apenas àquilo que está efetivamente vinculado ao exercício religioso, não tendo o condão de alcançar os prédios alugados a terceiros, as rendas obtidas com a cobrança de estacionamentos ou quaisquer outras atividades econômicas realizadas com o objetivo de gerar receitas.

Diferente será se a entidade religiosa também realizar atividades assistenciais ou educacionais, enquadrando-se na alínea "c". Nesse caso específico, caso as rendas sejam integralmente destinadas a essas finalidades, a imunidade tributária poderá ser reconhecida.

Esse é também o entendimento de SACHA CALMON NAVARRO COÊLHO ${ }^{263}$ :

\begin{abstract}
No que diz respeito ao IPTU, não podem os municípios tributar os prédios ou terrenos onde se exerce o culto (os templos). Podem, a nosso ver, tributar com o predial ou o territorial os terrenos paroquiais, da mitra, das ordens religiosas, das seitas e religiões, que se voltem a fins econômicos: prédios alugados, terrenos arrendados para estacionamento, conventos e seminários, lotes vagos etc. Agora, se o patrimônio imóvel de qualquer religião estiver afetado, ainda que lucrativamente, a fins educacionais ou assistenciais, e desde que estejam sendo devidamente cumpridos os antepostos da lei complementar tributária, há pouco versados, então a questão passa a enquadrar-se nos lindes da imunidade das instituições de educação e assistência, obstando aos municípios o exercício da competência tributária relativamente ao predial e territorial urbano. Mas aí já não se trata da imunidade dos templos de qualquer culto [...].
\end{abstract}

Sendo assim, quanto aos templos de qualquer culto, a imunidade deve ser reconhecida apenas para o patrimônio, as rendas e os serviços estritamente vinculados às atividades religiosas. A desoneração só poderá alcançar atividades econômicas caso o ente em questão seja também uma instituição educacional ou assistencial e os recursos obtidos com os empreendimentos econômicos sejam integralmente destinados a esses fins públicos. Nesse último caso, ainda será necessário verificar os impactos de tais empreendimentos na livre concorrência, de modo a constatar se a imunidade não gerará distorções graves no mercado.

${ }^{263}$ COÊLHO, Sacha Calmon Navarro. Curso de Direito Tributário Brasileiro. $9^{\mathrm{a}}$ ed. Rio de Janeiro: Forense, 2007, p. 304. 
6. As Imunidades dos Livros, Jornais e Periódicos e do Papel Destinado à sua Impressão. 


\subsection{Histórico das Imunidades e sua Função.}

O primeiro texto constitucional brasileiro a consagrar uma das imunidades em tela foi a Constituição de 1946, que dispunha, em seu art. 31, V, “c”, que seria imune à instituição de impostos o papel destinado "exclusivamente à impressão de jornais, periódicos e livros".

Como se pode ver, naquela época, a imunidade alcançava apenas o papel. Posteriormente, na Constituição de 1967, o benefício foi ampliado, passando a contemplar também os livros, jornais e periódicos, conforme dispunha o seu art. 20, III, “d”. Por fim, com a edição da Carta de 1988, tais imunidades tributárias foram mantidas pelo art. 150, VI, "d".

As imunidades em questão voltam-se à realização de diversos princípios constitucionais, tais como a livre manifestação do pensamento, a livre expressão da atividade intelectual, artística, científica e de comunicação (art. 5, IV e IX, da Constituição), a liberdade de aprender, ensinar, pesquisar e divulgar o pensamento, a arte e o saber (art. 206, II), a liberdade de informação jornalística nos veículos de comunicação social, sem qualquer censura de natureza política, ideológica ou artística (art. $220, \S 1^{\circ}$ ), dentre outros direitos.

Em última análise, a instituição das imunidades busca impedir que, através da tributação, possam ser exercidas pressões de cunho político, afigurando-se como elemento imprescindível à realização do Estado Democrático de Direito ${ }^{264}$.

De fato, não se pode ignorar o caráter político e cultural dessas imunidades tributárias. Assim é que, para SACHA CALMON NAVARRO COÊLHO ${ }^{265}$, a instituição do preceito objetiva retirar impostos dos veículos de educação, cultura e saber, de modo a livrá-los de influências políticas. Assim, leciona o autor, a imunidade filia-se aos dispositivos constitucionais que asseguram a liberdade de expressão e opinião e o debate das ideias, em prol da cidadania, do desenvolvimento da cultura, da educação e da informação.

Mas não é só. Para Aliomar BALEeIro, as imunidades possuem duplo objetivo: garantir a liberdade de manifestação do pensamento, o direito de crítica e a propaganda partidária e também amparar e estimular a cultura através dos livros, periódicos e jornais ${ }^{266}$.

É dizer, busca-se não apenas evitar as interferências trazidas pela tributação, mas também facilitar a difusão do conhecimento, ampliando assim o seu acesso pela população.

\footnotetext{
264 Nesse sentido leciona DERZI, Misabel. Limitações Constitucionais ao Poder de Tributar, nota de atualização, pp. 582-583.

${ }^{265}$ COÊLHO, Sacha Calmon Navarro. Curso de Direito Tributário Brasileiro, p. 314.

${ }^{266}$ BALEEIRO, Aliomar. Limitações Constitucionais ao Poder de Tributar, p. 339.
} 
A necessidade de baratear tais produtos a fim de ampliar seu acesso é destacada por diversos autores como um dos principais fundamentos para a criação das imunidades.

Segundo RICARDO LOBO TORRES, o fim precípuo da intributabilidade desses bens é a ideia de justiça fiscal, nela incluída a de utilidade social, consubstanciada na necessidade de baratear o custo dos livros e publicações. Acrescenta o autor que "em país com gravíssima crise de educação e com a necessidade premente de se ampliar o número de pessoas alfabetizadas e instruídas torna-se vital diminuir o custo da produção dos seus instrumentos mais importantes - os livros e os periódicos" ${ }^{267}$. No mesmo sentido o magistério de MANOEL GONÇALVES FERREIRA FILHO ${ }^{268}$, para quem o constituinte procurou baratear o produto final, a fim de facilitar a divulgação das publicações e, por conseguinte, da cultura nacional.

Assim é que a norma do art. 150, VI, “d”, da Constituição tem como função primária a de bloqueio, uma vez que seu primeiro efeito é o de cercear a tributação desses bens. Entretanto, o referido benefício também exerce duas outras funções, a saber: protege as liberdades individuais (função de resguardo) e visa atingir determinados objetivos, como a facilitação da difusão da cultura e do conhecimento (função de programa) ${ }^{269}$.

${ }^{267}$ TORRES, Ricardo Lobo. Tratado de Direito Constitucional Financeiro e Tributário, p. 297.

${ }^{268}$ FERREIRA FILHO, Manoel Gonçalves. Comentários à Constituição Brasileira de 1998. Vol. 3. São Paulo: Saraiva, 1994, p. 104.

${ }^{269}$ No mesmo sentido: FERRAZ JÚNIOR, Tércio Sampaio. Livro Eletrônico e Imunidade Tributária, pp. 33 e ss. 


\subsection{A Imunidade dos Livros, Jornais e Periódicos.}

\subsubsection{Objetos abrangidos pela imunidade.}

A imunidade do art. 150, VI, "d”, da Constituição é classificada pela doutrina como imunidade "objetiva", visto que protege a coisa, isto é, o livro, o jornal, o periódico e o papel destinado à sua impressão, e não a empresa que produz ou comercializa tais objetos.

Bem por isso, entende-se que a imunidade abrange os impostos incidentes sobre a importação, a produção industrial e a circulação de mercadorias, mas não os impostos incidentes sobre a renda e o patrimônio. A jurisprudência do Supremo Tribunal tem se manifestado no mesmo sentido, afastando a desoneração tributária no que diz respeito ao imposto de renda, ao imposto sobre movimentações financeiras ${ }^{270}$ e ao FINSOCIAL ${ }^{271}$.

Quanto aos objetos alcançados pela imunidade, cumpre salientar que a Constituição brasileira empregou termos bastante amplos para instituir a referida desoneração tributária, fazendo referência a "livros", "jornais" e "periódicos". Sendo assim, a imunidade deve compreender "todos os impressos ou gravados, por quaisquer processos tecnológicos, que transmitam aquelas ideias, informações, comentários, narrações reais ou fictícias sobre todos os interesses humanos, por meio de caracteres alfabéticos ou por imagens e, ainda, por signos Braile destinados a cegos", como bem lecionava ALIOMAR BALEEIRO ${ }^{272}$.

Essa também é a interpretação mais consentânea com a função exercida pela imunidade, que deve proteger todos aqueles instrumentos de veiculação do conhecimento.

Não por outro motivo, a doutrina brasileira tem rechaçado restrições ao reconhecimento do benefício tributário em função do conteúdo das publicações. Busca-se, assim, evitar que a tributação se transforme em instrumento de censura, ao sabor das tendências políticas, morais ou religiosas do intérprete. Para MISABEL DERZI ${ }^{273}$ :

Se alguma publicação for atentatória à ética, aos direitos fundamentais do cidadão, ou aos conceitos mais elementares de decência, vigentes na sociedade, cabe aos órgãos públicos competentes retirá-la de circulação. Não tem sentido que os nossos

\footnotetext{
${ }^{270}$ RE no 206.774/RS, $1^{\text {a }}$ Turma, Rel. Min. ILMAR GALVÃO, DJ 29.10.1999; e RE n $^{\text {o }} 504.615$ AgR/SP, $1^{\text {a }}$ Turma, Rel. Min. RICARDO LEWANDOWSKI, DJe 18.05.2011.

${ }^{271} \mathrm{RE} \mathrm{n}^{\mathrm{o}}$ 170.717/PR, $1^{\mathrm{a}}$ Turma, Rel. Min. SEPÚLVEDA PERTENCE, DJ 08.05.1998; AI n 752.233 AgR/SP, $2^{\mathrm{a}}$ Turma, Rel. Min. EROS GRAU, DJe 12.11.2009; RE n⿳0 628.122/SP, Pleno, Rel. Min. GILMAR MENDES, DJe 27.09.2013.

272 BALEEIRO, Aliomar. Limitações Constitucionais ao Poder de Tributar, p. 354.

${ }^{273}$ DERZI, Misabel. Limitações Constitucionais ao Poder de Tributar, nota de atualização, p. 599.
} 
Tribunais passem a analisar cada texto informativo, a fim de verificar se é digno ou não do manto imunitório.

O mesmo entendimento é acolhido por IVEs GANDRA DA SILVA MARTINS ${ }^{274}$. Para esse autor, a imunidade é objetiva, de modo que não interessa o tipo de ideia veiculada pela obra. Afirma que o objetivo da imunidade tributária é justamente evitar a manipulação da opinião pública pelos detentores do poder, de maneira que esta não pode ser utilizada como instrumento para favorecer determinadas publicações em detrimento de outras ${ }^{275}$.

É o que também leciona SACHA CALMon NAVARro CoÊLho, para quem a referência feita pelo constituinte aos objetos imunes foi ampla, não havendo qualquer ressalva quanto ao conteúdo da publicação. Ademais, ressalta o autor, a classificação "moral" das publicações implicaria subjetivismo doutrinário e jurisprudencial, infantilizando a cidadania e delegando aos juízes o papel de verdadeiros censores ${ }^{276}$.

Em linha com essa doutrina, o Supremo Tribunal tem atribuído interpretação ampla ao termo "periódicos", de maneira a abranger, inclusive, as listas telefônicas ${ }^{277}$ e os álbuns de figurinhas ${ }^{278}$. Por outro lado, a imunidade é afastada nas hipóteses de publicações meramente comerciais, como a distribuição de encartes de propaganda ${ }^{279}$.

Uma discussão que ainda provoca controvérsia na doutrina e na jurisprudência diz respeito aos chamados "livros eletrônicos", isto é, livros que não são impressos em papel, mas estão contidos em mídias eletrônicas, tais como CD-ROMs, DVDs, disquetes etc.

Para uma parcela da doutrina, os livros eletrônicos não estariam abrangidos pela imunidade tributária ${ }^{280}$. Argumenta-se que o termo "livro" trazido pela Constituição alcança

\footnotetext{
${ }^{274}$ MARTINS, Ives Gandra da Silva. Imunidade Constitucional de Publicações (Interpretação Teleológica da Norma Maior - Análise Jurisprudencial). Revista de Direito Tributário nº 41, 1987, p. 225.

${ }^{275}$ No mesmo sentido o escólio de GERALDO ATALIBA E AIRES FERNANDINO BARRETO, para quem a Constituição não faz qualquer tipo de restrição ou distinção, considerando incluídos no campo da imunidade todos os tipos de periódicos, de qualquer conteúdo, seja qual for o teor ou a finalidade das informações veiculadas (in Imposto sobre Serviços. Tributação de anúncios e destaques em listas ou guias telefônicos. Inadmissibilidade em face de vedação constitucional, p. 121).

${ }^{276}$ COÊLHO, Sacha Calmon Navarro. Curso de Direito Tributário Brasileiro, p. 315.

${ }^{277} \mathrm{RE} \mathrm{n}^{\circ}$ 101.441/RS, Pleno, Rel. Min. SYDNEY SANCHES, DJ 19.08.1988; AI n ${ }^{\circ} 663.747$ AgR/SP, $2^{\mathrm{a}}$ Turma, Rel. Min. JOAQUIM BARBOSA, DJe 29.04.2010; e ARE $n^{\circ} 778.643$ AgR/ES, $1^{\text {a }}$ Turma, Rel. Min. ROSA WEBER, DJe 31.07.2014.

${ }^{278} \mathrm{RE} \mathrm{n}^{\circ}$ 221.239/SP, $2^{\mathrm{a}}$ Turma, Rel. Min. ELLEN GRACIE, DJ 06.08.2004.

${ }^{279} \mathrm{RE} \mathrm{n}^{\circ}$ 213.094/ES, $1^{\text {a }}$ Turma, Rel. Min. ILMAR GALVÃO, DJ 15.10.1999; ARE no 807.093 ED/MG, $2^{\mathrm{a}}$ Turma, Rel. Min. RICARDO LEWANDOWSKI, DJe 14.08.2014. Como leciona RICARDO LOBO TORRES, excluem-se do conceito de período "as publicações de fins meramente comerciais, de propaganda ou de interesse interno de empresas, sem nenhum objetivo cultural ou político" (in Tratado de Direito Constitucional Financeiro e Tributário, pp. 308-309).

${ }^{280}$ Veja-se nesse sentido, dentre outros, os autores BERNARDO RIBEIRO DE MORAES, RICARDO LOBO TORRES e OSWALDO OTHON DE PONTES SARAIVA FILHO (in MARTINS, Ives Gandra da Silva (coord.). Imunidades Tributárias, pp. 136-137, 204 e 346, respectivamente). No mesmo sentido LUÍS EDUARDO SCHOUERI (in Direito Tributário, p. 404).
} 
apenas os produtos oriundos da cultura tipográfica, é dizer, os produtos impressos em papel. Ademais, afirma-se, a própria Constituição teria feito referência ao livro e ao "papel destinado a sua impressão", limitando assim os objetos imunes àqueles impressos em papel.

Por fim, argumenta-se que, ao tempo da edição da Constituição de 1988, já existiam os livros eletrônicos, de modo que o constituinte poderia ter feito expressa menção a esses objetos, mas não o fez, excluindo-os assim da imunidade tributária. Inclusive, na época em que foi elaborada a Constituição, foi apresentada proposta para incluir no art. 150, VI, os veículos de comunicação audiovisuais, mas tal proposta não foi adotada, o que corroboraria o entendimento de que a intenção do constituinte foi a de excluir esses objetos da desoneração.

Por outro lado, para a parcela hoje majoritária da doutrina brasileira, os livros eletrônicos também fariam jus à imunidade prevista no art. 150, VI, “d”, da Carta ${ }^{281}$.

Primeiramente porque o Texto Constitucional fala apenas em "livro", não estabelecendo qualquer distinção entre os livros impressos em papel e aqueles inseridos em mídias eletrônicas. E no termo "livro" devem ser incluídos todos aqueles instrumentos de veiculação de conhecimento e ideias, independentemente do suporte em que estão fixados.

Sendo assim, não se justifica a restrição da expressão aos produtos oriundos da cultura tipográfica. De fato, livros já havia muito antes da invenção de Gutenberg. Basta pensar nos livros registrados na Antiguidade em tabuletas de argila ou de pedra, nos cilindros de papiro e em pergaminhos. Assim, como ressalta ANDREI PitTEn Velloso: “o livro não é um objeto cultural estático, que se manteve inalterado desde a sua invenção ou que se perenizou na forma em que nos acostumamos a concebê-lo, um volume encadernado, composto por uma sequência de folhas de papel em cujas faces está gravado texto impresso ou manuscrito". Ao contrário, acrescenta o autor, o livro "é fruto de contínuas inovações técnicas dos suportes de leitura, que repercutem na sua forma, estrutura e funcionalidade" 282 .

Outrossim, não é adequado afirmar que a expressão "papel destinado a sua impressão" tenha o condão de limitar o significado dos termos "livros", "jornais" e "periódicos". Na realidade, fala-se em papel destinado à impressão com o intuito de restringir os tipos de papel sujeitos à imunidade, vez que não é todo papel que faz jus à desoneração tributária, mas apenas aqueles utilizados para a impressão de livros, jornais e periódicos.

\footnotetext{
${ }^{281}$ São favoráveis à aplicação da imunidade, dentre outros, os autores IVES GANDRA DA SILVA MARTINS, JOSÉ AUGUSTO DELGADO, DIVA MALERBI, HUGO DE BRITO MACHADO, LUCIANO AMARO, AIRES FERNANDINO BARRETO, JOSÉ EDUARDO SOARES DE MELO e MARCO AURÉLIO GRECO (in MARTINS, Ives Gandra da Silva (coord.). Imunidades Tributárias, pp. 41, 57, 72, 86, 146, 159, 367 e 716 , respectivamente). No mesmo sentido HUMBÉRTO ÁVILA (in Argumentação Jurídica e a Imunidade do Livro Eletrônico, p. 29) e ANDREI PITTEN VELLOSO (in Imunidade Tributária do Livro Digital, pp. 29 e ss.). ${ }^{282}$ VELLOSO, Andrei Pitten. Imunidade Tributária do Livro Digital: Fundamentos e Alcance, p. 21.
} 
Sendo assim, sob a perspectiva do significado linguístico dos termos utilizados, não há qualquer óbice ao reconhecimento da imunidade tributária aos livros eletrônicos.

Ademais, como visto acima, a imunidade da alínea "d" da Constituição tem a função de resguardar a livre manifestação do pensamento, a livre expressão da atividade intelectual, artística, científica e de comunicação, a liberdade de aprender, ensinar, pesquisar e divulgar o pensamento, a arte e o saber, a liberdade de informação jornalística nos veículos de comunicação social, dentre outros direitos expressamente garantidos pela Constituição brasileira. Ora, os livros eletrônicos exercem a mesma função de difusão do conhecimento exercida pelos livros em papel, de modo que o reconhecimento da imunidade no primeiro caso também é a interpretação mais consentânea com o sistema constitucional brasileiro.

Por fim, o argumento de que o legislador de 1988 teria buscado afastar a imunidade em tais casos não pode ser acolhido.

Em primeiro lugar porque é impossível acessar o que pensou o legislador histórico, sendo de ressaltar que a Constituição não é fruto de um legislador isolado, mas sim o resultado de inúmeras vontades, muitas vezes distintas, que colaboram para sua criação.

Assim, como leciona GADAMER, há uma diferença insuperável entre o intérprete e o autor original e é impossível acessar o que pensou o autor na elaboração do texto analisado.

Ademais, ainda que tal acesso fosse possível, não seria desejável, pois o sentido de um texto supera seu autor não apenas ocasionalmente, mas sempre, como aponta GADAMER. Com efeito, a referência ao leitor originário e ao sentido do autor representa um cânon histórico hermenêutico muito rudimentar, que não pode limitar o horizonte de sentido dos textos. O texto, ao se fixar por escrito, desvincula-se da sua origem e de seu autor ${ }^{283}{ }_{-}^{284}$.

Desse modo, ainda que o constituinte de 1988 tenha buscado excluir os livros eletrônicos da imunidade tributária, ele não o fez expressamente, é dizer, tal vontade não foi exteriorizada no texto e, assim, não pode limitar a aplicação do dispositivo constitucional ${ }^{285}$.

Ante o exposto, a desoneração tributária também deve alcançar os livros inseridos em mídias eletrônicas, eis que essa interpretação está alinhada com o sentido linguístico dos termos empregados pela Constituição e, principalmente, é a mais adequada para atingir os

\footnotetext{
${ }^{283}$ Ibidem, p. 512.

${ }^{284}$ É o que também salienta FREDERICK SCHAUER, para quem o recurso à intenção do autor não pode ser visto como necessário, já que a linguagem possui um sentido que é independente daquilo que seus autores originais pretenderam dizer (in Playing by the Rules: A philosophical examination of rule-based decision-making in law and in life. Nova Iorque: Oxford University Press, 2002, p. 219).

${ }^{285}$ Ademais, como aponta IVES GANDRA DA SILVA MARTINS, a sugestão apresentada durante os trabalhos constitucionais para incorporar na imunidade as técnicas audiovisuais não foi propriamente rejeitada. $\mathrm{Na}$ realidade, a rigor, ela não chegou a ser discutida (in Imunidades Tributárias, p. 38).
} 
objetivos visados pela Constituição na instituição desse preceito, voltados à proteção dos veículos de informação e à difusão do conhecimento a toda a população ${ }^{286}$.

\subsubsection{Atividades abrangidas pela imunidade.}

Delimitar os objetos abrangidos pela imunidade relativa aos "livros, jornais e periódicos" não esgota o estudo sobre a interpretação desse preceito. Isso porque, ao fazer referência apenas ao produto acabado, a Constituição brasileira não deixou claro quais atividades estariam alcançadas pela imunidade, eis que esses produtos não são tributáveis em si mesmos, mas apenas no âmbito das relações estabelecidas entre pessoas físicas ou jurídicas.

Diante disso, questiona-se: teria a Constituição imunizado apenas a fase de comercialização dos produtos acabados ou também teriam sido desoneradas todas as etapas do processo produtivo, incluindo a redação, a revisão, a editoração e a impressão das obras?

Essa questão começou a ser discutida no julgamento do RE $\mathrm{n}^{\mathrm{o}}$ 87.049/SP 287 . Naquele caso, questionava-se se os serviços de publicidade prestados por empresas jornalísticas teriam sido alcançados pela imunidade concedida aos livros, jornais e periódicos, tendo em vista a importância dos anúncios para a sobrevivência financeira dessas empresas.

Em seu voto, o Ministro MoreIRA Alves ressaltou a relevância da imunidade para estimular as atividades exercidas pelos veículos de divulgação de ideias, conhecimento e informação. Afirmou que a desoneração destinava-se, diretamente, a reduzir o custo de produção desses produtos. Quanto aos serviços de publicidade, afirmou o então Ministro que:

\footnotetext{
Ora, é notório que os jornais somente podem ser vendidos pelos preços porque o são, em virtude de terem a sua manutenção derivada, precipuamente, da propaganda estampada em suas folhas. Não fora isso, e mister seria o encarecimento sensível de seu preço de venda.

Daí, a razão por que a propaganda divulgada pelos jornais - e isso a par da circunstancia de que não deixa ela de ser uma informação aos leitores - se tornou atividade indispensável a eles. Passou a ser serviço que lhes é ínsito, ao lado da comunicação das notícias e da divulgação de comentários, críticas e trabalhos culturais de toda ordem.

(...)

Se o objetivo da norma constitucional é inequivocamente o de, com um meio de natureza econômica - a imunidade de imposto - facilitar a circulação dos jornais, dentro nele se insere o da imunidade de tributo sobre prestação de serviço que integra a natureza desse veículo de comunicação.
}

\footnotetext{
286 Vale ressaltar que a discussão sobre a imunidade tributária dos livros eletrônicos atualmente encontra-se pendente de julgamento no STF, na sistemática da repercussão geral, nos autos do RE nº 330.817 RG/RJ.

${ }^{287} \mathrm{RE} \mathrm{n}^{\circ}$ 87.049/SP, Pleno, Rel. Min. XAVIER DE ALBUQUERQUE, DJ 01.09.1978.
} 
A importância da imunidade como meio de barateamento dos jornais também foi ressaltada pelo Ministro THOMPSON FLORES, para quem o objetivo da Constituição de facilitar a circulação de jornais e periódicos só seria alcançado reduzindo o seu preço de aquisição. Desse modo, considerando que os anúncios constituem base segura para a redução dos custos e mitigação dos preços, tributá-los não poderia estar na cogitação do preceito constitucional.

A necessidade de barateamento dos livros, jornais e periódicos também foi destacada no julgamento do $\mathrm{RE}^{\mathrm{o}} 101.441 / \mathrm{RS}^{288}$, no qual foi discutida a imunidade das listas telefônicas. Na ocasião, um dos argumentos utilizados pelo Relator foi o de que o propósito da norma constitucional seria inquestionavelmente o de baratear a impressão e divulgação de livros, jornais e periódicos, não se podendo excluir do benefício as listas telefônicas, haja vista sua utilidade social, pois negar a imunidade à lista seria onerar seu custo de produção.

Diante disso, considerando a redação ampla adotada pela Constituição e o propósito de barateamento desses produtos, decidiu o STF no julgamento do RE $\mathrm{n}^{\circ}$ 102.141/RJ que a imunidade dos livros não abrangia apenas a comercialização do produto acabado "mas o conjunto de serviços que o realiza, desde a redação, até a revisão de obra" 289.

O entendimento é acertado, eis que a Constituição fez referência aos livros, jornais e periódicos e tais produtos devem ser protegidos em todas as etapas essenciais ao processo produtivo, desde a sua confecção até a sua comercialização ao consumidor final.

Nesse sentido, o escólio de Aires F. BARreto e PAUlo Ayres BARreto ${ }^{290}$ :

\begin{abstract}
A imunidade do livro e do periódico é "ampla"; é "amplíssima"; "abrange o jornal propriamente dito e todas as atividades e serviços próprios dos mesmos".

Essa a lição expressa do Judiciário, que não tolera quaisquer tentativas tendentes a subtrair a plenitude da eficácia da norma constitucional proibitiva do exercício da competência tributária sobre o livro, o jornal e os demais periódicos. É, com efeito, manifesto que tributar os serviços próprios, indispensáveis, ínsitos ao livro, ao jornal e aos demais periódicos importa onerar esses bens, incorrendo na proibição constitucional. É igualmente manifesto que tributar atividade, sem a qual o livro, o jornal ou outros periódicos não podem chegar às mãos dos leitores, incorre também na vedação constitucional.
\end{abstract}

Esse é também o parecer de Oswaldo Othon de Pontes Saraiva Filho, segundo o qual a imunidade não beneficia apenas o livro, jornal e periódico como produto

\footnotetext{
${ }^{288}$ RE n ${ }^{\circ}$ 101.441/RS, Pleno, Rel. Min. SYDNEY SANCHES, DJ 19.08.1988.

${ }^{289} \mathrm{RE} \mathrm{n}^{\mathrm{o}}$ 102.141/RJ, $2^{\mathrm{a}}$ Turma, Rel. Min. CARLOS MADEIRA, DJ 29.11.1985.

290 BARRETO, Aires Fernandino e BARRETO, Paulo Ayres. Imunidades Tributárias: Limitações Constitucionais ao Poder de Tributar, pp. 87 e 88.
} 
acabado na fase de comercialização, mas envolve todo o processo de produção, incluindo também os serviços de redação, editoração, composição, correção e revisão da obra ${ }^{291}$.

Contudo, posteriormente, quando da apreciação do RE $n^{\circ}$ 230.782/SP, o STF mudou sua posição sobre a matéria, afirmando que não estariam amparados pelo benefício os serviços de composição gráfica necessários à confecção do produto final, tendo em vista que o único insumo expressamente desonerado pela Constituição teria sido o papel de impressão ${ }^{292}$.

Parece-nos, no entanto, que aí houve certa confusão entre a imunidade dos livros, jornais e periódicos e a imunidade do papel, eis que a desoneração dos serviços de composição gráfica, a nosso ver, está contida na primeira imunidade e não na segunda.

Pois bem. Recentemente, o Tribunal mais uma vez se manifestou pela não aplicação da imunidade aos serviços de composição gráfica, no RE n ${ }^{\circ} 434.826 \mathrm{AgR} / \mathrm{MG}^{293}$. A argumentação então adotada, porém, foi diversa, como se constata das passagens dos votos proferidos pelo Relator Ministro CeZAR PELUSO e pelo Ministro JoAQuim BARBOSA.

O Ministro Cezar Peluso traçou um paralelo entre os serviços de publicidade, cuja desoneração já havia sido reconhecida pelo STF, e os serviços de impressão. Argumentou então o Ministro que a imunidade só poderia ser reconhecida quando o serviço fosse essencial à confecção de livros, jornais e periódicos e sua tributação pudesse resultar no impedimento ou em grave embaraço da atividade do contribuinte. Vale conferir o seu voto:

\footnotetext{
(...) quando o serviço é reputado essencial e, de sua tributação possa resultar impedimento ou grave embaraço à atividade do contribuinte, ou, ainda, a extinção mesma de seu modelo de negócio, reconhece-lhe a imunidade. Naquelas raras hipóteses em que a imunidade foi assegurada a algo intangível, como serviço, por exemplo, e não, a algum substrato material, como propaganda em jornais $\left(\operatorname{RE~} \mathrm{n}^{\circ}\right.$ 87.049, Rel. Min. XAVIER DE ALBUQUERQUE, DJ de 01.09.1978, e precedentes análogos), havia razão clara, que advinha do fato de que a tributação de anúncios e publicidade em jornal comprometeria a própria subsistência do modelo econômico por ele comumente adotado. (...)

Assim, quando a Corte proclamou imunidade aos anúncios em jornais e também em listas telefônicas, ponderou a relevância do insumo ou do serviço na estrutura dos custos e na viabilidade econômico-financeira do próprio ramo de negócio de que se tratava, bem como o potencial impacto da tributação no preço dos produtos.
}

\footnotetext{
${ }^{291}$ SARAIVA FILHO, Oswaldo Othon de Pontes. A Imunidade dos Livros, Jornais e Periódicos e do Papel Destinado a sua Impressão. Revista dos Tribunais, Cadernos de Direito Tributário e Finanças Públicas $n^{\circ} 14$, 1996, p. 78. Vale ressaltar que esse autor também defende a aplicação da imunidade a todos os insumos necessários à confecção dos livros, jornais e periódicos, tais como tintas, clichês fotográficos, máquinas e equipamentos, entendimento que não é por nós acolhido, conforme se verá a seguir.

${ }^{292} \mathrm{RE} \mathrm{n}^{\circ}$ 230.782/SP, $1^{\mathrm{a}}$ Turma, Rel. Min. ILMAR GALVÃO, DJ 10.11.2000.

${ }^{293}$ RE no 434.826 AgR/MG, 2a Turma, Rel. p/ acórdão Min. CELSO DE MELLO, DJe 11.12.2013. O mesmo

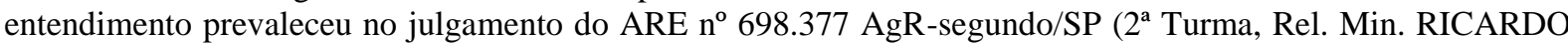
LEWANDOWSKI, DJe 21.08.2014), no qual se afirmou que a imunidade prevista no art. 150, VI, "d", da Constituição não alcançaria as atividades relacionadas à elaboração e à distribuição dos livros, jornais e periódicos, tais como a edição, a impressão, a composição gráfica, a divulgação, a distribuição e o transporte.
} 
Contudo, de acordo com CEZAR PELuso, os serviços de composição gráfica não poderiam ser enquadrados na hipótese citada, tendo em vista que, embora sejam essenciais para a confecção dos produtos, sua tributação não poderia inviabilizar a atividade empresarial.

Veja-se a seguinte passagem do voto do Ministro:

É óbvio que assim o serviço de impressão gráfica ora analisado, como o de composição, considerado necessário nesse procedente, integram o rol daqueles reputados 'indispensáveis à confecção de jornais e periódicos' (fls. 299), sem que daí se siga incidência da norma imunizante, cujo suporte fático (fattispecie abstrata) postula ainda a presença de outra circunstância histórica elementar, que é o perigo de gravosidade ou onerosidade tributária excessiva, incompatível, como tal, com a preservação e o resguardo dos valores jurídicos que a imunidade visa a promover.

(...) Conquanto indiscutivelmente necessário o serviço de impressão gráfica, estou em que, pela modesta influência que apresenta na formação dos custos operacionais da empresa, sua tributação não implica nenhum risco de inviabilidade da relevantíssima atividade de confecção de jornais, como lhe sucederia na hipótese de tributação da publicidade. Atendo-me às expressões do próprio contribuinte, é verdade que a imunização implicaria 'barateamento' dos impressos, mas de modo algum não estaria, na hipótese, a afastar 'providências estatais que possam inviabilizar-lhes a produção' (fls. 299).

E, como, na esteira da jurisprudência da Corte, é imprescindível a cumulação dos critérios da indispensabilidade do serviço e da gravidade de sua tributação, conducente a possibilidade de estorvo ou impedimento da atividade, não encontro razão ao agravante, cuja situação carece do segundo requisito.

Esse ponto também foi salientado pelo Ministro JoAQuim BARBOSA, o qual argumentou que a imunidade tributária alcançava apenas as etapas inerentes à definição do ciclo produtivo de livros, jornais e periódicos. Ressaltou ainda o então Ministro, na linha do voto do Relator, que seria necessário indicar a intensidade do risco que a tributação de determinada atividade realizada por terceiros poderia impor à circulação dessas obras.

A argumentação aqui detalhada é correta, isto é, é necessário que o serviço seja essencial e configure uma etapa inerente à produção de livros, jornais e periódicos, de modo que sua tributação tenha o condão de embaraçar a atividade das empresas desse setor.

Ocorre, porém, que na ocasião aqui tratada o STF pautou-se em premissa falsa quanto aos fatos, vez que a tributação dos serviços de composição gráfica pode inviabilizar a produção de tais obras, especialmente no que diz respeito às empresas de pequeno porte.

Estima-se que atualmente apenas $15 \%$ dos jornais brasileiros possuam gráfica própria, de modo que a grande maioria deve recorrer a terceiros para a impressão de seus 
produtos. Isso se dá especialmente com os jornais locais de pequeno porte, cuja tiragem reduzida torna inviável a internalização das atividades de composição gráfica ${ }^{294}$.

Ademais, os custos de impressão terceirizada representam parcela significativa do custo final do jornal. Calcula-se que correspondam de 35 a $43 \%$ do custo total do produto acabado, ao passo que o custo do papel representa cerca de $40 \%$. Esses percentuais são ainda maiores em empresas de pequeno porte, cujos gastos com mão de obra são reduzidos.

Sendo assim, resta claro que a tributação desses serviços implica aumento substancial dos custos de produção dessas empresas, que recai principalmente sobre jornais locais, podendo resultar na diminuição da tiragem produzida ou mesmo na inviabilização de suas atividades. Desse modo, a negativa da imunidade em tais casos acaba por anular, por via transversa, o fim visado pela Constituição, além de representar uma quebra da neutralidade do benefício, na medida em que favorecerá as empresas economicamente mais fortes.

De fato, as empresas de grande porte não precisam recorrer à impressão terceirizada, tendo em vista que possuem maquinário próprio e assim podem internalizar tais serviços. Logo, são as empresas menores que devem contratar os serviços de composição, arcando não apenas com o seu custo mas também com a margem de lucro da empresa contratada, o que será agravado ainda mais em caso de incidência da exação tributária.

Não se pode esquecer que a imunidade consagrada no art. 150, VI, “d”, da Constituição é um importante instrumento para o desenvolvimento das mídias locais, uma vez que, sem o benefício, muitas dessas empresas não seriam capazes de financiar suas atividades. E a importância da imprensa local para o país é evidente, na medida em que permite a circulação de diferentes ideias, a expressão da cultura local, garantindo dessa forma o pluralismo dos meios de comunicação, em linha com o art. 221, II, do Texto Constitucional.

Por essas razões, a imunidade prevista no art. 150, VI, “d”, da Constituição Federal brasileira não pode alcançar apenas os livros, jornais e periódicos em sua etapa de comercialização, mas deve incluir também todas as fases essenciais à confecção dessas obras.

Essa interpretação, além de autorizada pelo sentido literal do texto constitucional, é aquela que prestigia com mais intensidade a função exercida pela desoneração tributária, bem como outros princípios consagrados pela Constituição, como o pluralismo dos meios de comunicação, evitando assim que a imunidade seja um instrumento para favorecer as empresas economicamente mais fortes em detrimento dos pequenos jornais de opinião.

\footnotetext{
${ }^{294}$ Dados apresentados pela Associação dos Jornais do Interior de Santa Catarina - ADJORI/SC, nos autos do Recurso Extraordinário nº 434.826/MG, em trâmite perante o STF.
} 


\title{
6.3. A Imunidade do Papel Destinado à Impressão.
}

A Constituição consagra não apenas a imunidade dos livros, jornais e periódicos, mas também a imunidade do papel destinado à sua impressão. Como relembra BALEEIRO, a referência expressa feita ao papel possui um fundamento eminentemente político, já que a história é rica em exemplos nos quais o contingenciamento do papel foi utilizado por governos autoritários como forma de sufocar a imprensa livre. Assim, sustentava o autor ${ }^{295}$ :

\begin{abstract}
A Constituição de 1946 introduziu a imunidade do papel de impressão. Duas razões: primeiro, que em 1946 estava muito recente a ditadura de Vargas, que tinha posto colete de ferro na imprensa, não tanto pela violência, prendendo, fechando jornais, mas por meios econômicos. O jornal depende do papel. Então havia a isenção, por lei ordinária, do papel e do material gráfico. Vargas, por meio do papel, também usava o financiamento pelos bancos estatais, e teve uma imprensa passiva, dócil, acomodada, que só dizia o que ele queria. (...) As técnicas de poder pessoal empregadas por Vargas, algumas delas originais. Por exemplo, o papel usado como meio de coação à imprensa. Curioso, na Inglaterra, até 1862, vigorou um imposto com o nome tax on the knowledge, imposto sobre o conhecimento, sobre a informação, e que pesava sobre os jornais. Existia também na Áustria, na Turquia e em outros países. Pesava sobre a quantidade de papel que eles empregavam. (...). Essas as razões da imunidade do papel.
\end{abstract}

Desse modo, através da imunidade, buscava-se evitar que a tributação do papel importado fosse utilizada para abafar a voz do jornalismo independente.

No entanto, BALEEIRO já apontava outra importante função exercida pela imunidade do papel, qual seja, a de baratear o custo final da produção de livros, jornais e periódicos, facilitando assim o seu acesso por toda a população ${ }^{296}$ :

Quando Jorge Amado defendeu essa franquia, na Constituinte de 1946, o interesse cultural ocupou o centro de sua argumentação. $\mathrm{O}$ imposto encarece a matéria-prima do livro, não apenas pela carga fiscal, que se adiciona ao preço, mas também pelos seus efeitos extrafiscais, criando, em certos casos, monopólios em favor do produtor protegido aduaneiramente. Se o papel importado for tributado com intenção protecionista, sempre advogada pelos círculos industriais interessados, o sucedâneo nacional terá seu preço elevado até o nível que lhe permite a eliminação da concorrência pelos meios alfandegários.

Manifesta a incompatibilidade entre o barateamento e democratização dos livros e publicações, como recursos da educação e da cultura dum lado, e os interesses econômicos dos industriais, por outro, a Constituição optou pelos valores espirituais que, ao mesmo tempo, coincidiam com a necessidade de preservar-se a liberdade de crítica e de debate partidário através da imprensa. Estava muito recente a manobra ditatorial de subjugar o jornalismo por meio de contingenciamento do papel importado.

\footnotetext{
295 BALEEIRO, Aliomar. Imunidade e Isenções Tributárias. Revista de Direito Tributário no 1, 1977, p. 79.

${ }^{296}$ BALEEIRO, Aliomar. Limitações Constitucionais ao Poder de Tributar, pp. 577-578.
} 
De fato, a necessidade de barateamento do produto final é uma preocupação que permeia todos os benefícios concedidos pelo art. 150, VI, “d”. Nesse contexto, a importância do reconhecimento expresso da desoneração tributária relativa ao papel é evidente, tendo em vista o peso desse insumo na formação dos preços dos livros, jornais e periódicos.

No entanto, fato é que o papel não é o único insumo utilizado na confecção dessas publicações. Com efeito, nesse processo produtivo são utilizados vários produtos, como tintas e filmes fotográficos, além de máquinas e equipamentos e do imóvel onde é feita a confecção.

Diante disso, passou-se a questionar se o benefício em tela abrangeria apenas o papel ou também os outros insumos e bens do ativo fixo empregados no processo produtivo, já que a desoneração de todas as aquisições em questão poderia reduzir o custo do produto final, contribuindo assim para o fim de barateamento visado pela imunidade tributária.

No julgamento do $\mathrm{RE}^{\mathrm{o}} 174.476 / \mathrm{SP}^{297}$, houve um intenso debate no STF sobre o alcance da expressão "papel destinado a sua impressão".

Para o Ministro IlMAR GALVÃo, o controle exercido pelo governo durante o Estado Novo através da tributação do papel de imprensa explicaria a origem da imunidade do papel destinado à impressão. Ademais, completou o Ministro, se o motivo determinante do benefício fiscal fosse tão somente o barateamento dos livros, jornais e periódicos, teria ele sido estendido aos demais insumos ou teriam sido por ele contemplados os editores.

Por sua vez, o Ministro MARCo AurÉLIo sustentou que o preceito deveria receber interpretação teleológica, de modo a afastar procedimentos que pudessem inibir a produção dessas obras. Com base nisso, concluiu que a parte final do preceito não era exaustiva ou merecedora de interpretação literal, vez que isso redundaria no esvaziamento da regra constitucional. No mesmo sentido manifestaram-se os Ministros CARLOS Velloso e Celso De Mello. Por outro lado, alegou Sepúlveda Pertence que, onde a Constituição se limitou a dizer "papel”, não caberia ao intérprete entender como máquinas, tintas ou imóveis.

Ao final do julgamento, prevaleceu o entendimento de que o benefício constitucional não alcançaria apenas o papel utilizado diretamente na confecção de tais obras, como também insumos nela consumidos, como os filmes e os papéis fotográficos.

Com o passar dos anos, consolidou-se no STF a posição de que a imunidade do art. 150, VI, “d”, não poderia ser aplicada a todos os insumos e bens utilizados no processo produtivo, mas apenas aos insumos assimiláveis ao papel, como os papéis e filmes

${ }^{297} \mathrm{RE} \mathrm{n}^{\mathrm{o}}$ 174.476/SP, Pleno, Rel. p/ acórdão Min. MARCO AURÉLIO, DJ 12.12.1997. 
fotográficos, entendimento que deu origem à Súmula $n^{\circ} 657^{298}$. Desse modo, o benefício foi afastado em relação a diversos outros bens necessários à produção, como tintas para impressão $0^{299}$, equipamentos do parque gráfico e peças de reposição ${ }^{300}$, chapas de gravação ${ }^{301}$, tiras plásticas para amarração de jornais ${ }^{302}$, soluções alcalinas para impressoras ${ }^{303}$, etc.

Recentemente, no entanto, esse panorama foi alterado com o julgamento do $\mathrm{RE}^{\circ}$ 202.149/RS ${ }^{304}$, no qual se afirmou que "a imunidade tributária relativa a livros, jornais e periódicos é ampla, total, apanhando produto, maquinário e insumos" e que "a referência, no preceito, a papel é exemplificativa e não exaustiva".

O argumento utilizado foi o de que as imunidades previstas no art. 150, VI, “d”, devem ter como objetivo facilitar a publicação e, para tanto, devem ser aplicadas não apenas ao produto acabado, como também aos insumos e ao maquinário indispensáveis à produção desses bens. Apenas assim, alegaram os ministros favoráveis à tese, as imunidades seriam potencializadas como instrumento de estímulo à circulação de informações e de cultura.

Esse entendimento também tem recebido acolhida de parte da doutrina.

Nesse sentido o magistério de Hugo DE BRITO MACHADO, para quem a imunidade, para ser efetiva, deveria abranger todo o material necessário à confecção do livro, jornal ou periódico, incluindo todos os insumos empregados na confecção desses produtos e todos os instrumentos ou equipamentos destinados exclusivamente à sua produção ${ }^{305}$.

É o que também sustenta MISABEL DERZI, para quem a referência feita ao papel se justifica por razões históricas e eminentemente políticas e pela sua importância na formação do preço final, mas não seria capaz de restringir o alcance do preceito, que deveria abranger também os insumos, os serviços e os bens do ativo necessários à produção dessas obras.

Para a autora, considerando que a imunidade tem como meta a redução do custo do produto, favorecendo a veiculação de informações, do ensino, da educação e da cultura, ela

\footnotetext{
298 Súmula $n^{\circ}$ 657: “A imunidade prevista no art. 150, VI, 'd', da Constituição federal abrange os filmes e papéis fotográficos necessários à publicação de jornais e periódicos”.

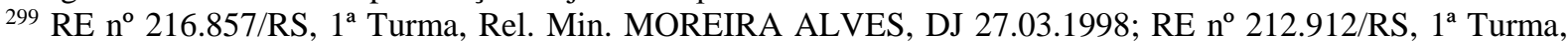
DJ 05.06.1998; AI n 256.315 AgR/RJ, 2 ${ }^{\mathrm{a}}$ Turma, Rel. Min. MARCO AURÉLIO, DJ 20.10.2000; RE $\mathrm{n}^{\circ}$

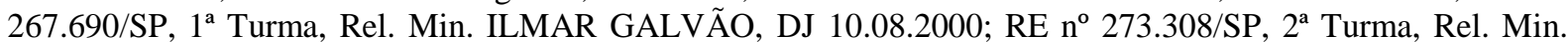
MOREIRA ALVES, DJ 15.09.2000; RE $\mathrm{n}^{\mathrm{o}}$ 265.025/SP, $1^{\mathrm{a}}$ Turma, Rel. Min. MOREIRA ALVES, DJ 21.09.2001; RE no 346.771 AgR/RJ, 2 a Turma, Rel. Min. NELSON JOBIM, DJ 19.12.2002.

${ }^{300}$ RE n $^{\circ}$ 215.798/RS, $1^{\text {a }}$ Turma, Rel. Min. ILMAR GALVÃO, DJ 27.03.1998; e RE n 226.441/RS, $1^{\text {a }}$ Turma, Rel. Min. OCTAVIO GALLOTTI, DJ 21.08.1998.

${ }^{301} \mathrm{RE} \mathrm{n}^{\circ} 244.698 \mathrm{AgR/SP}, 1^{\text {a }}$ Turma, Rel. Min. ELLEN GRACIE, DJ 31.08.2001.

${ }^{302} \mathrm{RE} \mathrm{n}^{\mathrm{o}} 220.154 / \mathrm{RS}, 1^{\mathrm{a}}$ Turma, Rel. Min. OCTAVIO GALLOTTI, DJ 23.10.1998; e RE n ${ }^{\mathrm{o}} 208.638$ AgR/RS, $1^{\mathrm{a}}$ Turma, Rel. Min. SEPÚLVEDA PERTENCE, DJ 30.04.1999.

${ }^{303} \mathrm{RE} \mathrm{n}^{\mathrm{o}}$ 206.076/SP, $1^{\mathrm{a}}$ Turma, Rel. Min. MOREIRA ALVES, DJ 29.05.1998.

${ }^{304} \mathrm{RE} \mathrm{n}^{\circ}$ 202.149/RS, $1^{\mathrm{a}}$ Turma, Rel. p/ acórdão Min. MARCO AURÉLIO, DJe 10.10.2011.

${ }^{305}$ MACHADO, Hugo de Brito. Curso de Direito Tributário, p. 295.
} 
está destinada, em primeiro lugar, a beneficiar o consumidor que sofrerá, pelo mecanismo dos preços, a transferência do encargo financeiro dos impostos incidentes sobre a produção e a comercialização. Desse modo, conclui que o afastamento da imunidade em relação aos insumos não assimiláveis ao papel e aos bens do ativo fixo anularia senão reduziria substancialmente o alcance da imunidade, uma vez que eleva o custo final desses produtos ${ }^{306}$.

Pois bem. Como visto nos capítulos anteriores, um dos principais argumentos a serem levados em consideração na interpretação jurídica é o argumento linguístico, na medida em que ele nos diz quais são os sentidos possíveis dos termos empregados pela Constituição.

O art. 150, VI, “d”, da Carta de 1988 faz referência expressa ao papel destinado à impressão. Assim, estão abrangidos pelo sentido literal possível do texto o papel e os insumos a ele assimiláveis, como os papéis e os filmes fotográficos. Já os demais insumos e os bens do ativo fixo utilizados na confecção de livros, jornais e periódicos não estão abarcados pelo sentido possível do referido preceito. Com efeito, embora nem sempre o sentido possível possa ser encontrado com total nitidez, no caso presente, é evidente que a palavra "papel" não pode designar tintas, máquinas, imóveis ou outros insumos e bens do ativo imobilizado.

Sendo assim, a imunidade para tais casos só poderia ser reconhecida através do recurso à analogia, ao argumento de que esses materiais também são necessários à produção das obras e de que sua tributação poderia encarecer sensivelmente o custo dos produtos finais.

Ocorre que, como salientado nos capítulos anteriores, a analogia e a redução teleológica, por serem hipóteses de desenvolvimento do Direito, não são admissíveis na interpretação das regras que fixam a competência tributária, como as regras de imunidade.

Por essas razões, a imunidade concedida ao papel destinado a impressão pode alcançar apenas o papel empregado na impressão de livros, jornais e periódicos e os insumos a ele assimiláveis. Não pode, portanto, ser aplicada aos demais insumos e bens do ativo fixo, ainda que se comprove que esses produtos são necessários à produção de tais obras.

De fato, seria mesmo desejável que o constituinte houvesse imunizado todos os produtos em tela. No entanto, não foi essa a linha adotada pela Constituição brasileira e o conteúdo dos preceitos nela inseridos não pode ser totalmente ignorado pelo intérprete.

Desse modo, a extensão da imunidade a tais casos não deve ser uma tarefa da interpretação, mas do processo de revisão constitucional, que poderá, este sim, alterar o teor do dispositivo em análise para melhor atender aos princípios albergados pela Constituição.

\footnotetext{
${ }^{306}$ DERZI, Misabel. Limitações Constitucionais ao Poder de Tributar, nota de atualização, pp. 580 e ss.
} 
7. A Imunidade dos Fonogramas e Videofonogramas. 


\subsection{Histórico da Imunidade e sua Função.}

Recentemente, por intermédio da Emenda Constitucional no $75 / 2013$, foi inserida uma nova imunidade tributária no art. 150, VI, da Constituição Federal brasileira.

A nova alínea "e" do referido dispositivo proíbe a instituição de impostos pelos entes da Federação relativamente a "fonogramas e videofonogramas musicais produzidos no Brasil contendo obras musicais ou literomusicais de autores brasileiros e/ou obras em geral interpretadas por artistas brasileiros bem como os suportes materiais ou arquivos digitais que os contenham, salvo na etapa de replicação industrial de mídias ópticas de leitura a laser”.

Por se tratar de uma nova imunidade, que buscou abranger objetos que nunca haviam sido protegidos por meio de desoneração por qualquer Constituição brasileira, é interessante analisar quais foram os objetivos visados pelos legisladores na sua instituição.

Com efeito, embora as finalidades perseguidas pelo legislador histórico não tenham o condão de limitar a interpretação dos preceitos normativos, uma vez que o texto jurídico, após a sua promulgação, desprende-se do seu criador e pode adquirir sentidos que não foram até mesmo por ele pensados, no caso específico ora analisado, por se tratar de um dispositivo que consagra uma imunidade absolutamente inédita, o estudo das motivações que deram origem à sua criação pode oferecer grande auxílio na compreensão deste preceito.

Pois bem. Algumas das razões que motivaram a criação da chamada "imunidade musical" podem ser encontradas na Exposição de Motivos anexa à Proposta de Emenda Constitucional $n^{\circ}$ 123/2011 (que deu origem à $\mathrm{EC} \mathrm{n}^{\mathrm{o}} 75 / 2013$ ) $^{307}$. Vale conferir o seu teor:

A presente proposta de emenda à constituição é, antes de tudo, um brado em defesa da cultura nacional.

É urgente a implantação de medidas que fortaleçam a produção musical brasileira, diante da avalanche cruel de pirataria e da realidade inexorável da rede mundial de computadores (internet).

A proposta de emenda constitucional em apreço cuida de estabelecer imunidade tributária para a produção musical brasileira bem como a comercialização de seus suportes físicos e digitais tendo como única restrição para sua imunidade que estes contenham músicas compostas ou gravadas por autores ou artistas brasileiros, medida que nos parece poder vir a contribuir para reverter o atual quadro de favorecimento da indústria da pirataria, que vemos se solidificar a cada dia em detrimento dos produtos legalmente produzidos e comercializados no País.

(...)

A presente proposta de emenda constitucional pretende interferir nesse quadro retirando de cena um fator que efetivamente torna a concorrência entre o produto pirata e o original quase impraticável: o alto preço dos impostos que recaem sobre

\footnotetext{
${ }^{307}$ Disponível no endereço: http://www.senado.gov.br/atividade/materia/getPDF.asp?t=101280\&tp=1.
} 
esse último, tornando seu custo final muitíssimo maior para o consumidor, independentemente da qualidade técnica, sabidamente muito inferior no produto ilegal, e mesmo do eventual desejo do comprador de prestigiar o trabalho genuíno do artista nacional, o apelo do baixo preço acaba se tornando irresistível, notadamente para aquela faixa da população com poucos recursos, que não pode se dar ao luxo de escolher um produto mais caro quando exista no mercado oferta de outros equivalentes por menor custo.

(...)

Acreditamos que a instituição de imunidade tributária para a produção e a comercialização da música composta e/ou gravada por artistas brasileiros e comercializada em seus diversos suportes, a exemplo do que já ocorre com "livros, jornais, periódicos e o papel destinado a sua impressão", pode atenuar sensivelmente a barreira econômica que pesa sobre o produto original, tornando-o mais acessível ao consumo, popularizando ainda mais seu acesso às classes menos privilegiadas do País, difundindo e consolidando este importante alicerce da cultura brasileira e, por isso mesmo, dando à música a condição de retomar um merecido lugar de destaque na economia nacional.

Como se pode observar, de acordo com a exposição de motivos, a imunidade teria sido inserida na Constituição com o objetivo de: (i) combater a pirataria, na medida em que reduziria o preço dos produtos originais, permitindo que concorressem de forma mais justa com os produtos pirateados; (ii) tornar os produtos originais mais acessíveis para a população, difundindo assim o seu acesso nas classes menos favorecidas; e (iii) promover e consolidar a cultura brasileira, dando à música um lugar de destaque na economia nacional ${ }^{308}$.

Não obstante a relevância dos objetivos expostos pelo legislador, entendemos que a imunidade, tal como instituída, não é o instrumento mais adequado para sua concretização.

Com efeito, a mera redução dos custos dos produtos originais não terá o condão de eliminar a pirataria, tendo em vista que, mesmo reduzido, o preço de mercado de tais produtos ainda será sensivelmente superior àquele dos produtos pirateados. E não poderia ser diferente, uma vez que a carga tributária não é um único elemento que distancia os custos desses produtos. Ao contrário, o produtor de obras originais deve incorrer em inúmeras outras despesas, tais como a contratação de funcionários, o pagamento de direitos autorais, o aluguel ou a aquisição de instalações, as quais não são incorridas pelo produtor da obra pirateada.

Logo, se a imunidade poderá reduzir o custo (e, por via de consequência, o preço) das obras originais, disso não decorre que a pirataria será eliminada ou mesmo reduzida.

Ademais, o combate de atividades ilegais (tal como a reprodução desautorizada de obras musicais) depende também de operações de fiscalização por parte do Estado e da

\footnotetext{
${ }^{308}$ Esses objetivos também são apontados por ANDRÉ LUIZ COSTA-CORRÊA (in A (In)constitucionalidade da Emenda Constitucional n. 75: a Imunidade sobre Fonogramas e Videofonogramas e seus Suportes Materiais ou Arquivos Digitais. Revista Dialética de Direito Tributário nº 222, 2014, p. 36).
} 
criação de instrumentos punitivos capazes de prevenir a ocorrência de tais infrações. Assim, a imunidade tributária não se revela o instrumento mais adequado para tal empreitada.

No entanto, de acordo com a exposição de motivos, a desoneração teria sido criada também com o objetivo de tornar tais produtos mais acessíveis à população de baixa renda, difundindo assim a cultura nacional entre as classes menos favorecidas do Brasil.

Este nos parece ser um objetivo legítimo da imunidade tributária e consentâneo com a Constituição Federal brasileira, que, em seu art. 23, V, dispõe que é competência comum da União, dos Estados, do Distrito Federal e dos Municípios "proporcionar os meios de acesso à cultura, à educação e à ciência" e no seu art. 215 dispõe que o Estado "garantirá a todos o pleno exercício dos direitos culturais e acesso às fontes da cultura nacional".

Nesse ponto, inclusive, a desoneração em tela assemelha-se à imunidade prevista na alínea "d" do art. 150, VI, que faz referência aos livros, jornais e periódicos, na medida em que, em ambos os casos, o benefício poderá ensejar o barateamento dos produtos e, assim, atuar como um instrumento para difusão da cultura e do conhecimento a toda a população.

Por outro lado, as imunidades em tela se distinguem, na medida em que o benefício previsto na alínea " $\mathrm{d}$ " foi concedido a todo tipo de livro, jornal ou periódico, independentemente de terem ou não autoria brasileira ou de serem produzidos no país, ao passo que a imunidade prevista na alínea "e" se restringe às obras produzidas no Brasil e que tenham autoria brasileira ou sejam interpretadas por artistas brasileiros.

Inclusive nesse ponto, em que a Constituição faz referência às obras produzidas no território brasileiro, reside o terceiro objetivo citado para a instituição da imunidade: o fortalecimento da indústria nacional voltada à produção de fonogramas e videofonogramas.

Ocorre que a ideia de protecionismo da indústria brasileira tem perdido cada vez mais a sua força em nossa Constituição. A título de exemplo, o art. 171 da Carta de 1988 trazia o conceito de empresa brasileira de capital nacional e previa que a lei poderia conceder a tais entes "proteção e benefícios especiais temporários para desenvolver atividades consideradas estratégicas para a defesa nacional ou imprescindíveis ao desenvolvimento do país”. No entanto, tal dispositivo foi posteriormente revogado pela Emenda Constitucional $n^{\circ}$ 6/1995. Sendo assim, o propósito de fortalecimento da indústria nacional dedicada à produção de música não parece totalmente alinhado com a tendência constitucional hoje presente. 


\subsection{Objetos Abrangidos pela Imunidade.}

Nos termos do art. 150, VI, "e", da Constituição brasileira, a desoneração tributária alcançará os "fonogramas e videofonogramas musicais produzidos no Brasil contendo obras musicais ou literomusicais de autores brasileiros e/ou obras em geral interpretadas por artistas brasileiros bem como os suportes materiais ou arquivos digitais que os contenham, salvo na etapa de replicação industrial de mídias ópticas de leitura a laser”.

Como se vê, o dispositivo constitucional fez uso de diversos termos de natureza técnica, sendo necessário investigar o sentido de cada palavra empregada pelo legislador.

De acordo com o Dicionário Aurélio, fonograma corresponde ao "registro exclusivamente sonoro em suporte material, como disco, fita magnética, etc.”, ao passo que videofonograma designa o "produto da fixação de imagem e som em suporte material (p.ex., o videocassete e o videodisco)" ${ }^{309}$. Já segundo o Dicionário Houaiss, fonograma corresponde à "gravação de uma faixa de disco" e videofonograma designa o "registro de imagens e sons em determinado suporte (como no caso dos videocassetes, videodiscos etc.)"310.

Como se nota, ambos os dicionários relacionam o termo fonograma à fixação ou ao registro exclusivo de sons e o termo videofonograma, ao registro de imagens e sons. A necessidade de um suporte físico para esse registro, por outro lado, não fica totalmente clara.

A utilização dos termos "fonograma" e "videofonograma" não é uma novidade na legislação brasileira. A Lei no 5.988/1973, que inicialmente regulava os direitos autorais, já os empregava para disciplinar essa matéria. De acordo com o art. $4^{\circ}$, incisos VII e VIII, da lei em questão, "fonograma" corresponderia à "fixação, exclusivamente sonora, em suporte material" e "videofonograma" equivaleria à "fixação de imagem e som em suporte material".

Assim, a definição dos termos empregados por este diploma fazia expressa referência a um suporte material, diferenciando-os na medida em que, no primeiro caso, tratar-se-ia de fixação exclusivamente sonora e, no segundo, de fixação de imagem e som.

Posteriormente, a Lei $\mathrm{n}^{\circ} 5.988 / 1973$ foi revogada pela Lei $\mathrm{n}^{\circ}$ 9.610/1998, que atualmente disciplina o tema. Referido diploma também faz uso do termo "fonograma", definindo-o como "toda fixação de sons de uma execução ou interpretação ou de outros sons, ou de uma representação de sons que não seja uma fixação incluída em uma obra

309 FERREIRA, Aurélio Buarque de Holanda. Dicionário Aurélio da Língua Portuguesa. 5 ${ }^{\mathrm{a}}$ ed. Curitiba: Positivo, 2010, pp. 966-967 e 2157.

${ }^{310}$ HOUAISS, Antonio. Dicionário Houaiss da Língua Portuguesa. $1^{\text {a }}$ reimpressão. Rio de Janeiro: Objetiva, 2009, pp. 914 e 1943. 
audiovisual", conforme prescreve o seu art. $5^{\circ}$, inciso IX. Por sua vez, o termo "obra audiovisual" é definido como toda obra que "resulta da fixação de imagens com ou sem som, que tenha a finalidade de criar, por meio de sua reprodução, a impressão de movimento, independentemente dos processos de sua captação, do suporte usado inicial ou posteriormente para fixá-lo, bem como dos meios utilizados para sua veiculação", conforme art. 50, VIII, "i”.

Veja-se que a definição de "fonograma" trazida pela Lei no 9.610/1998 difere daquela prevista pela Lei $n^{\circ} 5.988 / 1973$ no ponto em que deixa de fazer qualquer menção ao suporte físico da obra. A Lei $n^{\circ}$ 9.610/1998, como visto, também é expressa ao estabelecer que o termo "obra audiovisual" deve ser aplicado independentemente do suporte usado.

Essa concepção coaduna-se com o sistema criado pela nova Lei de Direitos Autorais, que em diversos artigos busca desatrelar as obras de seu suporte, material ou imaterial. Assim, prescreve o seu art. $5^{\circ}, \mathrm{XI}$, que produtor é todo aquele que toma a iniciativa e tem a responsabilidade econômica da primeira fixação do fonograma ou da obra audiovisual "qualquer que seja a natureza do suporte utilizado" e prescreve o seu art. $7^{\circ}$ que "são obras intelectuais protegidas as criações do espírito, expressas por qualquer meio ou fixadas em qualquer suporte, tangível ou intangível, conhecido ou que se invente no futuro".

Busca-se assim que todas as obras em questão estejam protegidas pelas normas de Direito Autoral, tendo em vista a multiplicação de novas tecnologias, com a consequente criação de novos meios para fixação e veiculação de ideias, conhecimento e arte.

A Emenda Constitucional no 75/2013 também parece abraçar a mesma ideia, estabelecendo a imunidade dos fonogramas e videofonogramas e dos suportes materiais ou arquivos digitais que os contenham. Assim, foi afastada grande parte da celeuma sobre a aplicação do benefício às obras que não possuem suporte físico, discussão essa que, como vimos no capítulo anterior, tem ocupado o centro do debate sobre a imunidade dos livros.

Desse modo, são imunes à instituição de impostos os fonogramas, entendidos como o registro exclusivamente sonoro, e os videofonogramas, entendidos como o registro de sons e imagens, e os respectivos suportes materiais e os arquivos digitais que os contenham.

Porém, nem todos os fonogramas e videofonogramas musicais estão abrangidos pela imunidade tributária. O art. 150, VI, “e”, da Constituição Federal brasileira exige também que estes sejam produzidos no Brasil e contenham "obras musicais ou literomusicais de autores brasileiros e/ou obras em geral interpretadas por artistas brasileiros". 
Obras musicais são aquelas exclusivamente relativas a música, ao passo que as obras literomusicais são aquelas que agregam música e também literatura ${ }^{311}$.

O dispositivo constitucional também faz referência a "obras em geral”, o que pode conduzir ao entendimento de que a imunidade poderia abranger outros tipos de obras, além das musicais ou literomusicais. No entanto, essa não é a melhor interpretação do preceito.

Isso porque a expressão "obras em geral" deve ser entendida no contexto do dispositivo constitucional. E esse dispositivo prevê, antes de tudo, que a imunidade só pode ser aplicada aos fonogramas e videofonogramas musicais. Logo, "obras em geral” só podem ser aquelas fixadas em fonogramas e videofonogramas musicais e, pois, relativas a música.

A Constituição também estabelece que as obras imunes devem ser produzidas no Brasil e devem possuir autoria brasileira ou ser interpretadas por artistas brasileiros.

Nesse ponto, a técnica de redação adotada pelo constituinte no preceito em comento não foi precisa e certamente suscitará muitas controvérsias. A título de exemplo, o que designaria a expressão "produzidos no Brasil"? Sabe-se que, atualmente, muitas obras musicais e literomusicais são produzidas em vários lugares ao mesmo tempo, sendo possível, por exemplo, que algumas das faixas de um CD sejam produzidas no Brasil e outras sejam produzidas no exterior. Nesse caso, a obra estaria protegida pela imunidade tributária?

O dispositivo também faz referência às obras de "autores brasileiros". Nesse caso, se determinada obra tiver mais de um autor e um deles for brasileiro e outro estrangeiro, seria possível invocar a aplicação do benefício? O que falar então da expressão "interpretadas por artistas brasileiros"? Será necessário que todos os intérpretes tenham nacionalidade brasileira, bastará que um deles a tenha ou teremos que fazer uso de um critério de preponderância?

Nenhuma dessas perguntas tem uma resposta clara no dispositivo constitucional. Ao contrário, é possível atribuir inúmeras interpretações a esse preceito, em sentidos radicalmente diversos, o que certamente gerará sérias dificuldades na aplicação da imunidade.

Sendo reconhecida a constitucionalidade do dispositivo em questão, que, como veremos, pode ser contestada em diversos pontos, entendemos que este deve ser interpretado como a abranger todas as obras que tenham sido produzidas no país (ainda que apenas parcialmente) e que contenham ao menos uma faixa de autoria brasileira ou interpretada por artistas brasileiros. Isso porque a Constituição não determina que toda a obra tenha de ser produzida no país ou que todos os autores ou intérpretes sejam de nacionalidade brasileira. Ademais, o reconhecimento da imunidade em tais casos também estará de acordo com o

\footnotetext{
${ }^{311}$ FERREIRA, Aurélio Buarque de Holanda. Dicionário Aurélio da Língua Portuguesa, p. 1277.
} 
objetivo visado na instituição do preceito, já que também fomentará a indústria nacional e facilitará a divulgação de obras referentes à cultura brasileira para a população do país. 


\subsection{Atividades Abrangidas pela Imunidade.}

Assim como ocorre com a imunidade dos livros, jornais e periódicos, a Constituição brasileira, ao estabelecer a imunidade do art. 150, VI, "e", faz referência ao produto acabado, isto é, aos fonogramas e videofonogramas e aos respectivos suportes.

Com isso, cabe questionar quais seriam as atividades abrangidas pela exoneração tributária. É dizer, deve-se verificar se está imune apenas a comercialização de tais obras ou também as atividades envolvidas no processo de fabricação dos produtos em questão.

Isso porque os fonogramas e videofonogramas também passam por um longo processo de criação, que inclui o aluguel de estúdios, a mixagem de sons, a masterização, a confecção de CDs e DVDs, dentre outras etapas, as quais dependerão em grande parte do tipo de obra em questão e da forma como será fixada em um suporte e veiculada ao consumidor.

Considerando que a Constituição faz referência de forma ampla aos fonogramas e videofonogramas, sem restringir expressamente o benefício à comercialização do produto acabado, entendemos que todas as atividades relativas a esses bens, incluindo as fases de produção e a posterior comercialização, estão, a princípio, abrangidas pela imunidade.

Corrobora essa tese a ressalva contida ao final do dispositivo, que afasta a desoneração na etapa de replicação industrial de mídias ópticas de leitura a laser. De fato, se apenas a fase de comercialização estivesse abarcada pela imunidade tributária, seria totalmente desnecessário fazer semelhante ressalva, de onde se conclui que não só a comercialização dos produtos, como também as etapas de fabricação, estão imunizadas.

Nesse ponto, é importante salientar que a fase de replicação foi excluída do benefício tributário com o objetivo de proteger as empresas situadas na Zona Franca de Manaus. Isso porque várias indústrias instalaram-se naquela região com o objetivo de usufruir de incentivos tributários e muitas delas estão voltadas para a produção de obras musicais.

Assim, ao negar a imunidade à fase de replicação, buscou o constituinte garantir que as empresas da Zona Franca ainda teriam uma vantagem competitiva frente às demais empresas situadas em outras regiões do país. Essa informação consta, inclusive, do Parecer elaborado pela Comissão de Constituição e Justiça do Senado acerca da emenda constitucional, na qual o Senador Eunício Oliveira afirma que "a parte final da alínea que se busca incluir no art. 150, VI, da CF, resguarda a produção industrial de CDs e DVDs na Zona 
Franca de Manaus, com a manutenção da exclusividade do benefício fiscal atualmente concedido na etapa de replicação às indústrias localizadas naquela região"312.

Por essas razões, foi excluída da desoneração tributária a etapa de replicação industrial de mídias ópticas de leitura a laser, a qual designa o processo industrial pelo qual é feita a multiplicação da matriz da obra em inúmeras cópias em CDs, DVDs etc. Vale frisar que está compreendida na ressalva constitucional apenas a replicação de mídias de leitura a laser, de modo que, caso sejam utilizados outros suportes que não se enquadrem nessa descrição (como, por exemplo, os discos de vinil), a imunidade deverá ser aplicada.

Nesse aspecto, a Constituição brasileira foi bastante específica, fazendo referência a um tipo particular de tecnologia. Tal procedimento é criticável e traduz um preciosismo desnecessário por parte do legislador constituinte, uma vez que a tendência é de que as mídias de leitura a laser sejam progressivamente substituídas por outras mais avançadas, o que fará com que o dispositivo constitucional se torne anacrônico em pouquíssimo tempo.

312 Disponível no endereço: http://legis.senado.leg.br/mateweb/arquivos/mate-pdf/107823.pdf. 


\subsection{Inconstitucionalidade do Art. 150, VI, "e".}

Embora o art. 150, VI, "e" tenha sido inserido apenas recentemente na Constituição brasileira, muitos autores já têm suscitado a inconstitucionalidade do dispositivo.

O principal argumento utilizado é o de que a concessão do benefício apenas aos fonogramas e videofonogramas produzidos no Brasil que contenham obras de autores brasileiros ou sejam interpretadas por artistas brasileiros seria um privilégio injustificável, eis que faria uso de um critério de discrímen ilegítimo, violando assim o princípio da igualdade.

De início, cumpre salientar que as normas inseridas no ordenamento por meio de emenda constitucional também estão sujeitas ao controle de constitucionalidade ${ }^{313}$. Sob o aspecto formal, é necessário verificar se a edição da emenda observou os procedimentos legislativos previstos pela Constituição e, sob o aspecto material, deve-se analisar se a disciplina nela trazida não viola as cláusulas pétreas estabelecidas pelo Texto Constitucional, isto é, a forma federativa de Estado, o voto direto, secreto, universal e periódico, a separação dos Poderes e os direitos e garantias individuais, como predica o art. 60.

\subsubsection{Inconstitucionalidade por violação à igualdade.}

Como visto acima, alegam alguns autores que a Emenda Constitucional $\mathrm{n}^{\circ}$ 75/2013 padeceria de inconstitucionalidade material, tendo em vista que teria utilizado critérios inadmissíveis de diferenciação entre os contribuintes para fins de concessão da desoneração tributária, violando assim o princípio da igualdade, que é uma cláusula pétrea.

$\mathrm{O}$ princípio da igualdade determina que duas ou mais pessoas que estejam em situação equivalente devam receber o mesmo tratamento jurídico. Ocorre que, para determinar se tais pessoas são iguais, é necessário antes estabelecer um critério de comparação entre elas.

Isso porque a igualdade é sempre uma relação entre dois sujeitos em função de determinado critério. Com efeito, duas pessoas podem ser iguais em relação a um aspecto (como sexo ou idade) e diferentes quanto a outros (como profissão ou capacidade econômica).

Sendo assim, o exame da relação de igualdade exige, antes de tudo, que se estabeleça quem são os sujeitos objeto da comparação e que se eleja qual será a medida de

\footnotetext{
${ }^{313}$ Esse é também o entendimento pacífico do STF, como se constata dos seguintes julgados: ADI $\mathrm{n}^{\circ}$ 830/DF, Pleno, Rel. Ministro MOREIRA ALVES, DJ 16.09.1994; ADI nº 939/DF, Pleno, Rel. Ministro SYDNEY SANCHES, DJ 18.03.1994; ADI nº 2.356 MC/DF, Pleno, Rel. p/ acórdão Ministro AYRES BRITTO, DJe 18.05.2011.
} 
comparação adotada. Frise-se que tal medida não pode ser escolhida livremente pelo legislador, eis que ela deve se basear em uma diferença real entre os sujeitos e, principalmente, deve ser adequada para atingir a finalidade perseguida pela norma jurídica. Isto é, a medida de comparação deve ser pertinente à finalidade que justificou a sua utilização.

Por fim, é necessário que a finalidade perseguida pela norma (e que, portanto, serviu de fundamento para fixação da medida de comparação) esteja em conformidade com o sistema constitucional em que se insere o dispositivo em questão. Com efeito, a Constituição prevê em seu texto diversos objetivos que devem ser atingidos, de modo que a finalidade escolhida pela norma deve estar em consonância com tais objetivos constitucionais ${ }^{314}$.

Pois bem. O art. 150, VI, "e" faz uso de três critérios para a concessão do benefício: (i) que os fonogramas e videofonogramas sejam produzidos no Brasil; (ii) que as obras sejam de autores brasileiros; e/ou (iii) que sejam interpretadas por artistas brasileiros.

Quanto ao primeiro critério, trata-se de uma tentativa de favorecer a indústria nacional brasileira relativamente aos empreendimentos estrangeiros. Já foi dito nos itens anteriores que tal propósito protecionista não está totalmente alinhado com a tendência atual das Constituições brasileiras, que têm afastado benefícios voltados ao produtor nacional. Ademais, o critério não é inteiramente desejável, eis que acaba por excluir da imunidade tributária obras relativas à música brasileira unicamente em virtude da circunstância de terem sido produzidas no exterior. No entanto, embora o critério não seja desejável, isso não basta para predicar a inconstitucionalidade do dispositivo. De fato, a opção pelo protecionismo é uma decisão eminentemente política a ser tomada pelo constituinte. Desse modo, pode ser alterada apenas pela via da revisão constitucional, e não pelo controle de constitucionalidade.

Ademais, não há que se falar em violação ao princípio da igualdade, já que o critério adotado (produção local) é legítimo para distinguir os contribuintes beneficiados pela desoneração tributária e também é adequado para que sejam alcançados os objetivos visados pela imunidade, que incluem o fortalecimento e a promoção da indústria nacional brasileira.

Critério semelhante é atualmente utilizado em outros benefícios tributários criados pela legislação infraconstitucional, como o Programa de Incentivo à Inovação Tecnológica e Adensamento da Cadeia Produtiva de Veículos Automotores - INOVAR-AUTO. Conforme dispõem os arts. 40 a 44 da Lei $n^{\circ} 12.715 / 2012$, referido programa volta-se à concessão de benefícios relativos ao IPI às empresas que produzam e comercializem dentro do país os veículos classificados nas posições 87.01 a 87.06 da tabela de incidência do imposto.

314 Para um exame detalhado da igualdade em matéria tributária vale conferir: ÁVILA, Humberto. Teoria da Igualdade Tributária. $2^{\mathrm{a}}$ ed. São Paulo: Malheiros, 2009. 
Por outro lado, a utilização desse critério pode ser contestada em face dos tratados internacionais firmados pelo Brasil, como, por exemplo, o Acordo sobre Aspectos dos Direitos de Propriedade Intelectual Relacionados ao Comércio - TRIPS, na medida em que o dispositivo constitucional que prescreve a imunidade confere às empresas brasileiras um tratamento tributário privilegiado frente aos seus concorrentes estrangeiros.

O segundo critério de diferenciação utilizado para a concessão da imunidade tributária é o de que as obras musicais ou literomusicais sejam de autores brasileiros. $\mathrm{O}$ critério em tela também é legítimo e adequado às finalidades visadas pela desoneração tributária, eis que favorece as obras que promovam a cultura brasileira, facilitando assim a difusão da cultura nacional, em linha com o programa estabelecido pelo art. 215 da Carta.

Por fim, cumpre analisar o último requisito fixado pelo dispositivo constitucional.

Prescreve o art. 150, VI, "e" que serão beneficiadas não apenas as obras de autores brasileiros como também as obras interpretadas por artistas brasileiros. Aqui nos parece que há de fato uma violação ao princípio da igualdade, eis que o critério de distinção não é adequado para alcançar qualquer um dos objetivos buscados pela imunidade tributária.

Com efeito, a mera circunstância de o intérprete possuir nacionalidade brasileira não basta para fomentar a cultura nacional ou facilitar a sua divulgação à sociedade. Basta imaginar a hipótese de uma música de autoria de um compositor estrangeiro e que seja gravada por um artista brasileiro dentro do território do nosso país. Que tipo de contribuição tal música poderia trazer para o acesso às fontes de cultura nacional a que aduz o art. 215 ?

No entanto, poder-se-ia argumentar que a função da imunidade tributária deveria ser a de facilitar o acesso a todo tipo de obra musical ou literomusical, eis que todas elas contribuem para a formação cultural do cidadão, independentemente da sua origem.

E, de fato, tal função seria mais desejável.

No entanto, não foi esse o objetivo que inspirou a imunidade do art. 150, VI, “e”. Fosse assim, e não haveria qualquer razão para a referência às obras de autores brasileiros. Bastaria que o dispositivo estabelecesse que todos os fonogramas e videofonogramas que contenham obras musicais ou literomusicais estão alcançados pela imunidade tributária.

Contudo, não foi essa a redação adotada pelo constituinte.

Vale ressaltar que a função da imunidade não pode ser aquela querida pelo intérprete, mas deve ser aquela que pode ser efetivamente construída a partir do preceito que a veicula, conjugado com outras normas constitucionais que com ele se relacionam. 
O preceito do art. 150, VI, "e" não autoriza a conclusão de que a função da desoneração seja a de favorecer toda espécie de obra musical ou literomusical, mas sim apenas aquelas que possam colaborar para a difusão da cultural nacional. Nesse contexto, a utilização de um critério de diferenciação que desconsidera a autoria da obra, levando em conta apenas o seu intérprete, não é adequada para a consecução de tal objetivo. Por esse motivo, entendemos que a referência feita às "obras em geral interpretadas por artistas brasileiros" padece de inconstitucionalidade material, por ofensa ao princípio da igualdade.

\subsubsection{Inconstitucionalidade por ofensa ao regime tributário concedido à} Zona Franca de Manaus.

Argumenta-se também que a Emenda Constitucional n $75 / 2013$ padeceria de inconstitucionalidade por ofensa ao regime tributário concedido à Zona Franca de Manaus.

Tal discussão, inclusive, já foi levada ao Supremo Tribunal Federal por meio da ADI $n^{\circ}$ 5.058/DF, proposta pelo Governador do Estado do Amazonas. Nesta ação, argumentase que a política de incentivo setorial trazida pela emenda em testilha provocaria um drástico esvaziamento do modelo de estímulo regional representado pela Zona Franca de Manaus, violando assim os arts. $5^{\circ}$, XXXVI, e 150, I, da Constituição e os arts. 40 e 92 do ADCT.

É importante salientar que muitas empresas instalaram-se na Zona Franca justamente com o objetivo de fruir dos benefícios tributários outorgados a essa região e, assim, conseguirem atuar de forma competitiva em relação às empresas de outras partes do Brasil. Sabe-se que a instalação na região da Zona Franca implica altos custos logísticos, de modo que a desoneração funciona como uma forma de compensação por esses custos.

Assim, argumentam, caso a desoneração seja ampliada para as empresas instaladas em todo o Brasil, as empresas da ZFM perderão sua condição de competitividade.

Já foi visto que a imunidade foi afastada na etapa de replicação industrial de mídias de leitura a laser exatamente com o objetivo de proteger as empresas situadas na Zona Franca. Porém, de acordo com o autor da ADI n ${ }^{\circ}$ 5.058/DF, tal ressalva seria insuficiente, eis que o custo envolvido nessa etapa seria o menos representativo na composição do preço final do produto. Sendo assim, assegurar apenas essa vantagem não teria o condão de compensar os custos envolvidos com a logística da comercialização para os grandes centros consumidores.

Argumenta-se também que a vantagem das empresas da Zona Franca estaria na fase da comercialização dos produtos, que sofriam pesada tributação antes do advento da 
emenda constitucional. Isso porque grande parte do preço final dos fonogramas e dos videofonogramas seria composta pela margem de lucro das gravadoras e pelos direitos autorais, custos estes que são acrescidos ao custo do produto após a fase de industrialização.

Entretanto, não há que se falar na inconstitucionalidade em tela.

Isso porque os arts. 40, 92 e 92-A do Ato das Disposições Constitucionais Transitórias garantem apenas a manutenção da Zona Franca de Manaus com as suas características de área livre de comércio, de exportação e importação e de incentivos fiscais.

Assim, tais dispositivos não impedem que sejam alterados alguns dos incentivos concedidos à região e muito menos vedam a criação de incentivos setoriais (tais quais as imunidades) que possam de alguma forma impactar as empresas situadas na área incentivada.

Basta lembrar que todas as imunidades tributárias previstas no art. 150, VI, podem vir a influenciar, de uma forma ou de outra, a carga tributária das empresas situadas na região.

Ademais, os benefícios trazidos pela Emenda Constitucional no 75/2013 não têm o condão de eliminar a vantagem competitiva das empresas situadas na Zona Franca, tendo em vista que foi ressalvada da imunidade a etapa de replicação industrial de mídias de leitura a laser, e a desoneração alcançará apenas os impostos, ao passo que as empresas situadas na ZFM são beneficiadas por incentivos que alcançam também outras espécies tributárias.

Diante do exposto, não há que se falar em inconstitucionalidade material do art. 150, VI, "e”, da Carta por ofensa ao regime tributário concedido à Zona Franca de Manaus. 


\section{CONCLUSÃO}

O presente trabalho examinou a interpretação das imunidades tributárias previstas no art. 150, VI, da Constituição Federal de 1988, as quais incluem a imunidade recíproca e as imunidades dos templos de qualquer culto, dos partidos políticos, das entidades sindicais dos trabalhadores, das instituições de educação e de assistência social, dos livros, jornais e periódicos e do papel destinado à sua impressão e dos fonogramas e videofonogramas.

Nesse estudo, definiu-se em primeiro lugar o conceito de interpretação jurídica aqui adotado, entendido como um processo de construção do sentido do texto, e não como mero ato de desvelamento ou extração de um sentido já imanente aos preceitos normativos.

Também foi afirmado que a construção do sentido não é uma atividade totalmente livre, já que a interpretação jurídica está limitada, em primeiro lugar, pelo sentido literal possível do texto. A expressão "sentido literal possível” foi empregada na acepção que lhe dá KARL LARENZ, para quem, dentro do sentido possível, é possível distinguir o "âmbito nuclear" dos termos e os fenômenos situados na sua "franja marginal”, os quais no uso linguístico geral são só algumas vezes considerados. Nesse contexto, afirmou-se que a interpretação que supera o sentido possível não é verdadeira interpretação, mas desenvolvimento do Direito.

Também foi sustentado que, no âmbito do sentido possível, o aplicador não está livre para escolher arbitrariamente qualquer um dos sentidos, de acordo com a sua vontade.

Com efeito, a Ciência do Direito deve fornecer critérios para o controle das decisões judiciais, que não podem ser consideradas mero ato de vontade, sujeito ao arbítrio do julgador. Tendo em vista que tais critérios não podem ser fornecidos integralmente pelo texto, que, como visto, não possui um conteúdo imanente, é necessário controlar a interpretação jurídica por meio da análise do discurso argumentativo adotado pelos aplicadores do Direito.

Nesse discurso, podem ser considerados diferentes argumentos, que levam em conta fatores como as circunstâncias históricas que deram origem à edição da lei a ser interpretada, a relação de uma regra jurídica com outras normas inseridas no ordenamento, os fins visados pela norma e as consequências políticas ou econômicas de determinada decisão.

No entanto, no ordenamento jurídico brasileiro, têm primazia os argumentos de natureza linguística e sistemática, tendo em vista que se referem diretamente à ordem jurídica vigente. $\mathrm{E}$, dentre os argumentos sistemáticos, deve-se prestigiar aquele sentido que seja mais consentâneo com o princípio constitucional subjacente ao dispositivo a ser interpretado. 
As mesmas conclusões se aplicam às normas de Direito Tributário, já que elas estão sujeitas aos mesmos métodos de interpretação aplicáveis às demais normas jurídicas.

Deve-se frisar, no entanto, que as normas que estabelecem a incidência dos tributos, dispondo sobre os seus elementos essenciais, como fato gerador e base de cálculo, assim como as normas que afastam tal incidência, devem ser interpretadas nos limites do sentido literal possível, sendo inadmissível o emprego da analogia ou da redução teleológica.

O mesmo vale para os preceitos que fixam a competência tributária, eis que a Constituição trouxe uma rígida discriminação das competências atribuídas a cada ente federado. Esse entendimento aplica-se não apenas às regras que concedem poder tributário, mas também às regras que veiculam imunidades tributárias, visto que elas são o verso e o reverso da mesma medalha e atuam conjuntamente no desenho das competências tributárias.

Sendo assim, na aplicação das imunidades, devem ser considerados em primeiro lugar os argumentos linguísticos, que limitarão a interpretação ao sentido possível do texto.

No entanto, tais argumentos muitas vezes não serão suficientes para definir a aplicação desses preceitos, visto que a redação adotada pelo Texto Constitucional não trouxe muitos detalhes sobre a matéria. Assim, ganham destaque os argumentos sistemáticos, que estudam a relação das imunidades com as outras normas inseridas no ordenamento pátrio.

Com efeito, o estudo das imunidades não pode ignorar a sua relação com os princípios constitucionais. Isso é especialmente verdadeiro para as imunidades previstas no art. 150, VI, da Constituição, que estão associadas a proteção de diversos princípios, como a liberdade religiosa, a livre manifestação do pensamento, o princípio federativo, dentre outros.

Assim, é necessário examinar a função exercida pelas imunidades no que tange a tais princípios, já que as normas de vedação do art. 150, VI, podem exercer não apenas a função de bloqueio do tributo, como também a função de programa, voltando-se à realização de certos objetivos, e de resguardo, assegurando uma conduta desejada pelo Estado.

Desse modo, a análise da relação entre as imunidades tributárias e os princípios constitucionais não pode ser feita apenas no plano conceitual, mas deve também ser realizada no plano da eficácia. Com efeito, se as imunidades colaboram para a realização de determinadas finalidades prestigiadas pela Constituição, resta evidente que sua interpretação deve analisar se esses objetivos estão sendo concretamente realizados e se tal efetivação tem impactado negativamente a realização de outros valores prezados pela Carta.

A necessidade de uma análise da eficácia das regras de imunidade tributária também tem sido sentida pela jurisprudência, que tem buscado cada mais vez mais analisar os 
efeitos concretos do reconhecimento da imunidade, tendo em vista as características da pessoa beneficiada pela desoneração, bem como as peculiaridades do mercado em que ela opera.

No caso da imunidade recíproca, a desoneração poderá alcançar não apenas os entes federados, como também as autarquias, empresas públicas e sociedades de economia mista, quando atuarem como suas instrumentalidades na prestação de serviços públicos.

Contudo, a imunidade não poderá ser aplicada a toda e qualquer atividade.

A imunidade poderá alcançar os serviços públicos prestados por essas entidades. Mas faz-se necessário verificar se tais serviços são prestados em regime de exclusividade ou em regime de concorrência com as empresas privadas. Caso haja concorrência, a imunidade só pode ser reconhecida se não gerar distorções graves à livre concorrência, uma vez que a tributação (e, consequentemente, a desoneração) também deve se pautar pela neutralidade.

Por outro lado, a princípio, a imunidade recíproca não deve alcançar as atividades econômicas exercidas por estas entidades, eis que tais atividades configuram manifestações de capacidade contributiva e a desoneração não pode ter como objetivo favorecer o aumento patrimonial dos particulares ou do Estado ou provocar uma concorrência desleal no mercado.

Contudo, caso se verifique que as atividades econômicas realizadas pelas instrumentalidades do Estado têm caráter marginal, não podem gerar prejuízos à concorrência e as receitas com elas obtidas são integralmente voltadas ao custeamento de serviços públicos, a imunidade recíproca deve ser aplicada também a tais casos, sob pena de desfalcar o patrimônio e as rendas voltadas a consecução de fins perseguidos pelo Estado.

O mesmo critério deve ser aplicado às instituições de educação e de assistência social. Isto é, a imunidade tributária deve alcançar apenas os serviços assistenciais e educacionais exercidos por essas instituições e só poderá ser aplicada a atividades econômicas quando tais atividades forem exercidas em caráter apenas marginal e as rendas com elas obtidas forem integralmente utilizadas para custear a prestação dos serviços públicos.

Por sua vez, quanto às entidades religiosas, a imunidade não deve ser reconhecida para qualquer atividade comercial, ainda que os recursos sejam aplicados nos fins do culto, eis que a desoneração aqui não opera como estímulo ou fomento das práticas religiosas, mas apenas como forma de protegê-las de pressões exercidas pelo Estado através da tributação.

Quanto à imunidade dos livros, jornais e periódicos, ela deverá abranger "todos os impressos ou gravados, por quaisquer processos tecnológicos, que transmitam aquelas ideias, informações, comentários, narrações reais ou fictícias sobre todos os interesses humanos, por meio de caracteres alfabéticos ou por imagens e, ainda, por signos Braile destinados a cegos". 
Assim, não pode ser feita qualquer restrição relativa ao conteúdo das publicações ou mesmo ao suporte em que elas são veiculadas, abrangendo inclusive os livros eletrônicos.

Ademais, a imunidade em tela deve alcançar não apenas os produtos em sua fase de comercialização, mas todas as etapas inerentes à confecção de livros, jornais e periódicos, incluindo também os serviços de redação, editoração, composição, correção e revisão da obra.

Por sua vez, a imunidade concedida ao papel deve abranger apenas os papeis utilizados na confecção de livros, jornais e periódicos e os insumos a eles assimiláveis, não tendo o condão de alcançar outros insumos ou bens do ativo fixo empregados na produção.

Por fim, a imunidade dos fonogramas e dos videofonogramas musicais abrangerá o registro exclusivamente sonoro e o registro de sons e imagens relativos a obras musicais ou literomusicais, e os respectivos suportes materiais e os arquivos digitais que os contenham.

Frise-se que tal imunidade pode alcançar apenas as obras produzidas no Brasil e que tenham autoria brasileira ou sejam interpretadas por artistas brasileiros, embora a inconstitucionalidade desse último requisito possa ser defendida por violação à igualdade.

Sendo reconhecida a constitucionalidade do preceito em questão, este deve ser interpretado como a abranger todos os fonogramas e os videofonogramas musicais que contenham obras produzidas no país (ainda que a produção aqui tenha sido apenas parcial) e que possuam ao menos uma faixa de autoria brasileira ou interpretada por artistas brasileiros.

Ademais, a imunidade deverá alcançar tais objetos não apenas em sua fase de comercialização, mas também em todas as etapas necessárias à confecção desses produtos, ressalva feita à etapa de replicação industrial de mídias ópticas de leitura a laser, cuja desoneração tributária foi expressamente afastada pelo art. 150, VI, “e”, da Constituição. 


\section{BIBLIOGRAFIA}

ANDRADE, José Maria Arruda de. Interpretação da Norma Tributária. São Paulo: MP Editora, 2006.

ARAÚJO, Petrônio Baptista. Impôsto sôbre a Transmissão da Propriedade: trabalho realizado para o Instituto de Direito Público e Ciência Política. Rio de Janeiro: FGV, 1954.

ASCARELLI, Tullio, SOUSA, Rubens Gomes de, e ALMEIDA FILHO, João Batista Pereira de. Lucros Extraordinários e Imposto de Renda: comentários ao decreto n. 15028 de 13 de março de 1944, em relação com a doutrina e a legislação do imposto de renda. São Paulo: Livraria Martins, 1944.

ATALIBA, Geraldo. Natureza Jurídica da Contribuição de Melhoria. São Paulo: Revista dos Tribunais, 1964.

Sistema Constitucional Tributário Brasileiro. São Paulo: Revista dos

Tribunais, 1968.

- Venda de Minérios - Faturamento - PIS. Revista de Direito Administrativo, nº 196, pp. 305-320, 1994.

ATALIBA, Geraldo e BARRETO, Aires Fernandino. Imposto sobre Serviços. Tributação de anúncios e destaques em listas ou guias telefônicos. Inadmissibilidade em face de vedação constitucional. Revista de Direito Tributário, v. 11, nº 39, pp. 105-121, 1987. 
ÁVILA, Humberto. Argumentação Jurídica e a Imunidade do Livro Eletrônico. Revista Diálogo Jurídico, Ano I, vol. I, nº 5, 2001.

- Função da Ciência do Direito Tributário: do Formalismo Epistemológico ao Estruturalismo Argumentativo. Revista Direito Tributário Atual, v. 29, pp. 181-204, 2013. . Sistema Constitucional Tributário. $5^{\mathrm{a}}$ ed. São Paulo: Saraiva, 2012. Teoria da Igualdade Tributária. $2^{\mathrm{a}}$ ed. São Paulo: Malheiros, 2009. Teoria dos Princípios: da definição à aplicação dos princípios jurídicos. $5^{\text {a }}$ ed. São Paulo: Malheiros, 2006.

BALEEIRO, Aliomar. Direito Tributário Brasileiro. 12 ${ }^{\mathrm{a}}$ ed. Rio de Janeiro: Forense, 2013. Imunidade e Isenções Tributárias. Revista de Direito Tributário, v. 1, nº 1, pp. 67-100, 1977. Limitações Constitucionais ao Poder de Tributar. $8^{\text {a }}$ ed. Rio de Janeiro: Forense, 2010. . Uma Introdução à Ciência das Finanças. $17^{\mathrm{a}}$ ed. Rio de Janeiro: Forense, 2010.

BARRETO, Aires Fernandino e BARRETO, Paulo Ayres. Imunidades Tributárias: Limitações Constitucionais ao Poder de Tributar. $2^{a}$ ed. São Paulo: Dialética, 2001.

BECKER, Alfredo Augusto. Teoria Geral do Direito Tributário. $5^{\mathrm{a}}$ ed. São Paulo: Noeses, 2010.

BERLIRI, Antonio. Corso Istituzionale di Diritto Tributario. Milano: A. Giuffrè, 1965.

BOBBIO, Norberto. Teoria do Ordenamento Jurídico. $10^{\mathrm{a}}$ ed. Brasília: Universidade de Brasília, 1999.

BORGES, Souto Maior. Teoria Geral da Isenção Tributária. $3^{\mathrm{a}}$ ed. São Paulo: Malheiros, 2011.

BOTTALO, Eduardo Domingos. Fundamentos do IPI: (imposto sobre produtos industrializados). São Paulo: Revista dos Tribunais, 2002.

CAMPOS, Francisco. Direito Constitucional. Rio de Janeiro: Freitas Bastos, 1956.

CANTO, Gilberto de Ulhôa. A Imunidade Tributária das Entidades Fechadas de Previdência Privada. São Paulo: ABRAPP, 1985. 
Temas de Direito Tributário. Vol. 3. Rio de Janeiro: Alba, 1964.

CANOTILHO, José Joaquim Gomes. Direito Constitucional e Teoria da Constituição. $4^{\mathrm{a}}$ ed. Coimbra: Almedina, 2000.

CARRAZZA, Roque Antonio. A Imunidade Tributária das Empresas Estatais Delegatárias de Serviços Públicos: Um estudo sobre a imunidade tributária da Empresa Brasileira de Correios e Telégrafos - ECT. São Paulo: Malheiros, 2004.

. Curso de Direito Constitucional Tributário. $22^{\mathrm{a}}$ ed. São Paulo:

Malheiros, 2006.

CARVAlHO, Paulo de Barros. Curso de Direito Tributário. $21^{\mathrm{a}}$ ed. São Paulo: Saraiva, 2009.

Direito Tributário: Linguagem e Método. $4^{\mathrm{a}}$ ed. São Paulo: Noeses,

2011.

COÊLHO, Sacha Calmon Navarro. Comentários à Constituição de 1988. $9^{\mathrm{a}}$ ed. Rio de Janeiro: Forense, 2005.

. Curso de Direito Tributário Brasileiro. 9a ed. Rio de Janeiro: Forense, 2007.

COSTA, Regina Helena. Imunidades Tributárias: Teoria e Análise da Jurisprudência do STF. São Paulo: Malheiros, 2001.

COSTA-CORRÊA, André Luiz. A (In)constitucionalidade da Emenda Constitucional n. 75: a Imunidade sobre Fonogramas e Videofonogramas e seus Suportes Materiais ou Arquivos Digitais. Revista Dialética de Direito Tributário no 222, pp. 36-48, 2014.

DENARI, Zelmo. Curso de Direito Tributário. 6a ed. Rio de Janeiro: Forense, 1998. Elementos de Direito Tributário. São Paulo: Juriscredi, 1971.

DERZI, Misabel e COÊLHO, Sacha Calmon Navarro. A Imunidade Intergovernamental Recíproca e sua Extensão às Autarquias Federais. Revista Dialética de Direito Tributário, no 6, pp. 96-114, 1996.

FALCÃO, Amílcar de Araújo. Fato Gerador da Obrigação Tributária. $6^{\mathrm{a}}$ ed. Rio de Janeiro: Forense, 1997.

Imunidade e Isenção Tributária - Instituição de Assistência Social.

Revista de Direito Administrativo, vol. 66, pp. 367-375, 1961. 
Introdução ao Direito Tributário. $6^{\text {a }}$ ed. Rio de Janeiro: Forense, 1999.

FERRAZ JUNIOR, Tércio Sampaio. Introdução ao Estudo do Direito: Técnica, Decisão, Dominação. $4^{\mathrm{a}}$ ed. São Paulo: Atlas, 2003.

Livro Eletrônico e Imunidade Tributária. Revista dos Tribunais -

Cadernos de Tributário e Finanças Públicas, v. 6, nº 22, pp. 32-38, 1998.

FERREIRA FILHO, Manoel Gonçalves. Comentários à Constituição Brasileira. $5^{\mathrm{a}}$ ed. São Paulo: Saraiva, 1984.

Comentários à Constituição Brasileira de 1988. São Paulo: Saraiva, 1994.

FOLLONI, André. Ciência do Direito Tributário no Brasil: Crítica e perspectivas a partir de José Souto Maior Borges. São Paulo: Saraiva, 2013.

FONROUGE, Carlos María Giuliani. Derecho Financeiro. Vol. I. $3^{\text {a }}$ ed. Buenos Aires: Ediciones Depalma, 1977.

FONROUGE, Carlos María Giuliani [et. al.]. Temas de Derecho Tributario. Buenos Aires: Facultad de Ciencias Económicas de la Universidad de Buenos Aires, 1968.

GADAMER, Hans-Georg. Verdade e Método: Traços Fundamentais de uma Hermenêutica Filosófica. Vols. I e II. 12ª ed. Petrópolis: Vozes, 2012.

GIANNINI, Achille Donato. Instituzioni di Diritto Tributario. $7^{\text {a }}$ ed. Milão: A. Giuffrè, 1956. GRIZIOTTI, Benvenuto. Principios de Politica, Derecho y Ciencia de la Hacienda. Tradução para o espanhol de Enrique R Mata. Madri: Reus, 1935.

GUASTINI, Riccardo. Interpretare e Argomentare. Milão: Giuffrè, 2011. Teoria e Dogmatica delle Fonti. Milão: Giuffrè, 1998. Teoria e Ideologia da Interpretação Constitucional. Revista Interesse Público, v. 8, nº 40, pp. 217-256, 2006.

HART, Herbert L. A. O Conceito de Direito. Tradução de Antônio de Oliveira Sette-Câmara. São Paulo: Martins Fontes, 2009.

HORVATH, Estevão. Contribuições de Intervenção no Domínio Econômico. São Paulo: Dialética, 2009.

JARACH, Dino. Curso Superior de Derecho Tributario. Edição nova atualizada. Buenos Aires: Liceo Profesional Cima, 1969. 
Finanzas Públicas y Derecho Tributario. $3^{\mathrm{a}}$ ed. Buenos Aires:

Abeledo-Perrot, 1999.

KELSEN, Hans. Teoria Pura do Direito. São Paulo: Martins Fontes, 2000.

LACOMBE, Américo Lourenço Masset [et. al.]. Estudos Jurídicos em Homenagem a Vicente Ráo. São Paulo: Resenha Universitária, 1976.

LARENZ, Karl. Metodologia da Ciência do Direito. $6^{\mathrm{a}}$ ed. Lisboa: Calouste Gulbenkian, 2012.

LEGAZ Y LACAMBA, Luis. Filosofía del Derecho. Barcelona: Bosch, 1953.

MACHADO, Hugo de Brito. Curso de Direito Tributário. $33^{\mathrm{a}}$ ed. São Paulo: Malheiros, 2012.

MARTINS, Ives Gandra da Silva. Comentários à Constituição do Brasil. Vol. 6. Tomo I. São Paulo: Saraiva, 1990.

Imunidade Constitucional de Publicações (Interpretação Teleológica da Norma Maior - Análise Jurisprudencial). Revista de Direito Tributário, v. 11, nº 41, pp. 221-237,1987.

MARTINS, Ives Gandra da Silva (coord.). Imunidades Tributárias. São Paulo: Revista dos Tribunais: Centro de Extensão Universitária, 1998.

MARSHALL, John. The Constitutional Decisions of John Marshall. Vol. I. Editado por Joseph P. Cotton Jr. Nova Iorque: G.P. Putnam's Sons, 1905.

MAXIMILIANO, Carlos. Hermenêutica e Aplicação do Direito. $19^{\mathrm{a}}$ ed. Rio de Janeiro: Forense, 2001.

MEIRELLES, Hely Lopes. Direito Municipal Brasileiro. 17ª ed. São Paulo: Malheiros, 2013. MIRANDA, Pontes. Comentários à Constituição de 1946. Vol. II. 2a ed. São Paulo: Max Limonad, 1953. Comentários à Constituição de 1967. Tomo II. São Paulo: Revista dos

Tribunais, 1967.

MORAES, Bernardo Ribeiro de. A Imunidade Tributária e seus Novos Aspectos. Revista Dialética de Direito Tributário, nº 34, pp. 19-40, 1998.

Doutrina e Prática do Impôsto de Indústrias e Profissões. Tomo II. São

Paulo: Max Limonad, 1964. 
MORAES, Oswaldo de. A Analogia no Direito Tributário Brasileiro. São Paulo: Revista dos Tribunais, 1965.

MÜLLER, Friedrich. Metodologia do Direito Constitucional. $4^{\mathrm{a}}$ ed. São Paulo: Revista dos Tribunais, 2010.

NASCIMENTO, Carlos Valder do (org.). Interpretação no Direito Tributário. São Paulo: Revista dos Tribunais, 1989.

NEVES, Antonio Castanheira. Interpretação Jurídica, in Digesta, Escritos acerca do Direito, do Pensamento Jurídico, da sua Metodologia e Outros. Vol. 2.. Coimbra: Coimbra Editora, 1995.

NOGUEIRA, Ruy Barbosa. Curso de Direito Tributário. 14ª ed. São Paulo: Saraiva, 1995. Da Interpretação e da Aplicação das Leis Tributárias. $2^{\mathrm{a}}$ ed. São Paulo: Revista dos Tribunais, 1965. Imunidades. $2^{\mathrm{a}}$ ed. São Paulo: Saraiva, 1992.

NOGUEIRA, Ruy Barbosa (org.). Estudos Tributários em Homenagem à Memória de Rubens Gomes de Sousa. São Paulo: Resenha Tributária, 1974.

PINTO, Carlos Alberto A. de Carvalho. Hermenêutica das Leis Fiscais. São Paulo: Prefeitura do Município de São Paulo, 1941.

RODRIGUES, Léda Boechat. A Corte Suprema e o Direito Constitucional Americano. $2^{\mathrm{a}}$ ed. Rio de Janeiro: Civilização Brasileira, 1992.

RUGGIERO, Roberto de. Instituições de Direito Civil. Vol. I. Tradução da $6^{a}$ edição italiana por Paolo Capitanio. Campinas: Bookseller, 1999.

SANTOS, J. M. de Carvalho (org.). Repertório Enciclopédico do Direito Brasileiro. Vol. 29. Rio de Janeiro: Borsoi, 1947.

SARAIVA FILHO, Oswaldo Othon de Pontes. A Imunidade dos Livros, Jornais e Periódicos e do Papel Destinado a sua Impressão. Revista dos Tribunais, Cadernos de Direito Tributário e Finanças Públicas, ano 4, nº 14, 1996.

SCHAUER, Frederick F. Playing by the Rules: A philosophical examination of rule-based decision-making in law and in life. Nova Iorque: Oxford University Press, 2002.

SCHOUERI, Luís Eduardo. Direito Tributário. São Paulo: Saraiva, 2011. 
SELIGMAN, Edwin R. A. The Income Tax: a study of the history, theory and practice of income taxation at home and abroad. Nova Iorque: Macmillan, 1911.

SILVA, José Afonso da Silva. Aplicabilidade das Normas Constitucionais. $8^{\mathrm{a}}$ ed. São Paulo, Malheiros, 2012.

Curso de Direito Constitucional Positivo. 25ª ed. São Paulo: Malheiros,

2005.

SICHES, Luis Recasens. Tratado General de Filosofia del Derecho. 19ª ed. México: Porrúa, 2008 .

SOUSA, Rubens Gomes de. Compêndio de Legislação Tributária. São Paulo: Resenha Tributária, 1975.

SOUSA, Rubens Gomes de. [et. al.]. Interpretação no Direito Tributário. São Paulo: Saraiva, 1975.

TORRES, Heleno Taveira. Direito Constitucional Tributário e Segurança Jurídica: Metódica da Segurança Jurídica do Sistema Constitucional Tributário. São Paulo: Revista dos Tribunais, 2011.

TORRES, Ricardo Lobo. As Influências Italianas no Direito Tributário Brasileiro. Revista de Direito Tributário, no 84, pp. 70-82, 2002.

Normas de Interpretação e Integração do Direito Tributário. $4^{\mathrm{a}}$ ed. Rio de Janeiro: Renovar, 2006.

Tratado de Direito Constitucional Financeiro e Tributário. Vol. III. Os

Direitos Humanos e a Tributação: Imunidades e Isonomia. $3^{\text {a }}$ ed. Rio de Janeiro: Renovar, 2005.

TORRES, Ricardo Lobo (org.). Temas de Interpretação do Direito Tributário. Rio de Janeiro: Renovar, 2003.

VANONI, Ezio. Natureza e Interpretação das Leis Tributárias. Tradução de Rubens Gomes de Sousa. Rio de Janeiro: Edições Financeiras S/A, s/d.

VELLOSO, Andrei Pitten. Analogia e Isonomia no Direito Tributário. Revista Tributária e de Finanças Públicas, v. 13, nº 62, pp. 77-95, 2005.

- Imunidade Tributária do Livro Digital: Fundamentos e Alcance.

Revista de Estudos Tributários nº 83, pp. 21-39, 2012. 
VILLEGAS, Héctor Belisario. Curso de Finanzas, Derecho Financiero y Tributario. $8^{\mathrm{a}}$ ed. Buenos Aires: Astrea, 2002.

XAVIER, Alberto. Os Princípios da Legalidade e da Tipicidade da Tributação. São Paulo: Revista dos Tribunais, 1978.

WITTGENSTEIN, Ludwig. Philosophical Investigations. $4^{\mathrm{a}}$ ed. Tradução de G.E.M. Anscombe, P.M.S. Hacker e Joachim Schulte. Singapura: Blackwell Publishing, 2009. 